UNIVERSIDADE DE SÃO PAULO

PROGRAMA DE PÓS-GRADUAÇÃO EM MEIOS E PROCESSOS AUDIOVISUAIS

VIVIANE VALLADES DA SILVA

KÍNEMA-ÉMATOS + GRÁPHEIN: ESTUDO DAS EXPERIMENTAÇÕES DO DISPOSITIVO CINEMA NO ESPAÇO DAS ARTES VISUAIS. 
VIVIANE VALLADES DA SILVA

\section{KÍNEMA-ÉMATOS + GRÁPHEIN: ESTUDO DAS EXPERIMENTAÇÕES DO DISPOSITIVO CINEMA NO ESPAÇO DAS ARTES VISUAIS.}

Dissertação apresentada ao Programa de Pós-Graduação em Meios e Processos Audiovisuais da Escola de Comunicações e Artes da Universidade de São Paulo para obtenção do título de Mestre em Ciências

Área de Concentração: Poéticas e Técnicas Orientador: Prof. Dr. Almir Antonio Rosa 
Autorizo a reprodução e divulgaçăo total ou parcial deste trabalho, por qualquer meio convencional ou eletrônico, para fins de estudo e pesquisa, desde que citada a fonte.

Catalogaçăo na Publicação

Serviço de Biblioteca e Documentaçăo

Escola de Comunicaçces e Artes da Universidade de Sao Paulo

Dados fornecidos pelo(a) autor(a)

S1lva, Viviane Vallades da

KTUEMA-BNATUS + GRADHEIN = = EETODO DAS EXDERTMFNTACOั̈BS DO

DISPOSITIVO CINEMA WO ESPACO DAS ARTES VISUAIS, / VIVIaIJ

Valladea da silva. ... săo paulo: $\mathrm{V}$. $\forall$. Silva, 2014.

179 pit 11 . + DVD.

Dissertaç̧ŏ (Mestrado) - Dregrama de DSs-Graduaç̄o en Meion - Proceseos Audiovizuaiz - Bscola do Comunicapobez e Artes / Universidade de săo Paulo.

Orientador: Almis Antonio pora

Bibliografia

1. cinema de exponiçâo 2. diepoaitivo 3. tela 4-artea visuai= 5. cinoma expandido. I. Rosa, Almis Antonio II. Trtulo. 
Viviane Vallades da Silva

KÍNEMA-ÉMATOS + GRÁPHEIN: ESTUDO DAS EXPERIMENTAÇÕES DO DISPOSITIVO CINEMA NO ESPAÇO DAS ARTES VISUAIS.

Dissertação apresentada ao Programa de Pós-Graduação em Meios e Processos Audiovisuais da Escola de Comunicações e Artes da Universidade de São Paulo para obtenção do título de Mestre em Ciências Área de Concentração: Poéticas e Técnicas

BANCA EXAMINADORA

Prof. Dr.

Instituição: Assinatura:

Prof. Dr.

Instituição: Assinatura:

Prof. Dr.

Instituição: Assinatura;

Data 


\section{AGRADECIMENTOS}

Ao Prof. Dr. Almir Antonio Rosa, por ter confiado no trabalho e pelo processo todo de orientação.

Agradeço ao Prof. Dr. Arlindo Machado e a Profa. Dra. Rosangella Leote pelas considerações realizadas na banca de qualificação, que muito contribuíram para repensar vários pontos da pesquisa. Aos professores integrantes da banca final de mestrado.

Agradeço as professoras: Profa. Dra. Branca de Oliveira e Profa. Dra. Rosangella Leote que ajudaram bastante durante as aulas que fiz ainda como aluna especial com indicações de livros e assuntos que com certeza reverberaram neste trabalho, assim como me foi muito importante a aula Poéticas e Técnicas da Montagem Audiovisual que realizei na USP sob a orientação de Prof. Dr. Almir Almas, Prof. Dr. Arlindo Machado e Profa. Dra. Maria Dora Genis Mourão.

Ao Philippe Dubois que durante a sua palestra na ECA USP me indicou e me ofereceu alguns de seus textos que contribuíram intensamente para esta pesquisa.

Agradeço também a todos os professores: Prof. Dr. Cristian Borges, Profa. Dra. Patrícia Moran, Prof. Dr. Maurício Cândido Taveira, Profa. Dra. Carmen S. G. Aranha, Profa. Dra. Maria Cristina Machado Freire, pelas aulas, indicações de livros, pelos materiais, filmes e obras apresentadas.

Aos meus pais, Adilson Vallades e Mercedes Espirito, as minhas irmãs, Regina e Shirlei e a minha sobrinha Marina, pela paciência e pela colaboração.

Mercedes Espirito da Silva colaboradora de muitos trabalhos que desenvolvo.

Marcos Nobre pelo apoio, por me ouvir e por estar sempre disposto a ajudar.

Alessandra Bochio, Felipe, Daniela Farias, Gabriela Caetano pelas dicas sobre disciplinas, projetos e sobre a vida acadêmica.

Ricardo Davino e Vinicius Manoel pela amizade.

Ao pessoal da biblioteca e funcionários da USP que sempre nos ajudam, nos momentos mais complicados.

Agradeço também à Maria Stella Valli pela revisão dos textos. 


\title{
RESUMO
}

Nas exposições, galerias de arte, espaço urbano, observamos atualmente a presença de numerosas obras de imagens em movimento projetadas. Estas obras se utilizam em sua construção do dispositivo cinema: projeção, tela, espaço escuro, filmes, mas produzem alterações na forma padrão dominante de apresentação associada a esse dispositivo: espectador sentado, duração imposta de observação de aproximadamente 1 a 2 horas, sala escura, projeção única e frontal sobre uma única tela, apresentada em uma sala com a arquitetura semelhante à do teatro italiano.

A presente pesquisa destina-se a estudar a migração de imagens e do dispositivo cinema, para os espaços de arte e as alterações que estão sendo feitas com esse dispositivo. Essas alterações embora mais intensas atualmente, não são inéditas. Observaremos as modificações realizadas nesse dispositivo e focaremos na tela, através do estudo desse elemento. Para isso, faremos um breve histórico dela, análises e descrições de várias obras, que façam uso da tela de forma diferenciada do padrão, alterando sua quantidade, disposição no espaço, formato e materialidade.

Palavras-chave: cinema de exposição, dispositivo, tela, cinema expandido

\begin{abstract}
Exhibitions, art galleries, urban space, today observed the presence of numerous works of projected images in motion. These works are used in its construction of cinema device: projection screen, dark space, movies, but produce changes in the dominant standard form of presentation associated with this device: spectator sitting, imposed duration of observation of approximately 1 to 2 hours, dark room, and single front projection on a single screen, displayed in a room similar to the Italian theater architecture.

This research intended to study the migration of images and movie device for art spaces and the changes that are being made with this device. These changes although more intense now, are not unprecedented. Observe the changes made to the device, and will focus on the screen, through the study of this element. For this, we will make a brief history of it, analyzes and descriptions of various works, making use of the screen differently from the standard by changing its quantity, disposition space, form and materiality.
\end{abstract}

Keywords: Cinema exposure, device, screen, expanded cinema 


\section{Sumário}

Introdução

Capítulo 1: Tratamentos em telas e expansão de materiais e tecnologias usados no campo das artes visuais

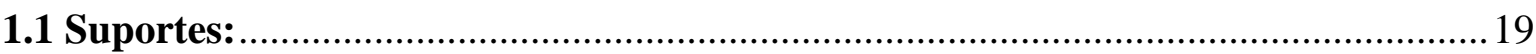

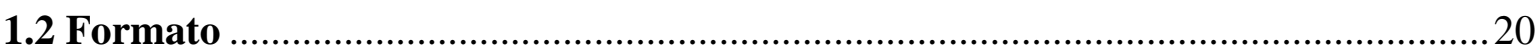

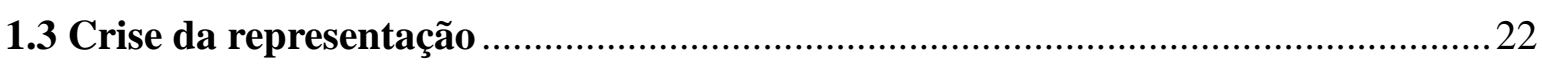

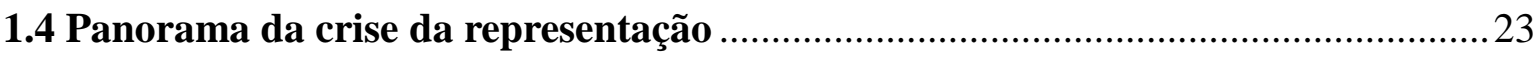

Capítulo 2 Apontamentos nos usos de telas - do pré-cinema ao cinema expandido.......... 30

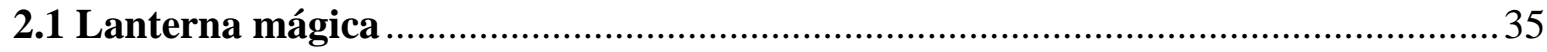

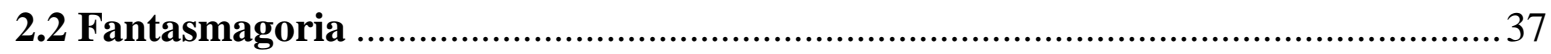

2.3 As telas nos Panorama, Dioramas e brinquedos ópticos ..................................... 42

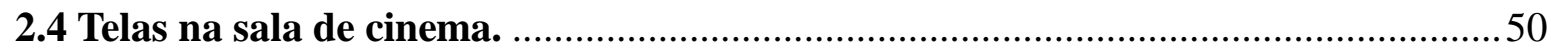

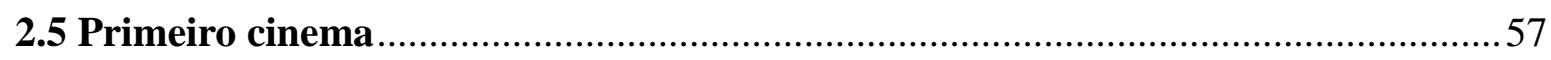

2.6 Cinemas experimentais/ undergroung /avant garde ........................................... 60

2.7 Uso e alterações nas telas em Napoléon (1927) Abel Gance................................... 64

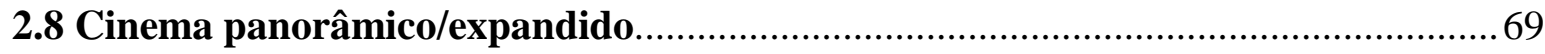

2.9 O corpo como suporte da arte e relações entre corpo e imagens em movimento ... 78

Capítulo 3: Cinema de Exposição .......................................................................................................91

3.1 Percurso das imagens em movimento nos museus. ...........................................91

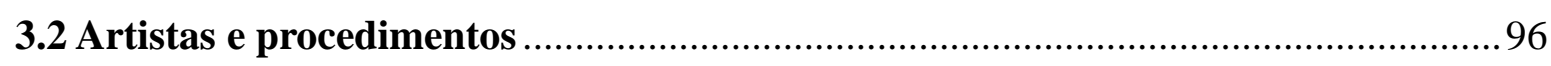

3. 3.1 Experiência de cinema/ Rosângela Rennó / 2004 .............................................. 116

3.3.2 The Influence Machine (2000) / Tony Oursler ......................................................... 122

3.3.3 Cosmococas: Bloco de Experiências in Cosmococa- program in progress/Helio

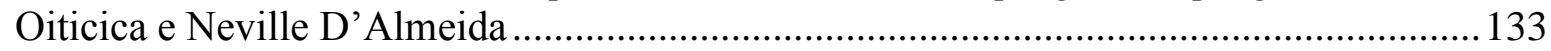

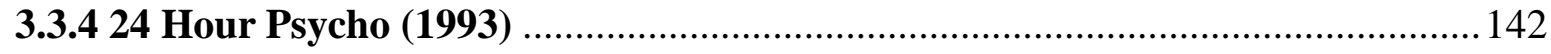

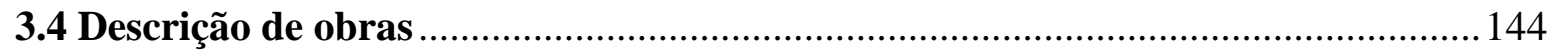

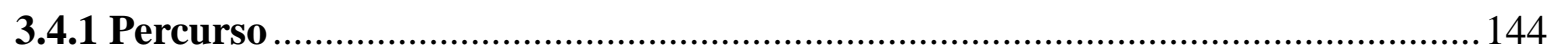

3.4.2 Série: Autorretrato com duração e sons variáveis ......................................... 147

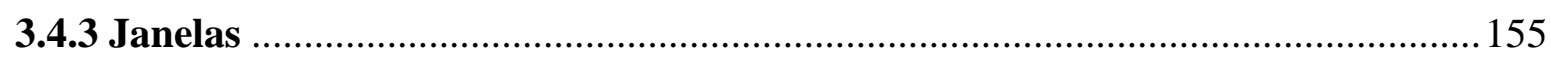

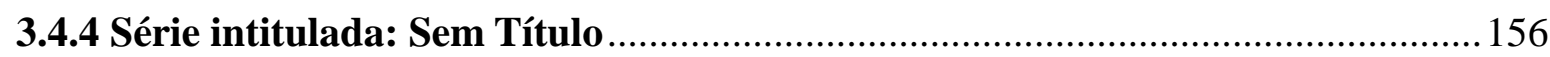

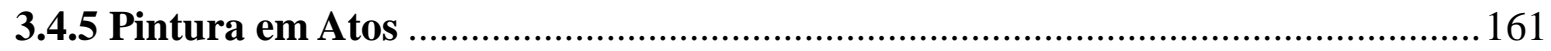

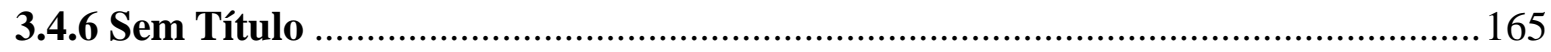

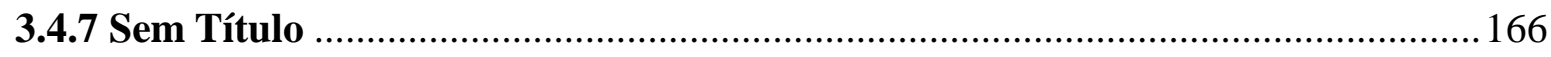

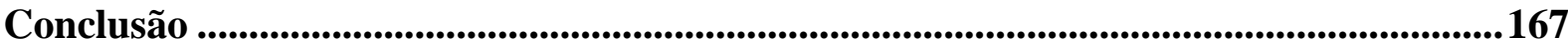

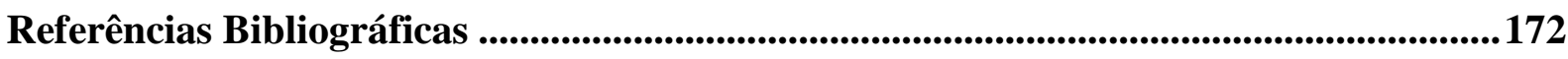

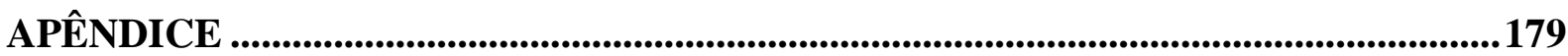


Figura 1: Pablo Picasso. Natureza Morta com Cadeira de Palha, 1912 .................................21

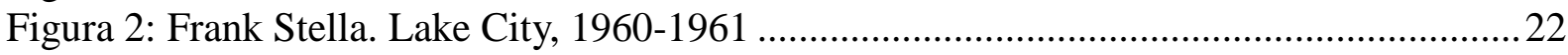

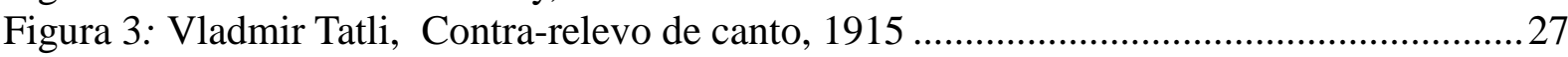

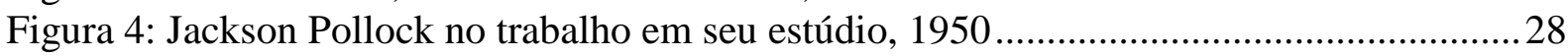

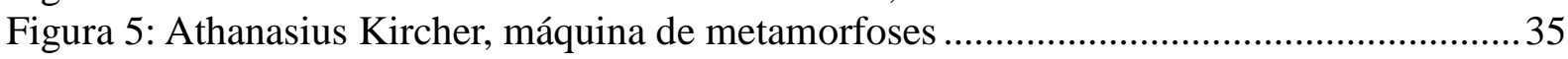

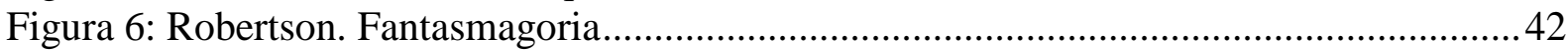

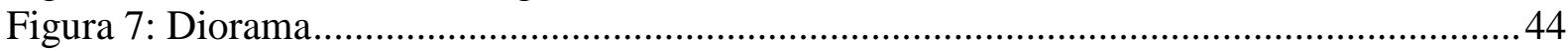

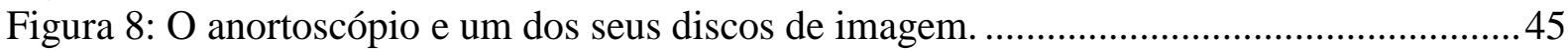

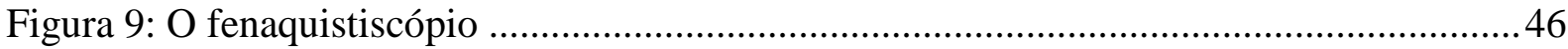

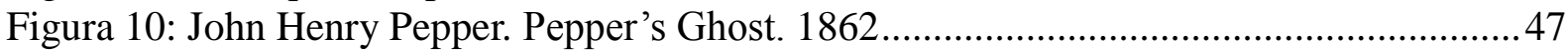

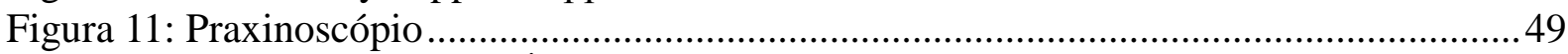

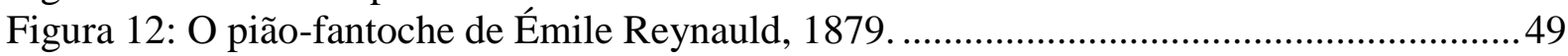

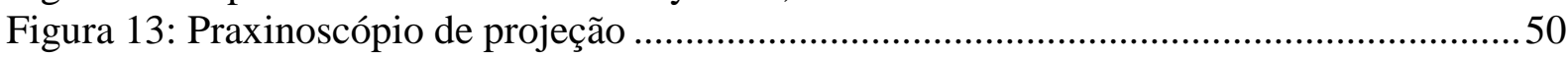

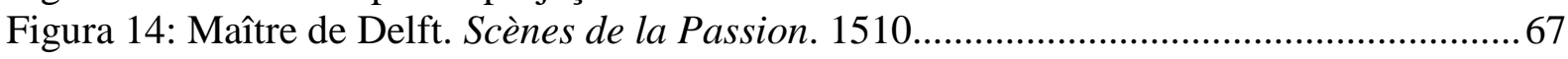

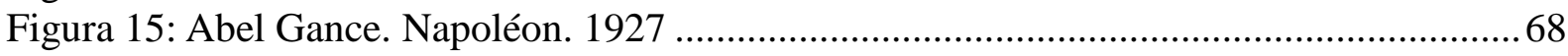

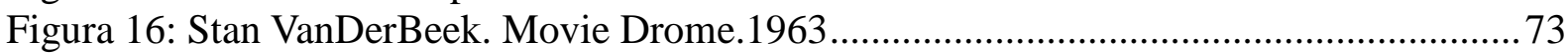

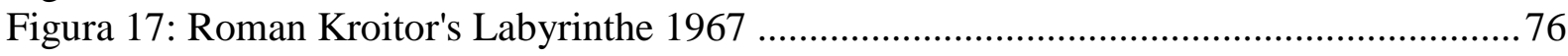

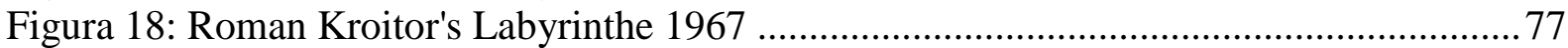

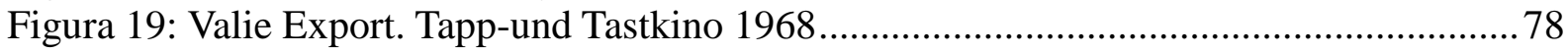

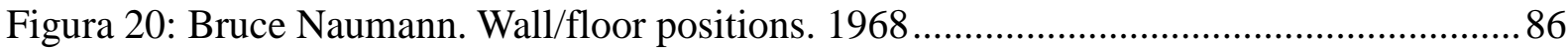

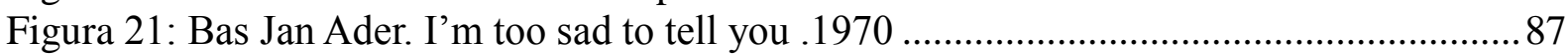

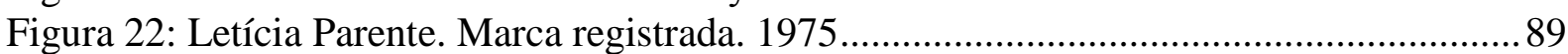

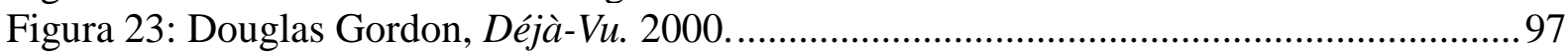

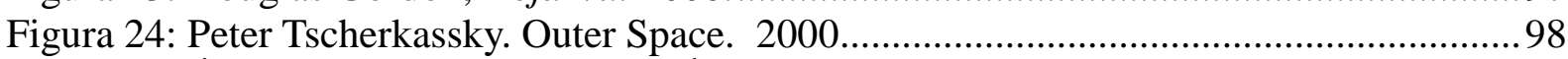

Figura 25: Éric Rondepierre. Les Trente Étreintes/ Os trinta abraços. 1997-1999 .................. 99

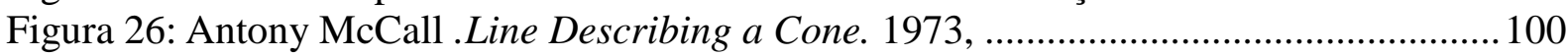

Figura 27: Hiroshi Sugimoto. Radio City Music Hall. 1978 ….............................................. 101

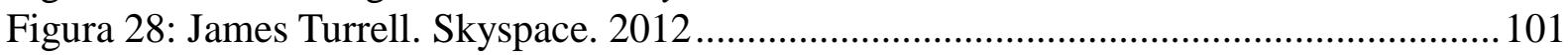

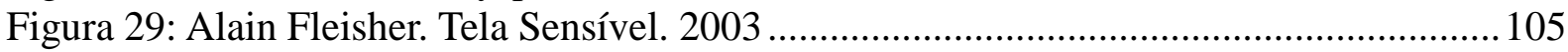

Figura 30: Rosângela Rennó. Experiência de Cinema. 2004-5............................................. 106

Figura 31: Alain Fleisher. Autant en Emporte le Vent (E o Vento Levou), 1980................... 107

Figura 32: Viviane Vallades. Autorretrato com duração e sons variáveis III. 2012 ............... 108

Figura 33: Melick Ohanian, Invisible Film.2005 ............................................................... 109

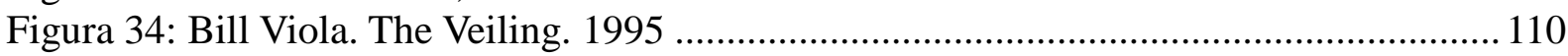

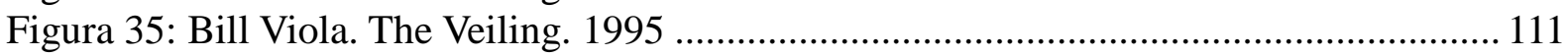

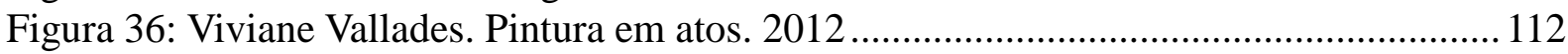

Figura 37: Krzysztof Wodiczko Hiroshima Projection. 1999 ................................................ 114

Figura 38: Thecla Schiphorst. Bodymaps: artifacts of touch ............................................ 115

Figura 39: Rosângela Rennó. Experiência de Cinema 2004-5 …........................................ 122

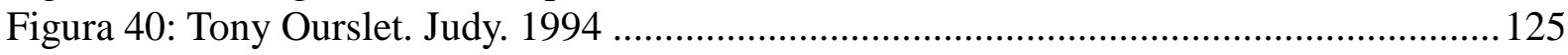

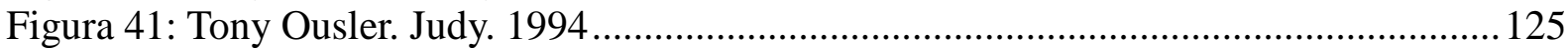

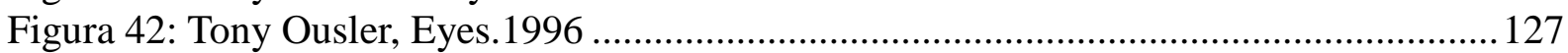

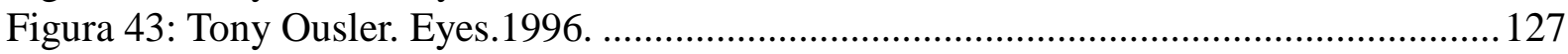

Figura 44: Tony Oursler. Influence Machine. 2000 ............................................................ 132

Figura 45: Tony Oursler. Influence Machine. 2000............................................................ 133

Figura 46: Helio Oiticica e Neville de Almeida. CC1 Trashicapes. 1973 .............................. 137

Figura 47: Helio Oiticica e Neville de Almeida. CC2 Onobject. 1973 .................................. 138

Figura 48: Helio Oiticica e Neville de Almeida. CC3 Maileryn. 1973 .................................... 139 
Figura 49: Helio Oiticica e Neville de Almeida. CC4 Nocagions. 1973 ............................... 140

Figura 50: Helio Oiticica e Neville de Almeida. CC5 Hendrix- War.1973 ............................ 141

Figura 51: Douglas Gordon. 24 Hour Psycho 1993 .......................................................... 143

Figura 52: Viviane Vallades. Autorretrato com duração e sons variáveis I.2011 ................... 151

Figura 53. Viviane Vallades. Autorretrato com duração e sons variáveis I.2011 ................... 151

Figura 54: Viviane Vallades. Autorretrato com duração e sons variáveis II. 2012 ................. 152

Figura 55:Viviane Vallades. Autorretrato com duração e sons variáveis III. 2012 ................ 153

Figura 56: Viviane Vallades. Autorretrato com duração e sons variáveis IV. 2014 ................ 154

Figura 57: Viviane Vallades. Autorretrato com duração e sons variáveis IV. 2014 ................154

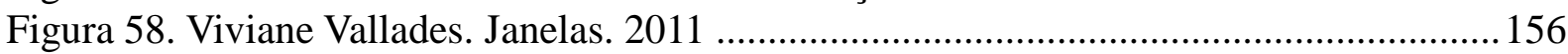

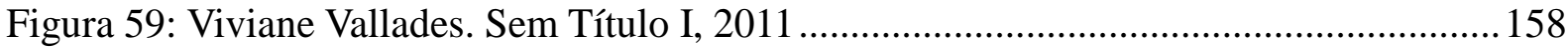

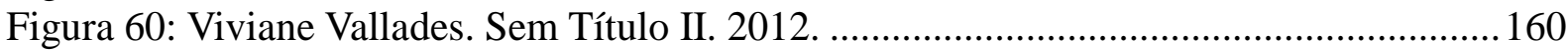

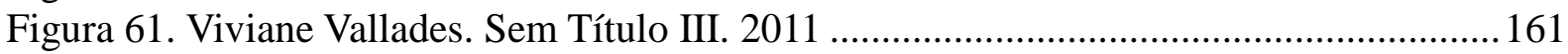

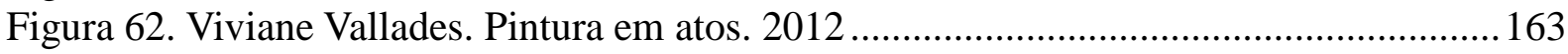

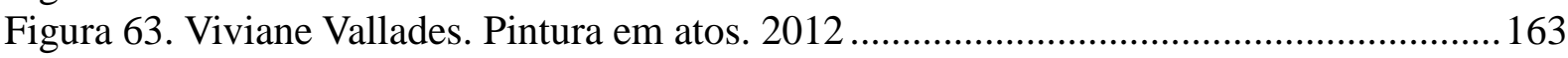

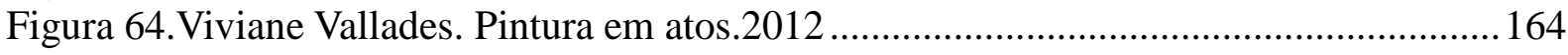

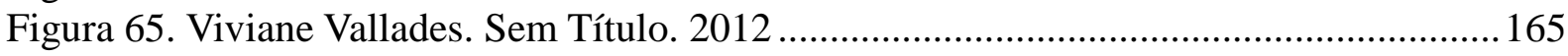

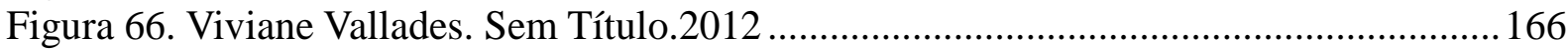




\section{Introdução}

Hoje é muito comum depararmo-nos, nas exposições, galerias de arte, espaço urbano, com a presença de numerosas obras de imagens em movimento projetadas. Estas obras se utilizam em sua construção do dispositivo do cinema: projeção, tela, espaço escuro, filmes, mas produzem alterações na forma padrão dominante de apresentação associada a esse dispositivo: espectador sentado, duração imposta de observação de aproximadamente 1 a 2 horas, sala escura, projeção única e frontal sobre uma única tela, apresentada em uma sala com a arquitetura semelhante à do teatro italiano.

O conceito de dispositivo surge nos anos de 1970, "para definir a disposição particular que caracteriza a condição do espectador de cinema, próximo dos estados do sonho e da alucinação.” (PARENTE, 2009, p. 25). Segundo Parente, este estudo inicia-se com os teóricos estruturalistas franceses Jean-Louis Baudry, Christian Metz e Thierry Kuntzel. Baudry pesquisa a responsabilidade do dispositivo no "efeito cinema", isto é, nos efeitos que o cinema produz no espectador: a impressão de realidade, alucinação. Para o autor, este efeito não estaria tão ligado aos filmes ou à ação discursiva e sim ao "dispositivo do cinema considerado em seu conjunto (câmera, moviola, projetor etc.) e das condições de projeção (sala escura, projeção feita por trás do espectador, imobilidade deste etc.)." (PARENTE, 2009, 25). Outros teóricos, segundo Parente (2009, p.27), apontam a responsabilidade desse "efeito cinema" para a organização discursiva, como pode ser visto no ensaio de Jean-Louis Comolli, Técnica e ideologia: câmera, perspectiva, profundidade de campo (Cahiers du Cinéma, 19712).

"Hoje, está claro que o dispositivo cinematográfico apresenta, ao lado de suas dimensões arquitetônicas e técnicas, uma dimensão discursivo-formal ou estético-formal, que é peça fundamental na constituição de um modelo de representação institucional, cujas bases se encontram no cinema clássico, em particular no hollywoodiano.” (PARENTE, 2009, pp.2728)

Embora esse modelo tenha sido hegemônico, muitas experiências foram realizadas no que se refere ao dispositivo. Seja antes mesmo da formação desse modelo, quando ainda não se sabia como o cinema seria, seja posteriormente a esse modelo, quando foram realizados diversos desvios da estética da transparência (que pretende ocultar o processo de realização do que está sendo visto) e também variações com o número, material e disposição das telas, captação das imagens, suporte de imagens, enfim, modos de apresentação diferenciados do padronizado. 
Nesta pesquisa, interessa-nos estudar a migração do dispositivo do cinema para os espaços de arte e as alterações que estão sendo feitas nesse dispositivo. Nos espaços de arte, as obras são apresentadas em múltiplas projeções, telas em quantidade, de materiais e tamanhos diversos, ocorre a retomada de filmes já conhecidos, com variações em sua duração, em suas imagens, em seus modos de apresentação etc.

A presente dissertação tem as seguintes questões relacionadas com essa migração: 1) Que superfícies de projeção os artistas estão utilizando além da tradicional tela de cinema em sua sala de exibição? 2) O uso de telas de formatos diferenciados do tamanho padrão e o uso de materiais e superfícies como fumaça, árvore, gelo etc., como tela, trazem um retorno da experimentação do pré-cinema e de procedimentos de artes visuais na escolha de materiais e da fisicalidade da obra? 3) Está ocorrendo uma ampliação de modos de exibição das imagens em movimento, semelhante ao momento anterior a hegemonização do modelo de cinema dominante? 4) Quais tipos de poéticas são produzidos por essa forma de apresentação de imagens? 5)De que forma as tecnologias digitais estão modificando a forma de exibição dessas imagens?

Para tentar responder a essas perguntas, levantamos as seguintes hipóteses: que essas alterações de tela, mais frequentes na contemporaneidade, retomam procedimentos de précinema, do cinema antes do modelo hegemônico dominante de sala de exibição, cinemas experimentais e procedimentos de vanguarda das artes visuais. A esta última hipótese acrescentamos analogias nos modos, procedimentos e tratamento das telas, seja na variabilidade de formatos seja na preparação e escolha de materiais diversos que foram sendo utilizados nas artes visuais.

De acordo com essas perguntas e hipóteses, focaremos o estudo nas alterações do dispositivo tela, observando obras que se afastem do modo dominante de apresentação (exibição) de imagens em movimento, principalmente as projetadas: tela única formato grande e retangular, disposição frontal, e assim alteram, a quantidade de telas, sua disposição no espaço, formato e materialidade. Apontamos, como observado pelas hipóteses, que essas formas de apresentação não são inéditas, por isso, trataremos de traçar momentos significativos em que essas alterações foram mais intensas. Faremos esses apontamentos para demonstrar como a tela é um elemento importante e ressaltado em algumas obras e em muitos momentos históricos. Considerando a importância da tela, propomos observá-la em obras que o demonstrem em suas construções. Embora a tela não seja o único elemento das obras e não possa ser vista separadamente, tentaremos destacá-la de um contexto maior para podermos 
estudá-la e dar-lhe um foco mais específico, já que na maioria dos estudos ela é tratada de modo mais superficial. Em nossa pesquisa, encontramos poucos estudos com o foco que damos aqui. Não encontramos muitos autores que tratassem de telas do modo que optamos por fazer (observando seu formato, material, duração, quantidade). Philippe Dubois, que tem como foco o cinema de exposição e o efeito cinema na arte contemporânea, é um dos poucos autores que abordam muitos pontos interessantes sobre a tela. Seus escritos nos guiaram no desenvolvimento desta dissertação, que utilizou tal referência para abordar o tema tela e o cinema de exposição. Dentre os poucos autores que tratam das telas, (embora com focos diferenciados), destacam-se Lev Manovich, Erkki Huhtamo e Charles Musser.

Lev Manovich trata da genealogia das telas em seu livro The Language of New Media no tópico intitulado $A$ Screen's Genealogy no qual se refere principalmente à tela de computador. Neste tópico, ele trata das telas em geral, mas de uma forma mais reduzida justamente em pontos que não nos interessa aqui reduzir. Por exemplo, o autor adota uma posição reducionista (no sentido de que não trata e nem cita as variações de tela) e afirma que as telas não mudaram em seu formato por cerca de cinco séculos, isto é, desde a tela de pintura do século XV, à tela de cinema e à do computador. $\mathrm{O}$ autor também faz uma classificação básica de três tipos de telas: 1) tela clássica, isto é, uma superfície que separa o nosso espaço de outro, cercado por um quadro, enquadramento, e que tem como característica principal a superfície plana, retangular que é destinada à visão frontal e atua como uma janela para outro espaço, este numa escala diferente da do nosso espaço normal e mostra uma imagem permanente (exemplo: pintura emoldurada). (MANOVICH, 2001, p. 95); 2) a tela dinâmica, ainda mantém as características da tela clássica e recebe outra, a de uma imagem em movimento e que mostra o passado. $\mathrm{O}$ autor exemplifica com a tela de cinema, televisão, vídeo.

Tanto a tela clássica quanto a dinâmica utilizam, segundo ele, o mesmo regime de visualidade, isto é, existe uma concentração por parte do espectador, na representação, no que ocorre na tela. A tela desvia a atenção do que ocorre fora dela. Este regime esta, apenas implicitamente na tela clássica e fortemente na tela dinâmica.

Este regime de visualização é possível graças ao fato de que, a imagem singular preenche completamente a tela, seja ela uma pintura, tela ou filme na tela da televisão. É por isso que ficamos tão irritados em uma sala de cinema, quando a imagem projetada não precisamente coincide com os limites da tela: ele perturba a ilusão, tornando-nos conscientes do que existe fora da representação. (MANOVICH, 2001, p.96, tradução nossa)

O autor faz ainda uma ressalva afirmando que existe uma diferença entre o regime de visualidade na tela de cinema e na tela de TV. Nesta última o espectador fica mais consciente 
do espaço externo a tela, devido ao fato desta ter seu tamanho reduzido e também de que os afazeres diários desviam a atenção do espectador da tela. Embora ressalte esta diferença, ele afirma que o regime de visualidade entre uma tela e outra permanece estável: 3) tela real, que dá continuidade às características das telas anteriores com adição de que as imagens podem ser atualizadas em tempo real e assim mostrarem o presente, e exemplifica com o radar, a tela de computador, a TV. Mais uma diferença apontada pelo autor é a de que a tela de computador não mostra uma única imagem mas diversas em janelas simultâneas e assim modifica o regime de visibilidade da tela clássica e da tela dinâmica, isto é concentração em uma única imagem.( MANOVICH,2001,p. 97, tradução nossa)

Erkki Huhtamo, em seu Elements of Screenology:Toward an Archaeology of the Screen, $(2004)^{1}$, se interessa mais em estudar as telas como superfícies de informação (foco diferenciado do nosso), e desenvolve o que ele chama de "Screenology", que segundo ele :

seria um ramo específico dentro do estudo das mídias com foco em telas como
"superfícies de informação". O foco não deve ser apenas em telas como artefatos
projetados, mas também em seus usos, suas relações intermédias com outras formas
culturais e nos discursos que os envolveram em diferentes tempos e lugares.
(HUHTAMO, 2004, p.2, tradução nossa)

Huhtamo (2004, p.4) afirma que a classificação de Manovich (que resumimos acima) é muito esquemática e às vezes confusa. Como exemplo, encontra contradição no fato de que Manovich, em um momento, classifica a tela de TV como tela de tempo real, que mostra o presente (sendo que a TV também pode trazer o passado, além do presente, assim como a tela de computador) e que em outro momento se refere a TV, cinema e vídeo como tela dinâmica. $\mathrm{O}$ autor tem contra-argumentos para a classificação de Manovich sobre a tela clássica, vendo uma falha dele ao dizer que essas telas eram retangulares e planas. Segundo Huhtamo (2004, p. 4) as telas de pintura já foram ovais, miniaturas, enfim tiveram uma diversidade de tamanhos. Para Huhtamo, tratar as telas como não mutáveis em cinco séculos como o faz Manovich é complicado, já que elas foram mudando constantemente. Huhtamo (2004, p.4) se pergunta: O que é típico de uma tela de cinema? A tela de cinema da década de 1930 ou a de hoje mais larga? Sobre essas questões tratadas, concordamos com Huhtamo, que as telas tiveram várias alterações e em nosso trabalho faremos um estudo sobre essa variedade. Trataremos também brevemente das variações das telas do cinema de sala de exibição, já que apontamos que as instalações audiovisuais contemporâneas que trabalham com projeção de

\footnotetext{
${ }^{1}$ HUHTAMO, Erkki. Elements of Screenology: Toward an Archaeology of the Screen. Published in ICONICS: International Studies of the Modern Image, Vol.7 (2004), pp.31-82.Tokyo: The Japan Society of Image Arts and
} 
imagens se afastam do formato de exibição das telas de sala de cinema. Vamos rever as alterações que ocorreram nestas para não cairmos na simples generalização de que foram imutáveis.

Charles Musser também se detém em um estudo que ele chama de "a história da prática de tela". O autor afirma (1994, p.15) que os historiadores encontram problemas quando têm que colocar um ponto de início para certa realização ou novidade e aponta que no caso do cinema muitos historiadores o consideram como uma forma de expressão, totalmente nova. A existência do cinema pressupõe a existência de um pré-cinema. Musser prefere inserir o cinema dentro de um contexto maior, que ele chama de história das práticas de tela. Assim nessa história, o cinema não seria uma ruptura, algo totalmente inédito, mas a continuidade ou transformação da lanterna mágica, na qual um "showman exibia imagens em uma tela, que as acompanha com voz, música e efeitos sonoros.” (MUSSER, 1994, p.15, tradução nossa). Discorrendo sobre essa definição de Musser, Huhtamo (2004, p.8) considera que este deveria incluir também nessa história das práticas de telas duas formas mais antigas que a lanterna mágica: o teatro de sombras que, segundo Huhtamo, seria a mais antiga e conhecida dessas práticas e também acrescentaria os panoramas ao estudo, principalmente os panoramas em movimento. Embora não fossem primariamente de fato, uma forma à base de projeção, os panoramas trabalhavam também os elementos de luz como os efeitos especiais. Para o autor, os panoramas em movimento, resguardadas as diferenças estéticas e técnicas com a lanterna mágica têm em comum com ela propor uma viagem para outros espaços, ter em suas apresentações um conferencista, ter som etc. Desse modo, ele as englobaria, portanto, como práticas de tela.

Em nosso estudo trataremos brevemente das sombras chinesas por usarem a tela semitransparente e a performance diante dessas e também dos panoramas e algumas derivações destes, pois consideramos que nessas práticas a tela também foi pensada e ressaltada como um elemento plástico, visual. Reforçamos ainda que o panorama é uma pintura e seu formato, disposição espacial será utilizado também para apresentações da imagem em movimento no momento anterior da hegemonização do modelo de cinema de sala de exibição. Desta forma também aqui apontamos uma troca de procedimentos e usos dos formatos das telas de pintura das artes visuais com o formato das telas para exibição de imagens em movimento. Também escolhemos tratar dos panoramas por sua busca em produzir uma imersão e por observarmos que este modo de exibição circular, panorâmico é muito retomado atualmente. 
A leitura desses teóricos citados não nos permitiu achar o foco que pretendíamos, pois nenhum dos três autores detinha-se na materialidade, na quantidade, nos formatos das telas e a relação com as artes visuais neste sentido. Desta forma, voltamo-nos para leituras focadas em dois aspectos fundamentais: a) sobre a arqueologia do cinema, do pré-cinema, cinema dos primeiros tempos, cinema de vanguarda, experimental, expandido e de exposição, para observar descrições, usos e obras que trabalhavam em telas diferenciadas; e b) também para a história da arte para entender como a tela que Manovich chama de tela clássica foi sendo alterada e trabalhada e como os materiais usados no campo das artes visuais foram sendo ampliados. A propósito, detectamos semelhanças entre eles e o uso de telas de fisicalidade e materialidade diferenciados em instalações contemporâneas que se afastam da apresentação padrão comum a trabalhos audiovisuais (como monitores ou tela de cinema de sala de exibição). Por meio dessas leituras, focamos em descrições e tratamentos dados às telas em geral, principalmente os desvios com a padronização desse elemento.

Para buscar a confirmação ou não das nossas hipóteses dividimos esta dissertação em três capítulos. O primeiro capítulo traz momentos na história da arte em que são enfatizados o uso e preparação de telas, variação de formatos, modos de preparo para receber tinta e ampliação e diversidade de materiais usados nas obras ou como obras. Focando no que se refere a esta expansão de suportes e materiais no uso intenso do corpo do artista. O corpo principalmente do artista também foi tratado no capítulo 2 no qual consideramos a relação desses corpos com as imagens em movimento e os modos de exibição desses trabalhos. Ainda no capítulo 2 usamos a história do cinema para extrair momentos significativos de alterações na tela iniciando com o pré-cinema, com ênfase nos estudos de Mannoni sobre a arqueologia do cinema. Este autor nos traz descrições de como as telas foram vistas e usadas no précinema. Iniciamos o estudo brevemente com as sombras chinesas e passamos à câmera escura, lanternas mágicas e fantasmagorias. Neste capítulo ainda comentamos sobre o primeiro cinema, a formação do modelo dominante de apresentação das imagens e algumas alterações que esse modelo produziu, para passarmos aos cinemas de vanguarda e cinema expandido, sempre com foco nas alterações da tela. No capítulo 3 abordarmos o cinema de exposição, suas principais características, detendo-se também no estudo das telas. Neste capítulo utilizaremos fortemente como referencial teórico o autor Philippe Dubois que divide em grupos e figuras as obras dos artistas que trabalham utilizando e alterando o dispositivo do cinema nos espaços de arte. Desenvolvemos uma classificação nossa para as telas a partir de alguns exemplos e de uma das figuras desenvolvidas pelo autor, a figura de tela, Nosso 
objetivo foi o de classificar as telas pelas suas propriedades mais ressaltadas, observando o que essas propriedades diferenciadas da tela padrão podem possibilitar durante a exibição das imagens e como podem ampliar o modelo hegemônico e padronizado de apresentação das imagens em movimento. Ainda no capítulo III colocamos em destaque as análises de algumas obras, que entendemos trazer em suas concepções conceitos que nos ajudam na reflexão de nossas hipóteses: Experiência de Cinema (2004), de Rosangela Rennó, 24 Hour Psycho (1993), de Douglas Gordon, The Influence Machine (2000), de Tony Oursler, Cosmococas (1973), de Hélio Oiticica e Neville D’ Almeida (as que foram realizadas nessa parceria), e a descrição de obras de nossa autoria produzidas antes e durante o mestrado e que foram a motivação para a pesquisa. Foi a partir da produção de obras de nossa autoria que utilizavam telas diferenciadas para exibição de imagens em movimento que surgiu a vontade de entender melhor sobre o assunto. A escolha das obras que serão analisadas se deu pelo uso de telas diferenciadas da tela padrão de sala de cinema de exibição, seja no material, na disposição espacial ou na quantidade.

$\mathrm{Na}$ conclusão, entendemos que nossas hipóteses são confirmadas em sua totalidade e que as questões colocadas por nós no início de nossa pesquisa levaram nossos estudos à afirmação de que as telas são elementos importantes e ressaltados em muitos trabalhos de hibridização entre artes visuais e cinema, como observado nas obras escolhidas e analisadas. Também inferimos que, em geral, no audiovisual mais tradicional, as formas de exibição ficam mais ligadas à projeção em tela padrão e a monitores de TV, já em algumas obras instalativas que utilizam imagens em movimento, exibidas em museus, galerias, ocorre uma hibridização com as artes visuais tanto por compartilharem dos mesmos espaços de exibição como também pela analogia de procedimentos ao trabalharem com diversas superfícies e diversos materiais visuais como fumaça, árvores, gelo etc. Desta forma, tais obras se aproximam assim do campo das artes visuais, em que materiais, sempre foram pesquisados e usados tanto pela sua materialidade em si como pela sua carga de significados.

Concluímos também que está ocorrendo um retorno aos procedimentos do pré-cinema, como o uso de fantasmagorias, em que imagens aparecem e desaparecem repentinamente sobre fumaças, telas transparentes etc., e que as experimentações com o aparato do cinema parecem retornar e também dar continuidade às pesquisas e experimentações dos cinemas que se afastam do modelo hegemônico de sala de exibição.

As mudanças realizadas por esses outros cinemas diferentes do modelo hegemônico de sala de exibição incorrem, principalmente na contemporaneidade, em algumas questões sobre 
a própria definição de cinema. Tais questões ficam mais complexas quando se observa a presença de diversas imagens projetadas em espaços de arte, espaço urbano, as diferentes posturas dos espectadores diante das imagens em movimento nesses espaços, a apresentação diferenciada das imagens em relação ao modelo padrão do cinema convencional, e também as mudanças de suportes do cinema, isto é, de fotoquímico para eletrônico e digital, ou todos estes suportes mesclados, que geram inevitavelmente as perguntas: Isto é cinema? O que é o cinema? Isto ainda é cinema?

Tais mudanças e questões são vistas e rotuladas na contemporaneidade por muitos teóricos, como Raymond Bellour e Pascale Cassagnau, em conceitos como "outro cinema", "terceiro cinema", "pós-cinema", "cinema de exposição" e, por Dubois, que trabalha tanto o termo cinema de exposição como usa a expressão "efeito cinema", que seria o uso de formas artísticas que se inspiram no modelo cinema e de sua linguagem (sala escura, projeção, espectadores sentados, imagens em sequência, campo, contracampo etc.) mas cometam desvios com esse modelo

Diante de todos esses questionamentos, optamos por usar a palavra cinema, neste estudo, de modo mais abrangente, isto é, como a etimologia da palavra assim a define: do grego kínema-ématos+gráphein, "escrita do movimento". Fizemos esta opção porque em nossos estudos trataremos de vários tipos de escrita do movimento e de diversificados modos de exibição das imagens em movimento. A palavra cinema fica sempre associada, como já dito, a uma sala escura, com arquitetura semelhante à do teatro italiano, a projeção de imagens em movimento e um filme que conta uma história geralmente entre 1 e 2 horas. Esta forma hegemônica chamada de forma cinema por André Parente (2009, p. 24) é só a uma forma particular de cinema. Na verdade, existiram outras formas de cinema que nem sempre contavam histórias, nem sempre foram exibidos nessas salas específicas e de forma padronizada. Julgamos importante colocar aqui na introdução como entendemos o conceito de cinema e em que sentido esta palavra será usada.

Feitas as devidas ressalvas, concluímos também que o cinema está sendo estendido para fora das salas tradicionais de exibição e entrando mais fortemente em outros espaços para além delas, isto é, em museus, em galerias e no espaço urbano, que possibilitam um novo arranjo instalativo ou uma retomada, uma continuação das experimentações realizadas com seu dispositivo para além do modelo hegemônico de cinema de sala de exibição.

\footnotetext{
${ }^{2}$ Machado Arlindo. Pré-cinema e pós cinema. Campinas, SP: Papirus, 1997. p. 211.
} 


\section{Capítulo 1: Tratamentos em telas e expansão de materiais e tecnologias usados no campo das artes visuais}

De geração a geração o homem tenta exteriorizar um pensamento, uma ideia, uma vontade e, para isso ele necessita materializar esses conceitos de forma física para que outros ao seu redor possam entender, compartilhar, se emocionar etc. A "necessidade que temos de criar imagens, fez com que procurássemos várias superfícies e materiais que servissem de suporte para esses registros.” (SOGABE, 1990, p.9)

Segundo o autor, os dados materiais e técnicos estão presentes em todas as imagens artísticas e “os termos Artes Plásticas, Arte Multimídia, 'Computer Art', etc, são denominações que carregam sempre um aspecto caracterizado pelo material ou processo." (SOGABE, 1990, p.1)

Para ele, os termos materialidade e imaterialidade não são opostos. O primeiro termo se refere a uma materialidade mais palpável como a pintura, por exemplo, e no segundo é apenas mais fluída como as imagens técnicas ou eletroeletrônicas. $\mathrm{O}$ que as difere, segundo o autor, é apenas que a energia é organizada de forma mais estável em uma e menos estável em outra, definindo assim algumas características diferenciadas. Ainda segundo o autor (1990, p. 3) um material como uma madeira, por exemplo, pode ser usado apenas como suporte para uma pintura, pela sobreposição de tinta sobre esta superfície mas também se podem explorar as características deste material em si apresentando assim sua própria expressividade, explorando sua materialidade.

O conceito de materialidade não se opõe ao conceito de matéria, vai além. A matéria
é a preocupação mecânica com o suporte material, ao passo que a materialidade
abrange o potencial expressivo e a carga informacional destes suportes, englobando
também a extra-materialidade dos meios de informação. Operar sobre a matéria e
sobre a materialidade determina maneiras diferentes de comportamento. Operar
sobre a matéria significa a presença de um autor-dominador, que impõe ao suporte
material as suas marcas individuais. (LAURENTIZ ${ }^{3}$ 1988, p. 104 apud SOGABE
1990, p.3)

A partir destes conceitos vamos traçar um breve panorama das telas na pintura, como foram tratadas e a posterior ampliação dessa materialidade palpável e mais fluida no campo das artes visuais. De acordo com nossa premissa, algumas obras trabalham com a mistura dos dois, isto é, obras que trabalham com o fluido característico de projeção de imagens, sejam elas de filmes, vídeo etc., mas que façam uso e ressaltem a materialidade mais palpável e mais

\footnotetext{
${ }^{3}$ LAURENTIZ, Paulo. A holarquia do Pensamento Artístico. Tese de Doutorado, PUC-SP, 1988.
} 
comum nas artes visuais durante sua exibição, por fazer uso de escultura e materiais físicos, como tela. Modifica-se assim o papel de neutralidade das telas de cinema ou monitores tradicionais. Algumas dessas obras serão vistas nesta dissertação no capítulo 3, mais especificamente no tópico 3.4.2 e 3.4.5 .

Na pintura, segundo Villarquide Jevenois (2004, p. 99), suporte é a base sobre a qual ela é realizada. E pode ser feita em vários suportes: parede, tecidos, papel, pergaminho, metal etc.

Segundo a autora o uso da tela como suporte, que acabou substituindo gradualmente a madeira, começou no século XV e principalmente no século XVI, mas seu uso encontra-se em outros períodos bem anteriores como no século I-III d.C em retratos de Múmias de El Fayum. O seu uso pode ser observado em passagens dos textos de Plínio em seu tratado de pintura:

Não vou deixar de mencionar a loucura que reina em nossa época no campo pictórico. O imperador Nero ordenou pintar seu retrato em uma tela de 120 metros, medidas colossais, insólitas até o momento [...] Plinio: OP. Cit. Livro 35 "Los pintores" apud JEVENOIS, 2004, p. 100, tradução nossa) ${ }^{4}$

Segundo Sogabe (1990, p. 11), o suporte mais usado para a pintura era a princípio a madeira por ser mais compatível com a têmpera. Posteriormente, com o surgimento da pintura a óleo, utilizava-se mais o linho como suporte; ainda segundo o autor, durante o século XX o tecido era o suporte mais usado, mas o linho foi substituído pelo algodão cru devido ao preço e escassez do primeiro.

Fernando Montesinos relata que a tela foi convertida no suporte predileto durante séculos na pintura ocidental, dentre outros motivos, por poder ter tamanhos maiores e ainda assim serem transportáveis. A generalização do uso da tela foi paralela à utilização da pintura a óleo "ambas novidades, de suporte e de técnica, produziram uma autêntica revolução."(MONTESIVOS, 2010, p.49)

As imagens realizadas sobre madeira, tela etc., possuem qualidades físicas que as tornam perceptíveis. Aumont (1993, p.139). Sendo um objeto físico, dever ter tamanho, e ser construído e para isso necessita-se de técnicas e conhecimentos de conservação, ela deve ser apresentada em um espaço e este pressupõe maneira de construir percepções de valor dessas imagens, isto é, esse valor é social.

As imagens nas igrejas, nas cavernas, por exemplo, tinham valor de culto nos espaços

\footnotetext{
${ }^{4}$ No voy a dejar de mencionar la locura que reina en nuestra época en el terreno pictórico. El emperador Nerón ordenó pintar un retrato suyo de medidas colosales,en un lienzo de 120 piés, insólito hasta esse momento [...]
} 
de arte, valor de exposição. O que está num museu é considerado arte. O conjunto: imagem, tamanho dela, como foi feita, em que local se encontra, são dispositivos. Segundo Aumont, “o dispositivo é o que regula a relação entre o espectador e suas imagens em determinado contexto simbólico”. (AUMONT, 1993, p.192, grifo do autor)

Resumindo, o tamanho da imagem, o local onde está inserida, a técnica da qual foi feita etc., são fatores que compõem dispositivos de imagens. Trataremos agora de algumas características físicas das obras.

\subsection{Suportes:}

As imagens encontradas nas paredes, nas cavernas, nas igrejas eram realizadas sobre suportes fixos, isto é, presos ao solo. "O acesso à esse tipo de imagem dá-se forçosamente pelo deslocamento das pessoas para o sítio, transformando-o num espaço público.”(SOGABE, 2002, p 126)

Foi durante o Renascimento que as obras foram destacadas das paredes, e os quadros tornaram-se menores, transportáveis. "A relação do espectador com o quadro é não só mais íntima como se torna também mais puramente visual [...]” (AUMONT, 1993, p. 140)

Esse tipo de produção de imagem é classificado por Santaella e Nöth (2008c) como paradigma pré-fotográfico, isto é, quando as imagens são realizadas a partir do modo de construção artesanal e sua característica básica "está na realidade matérica das imagens, quer dizer, na proeminência com que a fisicalidade dos suportes, substâncias e instrumentos utilizados impõe sua presença." (SANTAELLA ; NÖTH, 2008c, p.163). Segundo os autores, neste paradigma as obras são únicas e a imagem e seu suporte são inseparáveis. Para criar tais imagens o produtor deve ter habilidade e imaginação, pois são realizadas para figurar o visível e o invisível, funcionam como metáfora, janela para o mundo e, como imagens únicas, devem ser conservadas num museu. $\mathrm{O}$ acesso a elas se dá por transporte do receptor, uma vez que são feitas para contemplação.

O suporte foi usado de duas formas principais na história da arte: transparentes ou opacas. A transparência seria a tentativa de eliminação visível do suporte, sobressaindo o que nele havia sido trabalhado. No opaco, a própria materialidade do suporte se destaca, sendo importante para a obra. Nas obras que trabalhavam com o conceito de transparência o suporte ficava em segundo plano ele era trabalhado para que não fosse visível. O tratamento no suporte nessas obras transparentes visava à iluminação (reflexibilidade) das cores aplicadas em camadas.

Observamos o procedimento de ocultamento do suporte, dentre outros artistas, nas 
obras de Jan Van Eyck (1422-1441) em sua obra O Matrimônio Arnolfini (1434) produzido em óleo sobre madeira.

\begin{abstract}
Os primeiros pintores holandeses manifestavam uma considerável uniformidade técnica. Todos pintavam em tábuas de carvalho, com base de gesso branco: o desenho era feito em uma camada preparatória que logo se impermeabilizava recobrindo-se de óleo. Assim como os pintores italianos, mesclavam a base com cola animal, que ocultava por completo o grão da madeira, e logo a poliam até que parecesse bem lisa. (JANUSZCZAK, 1981, p.18, tradução da autora)
\end{abstract}

Já em Ticiano (1487-1576) observa-se, segundo Januszczak (1981, p.34), que o artista trabalha com vários tipos de telas, cuja espessura foi sendo alterada no decorrer de sua carreira: de tramas finas a mais grossas, dando assim ênfase na materialidade do suporte.

Observa-se também o uso transparente ou opaco nas pinceladas dos pintores. Os dois exemplos de artistas sobre suportes, logo acima, serão também aqui exemplos de alterações nas pinceladas. Em Jan Van Eyck temos uma pincelada uniforme, lisa, quase impossível de se ver; já nas obras de Ticiano existe uma materialidade visível sobre a superfície e um tratamento da pincelada, "a superfície final não é lisa nem uniforme; o efeito de textura é surpreendente".(JANUSZCZAK, 1981, p.37, tradução da autora).

Como Ticiano, muitos outros artistas trabalhavam com pinceladas visíveis, soltas e inacabadas. Nesta mesma linha temos as obras de Rembrandt van Rijn (1606 -1669), William Turner (1775-1851), dentre outros.

Edgar Degas (1834 - 1917) trabalhava com o suporte tela e também com o suporte de papel e neste último usava a técnica do pastel, preservando a textura e a cor do papel em sua obra final.

Os artistas em sua maioria deixavam entrever a textura do suporte, mas ainda em primeiro plano ficava o trabalho realizado com pincéis, espátulas e tinta.

\title{
1.2 Formato
}

Em pintura, embora ocorra de fato a predominância de formato retangular, muitos outros formatos foram utilizados. Para Sogabe:

\footnotetext{
A importância do formato de um suporte não parece ter convencido a maioria dos artistas, mas encontramos na história da pintura vários trabalhos que colocam o formato ao mesmo nível de importância da cor e de outros elementos da pintura. SOGABE (1990, p. 12)
}

Segundo o autor (1990, p.14), o formato retangular é o mais usado por não interferir tanto na imagem pintada. Mas, em algumas obras, segundo Januszczak (1981, p.136), o 
formato tem relação com a imagem pintada como a série de Picasso de naturezas mortas em formato ovaladas, que remetem a uma mesa vista em perspectiva e com forma arredondada. (SOGABE, 1990, p.14)

As alterações de formato padrão usado na pintura, são vistas também, de acordo com Sogabe nas obras de Frank Stella. Nos anos 60 segundo Vogt (1981), esse artista realizou “dentro da pintura Hard Edge suas 'Shaped Canvases' onde a forma da tela é determinada pela própria forma da imagem e vice-versa, tentando integrar ambas numa só." (SOGABE, 1990, p. 15)

Segundo Michael Archer, Frank Stella fez algumas séries explorando formatos diferentes do padrão para a tela, e nessas utilizava em algumas das obras tinta de cor alumínio e em outras cobre. O artista utilizava "telas formatadas, cortando chanfraduras no retângulo padrão para as pinturas em alumínio" e ia construindo "superfícies numa variedade de formatos retilíneos para as pinturas em cobre.” (ARCHER, 2001, pp.46-47)

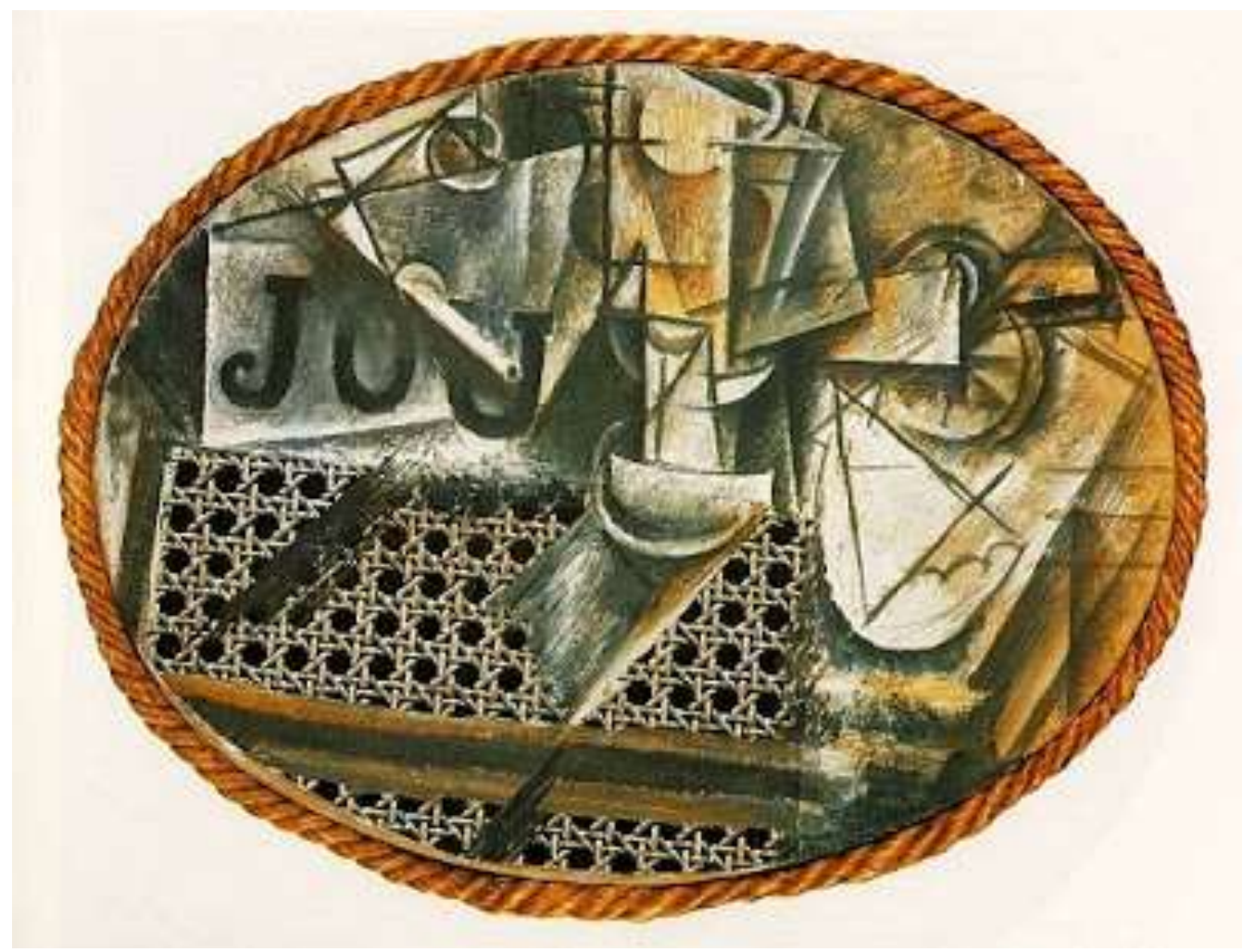

Figura 1: Pablo Picasso. Natureza Morta com Cadeira de Palha, 1912 


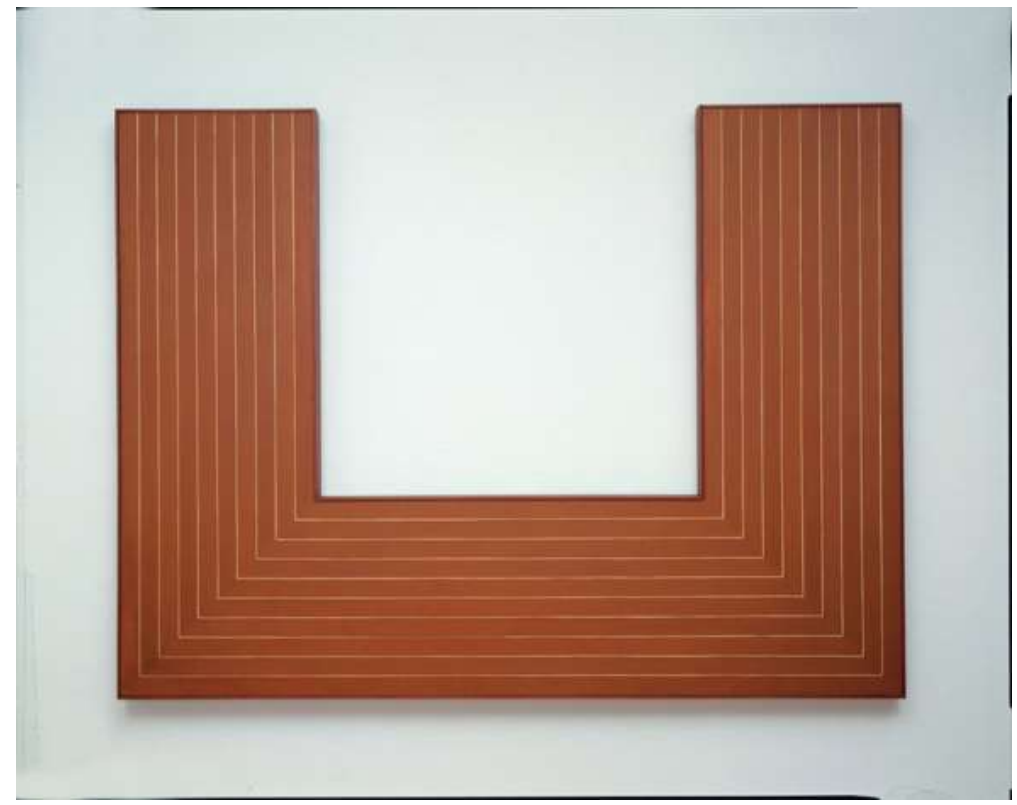

Figura 2: Frank Stella. Lake City, 1960-1961

Fonte: http://artnews.org/kunstmuseumwolfsburg/?exi=35182

\subsection{Crise da representação}

A partir dos impressionistas a pincelada começa a ser mais rápida, fluida, para captar as modificações atmosféricas e produzir obras ao ar livre. A partir da arte moderna podemos observar mudanças nos usos dos materiais e modos de trabalhar em telas ou outros suportes. Estas mudanças ocorrem por várias razões, dentre as quais estaria a crise da representação. Esta crise também está ligada ao aparecimento da fotografia, que certamente a motivou, assim como as novas possibilidades para a pintura. "[...] a fotografia trouxe novos estímulos para a pintura de maneiras variadas, pois a fotografia transformou, antes de tudo, os nossos modos de ver." (SANTAELLA 2008b. p. 22)

Segundo a autora, desde 1839, a fotografia e a pintura dialogam. Muitos artistas foram influenciados pela fotografia, (como os artistas futuristas, que tiveram a influência de EtieneeJules Marey, por exemplo) ou foram influenciados pelos procedimentos de fotógrafos: “ [...] logo após a invenção da fotografia, os pintores deixaram seus ateliês para flagrar a vida cotidiana do mesmo modo que os fotógrafos." (SANTAELLA, 2008b, p.22)

Faremos agora um breve panorama da crise da representação, focando o ponto em que não havia mais necessidade de imitação; os próprios materiais, suportes, ou seja, a própria 
pintura, seus elementos, procedimentos era o que de fato importava. Posteriormente nos fixaremos em como os novos meios tecnológicos, principalmente os associados à imagem em movimento, se hibridizaram nas artes visuais. Focaremos as imagens em movimento que modificaram a forma de relacionamento com imagens nos museus e em como o próprio dispositivo do cinema foi retomado e alterado nesses espaços.

\subsection{Panorama da crise da representação}

“Transformações sociais, políticas e econômicas ocorriam paralelamente ao desenvolvimento filosófico e científico, bem como o colapso de sistemas e valores de autoconfiança e sobrevivência a longo prazo.” (STANGOS, 1991, p. 7). De fato, no século $\mathrm{XX}$, muitas foram as modificações em diferentes campos, inclusive no das artes.

Segundo Priscila Arantes, algumas dessas modificações foram: "a crise dos suportes tradicionais, a crise do conceito de mimese, a mudança de paradigma da obra de arte fechada para obra de arte-processo, o rompimento com a dicotomia obra/público, o aspecto processual e temporal das práticas artísticas contemporâneas [...]”. (ARANTES, 2005, pp. 21-22)

Para a autora, a crise da representação foi um fator que contribuiu para o afastamento em relação à tradição do passado, isto é, contribuiu para o afastamento do "ideal de representação da natureza (mimese) herdado da tradição. (ARANTES, 2005, p.32). Os impressionistas ao trocarem seus ateliês pelo ar livre, e "retratar" os objetos com a luminosidade natural. romperam com "a pintura naturalista, baseada na imitação da natureza e no espaço racional renascentista [..] (ARANTES, 2005, p. 33). Ainda segundo a autora, a incorporação da cor na apreensão do objeto em sua luminosidade natural abre caminho para utilização da cor arbitrária pelos fauvistas.

Muitos artistas modernos, inclusive Picasso, tiveram contato com as pinturas de Cézanne (que reduziu os objetos à formas básicas mais simples como cones, cilindros e esferas) e com as obras africanas, (estas priorizam as ideias sobre seu tema, em oposição ao naturalismo). Segundo Stangos (1991, p.40), Picasso percebeu que a arte africana (por priorizar as ideias sobre seu tema ao invés do naturalismo) ia ao encontro do que queriam os novos pintores, isto é, ao mesmo tempo uma arte representacional e antinaturalista. Durante 500 anos desde a Renascença italiana, os artistas tinham sido guiados pelos princípios da perspectiva matemática e científica, de acordo com os quais o artista via o seu modelo ou objeto de um único ponto de vista estacionário. Com as obras cubistas de Picasso é como se este tivesse andado 180 graus em redor do seu modelo e tivesse sintetizado duas sucessivas 
impressões numa única imagem. O rompimento com a perspectiva tradicional resultaria, nos anos seguintes, no que os críticos chamaram de visão "simultânea", a fusão de várias vistas de uma figura ou objeto numa única imagem.

Além dessas contribuições para a ruptura da forma de representação que vinha fixa desde o Renascimento, os cubistas, por volta de 1911/1912, começam a desenhar letras nos quadros cubistas e a acrescentar materiais do mundo concreto, como jornais, papéis pintados, areia, estopa, prego etc. Ao invés de representação, apresentam o real.

A partir dos papéis colados inseridos por Braque e Picasso:

[...] uma outra porta se abre: já não há nada que impeça o uso deste material e não daquele. Porque não a areia, a estopa, o pedaço de forro de parede, de espelho? Porque apenas a tela e não qualquer pano - a estopa, o pano de cozinha? Ninguém mais que Picasso deu impulso a essa vontade "dadaísta" de romper definitivamente com a "pintura". (GULLAR, 1998, p.23)

Podemos observar aqui o caminho aberto às experimentações e usos de materiais e suportes não convencionais no campo da arte.

Seguindo esta ampliação de materiais, temos o dadaísmo, que levou a crise dos suportes tradicionais de arte até seu ponto mais radical, quando Duchamp insere objetos prontos no contexto da arte como: rodas de bicicleta, vaso sanitário, porta-garrafas etc. Desta forma, além da crise da representação, Duchamp trouxe questões relativas às obras retinianas, ao papel do artista, e deu ênfase para as ideias na arte. Duchamp continua também o que os cubistas já tinham feito: adicionar objetos retirados do real, não realizados pelo artista. Tanto Duchamp quanto os surrealistas em seus jogos coletivos (cadavre exquis), trouxeram:

[...] uma ruptura com os padrões tradicionais da obra de arte, um questionamento do papel do artista e da visão do artista-gênio no cenário mais geral da arte.

A crise da representação e o questionamento do papel do artista colocados em debate no início do século XX trouxeram também um rompimento com os suportes tradicionais de representação, como a pintura e a escultura. (ARANTES, 2005, pp.34-35)

Outro movimento da arte moderna, que dá ênfase aos materiais, aos suportes e avança na libertação do objeto de molduras ou apoios tradicionais foi o Construtivismo, um movimento surgido na Rússia entre 1910 e 1920. O Construtivismo considera tanto a pintura como a escultura, como construções e não como representações ${ }^{5}$. As ideias construtivistas surgiram "inicialmente, das criações tridimensionais de Tatlin, apresentadas na exposição “0:10", de dezembro de 1915, em Petrogrado, junto com as primeiras telas suprematistas de

\footnotetext{
${ }^{5}$ Informação retirada de http://www.itaucultural.org.br/aplicExternas/enciclopedia_ic/index.cfm?fuseaction=termos_texto\&cd_verbet $\underline{\mathrm{e}=3780}$.Acesso em $10 \mathrm{dez}$. de 2013
} 
Malevich.”. (DABROWSKI, 1986, p.70)

As pinturas em relevo de Tatlin de 1913-1914 e seus contrarrelevos de 1914-1915, e as obras construtivistas em geral tiveram influências do futurismo e de obras cubistas como Guitarra de 1912 de Picasso, no que se refere "a obra aberta, construção-escultura [...] Essa transformação tri-dimensional da estrutura planar dos quadros do Cubismo Analítico Pleno foi crucial para o aparecimento do Construtivismo" (DABROWSKI, 1986, p. 22). Tatlin se interessou pelos usos que os cubistas fizeram de materiais do cotidiano nas obras e das construções abertas de Picasso, mas, segundo Dabrowski (1986, p.70) existiam diferenças das obras de Tatlin e das construções de Picasso. Isso era mais notória no enfoque dado por Tatlin aos materiais.

Essa diferença é bem observada por uma fala de Picasso6: "A folha de jornal nunca foi usada a fim de se fazer um jornal. Foi usada para se tornar uma garrafa ou qualquer coisa desse tipo. Nunca foi usada literalmente, mas sempre como um elemento deslocado de seu significado habitual para outro significado.” (PERLOFF, 1993, p. 133)

Se para Picasso o material não é o mais importante, como observado acima, para Tatlin o material dita a forma. "Os materiais e suas relações nos relevos de Tatlin eram apresentados como o que eram, não como um meio de representação de algo mais." (GOODING, 2002, p. 48). Para Tatlin, segundo Perloff (1993, p.136), as possibilidades formais do metal, por exemplo, são diferentes da madeira. O metal reflete a luz; a madeira tem sua cor natural. $\mathrm{O}$ metal tem maleabilidade diferente da madeira, que é mais rígida e assim pode adquirir diferentes formas. Cada material tem suas características e ele as explora. $\mathrm{O}$ artista utiliza-se também do vidro por sua transparência, que possibilita a transição entre espaço do contemplador e da obra de arte.

Desta forma, os conceitos desenvolvidos e trabalhados nos relevos de Vladimir Evgrafovic Tatlin (1885 - 1953), "alteraram radicalmente os conceitos de material, feitura, construção e as categorias tradicionais de pintura, escultura e arquitetura." (DABROWSKI, 1986, p.22)

Para Tatlin "esses contra-relevos ficavam numa zona intermediária entre pintura e a escultura [...]" (GULLAR, 1998, p 139)

Segundo Gooding, "Tatlin efetuou um salto quântico qualitativo: do quadro para o objeto icônico, no qual os materiais são tão significantes quanto a imagem.” (GOODING, 2002, p.45)

\footnotetext{
${ }^{6}$ Ver Gilot ; Lake. Life with Picasso, p. 70
} 
As obras de Tatlin embora tenham sido inspiradas pelo cubismo e futurismo, possuem diferenças importantes e que devem ser observadas. Os seus contrarrelevos ou também chamados 'relevos de canto de parede', devem ser pendurados, sem suporte em sua base "que limite ou defina a sua extensão física no espaço. A referência implícita à pintura, a algo emoldurado, noutras palavras, não está mais presente.” (PERLOFF, 1993, p. 137)

Isto diferencia essas obras das dos futuristas. A obra Garrafa de Boccione, por exemplo, usa ainda um suporte para a escultura enquanto nos contrarrelevos de Tatlin, como nota Rosalind Krauss em Passages in Sculpture, este "relaciona os seus relevos de canto de parede aos planos de paredes reais, que servem de suporte físico da obra [...]" (PERLOFF, 1993, p.137)

As obras de Tatlin tornavam-se assim parte do ambiente; não estavam separados por uma moldura ou por um pedestal. Os contrarrelevos de Tatlin têm como objetivo uma construção, uma "assemblage construída de fragmentos justapostos - arame, ferro, alumínio, madeira - materiais cuja natureza é deixada intacta ainda que sua coordenação lhe dê uma nova vida." (PERLOFF, 1993, p. 138)

Os contrarrelevos de Tatlin foram enfatizados em nosso texto pois em suas obras o artista ênfase ao material e à forma de ocupar o espaço, libertando o objeto de molduras, pedestais, o que causaria dificuldade para categorizar a especificidade da obra. Segundo Gullar (1998 pp. 146-147), Tatlin:

rompe com o espaço virtual da tela para criar um objeto virtual: um contra-relevo.
Liberto da massa e da base - preso por fios de arame no encontro de duas paredes -
o contra-relevo é um objeto novo na arte. Não é relevo, pois não possui uma
superfície primeira determinada sobre a qual as formas se desenhassem em relevo;
não é escultura pois não partiu de massa dada a ser esculpida e não possui haste; não
é pintura, pois foge da superfície bidimensional e da representação dentro dessa
superfície. Tatlin mesmo o definiu como "uma continuação da pintura."

O movimento russo desde o suprematismo de Kazimir Malevich, o Construtivismo, o não-objetivismo o Manifesto do realismo dos irmãos Pevsner e Gabo e principalmente o construtivismo e nele os contra-relevos de Tatlin são importantes, pois trazem " a passagem da pintura para o espaço”. (GULLAR, 1998, p 147) 


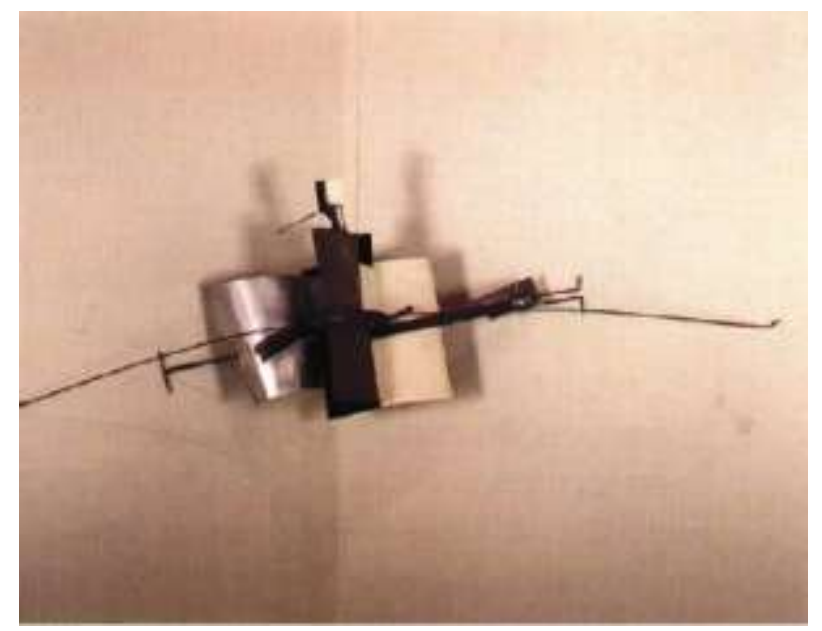

Figura 3: Vladmir Tatli, Contra-relevo de canto, 1915

Fonte: http://construtivismo-up.blogspot.com.br/2011/06/analise-das-obras.html

Depois da Segunda Guerra Mundial, segundo Dabrowski (1986 p. 166), muitos artistas europeus migraram para os Estados Unidos e o centro de interesse da arte mudou-se para Nova York. Deste deslocamento passaremos agora rapidamente pelo expressionismo abstrato para trazer a ligação deste com o corpo, no sentido de que este movimento (dentre outros motivos, sociais, econômicos etc.) abre caminho para o uso do corpo do artista como suporte e que "a ação artística passa a ter precedência sobre o tema da pintura" (RUSH, 2006, p.30).

Em 1949 Pollock trabalha com seu corpo jogando tinta sobre a tela. Nessa época estava ocorrendo também em outros locais a mesma prioridade relatada acima da ação artística sobre o tema, como visto nos cortes espaciais de Lucio Fontana, e a realização de cortes do japonês Shozo Shimamoto em Holes. O contato com a obra de Pollock, principalmente através da documentação fotográfica e do filme realizado por Hans Namuth, foi importante para muitos artistas (Allan Kaprow, Yves Klein, Piero Manzoni etc.) que logo ampliaram:

[...] a arte gestual de Pollock para Eventos, Happenings e Performances reais. As revoluções social e sexual dos anos 60 encontraram expressão na arte que se afastava da tela em busca de ações que incorporavam o observador à obra de arte. Para artistas americanos em meados do século era apenas uma questão de dar um pequeno passo entre a pintura de ação (a aplicação livre e generalizada de tinta de Jackson Pollock) e a própria ação como forma de arte. (RUSH, 2006, p.30) 


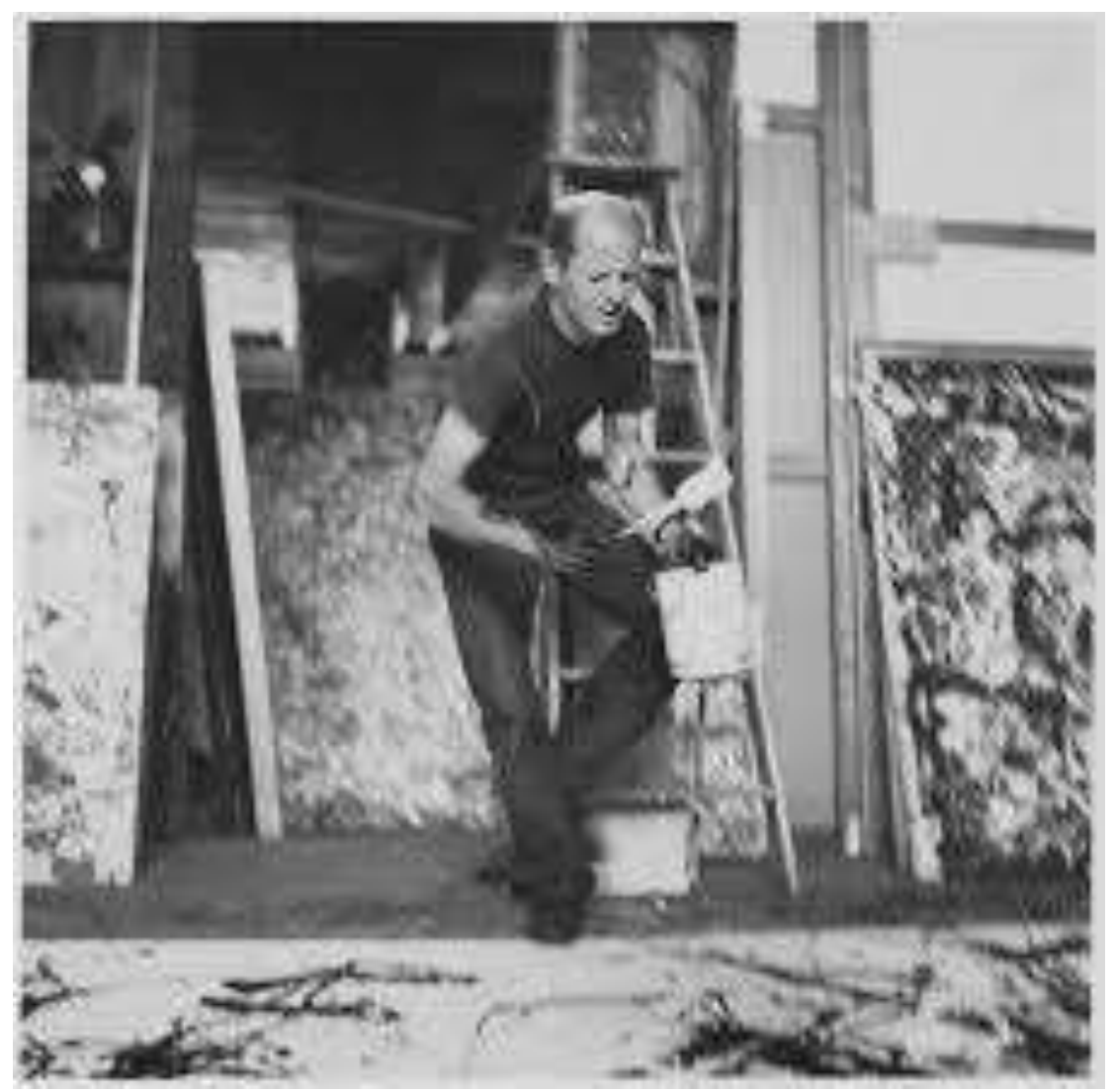

Figura 4: Jackson Pollock no trabalho em seu estúdio, 1950

Foto: Hans Namuth

Fonte: http://www.moma.org/explore/inside_out/2013/04/17/momas-jackson-pollock-conservation-projectinsight-into-the-artists-process

A esses desdobramentos que foram muitos, como o desenvolvimento da Perfomances, Happenings, Body art cada um de seu modo e com suas questões, voltaremos no próximo capítulo 2 no tópico 2.9 a comentar um deles: as performances realizadas para a câmera por ter relação direta com o uso das imagens em movimento no campo das artes visuais e por dar continuidade ao uso de materiais diversos como o corpo do artista. Observaremos, também, como essas obras foram exibidas.

Embora seja a partir de 1960 que o uso do audiovisual tenha sido ampliado por artistas, nós também trataremos no próximo capítulo da relação dos artistas com a imagem em movimento desde as vanguardas, que reivindicavam a ampliação "dos processos artísticos tradicionais através da mediação de dispositivos tecnológicos." (SANTAELLA, 2008 p. 154)

As tecnologias foram sendo agregadas fortemente ao campo das artes visuais; muitas obras instalativas utilizam da imagem em movimento e formas diversas de exibição dessas imagens em movimento. Santaella (2008, p.152), faz uma interessante passagem das técnicas à tecnologia no campo das artes. As técnicas, segundo ela, se referem a um saber fazer, a algo 
apreendido, desenvolvido, e afirma que as técnicas artísticas foram artesanais (feitas à mão) desde o Renascimento até a Revolução Industrial, quando surgem máquinas que ampliam a força humana e também possibilitam a produção de imagens, com a câmera fotográfica. Nascem as artes tecnológicas e ocorre o fim da exclusividade do artesanato nas artes.

Enquanto a técnica é um saber fazer, cuja natureza intelectual se caracteriza por habilidades que são introjetadas por um indivíduo, a tecnologia inclui a técnica, mas avança além dela. Há tecnologia onde quer que um dispositivo, aparelho ou máquina for capaz de encarnar, fora do corpo humano, um saber técnico, um conhecimento científico acerca de habilidades técnicas específicas. (SANTAELLA, 2008, p.152153) 


\section{Capítulo 2 Apontamentos nos usos de telas - do pré-cinema ao cinema expandido}

Começaremos este capítulo tratando brevemente das sombras chinesas que, segundo Sogabe (1990, p. 69), "talvez seja um dos primeiros meios de utilização física da luz para produção das imagens." Nas sombras chinesas as telas eram, segundo Sogabe (1990, p.69), um "tecido esticado sobre um chassi de bambu". Eram, também, translúcidas, de forma que o que os espectadores viam era invertido em relação àquilo que o operador de sombras fazia. Segundo o autor sobre a cabeça do manipulador de silhuetas era colocada uma lamparina que produzia as sombras na tela.

Passaremos agora para a câmara escura, e observaremos como as telas foram pensadas a partir desta.

Segundo Mannoni (2003, pp. 31-32), do século XIII à XVII as apresentações de projeções de imagens luminosas eram realizadas em salas às escuras para um público que olhava para uma tela branca. O princípio era o da câmara escura, que é o seguinte: realizando um furo em uma parede ou janela em uma sala escura, podemos observar dentro desta sala, objetos externos projetados na parede (tela) oposta deste orifício. A imagem fica mais nítida se essa tela for feita de lenço de papel ou de um pano branco. A distância da tela em relação ao orifício também altera a nitidez da imagem. Se a tela estiver próxima do orifício, a imagem

fica pequena e nítida; colocada mais distante deste orifício a imagem fica maior, porém, com menos definição. As imagens são vistas de cabeça para baixo e da esquerda para a direita.

Mannoni (2003, p.32) relata que o fenômeno observado na câmera escura da projeção dos raios luminosos era conhecido desde a Antiguidade. Aristóteles, não conseguiu explicar tal fenômeno, mas observou que o orifício de entrada do feixe luminoso poderia ter vários formatos além do circular e que ainda assim produzia uma imagem circular. Embora ainda sem explicação para tal fenômeno, câmaras escuras foram construídas, principalmente no século XIII. Segundo Mannoni (2003, p.32-33) um monge inglês Roger Bacon (1214-1294, retoma experimentos de Artistóteles em seu texto "De multiplicatione specerium [Da multiplicação das espécies], escrito em 1267, acrescentando-lhe um elemento importante: a presença de uma tela, uma parede (paries) sobre a qual os raios de luz incidiam."(MANNONI, 2003, p.32-33)

Aqui já se deduz, pela citação acima de Mannoni sobre os experimentos e observações de Roger Bacon e do fragmento mais acima sobre o tecido branco para maior nitidez da imagem, que a tela já era um elemento observado e importante, principalmente pela sua participação na nitidez da imagem. 
No século XIII a câmara escura era muito usada por cientistas para observação de eclipses e do sol, já que eram perigosos e danosos a olho nu. Data deste período a indicação de uso de superfícies planas como uma tábua, para a observação do eclipse em falas de Guillaume de Saint- Cloud em Potonniée ${ }^{7}$ apud Manonni (2003, p. 33):

\begin{abstract}
Faça uma abertura no telhado ou na janela de uma casa fechada, direcionada para a parte do céu onde aparecerá o eclipse, aproximadamente do tamanho do orifício que se faz um tonel para se extrair o vinho. Quando a luz do Sol entrar por essa abertura, coloque a uma distância de 20 a 30 pés do orifício alguma coisa plana, por exemplo, uma tábua, e verá que os raios de luz formam uma imagem circular sobre a tábua, mesmo se a abertura for angular.
\end{abstract}

Além desse uso (de observação do sol e eclipses) não se sabe se já no século XIII também utilizavam a câmara escura para observar o mundo exterior. " $\mathrm{O}$ uso da câmara escura para observação de objetos exteriores, e não apenas para estudos astronômicos, parece ter sido mencionado primeiramente nos escritos de Leonardo da Vinci (1452-1519)." (MANNONI, 2003, p. 34)

Leonardo, em seus estudos tanto de observação do sol quanto de imagens externas usava como tela uma folha de papel que ,segundo ele, deveria ser bem fina e olhada pelo verso:

"Estas imagens, quando provenientes de um lugar iluminado pelo sol, parecerão pintadas sobre o papel, que deverá ser bem fino e olhado pelo verso; e a pequena abertura deverá ser feita numa placa de ferro muito delgada." (Vinci ${ }^{8}$ apud Mannoni 2003, p.34)

Esta transparência obtida pelo papel fino possibilitava olhar a imagem atrás da tela, e assim observar a imagem restabelecida lateralmente embora ainda continuasse de ponta cabeça.

Outra indicação de utilizar um papel só que agora muito branco para maior nitidez viria de um italiano, Gerolamo Cardano, que revela segundo Mannoni (2003, pp.34-35) em seu livro De subtilitate [Das sutilezas], impresso em 1550, o processo de melhoria e modificação na câmara escura pela introdução da lente biconvexa (que aconteceu entre 1521 e 1550, antes disso do século XIII ao XVI o que variava na câmara escura era só se a abertura era feita numa parede ou janela), que possibilitou a nitidez das imagens ao concentrar os raios luminosos.

Se lhe agrada ver o que se passa na rua quando o Sol brilha, coloque um disco de

\footnotetext{
${ }^{7}$ Georges Potonniée, Histoire de la découverte de la photographie (reed. Paris: J-M. Place,1989), p.28.

${ }^{8}$ Léonard de Vinci, Carnets, trad. Louise Servicen, vol. I (Paris: Gallimard, 1987), p.238.
} 
vidro na janela, e estando a janela fechada, verá imagens projetadas através da abertura na parede oposta; mas as cores serão suaves. Coloque então um papel muito branco no lugar onde essas imagens incidem. (Potonniée ${ }^{9}$ apud MANNONI, 2003, p. 35)

Obs: Esse disco de vidro, presume-se, que seja a lente biconvexa. (MANNONI,,2003, p. 35),

Até aqui duas indicações de qualidades e usos visuais da tela: Leonardo indica a transparência da tela (do papel usado como tela) para observar as imagens em seu anverso e corrigir o sentido lateral da imagem. Em Gerolamo Cardano a indicação do muito branco é dada para maior nitidez das imagens.

Giovanni Battista Della Porta (1540-1615) descreveu a câmara escura na quarta e última parte de sua obra chamada Magiae Naturalis [Mágica natural] impressa em 1558 na qual trata das experiências catóptricas. ${ }^{10}$ Em uma nova edição que dividiu os textos em 20 partes, ele trazia, segundo Mannoni (2003, p 36), “a idéia de organizar um verdadeiro espetáculo óptico com a câmara escura [...]”, esse espetáculo escrito por Della Porta (1658) é citado por Mannoni (2003, p.36) e nessa citação, Della Porta indica que pode ser colocado diante da câmara escura paisagens, árvores, animais verdadeiros ou feitos com arte. Assim, os que estiverem na câmara não saberão se aquilo é real ou fictício. Della Porta ainda menciona nesse espetáculo na câmara escura o uso de panos brancos para visualização das imagens, os quais devem estar na parede oposta do furo na câmara escura.

Nesse espetáculo, Della Porta apresentava as imagens corretamente projetadas, devido a seu conhecimento desde 1558 das lentes de cristal e de espelhos. Assim, eram apresentados “atores de verdade, com cenários e música de acompanhamento.” (MANNONI, 2003, p.37)

Segundo o autor (2003, p. 37) Della Porta, desviou a vocação científica da câmara escura, tornando-a um "teatro óptico".

Aqui podemos observar uma analogia entre circuito fechado e as câmaras escuras, que apresentavam imagens "ao vivo" do que se passava fora delas. Havia, ainda, a escolha do local para se instalar uma câmara, que podia ser próxima a uma paisagem ou como visto e indicado por Della Porta, haveria a possibilidade de criar todo um cenário para ser apresentado na câmara escura. A tela apresentava assim imagens escolhidas ou criadas.

A câmara escura era vista com algum receio por parte de alguns cientistas e pesquisadores no que se refere a atribuição da magia dada a ela por charlatães àqueles que não

\footnotetext{
${ }^{9}$ Georges Potonniée, Histoire de la découverte de la photographie, cit., p.20; H. Gernsheim, The Origins of Photography, cit., p.10.

10 “A 'catóptrica' é a ciência dos efeitos ópticos por reflexão, especialmente com espelhos, em oposição à 'dióptrica' que lida com efeitos de refração, particularmente através de lentes.” (N. da ed.ingl.)

“(MANNONI, 2003, p.35)
} 
entendiam de óptica ou não tinham conhecimento daquela operação.

Segundo Mannoni (2003, p.39), os sábios condenavam o uso da câmara por “encenadores" inescrupulosos, mas recomendavam seu uso dessa para apresentar paisagens, rua movimentada etc. Faziam ainda comparações com a pintura, ressaltando a superioridade do movimento contínuo apresentado na tela da câmara escura. Como observado por duas citações:

Há sobretudo o prazer de ver o movimento dos pássaros, dos homens ou de outros animais, e a agitação das plantas sopradas pelo vento[...] Essa bela pintura, além de se apresentar em perspectiva, representa ingenuamente bem o que pintor algum jamais conseguiu imprimir em sua tela, a saber, o movimento contínuo de um lugar à outro (LEURECHON ${ }^{11}, 1621$, apud MANNONI 2003, p.39)

Os objetos de fora não transmitem apenas suas dimensões, formas e cores, mas também seus movimentos, que estão sempre ausentes nas telas dos pintores. (NICÉRON ${ }^{12}$ apud MANNONI , 2003, p.39)

Segundo Mannoni (2003, p.39), no século XVII, alguns pintores usam a câmara escura para criar as imagens para suas telas. Aqui observamos que uma tela influencia a outra e que a tela da câmara escura serve de decalque para a tela do pintor.

Este uso da tela da câmara escura, decalque de uma tela dinâmica a outra estática, pode ser ainda mais explorado com as câmaras escuras móveis. Em 1611, o astrônomo alemão Johannes Kepler (1571-1630) fez “ uma pequena tenda portátil”. Que podia ser transportada, montada em qualquer local e assim: "As imagens eram captadas sobre uma folha de papel no interior da tenda. Concluído o desenho, 'gira-se a tenda suavemente e enquadra-se uma nova vista da paisagem, podendo assim desenhar todo o horizonte'.(MANNONI, 2003, p.41). Os espelhos mágicos também eram utilizados, mas esses não atraíam tanto quanto as câmaras escuras. Esses espelhos transformavam o real em aberração. Segundo Bacon via Mannoni (2003, p.44), através de aparelhos especiais podem-se se construir coisas que na realidade não existem.

\footnotetext{
Podemos construir aparelhos e espelhos tais que a unidade seja multiplicada, que um homem pareça um exército, que se possa fazer surgir diversos sóis e diversas luas [...] Podemos também construir aparelhos onde os corpos são desenhados de tal modo que os maiores pareçam pequenos e reciprocamente, ou os que estão no alto apareçam abaixo, ou as coisas invisíveis se tornem manifesta ( $\mathrm{BACON}^{13}, 1893$, p.14 apud MANNONI, 2003, p.44)
}

\footnotetext{
${ }^{11}$ Jean Leurechon, Récréation mathématique (Pont-à- Mousson, 1621), pp. 98-99 e 103.

12 J.-F. Nicéron, La perspective curieuse, cit., pp. 21-22.

${ }^{13}$ Roger Bacon, De mirabili potestate artis et naturae (Paris: 1893),p. 14.
} 
O uso de espelhos também foi feito por Della Porta para conseguir uma "imagem suspensa no ar" e projetada tanto em paredes como no teto. Aqui se observa principalmente que já na câmara escura a imagem não tem apenas (embora ainda o faça com frequência) uma apresentação frontal, (como ocorre nos modos de exibição de imagens contemporaneamente). O teto, o chão e as paredes além da parede frontal também já eram utilizados para apresentação das imagens, como veremos nas duas citações abaixo:

Della Porta afirmava conseguir fazer aparecer uma "imagem suspensa no ar" com o auxílio de um espelho. Para isso colocava um espelho inclinado no soalho de uma câmara escura. Na parede oposta fazia uma abertura na forma de uma pirâmide truncada, com a extremidade mais estreita voltada para o espelho. Colocava nessa abertura piramidal uma imagem pintada sobre um papel ligeiramente transparente. $\mathrm{O}$ espelho captava a imagem (iluminada por trás pelo sol ou por uma fonte artificial) e a refletia no teto ou à parede. (MANNONI, 2003, p. 45)

Segundo Mannoni, Athanasius Kircher:

[...] afirmava fazer surgir pedras preciosas ('esmeraldas, piropo - liga de cobre e ouro- ,safiras, ametistas') no interior de uma câmara escura. Depois de fechar todas as janelas da câmara, ele abria um pequeno retângulo para deixar entrar os raios solares, que atravessavam cinco prismas de cristal dispostos horizontalmente num caixilho de madeira decorada. Os raios do espectro solar passavam então através de seis lentes cortadas em facetas e colocadas em círculo à volta de uma sétima lente de mesmo diâmetro. As facetas estilhaçavam os raios coloridos dos prismas, jorrando manchas multicores e brilhantes sobre a parede e o chão da câmera. (MANONNI, 2003, p. 47)

Espelhos também serviram de tela principalmente para "transformações catóptricas". Segundo Mannoni (2003, p.48) Kircher realizava essas transformações num aposento bem grande. A tela espelho ficava levemente inclinada (esta inclinação poderia ser alterada por uma corda) e instalada no alto da parede da sala. O espelho era iluminado pela luz frontal vinda de uma janela. O visitante adentrava esta sala e observava o espelho que refletia a cabeça de animais sobre seus ombros. Kircher conseguia esse resultado construindo e pintando, sobre cada lado de uma roda octogonal, oito cabeças de animais sobre um pescoço humano, que escondia em uma caixa aberta apenas na parte superior. A roda girava através de uma manivela e assim as imagens eram refletidas no espelho. 


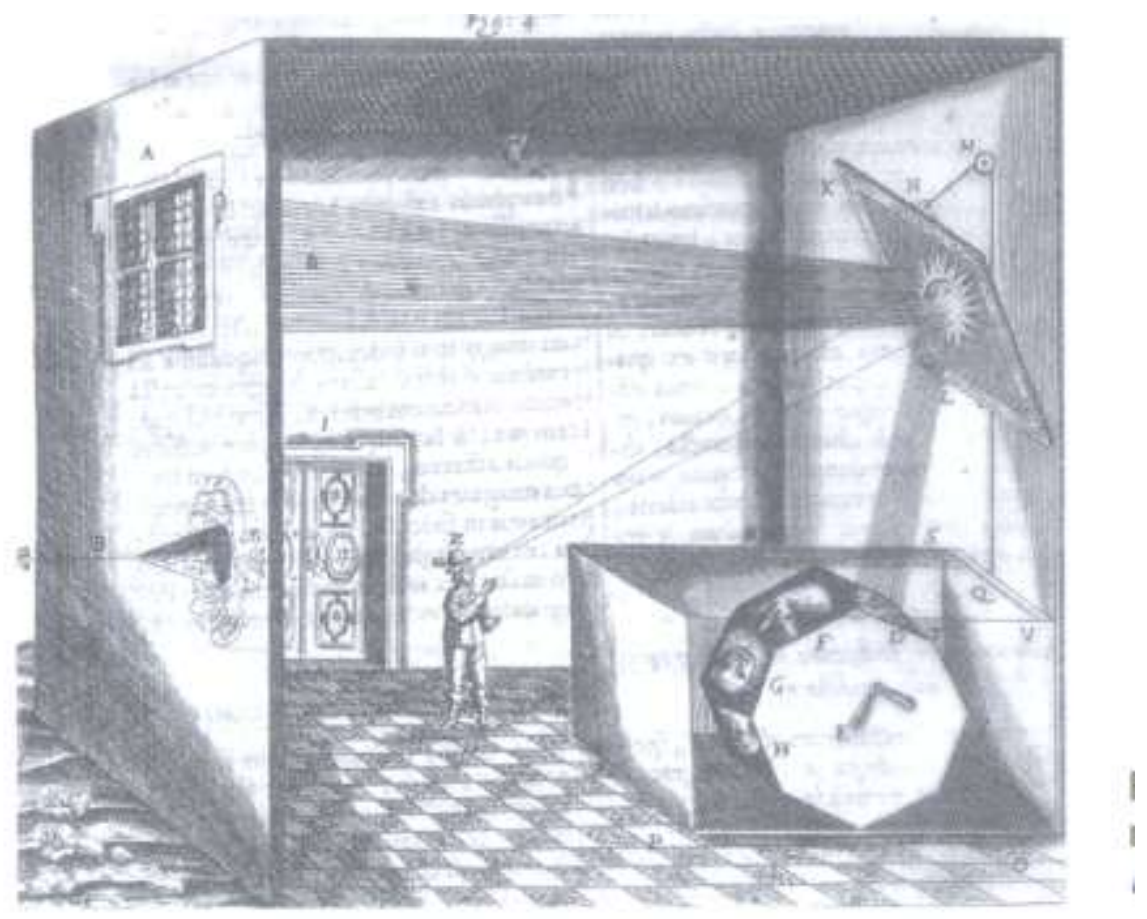

Figura 5: Athanasius Kircher, máquina de metamorfoses

Fonte: Fonte: MANNONI. Laurent. A grande arte da luz e da sombra: arqueologia do cinema. Tradução Assef Kfouri. São Paulo: Editora SENAC São Paulo: UNESP, 2003.p.48.

Da galeria dos ancestrais do cinematógrafo, nos detivemos um pouco na câmara escura e nos espelhos mágicos pelo nosso interesse em estudar como as telas eram aí pensadas e usadas. Deixamos de lado as criptologias de Kircher e outros assuntos que podem ser mais bem examinados no livro A grande Arte da Luz e da Sombra : arqueologia do cinema de Laurent Mannoni. Agora passaremos à lanterna mágica, focando ainda as telas.

\subsection{Lanterna mágica}

A lanterna mágica entra em cena efetivamente em 1659. Antes dessa data experimentos foram feitos, mas segundo Mannoni a lanterna mágica efetiva ocorre nesse ano. É batizada de lanterna mágica por volta de 1668, antes disso também era chamada de lanterna do medo.

Reinou por três séculos. Exibiu tanto imagens fixas como animadas. Chamou a atenção de sábios, artesões e charlatães. Expandiu-se por vários locais do mundo.

Mannoni $(2003,58)$ ressalta que a lanterna mágica teve pouca mudança do século XVII ao XIX. Trata- se de uma caixa óptica "que projeta sobre uma tela branca (tecido, 
parede caiada ou mesmo couro branco, no século XVIII), numa sala escurecida, imagens pintadas sobre uma placa de vidro.” (MANNONI, 2003, p. 58)

O maior empecilho na difusão da lanterna no século XVII, segundo o autor (2003, p.67), era a dificuldade gerada pela sua necessidade de lentes que ainda eram de complicada fabricação.

A lanterna mágica e a câmara escura são constantemente comparadas ou até inspiradas na pintura. Observamos por comentários de "espectadores", e até de sábios, esta comparação que em muitas vezes indica a superioridade da câmara escura em relação à pintura, pois ela apresenta imagens com perspectivas e com movimento, coisa que nenhum pintor jamais conseguiu fazer.

Com a lanterna mágica observamos que os desenhos das placas, além de serem realizados frequentemente por pintores, também tinham um referencial da pintura. Segundo Mannoni (2003, p.58), Cristian Huyges foi o inventor da lanterna mágica, e embora não fosse pintor, retirou a ideia de sua placa animada de uma pintura, Dança da morte, de Hans Holbein (1497-1543). (MANNONI, 2003, p.63)

As projeções com lanternas se espalharam em 1663. Richard Reeves, óptico inglês, e seu filho John se tornaram por volta de 1664 comerciantes de lanterna e realizavam apresentações do produto que vendiam na casa de ricos e sabemos, por relatos de pessoas como por um almirante chamado Samuel Pepys, que apresentações eram exibidas em salas escuras. "Reeves trouxe uma caixa, que ele fecha para mostrar como os raios de sol se recortam, e isso numa sala às escuras, com fumaça [...] Ele trouxe também uma lanterna com imagens sobre vidro, para fazer surgir coisas estranhas sobre a parede [...].(PEPYSs ${ }^{14}$ apud MANNONI, 2003, p.70)

O papel de lanternista de viajar de cidade em cidade, apresentando e exibindo imagens, foi popularizado por Thomas Rasmussen Walgenstein (um matemático de 1627-1681) por volta de 1664.

Os lanternistas ambulantes ficaram muito populares principalmente no século XVIII e cresceram em número, embora ganhassem muito pouco com tal trabalho. Para as apresentações e exibição de imagens levavam consigo: a caixa óptica ou a lanterna mágica, a tela branca e acompanhamento musical. Saíam às ruas gritando sobre as curiosidades a mostrar. O acompanhamento musical ficava as vezes a cargo de um auxiliar que usava uma sanfona ou um realejo.(MANNONI, 2003, p.97.)

\footnotetext{
${ }^{14}$ Samuel Pepys, Journal( Paris: Mercure de France, 1985),p. 261
} 
A tela como visto acima é móvel (carregam-na juntamente com o restante dos equipamentos). Quase sempre é um lençol ou pano branco. Em uma ilustração, de Michel Poisson, desenhada por volta de 1775, é mostrado um lanternista ambulante e a tela. "Pendurado a uma haste de ferro, um simples pano branco pende como um velho lençol: é a tela.” (MANNONI, 2003, p.99)

Embora a lanterna mágica dos ambulantes não tivesse tanta nitidez como outras lanternas mágicas mais sofisticadas, elas chamavam a atenção e ficaram populares. Os ambulantes lanternistas também usaram a lanterna mágica como arma do povo, um pouco antes e durante a Revolução Francesa. O repertório das lanternas incluía reinvindicações do povo, ataques violentos à realeza, etc. Essas projeções "tinham lugar numa sala fechada, provavelmente uma barraca de feira" (MANNONI, 2003, p.116)

A lanterna mágica e a câmera escura traçavam relações com a pintura e o desenho. Enquanto ainda não havia meios que possibilitassem gravar por processos químicos as imagens da câmara escura ou produzir por foto as imagens na lanterna mágica, era a pintura que ora era usada nas placas de vidro da lanterna mágica ora era o desenho-base para uma pintura, usado como decalque numa tela inserida na câmara escura que servia como registro para o que nela era visualizado. Ainda a mão do desenhista, pintor era fundamental.

\subsection{Fantasmagoria}

No final do século XVIII, cientistas e mágicos criaram a fantasmagoria, um novo gênero de espetáculo luminoso, com algumas diferenciações em relação aos espetáculos comuns de lanterna. Dentre elas daremos ênfase às telas usadas na fantasmagoria, espetáculo luminoso que difere, segundo Mannoni (2003, p.151), das apresentações anteriores de lanterna em alguns pontos:

O equipamento de projeção ficava escondido, atrás da tela. Um fantasma era apresentado aumentando ou diminuindo de tamanho na tela, (esta a principal diferença entre a fantasmagoria e o simples espetáculo de lanterna mágica). As vistas apresentadas eram animadas e móveis. Foi inventada uma encenação macabra para a apresentação do espetáculo com o intuito de causar angústia e mal-estar nos espectadores. Sons de marimba de vidro ou graves "fantasmagóricos" iniciavam o espetáculo.

A fantasmagoria coincidiu com o prestígio da literatura gótica e isto era "uma estranha 
perversão do racionalismo científico das Luzes, que em muito contribuiu para o aperfeiçoamento da lanterna.” (MANNONI, 2003, p.151)

Telas diferentes das vistas até agora, paredes, panos, lenços e papéis foram usadas em alguns desses espetáculos. Johann Schröpfer, o "criador de fantasmas", realizou sessões em 1774, aproximadamente, nas quais trazia fantasmas de pessoas desaparecidas por meio da "lanterna nebulosa". Essa lanterna não era usada para projetar imagens sobre pano tradicional, mas sobre cortina de fumaça e foi descrita por Edme-Gilles Guyot em 1769-70. Segundo Mannoni ,para conseguir a projeção na fumaça;

\section{Guyot usava uma espécie de braseiro, com o feixe da lanterna dirigido para a fumaça [...] Guyot também conseguia fazer surgir " um fantasma sobre um pedestal", graças a uma pequena lanterna mágica escondida numa arca de madeira. As vistas eram projetadas sobre um espelho inclinado, que refletia as imagens sobre a tela de fumaça, produzida por um simples escalfador colocado sobre a arca. (MANNONI, 2003, p.153 )}

Nesse espetáculo a tela era diferente da habitual e tal característica levaria a alguns processos e observações para o funcionamento da apresentação. Pelo material, pelo movimento da tela, deduz-se que era necessário controlar a quantidade e a direção da fumaça.

Christlieb Benedict Funk, um professor que descreve o sistema nebuloso de Guyot, em 1783 afirma que o mais difícil deste procedimento era o direcionamento e produção da fumaça. (MANNONI, 2003, p. 153)

Se a fumaça não fosse controlada e se espalhasse, "não apenas os olhos dos espectadores não agüentariam suportá-la mais de 5 a 8 minutos, mas a própria aparição logo se desvaneceria". (Funk ${ }^{15}$ apud MANNONI, 2003, p. 153)

Outros métodos para tentar corrigir qualquer distorção na imagem quando apresentada nestas superfícies (fumaça) também apareceram. Johann Samuel Hale, que também descreve o sistema de Guyot, em 1784 apresenta sua descrição nela acrescentando algumas indicações: a projeção tinha que ser realizada obliquamente e por essa razão, deformava (alongava) a imagem na fumaça. Para evitar a deformação ele indicava pintar o espírito em miniatura sobre o vidro.

De acordo com o relato de Halle, possivelmente ele teria assistido a alguma apresentação de Johann Schröpfer ,pois sua descrição se assemelhava a suas sessões. Através da descrição que Halle faz do espetáculo, é possível observar alguns pontos em comum com as obras audiovisuais contemporâneas.

\footnotetext{
${ }^{15}$ Christlieb Benedict Funk, Natürliche Magie, oder Erklärung Verschiedner Wahrsagerund Natürliche Zauberkünste (Berlim, 1783), p. 152
} 
O pretendido mago conduz o grupo de curiosos a um ambiente revestido de um pano negro, e no qual se acha um altar pintado também de negro, com dois candelabros e uma cabeça de morto, ou uma urna funerária. $\mathrm{O}$ mago traça um círculo na areia, em volta da mesa ou do altar, e pede aos espectadores que não atravessem o círculo. Ele começa sua conjuração, lendo num livro e fazendo fumaça com uma substância resinosa para os bons espíritos e com coisas fétidas para os maus. Num único golpe as luzes se extinguem por si mesmas, com um forte ruído de detonação. Nesse instante, o espírito invocado aparece pairando no ar, por cima do altar e da cabeça da morte, de tal maneira que parece querer alçar vôo pelos ares ou desaparecer debaixo da terra. O mágico passa a sua espada diversas vezes através do espírito, que lança um grito lamentoso. O espírito, que parece elevar-se da cabeça da morte numa ligeira nuvem, abre a boca; os espectadores vêem então abrir-se a boca da cabeça da morte e ouvem as palavras pronunciadas pelo espírito defunto, num tom rouco e terrível, quando o mágico lhe faz perguntas.

Durante toda essa cerimônia, relâmpagos rasgam o ambiente... e ouve-se um ruído terrível de tempestade. Pouco depois os candelabros acendem-se por si sós, enquanto o espírito desaparece, e seu adeus agita de maneira sensível os corpos de todos os membros da platéia... A sessão mágica chega ao fim, enquanto cada qual parece perguntar ao vizinho, com um palor lívido no rosto, que julgamento deve fazer a respeito desse encontro com o mundo subterrâneo. Johann Samuel Halle ${ }^{16}$, apud MANNONI, 2003, pp 154-155).

Observamos que a fantasmagoria envolvia não apenas a visão, mas o corpo todo pelos efeitos sonoros que são relatados, pelos choques que eram resultados de descargas elétricas no corpo de todos os espectadores. O espaço em que ocorria tal apresentação era todo encenado e sendo assim era parte importante da obra. Era uma instalação. Cheiros também eram explorados nessas sessões. Há uma interatividade e uma ação performática do apresentador com a imagem, já que ele (o mago), além de falar ao vivo, dar instruções e fazer toda uma preparação no local, ainda passa a espada no espírito que interage com tal ato, respondendo ao vivo, com gritos lamentosos. Esses processos de incorporação de sensações, ambientação são usuais em instalações contemporâneas em geral e também nas ligadas a imagem em movimento.

Segundo Mannoni (2003, p. 155), todos esses efeitos, truques que estão relatados por Halle vão ser continuados por Robertson com exceção da eletrocução do público. Será também acrescentado um componente técnico importantíssimo para o espetáculo de fantasmagoria: "a imagem retroprojetada, que avança ou recua, diminuindo ou aumentando, e sempre nítida." (MANNONI, 2003, p. 155)

Essa nitidez foi possibilitada, diz Mannoni (2003, p.158), pelo foco ajustável da objetiva.

Ainda segundo o autor (2003, p.156) embora seja Paul Philidor o inventor da retroprojeção móvel é com Étienne- Gaspard Robert, conhecido como Robertson, que esta fica mais conhecida. A retroprojeção móvel é um dos componentes principais de diferenciação

\footnotetext{
${ }^{16}$ Johann Samuel Halle, Magie: Oder die Zauberkräfte der Natur (Berlim: J. Pauli, 1784), pp.232-233
} 
da fantasmagoria do restante dos espetáculos de lanterna com vistas de fantasmas. Este componente foi tão importante que alterou:

[...] o quadro, a perspectiva e o espaço cênico da projeção. O desfile tradicional de
imagens, em uso desde Huygens, foi abandonado: agora figuras luminosas e
animadas atravessavam à tela em todos os sentidos, surgindo do fundo dela e vindo
em direção ao espectador numa velocidade estonteante, para subitamente
desaparecerem. A conjugação da lanterna móvel com a placa animada representou
um passo essencial na história da projeção "movimentada". (MANNONI, 2003,
p.155)

Philidor trabalhava com retratos e prometia aos interessados o aparecimento de entes queridos durante as sessões que realizava com horários definidos. Às vezes ocorriam duas delas num mesmo dia. Ele também contratava e trabalhava para isso com pintores para obter o máximo de fidelidade dos entes; quase sempre conseguia um retrato do desaparecido e assim o pintor contratado podia pintar o retrato que seria apresentado em tamanho natural nas sessões. O espetáculo era um elo entre os vivos e os mortos. Philidor não pretendia enganar já que revelava, antes mesmo do início da apresentação, que o que apresentaria não seriam espíritos, mas que produziria "[...]diante de vós simulacros e figuras, tais como supomos serem os espíritos, nos sonhos da imaginação ou nas mentiras dos charlatães.[...]" (Philidor apud MANNONI, 2003, p. 158)

Além dos mortos, também havia projeções de vivos, segundo Mannoni (2003, p. 159), como aconteceu a um jornalista que vê diante de si sua própria imagem em uma das sessões. Étienne-Gaspard Robert, conhecido como Robertson deu continuidade a esses efeitos, truques, de Philidor. Ele escondia o projetor atrás da tela, usava de aumento e diminuição da imagem até sua desaparição repentina. Além dessa preocupação com efeitos, como esconder o projetor etc, observamos em uma fala de Robertson sua preocupação com a tela e seu preparo:

Adquiri um lençol de três varas de largura, ${ }^{* 17}$ de modo a não precisar de costura, e, a
fim de torná-lo translúcido, mandei fundir cera bem branca e pura, dentro da qual o
imergi no momento de fervura; imediatamente depois, eu o preguei na abertura feita
na parede e, passando-lhe gradualmente um rescaldo bem aceso, espalhei a cera, que
deu à minha tela a transparência que buscava a muito tempo." (ROBERTSON ${ }^{18}$
apud MANNONI 2003, p.167)

Pela citação acima, inferimos que as qualidades físicas da tela, como estamos dando ênfase em todo o nosso texto, são importantes para a apresentação das imagens. A preocupação no modo de preparo relatado por Robertson é evidente e podemos também observar que a qualidade de translucidez é um recurso visual que Robertson buscava e que se

\footnotetext{
$17 *$ cerca de 3,5 m. (N, da ed. ingl).

${ }^{18}$ Étienne-Gaspard Robertson, patente francesa n 109, de 17 de março de 1799 (vencida em 17 de março de 1904).
} 
aproxima da preocupação no preparo da tela das artes visuais.

Robertson fazia suas apresentações fantasmagóricas no Pavillion de L’Échiquier na Rue de L'Echiquier em 1798. Era um castelo pequeno e ele ocupava o primeiro andar deste para suas apresentações (MANNONI, 2003, p. 163).

Robertson chamava uma pessoa para tocar harmônica isto é, um “instrumento constituído de uns trinta copos de vidro, dispostos horizontalmente sobre um eixo rotativo, acionado por um pedal. A pressão dos dedos sobre o vidro produzia um som muito estranho." (MANNONI, 2003, p.164)

Robertson a partir dessas apresentações foi excluído da comunidade da ciência, pois, ligava-se a charlatães e ilusionistas. Os parisienses iam ao Pavillion "para se divertir, para sentir calafrios e não para serem instruídos.” (MANNONI, 2003, p. 165)

Sendo esse Pavillion pequeno (no máximo cabiam 60 pessoas) Robertson escolheu outro local para suas apresentações por volta do final de 1798: O Convento dos Capuchinos, local fúnebre, perfeito para a fantasmagoria.

Robertson também escreve cenas como se fossem roteiros atuais, com indicações precisas de encenações etc. Ele descreve bem esses "roteiros" em seu livro chamado Mémoires. As projeções também eram mais longas que os primeiros filmes. (MANNONI, 2003, p.174-175).

Robertson utilizava também mais de uma lanterna: uma fixa projetava um cenário e outra móvel, os personagens. Robertson possivelmente as usou para "fazer fusões encadeadas por meio de diafragmas; a imagem se desvanece lentamente, para gradualmente dar lugar a uma outra (esse método só aparecerá publicamente em 1839, na Inglaterra).” (MANNONI, 2003,p.176)

No inicio das apresentações de Robertson (enquanto a luz ainda estivesse acesa)a tela ficava escondida por uma cortina que exibia uma pintura de um túmulo, logo que a sala ficasse na escuridão essa cortina se erguia. (MANNONI, 2003, p. 180)

Diversas outras salas foram abertas para a apresentação da fantasmagoria. 


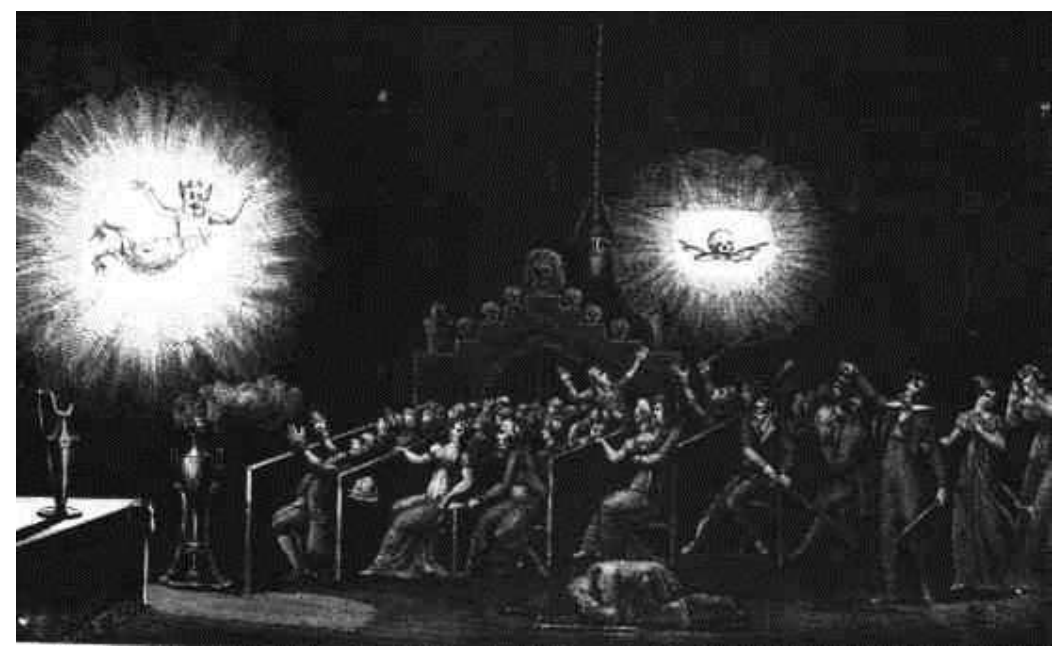

Figura 6: Robertson. Fantasmagoria

Fonte: http://www.magiclantern.org.uk/history/history6.html

\subsection{As telas nos Panorama, Dioramas e brinquedos ópticos}

Continuando nosso estudo com foco nas telas daremos ênfase em telas que embora nem sempre recebam projeção, isto é, são pinturas que podem ser trabalhadas com efeitos de luz, de iluminação ou não, tenham semelhanças em seu formato, tamanho e apresentação com telas que foram utilizadas posteriormente para apresentação de imagens em movimento (como veremos nesta dissertação quando tratarmos do primeiro cinema, com destaque as apresentações de imagens em movimento na Exposição Universal de Paris em 1900) e também nas telas contemporâneas, que encontramos no cinema de exposição em festivais de arte eletrônica, de arte interativa, em ambientes urbano que diferem das telas do cinema de sala de exibição. Desta forma, observamos que os formatos e disposição das telas de pintura influenciaram algumas formas de apresentação das imagens em movimento, isto é, as que se afastam da exibição tradicional do cinema de sala.

Começaremos com o Panorama que trabalha principalmente na disposição, tamanho da tela e imersão dos espectadores. O Panorama "é um gigantesco dispositivo imagético (muitos panoramas tinham uma tela de mais de mil metros quadrados)." (PARENTE, 2009, p. 34). Esta tela era quase sempre uma pintura "realista", feita com a técnica do chiaroscuro, e em perspectiva. A tela era disposta e estendida em uma parede circular. A iluminação da tela vinha do alto (geralmente do teto ou de uma abertura) principalmente no início dos panoramas. O panorama foi patenteado pelo pintor Robert Barker em 1787. [...] uma invenção inteiramente nova [...], com o fim de apresentar vistas da natureza em grande formato, através da pintura a óleo, afresco, aquarelas, creions, ou de qualquer outro modo de pintar ou 
desenhar. (BARKER ${ }^{19}$, apud MANNONI, 2003, p.188)

Os espectadores podiam observar a pintura ininterrupta situados em uma plataforma central a alguma distância da tela. Para o espectador tomar contato com a sala, espaço onde se encontrava a tela, deveria passar por "corredores sombrios, antes de chegar diante do quadro circular vivamente iluminado, um efeito-surpresa que era em grande parte responsável pelo sucesso do panorama.” (MANNONI, 2003, p.188)

Estas vistas panorâmicas representavam paisagem, batalhas etc. $\mathrm{O}$ espectador posicionado no centro, destas vistas se sentia imerso na paisagem ou cena representada.

Ao panorama de Barker, ainda segundo Mannoni (2003, pp.190-191), Robert Fulton acrescenta em seu pedido de patente o movimento da pintura através do enrolamento de oito telas em cilindros verticais. Movendo e deslizando estas pinturas sobre uma estrutura de ferro em volta da rotunda, as vistas seriam movimentadas e as pessoas poderiam viajar para vários locais sem se moverem. Desta forma as telas eram móveis.

Outros aperfeiçoamentos foram acrescentados ao panorama de Barker: os panoramas poderiam ser vistos à noite, através da iluminação com lâmpadas a óleo.

As ideias de Fulton nunca foram efetivamente concretizadas, por problemas financeiros, por exemplo, não teve financiamento para construção da rotunda, motivo pelo qual ele cede seus direitos a James Thayer e sua esposa, Henriette Beck.

James Thayer fez sociedade com o pintor, Pierre Prévost, que tinha um estilo clássico e criou pinturas de 100 a 120 m para os panoramas de Thayer. Este constrói seu panorama próximo a fantasmagoria de Robertson e por volta de 1799 inicia as apresentações. Robertson não gosta da ideia já que o panorama era visto como arte, e a sua fantasmagoria era vista como espetáculo duvidoso. (MANNONI, 2003, p.191)

Por algumas modificações simples, como variar levemente o edifício de apresentação das telas contínuas e pintadas ou o maquinário usado, já se mudavam os nomes e eram exigidas novas patentes como por exemplo, o Cosmorama em 1808/ Mareorama etc.

Em 1822 aproximadamente surge o Diorama um espetáculo inventado por Louis Jacques Mandlé Daguerre (1787-1851) inventor do processo fotográfico chamado daguerreotipo em 1839, e Charles Marie Bouton (1781-1853). Os dois inventores eram

\footnotetext{
${ }^{19}$ Robert Barker, patente britânica n 1.612, 19 de junho de 1787, "Apparatus for Exhibiting Pictures", O texto completo dessa patente foi reimpresso na edição de Laurent Mannoni et al. (orgs.), Light and Movement: Incunabula of the Motion Picture 1420-1896 (Gemona: Cineteca del Friuli/Le Giornate del Cinema Muto, 1995), pp. 157-158.
} 
pintores e Daguerre tinha experiência com teatro. Resolveram, em 1822, unir métodos cenográficos do teatro ao panorama, unindo a essa junção efeitos especiais das caixas ópticas e mudanças de luz. (MANNONI, 2003, p.196)

No diorama as telas eram de percal, ou algodão. Pintadas dos dois lados, e mediam 22 $\mathrm{m}$ de largura por $14 \mathrm{~m}$ de altura. A tela trabalhava um mesmo tema de dois lados, produzindo maior visibilidade ora de um lado ora de outro, controlando esta visibilidade pela alteração da luz do espaço onde ela se encontrava, através da abertura de janelas ou quando o teto envidraçado era tapado.

[...] pintava-se uma paisagem diurna, iluminada pela luz natural vinda do alto, através de grandes painéis envidraçados no teto. No outro lado da tela, detalhes da mesma paisagem eram realçados a tinta, para criar o efeito noturno: a lua, manchas de escuridão, lanternas iluminadas, etc. Quando os painéis envidraçados do teto eram tapados e outras janelas atrás da tela abertas, os efeitos noturnos subitamente surgiam da cena diurna, em fusão encadeada.” (MANNONI, 2003, pp.197-198)

As telas eram dispostas na rotunda e ficavam fixas, podiam ser observadas a $13 \mathrm{~m}$ de distância. Entre a tela e os espectadores eram inseridos animais vivos, cenários. Cada tela era apresentada durante um quarto de hora. O auditório podia girar sobre seu eixo.

Augustin Haton, em seu pedido de patente, acrescenta ao diorama um método para animar as vistas. O método consistia em "deslizar um objeto sobre trilhos através da pintura estática." (MANNONI, 2003, p.199). Combinava este movimento com as usuais alterações da luz usadas nos dioramas.

Os dioramas foram diminuindo por volta de 1839.
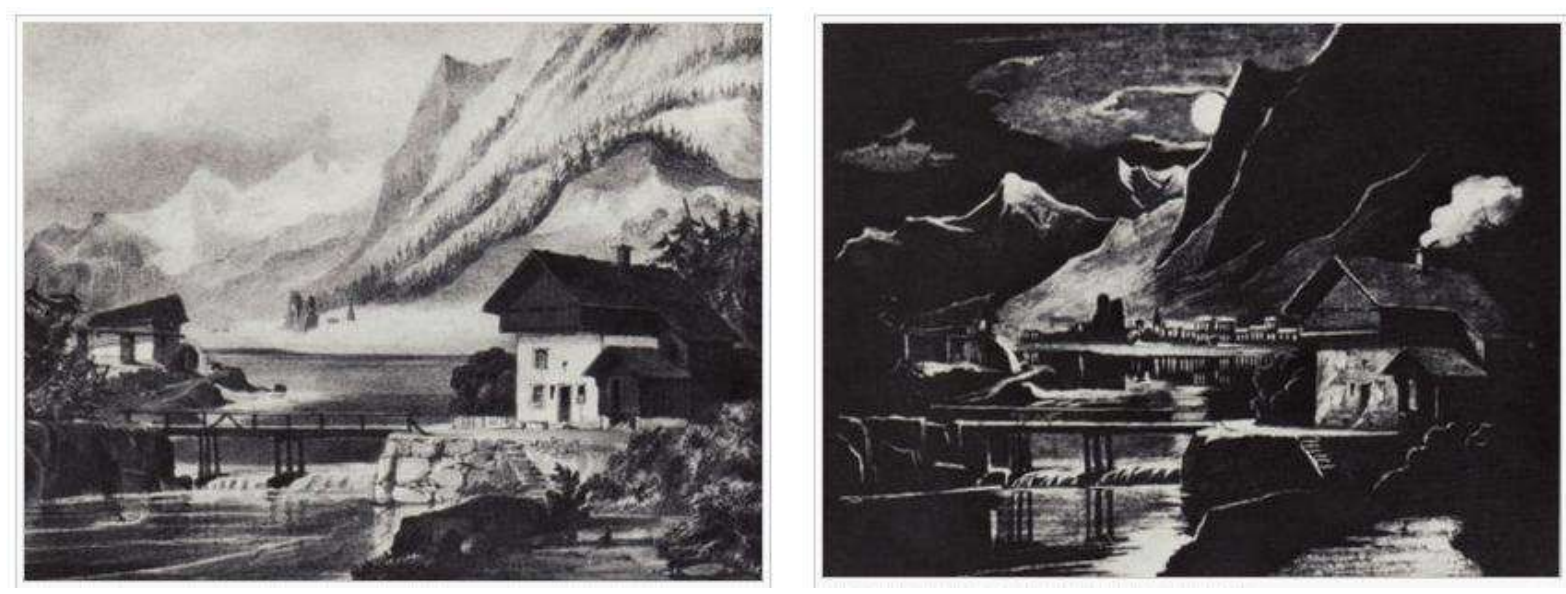

Figura 7: Diorama

Fonte: http://janeaustensworld.files.wordpress.com/2011/11/diorama-night_day.jpg

Antes, aproximadamente em 1820, intensificam-se as pesquisas relacionadas à 
persistência das imagens na retina. Muitos pesquisadores pretendem contar o tempo em que as imagens se formam e ficam retidas em nossa retina. Nesse período são retomadas experiências mais antigas e muitas experimentações foram realizadas. Pesquisadores como Joseph Plateau utilizam para ilustrar essas pesquisas, os chamados "brinquedos ópticos", que também foram comercializados. Deste pesquisador foram comercializados dois brinquedos: o anortoscópio concebido em 1828 e comercializado em 1836, e o fenaquistiscópio concebido em 1832 e posto a comercialização em 1833. No anortoscópio era usado um disco de papel oleoso como suporte de uma imagem anamórfica e curva que girava em torno de seu eixo. $\mathrm{Na}$ frente deste papel, era colocado outro disco preto com quatro fendas, que girava em direção contrária e numa velocidade menor do que a do outro disco.

Se observássemos o aparelho do lado do disco preto veríamos a imagem estática e corrigida. $\mathrm{O}$ anortoscópio usava como tela ${ }^{20}$ um disco em movimento e a tela aqui era circular e móvel. No fenaquistiscópio a tela de visualização das imagens é um espelho. Este aparelho é um disco pintado com figuras em posições diferentes (com leves alterações de movimento) separadas regularmente entre si. O aparelho deve ser posicionado de frente a um espelho e deve estar em rotação. Neste disco existem fendas das quais se deve olhar através delas e assim observar imagens animadas no espelho.

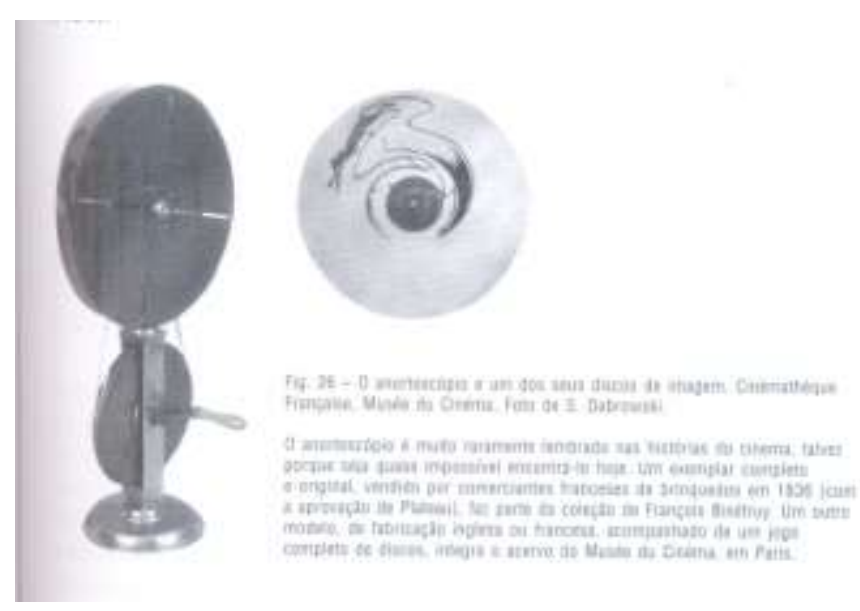

Figura 8: O anortoscópio e um dos seus discos de imagem.

Fonte: MANNONI. Laurent. A grande arte da luz e da sombra: arqueologia do cinema. Tradução Assef Kfouri. São Paulo: Editora SENAC São Paulo: UNESP, 2003.p.217.

\footnotetext{
${ }^{20}$ Consideraremos aqui a tela a superfície de observação das imagens
} 


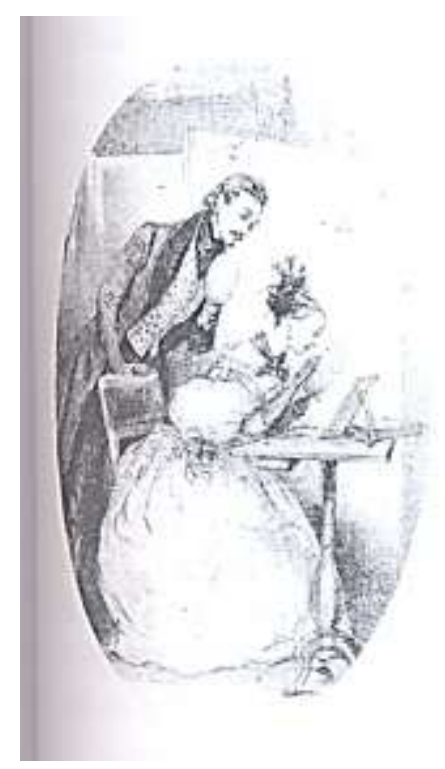

Figura 9: O fenaquistiscópio

Paul Gavarni, litografia intitulada o fenaquistiscópio

Fonte: MANNONI. Laurent. A grande arte da luz e da sombra: arqueologia do cinema. Tradução Assef Kfouri. São Paulo: Editora SENAC São Paulo: UNESP, 2003.p.225.

Segundo Mannoni (2003, pp.235-237), posteriormente foi introduzida a lanterna mágica no fenaquistiscópio. Esta nova invenção foi chamada de dinascópio, tendo sido desenvolvida por Augustín Gómez Santa Maria. A partir de então pôde ser projetado, usandose uma tela como suporte. Outros equipamentos utilizaram o espelho como tela. Dentre eles o estereoscópio-fantascópio, ou bioscópio de Jules Duboscq, de 1852. O funcionamento deste equipamento é segundo Mannoni, (2003, p.245) semelhante ao fenaquistiscópio. Em um disco em movimento observam-se, por fendas, as imagens (neste caso fotografias estereoscópicas) por reflexão, em espelhos.

Henri Robin que realizava o teatro óptico, usava espelhos (escondidos) e telas transparentes no palco para que contracenassem pessoas fora do palco (escondidas) por processos de reflexão com outras no palco. Esse processo também foi utilizado por John Henri.

Embora nas chamadas "aparições espectrais" a tela (placa de vidro) não seja o único elemento importante, possibilita, juntamente com o trabalho da luz e de reflexão, a aparição de espectros, frequentemente apresentados em teatros. Nestes teatros as apresentações são realizadas no palco contracenando ator de verdade com o espectro de outro ator de verdade, fora do palco em tempo real. Através dessas placas e de iluminações os espectros parecem vivos. Henri Robin um lanternista e mágico realizava muitas dessas apresentações segundo 
seu próprio relato por volta de 1847. Mas essas aparições se tornaram ainda mais populares nas mãos de John Henry Pepper e Henry Dircks (MANNONI, 2003, p. 253).

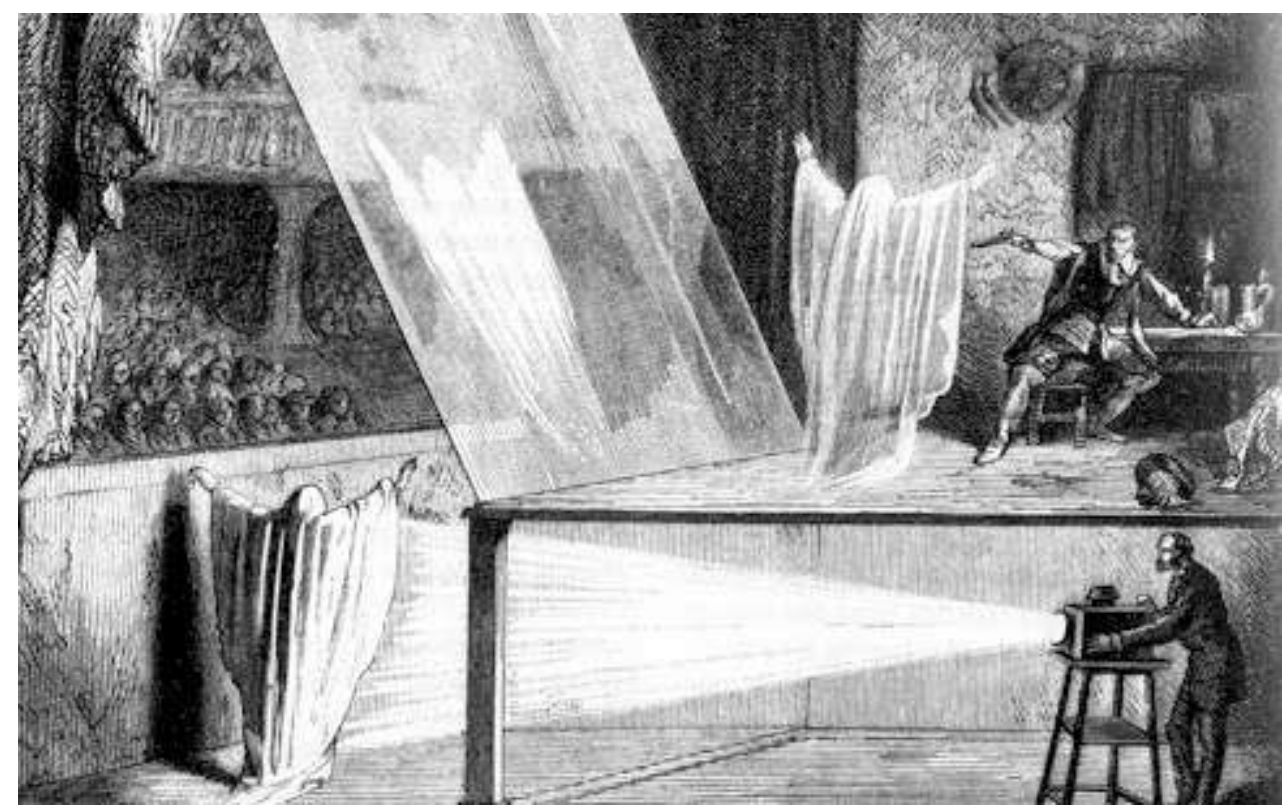

Figura 10: John Henry Pepper. Pepper's Ghost. 1862

Fonte: http://www2.derby.ac.uk/dmarc/conferences/digital-hybridity/tags/Pepper\%E2\%80\%99s-Ghost/

Dessa forma, observamos que, embora fossem técnicas diferentes, a imagem em tempo real e imagem projetada já estavam sendo usadas no teatro. Nessa época, como acontece contemporaneamente, imagens são projetadas e atores no palco contracenam, prática comum em muitos trabalhos de cinema expandido. As tecnologias atuais são diferentes e mais sofisticadas do que as que existiam anteriormente, isto é, na contemporaneidade temos recursos tecnológicos para apresentação tanto de imagens gravadas ou ao vivo. São, sem dúvida, técnicas que diferem bastante das realizadas anteriormente, conseguidas através de espelhos, projeção e placas de vidro.

Vejamos mais um aparelho que utiliza espelhos móveis como tela, o praxinoscópio, tinha o mesmo objetivo dos outros aparelhos como o fenaquistiscópio e o zootrópio. Também mostrava imagens em movimento, apenas utilizava outro método para isto. É um aparelho com uma série de espelhos colados lado a lado e fixados de modo a formar um polígono prismático e inseridos no centro de um tambor de diâmetro maior. Uma tira de papel era adicionada na face interna do tambor maior e o número de desenhos neste papel correspondia ao número de espelhos (em geral 12). Tais desenhos tratavam de um mesmo assunto com pequenas diferenças de movimento. (MANNONI, 2003, p. 362)

O tambor ficava apoiado sobre uma base de madeira que podia ser girada juntamente 
com o polígono. Desta forma, os desenhos eram visualizados em movimento nesses espelhos móveis (embora também se possa olhar diretamente para os desenhos). Do praxinoscópio Reynauld fez aparelhos derivados como o praxinoscópio-teatro, uma caixa óptica na qual os personagens, figuras litografadas, se movem com o movimento giratório do tambor e dos espelhos e são visualizadas como se estivessem no cenário, que é colocado na frente da caixa e visto por reflexão (por um espelho). O espectador observava com os dois olhos as imagens, o cenário através de uma abertura retangular. Os cenários podem ser trocados pelos espectadores. Esses escolhem o cenário e decidem se uma "menina que pula corda pode se divertir numa sala ou numa pequena floresta, diante de um casal que a olha tão encantado quanto nós outros." $\{\ldots\}$ (MANNONI 2003, p.366 )

O-pião-fantoche derivado do praxinoscópio também tinha espelhos como tela. Este aparelho:

\footnotetext{
Consistia em quatro espelhos triangulares, inclinados a 45 graus e unidos de modo a formar uma pirâmide truncada. No ápice da pirâmide colocava-se um pequeno disco de cartão com quatro imagens impressas, representando estágios de um movimento. Quando se girava a pirâmide (montada sobre um pedestal de madeira), os reflexos das quatro fases do movimento se tornavam visíveis no espelho móveis. (MANNONI, 2003, p.366)
}

Ao praxinoscópio Reynould também acrescentou um aparelho de projeção, criando assim o que chamou de praxinoscópio de projeção. Este aparelho exibia as imagens em tela de tecido branco.

Do praxinoscópio de projeção também derivou o teatro óptico patenteado em 1888. A diferença deste aparelho em relação ao praxinoscópio de projeção é que no teatro óptico as imagens não ficavam em looping, elas não eram repetidas e tinham duração bem mais longa. Para possibilitar essa maior duração das imagens utilizava uma fita flexível que se enrolava e desenrolava em um carretel. O próprio Reynauld exibia em 1892, o espetáculo no MuséeGrevin (museu de figura de cera). Reynauld podia alterar a sequência das imagens apresentadas, isto é, podia apresentar as tiras de imagens fazendo-as ir para a frente ou para trás, a seu gosto. As imagens eram projetadas por reflexão dos espelhos para uma tela de tecido branco. Todo o processo era escondido do público e para isto Reynauld trabalhava com retroprojeção. O espetáculo empregava também efeitos acústicos.

Outros aparelhos concebidos e batizados por Henry-Désire Du Mont de omniscópios, em 1859, derivados do fenaquistiscópio apresentavam imagens em tela de vidro fosco, dentre outras. (MANNONI, 2003, p.257) 


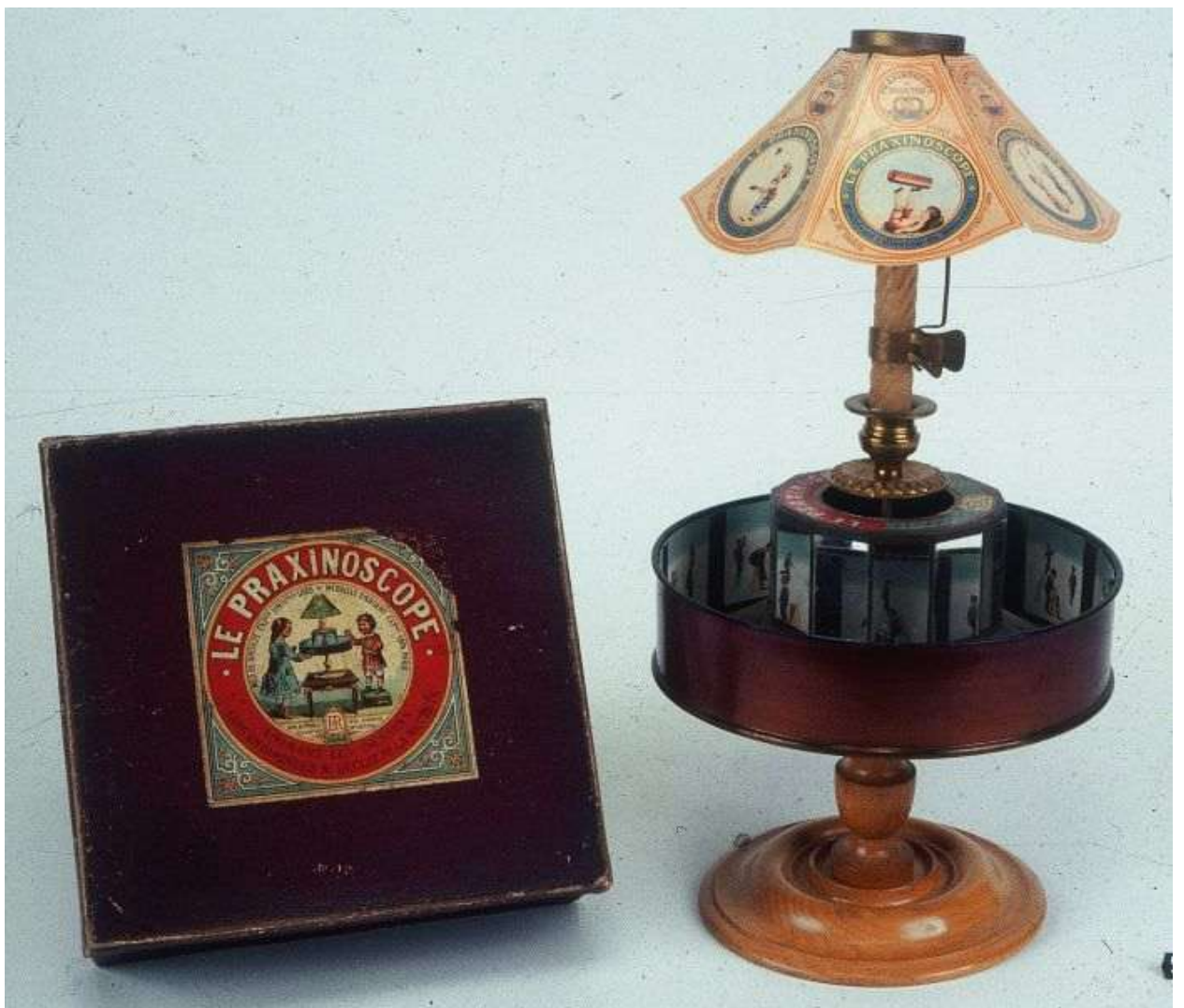

Figura 11: Praxinoscópio

Fonte: http://www.museudelcinema.cat/esp/colleccio_objectes.php?idcat=646\&idreg=907

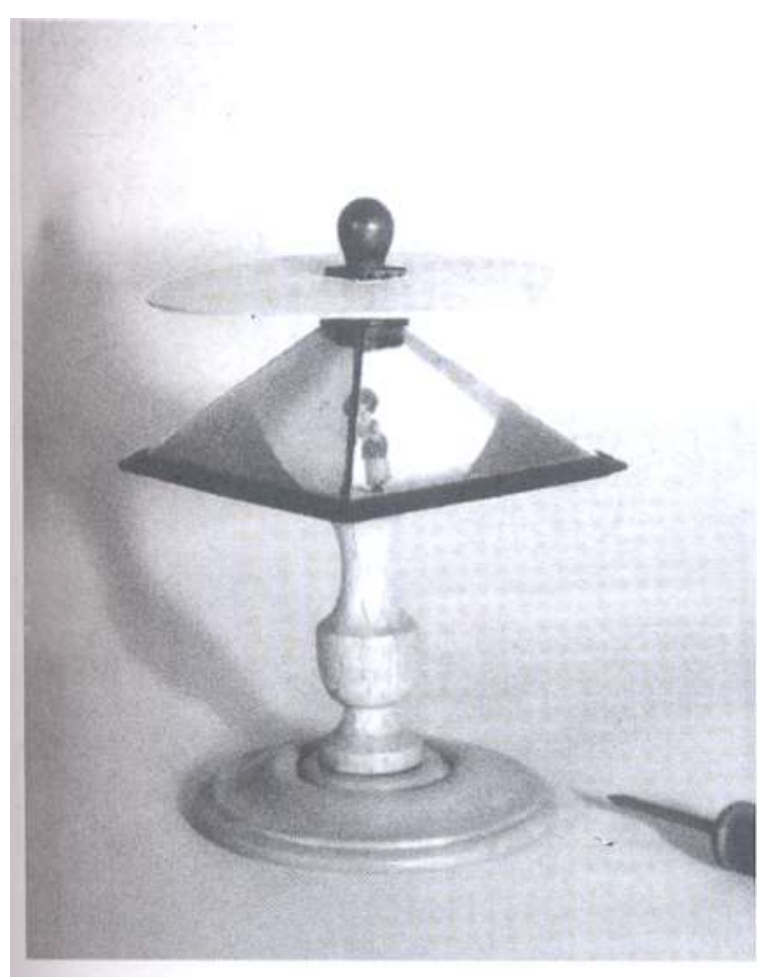

Figura 12: O pião-fantoche de Émile Reynauld, 1879. 


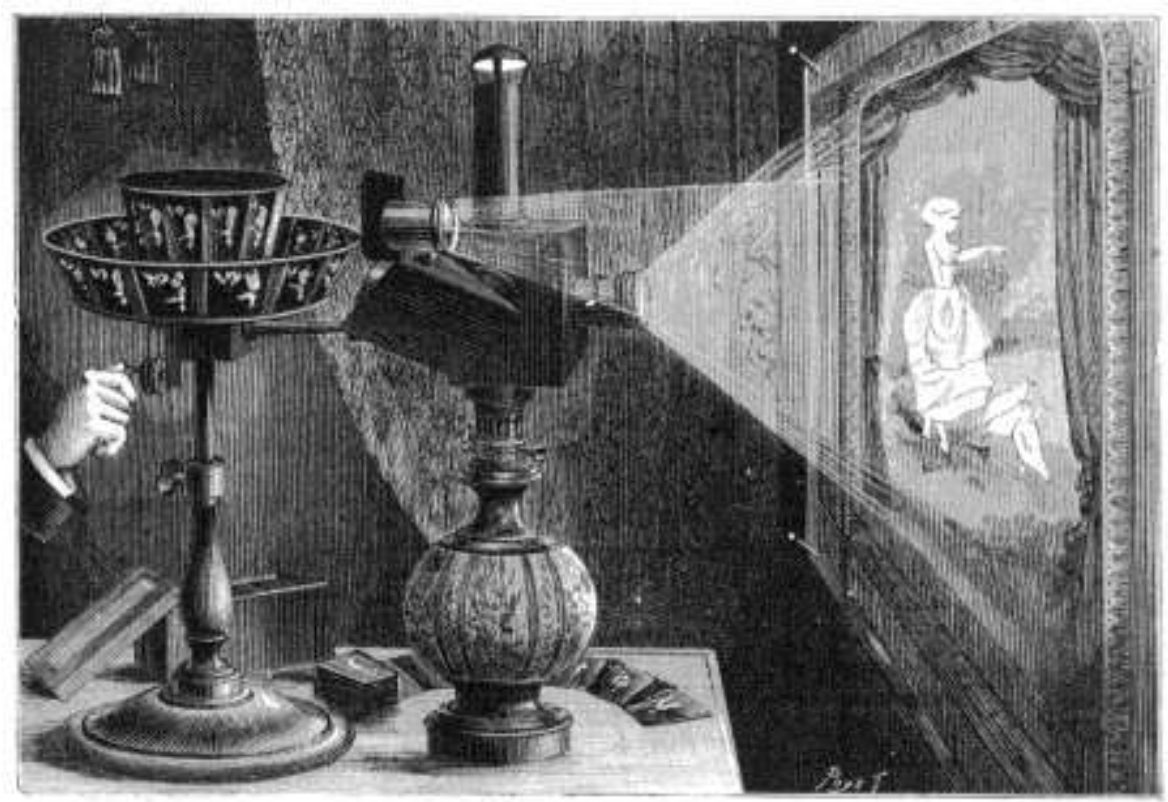

Figura 13: Praxinoscópio de projeção

Não tivemos a intenção de tratar de todos os aparelhos do pré-cinema, tentamos apenas dar ênfase nos aparelhos que eram apresentados, visualizados em telas diferentes da tela de sala de cinema de exibição (fixa, grande e frontal) e diversidade de modos de exibição das imagens em movimento. Tratamos como telas neste capítulo não apenas as que exibiam imagens projetadas por lanternas mágicas, mas também as telas que foram usadas como visualização das imagens em movimento em geral. Faremos um salto no tempo, deixando de lado muitos caminhos percorridos ainda nesse período do pré-cinema, isto é, deixaremos de lado dentre outros assuntos: todo o desenvolvimento da maior rapidez de processos fotográficos, o processo de obturação das câmeras, do uso do suporte de celuloide, do uso de furos no celuloide para que as imagens fossem projetadas com regularidade. Para saber mais sobre esses assuntos indicamos o livro de Laurent Mannoni: A Grande Arte da Luz e da Sombra. Passaremos a tratar brevemente da tela do cinema de sala de exibição, algumas modificações em seus formatos, para posteriormente falarmos dos cinemas experimentais e das modificações realizadas com as telas.

\subsection{Telas na sala de cinema.}

\section{Dimensões e formas das telas nas salas de cinema.}

$\mathrm{Na}$ sala de cinema padronizou-se o chamado dispositivo cinema, que segundo Machado foi detalhadamente descrito em dois textos de Jean- Louis Baudry : 
Cinéma: effets idéologiques produits par l'appareil de base (1970) e Le dispositif: approches métapsychologiques de l'impression de realité(1975). Conforme a descrição de Baudry, o dispositivo cinema compreende a sala escura que remete à caverna de Platão, o projetor ocultado às costas dos espectadores, as imagens projetadas numa tela branca à frente, as caixas de som também ocultadas etc [...] $\mathrm{O}$ modelo de cinema que hoje conhecemos começa a se consolidar na primeira metade do século 20 com o surgimento dos nickelodeons, as primeiras salas dedicadas exclusivamente à exibição de filmes, mas alcança o seu apogeu na década de 1910 com o surgimento dos confortáveis (e caros) palácios do cinema e dos feature films (filmes de longa-metragem).(MACHADO, 2012) ${ }^{21}$

Como apontado na citação acima, observamos no cinema uma padronização de apresentação de imagens em movimento em um local escuro, com arquitetura semelhante ao teatro italiano onde os espectadores permanecem sentados de uma a duas horas, observando as imagens projetadas que vêm de trás sobre uma tela geralmente branca, grande, única e de formato predominantemente horizontal. Este formato de tela do cinema de sala de exibição é mais limitado do que a os formatos de pintura, por exemplo. Segundo Bordweel e Thompson, as imagens na pintura ou fotografia "tem quadros de diferentes tamanhos e formas: retângulos estreitos, ovais, painéis verticais, e até triângulos e paralelogramos. No cinema a escolha é mais limitada.” (BORDWELL;THOMPSON, 2003. p.209, tradução nossa)

As medidas do tamanho do quadro no cinema e assim a proporção, formato com que as imagens aparecem na tela (e que contribuem para ditar o formato físico da tela) se devem à proporção da largura do quadro por sua altura e se chama proporção de aspecto (ou relação de aspecto). De acordo com Bordwel e Thompson (2003, p. 209), “ grosso modo, a dimensão da proporção se estabeleceu muito cedo na história do cinema por Edison, Dickson, Lumière e outros inventores. O enquadramento do filme tinha que ser retangular, suas proporções de aproximadamente de três para dois, gerando assim uma proporção de aspecto 1.33:1.”( BORDWEL ; THOMPSON, 2003, p. 209, grifo do autor, tradução nossa)

No período do cinema mudo alguns cineastas tentaram romper com as proporções padronizadas, gerais do cinema, inclusive da tela, como Sergei Eisenstein que, segundo Machado:

[...] se indispunha contra o dispositivo standard do cinema, inclusive contra o próprio formato retangular da tela, em posição horizontal, dita 'de paisagem', e contra as cadeiras confortáveis, que convidavam ao sono [..] No entender de Eisenstein, um cinema de agitação política, um cinema militante, como o que ele fazia, devia ser exibido nas praças públicas, numa tela vertical, para um público em pé e que pudesse reagir com indignação, fazer gestos políticos e entoar palavras de ordem durante a projeção.(MACHADO, 2012)

\footnotetext{
${ }^{21}$ MACHADO, Arlindo (2012). "Cinema e arte contemporânea". Revista Z Cultural- Publicações-Ano VII- 01. http://revistazcultural.pacc.ufrj.br/cinema-e-arte-contemporanea-de-arlindo-machado/ Acesso em dez. de 2013.
} 
Nesta dissertação, posteriormente retomaremos a este tema da disposição e alteração de tela e falaremos de outro cineasta, Abel Gance, que em seu filme Napoléon (1927) rompe com o dispositivo padronizado e o modifica, e, assim, aumenta o número de telas em sua obra.

Com a chegada do som aproximadamente no final dos anos 20 a proporção inicial, já comentada por Bordweel e Thompson, foi levemente modificada, devido à informação de que uma trilha sonora seria agregada à película, modificando o formato da imagem e diminuindoa horizontalmente, de modo a ficar com formato quase quadrado, com a proporção de aproximadamente 1.17:1.

Segundo Bordwell e Thompson, no início dos anos 30 houve uma padronização do formato para 1.33:1, embora muitas películas resultassem em 1.17:1. “[...] no início dos anos 30, a Academia de Artes e Ciências Cinematográficas de Hollywood estabeleceu a chamada proporção da Academia de 1.33:1. (Estritamente falando, na maioria das impressões isto resultava em 1.37:1; mas 1.33:1 continuava sendo considerava o padrão.)" (BORDWELL ; THOMPSON, 2003, p.209, tradução nossa)

A proporção fixada pela Academia foi mantida em vários locais do mundo até aproximadamente 1950. "Essa proporção era a repetição da janela das câmeras, assim como dos projetores." (DANCYGER, 2003, p. 114)

Nos anos 50, segundo Dancyger (2003,p. 113) outros formatos de proporção de tela cheia dominaram e trouxeram inovações em $35 \mathrm{~mm}$, com o Cinerama, CinemaScope, Vistavision e Panavision, e em 70mm com o TODD-AO, Technirama, Supertechnirama, MGM 65, e mais tarde IMAX.

\begin{abstract}
Os anos 50 trouxeram muitas mudanças para o cinema. $\mathrm{Na}$ área econômica, os decretos de 1947 (legislação antitruste que levou os estúdios a dispensarem os teatros que eles ganharam) e a crescente ameaça da televisão indicaram que a inovação ou, pelo menos, a novidade, poderia ajudar a recapturar o mercado do filme. (DANCYGER, 2003, p. 113)
\end{abstract}

Desta forma, algumas das inovações (que se diferenciavam da TV e assim poderiam atrair o público) seriam: o uso de filmes e telas largas e ainda, segundo Mattos, (2006 p. 122) a cor e a terceira dimensão. Nós iremos nos deter brevemente no formato das telas e dos filmes. Sobre a cor e terceira dimensão indicamos a leitura do livro de Antonio Carlos Gomes de Mattos Do cinetoscópio ao cinema digital: breve história do cinema americano.

Segundo Mattos, (2006, p. 127) um dos formatos usados para a tela larga foi o Cinerama (1952), era um processo de câmeras e projetores triplos, muito semelhante ao Polyvision usado por Abel Gance em Napoléon (1927). As imagens apresentadas eram três 
vezes mais largas e quase duas vezes mais altas que o padrão de $35 \mathrm{~mm}$.

As três câmeras trabalhavam ao mesmo tempo e registravam, cada uma delas, um terço da cena filmada; depois, três projetores projetavam os segmentos filmados sobre uma tela côncava, formada pela conjugação de três telas. A imagem projetada era três vezes mais larga do que a imagem padrão de $35 \mathrm{~mm}$, e também quase duas vezes mais alta, por causa de duas perfurações laterais extras (seis em vez de quatro) - a formatação (aspect ratio) variava de 3:1 a 2.6:1. (MATTOS, 2006, p. 127)

O som no Cinerama ,segundo o autor, era estereofônico (de 7 faixas) e, por isso, diferenciava-se do habitual envolvimento do espectador com os filmes apresentados em tela plana. Os espectadores pareciam estar cercados de imagem e de som. Era um processo dispendioso e muitos não o viam como apropriado para narrativas convencionais, não sendo também tão viável economicamente.

A invenção do CinemaScope é retomada em 1953 pela 20th Century Fox. Em Dancyger, (2003, p. 114) encontramos: "A invenção do CinemaScope aconteceu em 1929. Dr. Henri Chretien desenvolveu lentes anamórficas que, mais tarde, foram compradas pela 20th Century Fox. "Seu uso pela 20th Century Fox é introduzido em 1953, com o filme $O$ Manto Sagrado/The Robe (Dir.: Henry Koster). O processo utilizava lentes anamórficas durante a captação das imagens fazendo com que as imagens ficassem comprimidas e assim abarcassem um campo mais extenso do que os das objetivas normais.

[...] e na projeção, lente de propriedade inversa colocava as imagens filmadas em proporções normais, projetando-as em grandes telas retangulares. [...] $\mathrm{O}$ CinemaScope oferecia uma ratio radicalmente nova de 2.55:1, subseqüentemente reduzida para 2.35:1, e tinha a vantagem de não precisar de câmeras, filme e projetores especiais, apenas lentes especiais, uma tela larga metalizada e um som estereofônico magnético de quatro faixas. (MATTOS, 2006, p.130.).

A maior desvantagem desse sistema eram os problemas técnicos como a perda de brilho e a distorção de close-ups que foram diminuídos com o surgimento da câmera Panavision:

[...] a distorção de close-ups e planos de carrinho - foram superados com o desenvolvimento da câmera Panavision. [...] cuja projeção anamórfica oferecia uma imagem modificada em tela larga, com a proporção de 1:1.85 e em seu mais amplo uso anamórfico de $35 \mathrm{~mm}$ e $70 \mathrm{~mm}$, que permitia uma proporção de I:2.2." DANCYGER, 2003, p.122-123).

O Panavision era também um sistema anamórfico mas oferecia maior definição na imagem e menos distorção. Isto se deveu, pelo uso de lente prismática variável, inventada por Robert E. Gottschalk por volta de 1960. (MATTOS, 2006, p.130)

Com essa superação em relação ao CinemaScope os realizadores voltaram, segundo Dancyger (2003, 123), a usar os close-ups, o movimento da câmera e o ritmo foi recuperado. 
Outro processo de tela larga, de acordo com Dancyger, foi o Vista Vision (em 1954, e também é um sistema anamórfico) em reposta da Paramount Pictures ao CinemaScope. (único grande estúdio que não tinha licença para usar os filmes em Cinemascope). "Nesse processo, o filme de $35 \mathrm{~mm}$ corre horizontalmente em vez de verticalmente. O resultado é uma imagem mais nítida e uma maior flexibilidade sonora.” (DANCYGER, 2003, p. 115). Desta forma, conforme relata Mattos, produzia-se um negativo duas vezes mais largo que o convencional e também um pouco mais alto. "O negativo era então resolvido oticamente, $90^{\circ}$ no processo de copiagem, de modo que as cópias positivas pudessem correr verticalmente em qualquer projetor” (MATTOS, 2006,p 131).A Paramount, segundo Dacynger (2003, p.115), selecionou (indicava) 1:1.85 como proporção que tornou-se também um padrão de indústria. O VistaVision foi usado até aproximadamente 1961 quando a própria Paramount adota, informa Mattos (2006, p131), o Panavision por questões financeiras.

Nos anos iniciais da década de 1950 também foram utilizados os formatos de $70 \mathrm{~mm}$, 65mm, TODD-AO e Panavision 70. Estes tinham o formato maior (proporção de I:2.2) e assim mais espaço para o som (quatro trilhas de som magnéticas) e as imagens eram nítidas. O IMAX, que apareceu posteriormente, filma, segundo Dancyger (2003), como o VistaVision em 70mm, mas sua projeção corre horizontalmente (diferente do VistaVision que projeta verticalmente). Sua imagem é duas vezes mais larga que a produção padrão de $70 \mathrm{~mm}$. Uma tela padrão IMAX tem 22 metros (72 pés) de largura e 16,1 metros (52,8 pés) de altura, mas pode ser maior. $^{22}$

De todos os formatos o que mais se sobressaiu pela qualidade e por ser mais economicamente viável foi o Panavision, a partir de 1960, e superou os problemas (close-ups e planos em movimento) do Cinemascope e do VistaVision e assim a tela larga se tornou um padrão de indústria. (Embora este padrão tenha sido considerado de indústria, quase sempre os realizadores têm em mente o formato 1:133 já pensando em distribuir, transmitir os filmes pela TV.

Segundo Dancyger (2003, p.115), a proporção de I: 1.85 é padrão em muitos filmes. Algumas exceções são feitas para o formato I:2.2 quando se filma- em $35 \mathrm{~mm}$ anamórficos e amplia-se para 70mm, sendo assim projetados em telas ainda mais largas.

Mattos, (2006, p.132) informa que alguns filmes utilizavam cheiros (para aumentar o realismo) através de processos com sistemas de ar-condicionado para infiltrar aromas. $\mathrm{O}$

\footnotetext{
${ }^{22}$ Informação retirada da Wikipedia: http://pt.wikipedia.org/wiki/IMAX acesso em 10 de março de 2014)
} 
cheiro coincidia com cenas da tela. Esse processo era chamado de AromaRama (Charles Weiss) e foi usado no documentário La Muraglia Cinesa/1958 (Dir: Carlo Lizzani. Segundo Mattos(2006,p. 132- 133), o filme Scent of Mistery/ 1959 (Dir.: Jack Cardiff) trabalhava também com cheiros, mas esses eram emitidos para cada espectador por meio de pulverizadores colocados estrategicamente entre as fileiras de poltronas. Esse processo era chamado de Smell-O-Vision.

Os usos tecnológicos de que o cinema dispunha (cor, filme e tela largos, 3D, e cinema aromático) visavam atrair o público para as salas de cinema, assim disputando público com a TV. Essas mudanças, como o filme e telas largas, causam alterações nas questões de montagem. Segundo (DANCYGER, 2003, p. 116), tanto os diretores como os espectadores estavam habituados ao formato padrão de I: I.33 e agregavam a esse formato o uso de closeups, a alternância entre primeiro plano e fundo etc. "Com o advento do quadro, que é duas vezes mais largo, toda a relação, entre primeiro plano e fundo foi modificada.”(DANCYGER, 2003,p.116). As distâncias entre personagens devem ser repensadas para não ficarem muito distantes e desta forma não travar relações. "As implicações para a continuidade e o sentido dramático são claras. O quadro mais largo afeta o sentido.” (DANCYGER, 2003, p.117)

Essas alterações de formato, som, profundidade de imagem, cheiros têm o intuito segundo Dancyger (2003, p.113) de aumentar o espetáculo da experiência fílmica, mas ainda há a predominância da narrativa padrão.

Essas são algumas das possibilidades e experimentações em relação aos formatos e que tiveram maior predominância no cinema de sala. Experimentações nesses formatos foram realizadas por alguns diretores como, por exemplo, Griffith em Intolerance (1916), que consegue, pelo mascaramento, deixar visível apenas uma vertical bem fina (um retângulo estreito e vertical) para a imagem. Outros formatos (ovais, redondos, retângulos finos, altos, estreitos são possíveis pelo método de mascaramento. Muitos outros experimentos foram realizados principalmente no âmbito do cinema experimental, com o uso de múltiplas projeções, várias telas (que são o foco de nosso estudo) que serão vistas quando tratarmos do cinema de vanguarda, expandido e de exposição. Segundo Jeffrey Shaw,há duas correntes principais na artemídia. Em uma delas a experiência audiovisual tem bem limitada a fronteira entre a ficção (o espaço da tela) e o espaço real dos espectadores. Esta separação é dada pela "moldura de uma pintura, o arco do proscênio de um teatro, o envoltório de um aparelho de televisão ou a borda negra de uma tela de cinema, [...] estabelece uma janela mágica através da qual os espectadores contemplam espaços esteticamente planejados.” (SHAW, 2005, 
pp.356-357). A outra corrente quer se livrar desta separação entre tela, espaço da ficção e espaço do espectador. "Na história do cinema, a correspondência entre espaços narrativos emoldurados e sem molduras foi especialmente característico.” (SHAW, 2005, p. 357), Como vimos até aqui, a moldura do cinema de sala foi sendo estendida com o CinemaScope, o IMAX etc. Esse aumento no tamanho das molduras juntamente com experimentos como Sensorama, Smellorama "demonstram os anseios de imersão nativos do cinema." (SHAW, 2005, p. 357). Mas, mesmo com essas experiências, o cinema continua sendo emoldurado e com experiências afastadas, diferentemente das experiências realizadas pelo cinema expandido que desconstroem mais fortemente a moldura, transgridem a padronização da experiência visual e estabelecem a participação do público. Esses cinemas questionam dentre outros elementos padronizados do cinema clássico, os formatos usuais de apresentação das imagens e procuram em alguns casos, no lugar da nitidez, perfeição da imagem, a distorção, alterações visuais, atingindo estas outras qualidades pelo uso de várias telas (trabalhando-as espacialmente) e de materiais, formatos, posicionamentos diferenciados. Veremos alguns exemplos mais específicos quando tratarmos de cinema expandido, cinema de exposição.

Ainda nos cinemas de sala de exibição, os formatos de captação de imagens tanto padrão como os mais largos esboçados acima, são projetados em telas (físicas) que são confeccionadas (industrialmente) para que as imagens nelas projetadas tenham a melhor qualidade visual possível (nitidez, brilho, menor distorção, e em salas o maior ângulo de observação). Existe no mercado uma grande variedade de telas visando estas qualidades.

As qualidades referidas dependem de um conjunto de relações como: a distância da tela X, o tamanho do local onde as imagens serão apresentadas, sua distância em relação ao projetor, e principalmente sua relação de distância, altura e tamanho face à posição do espectador. Cálculos costumam ser realizados para posicionar a tela (altura dela, seu tamanho) em função do espectador, isto é, estudar a posição para que nenhum dos espectadores tenha prejuízo e dificuldade de leitura do texto (legenda) e que tenha uma qualidade visual das imagens e do som em qualquer lugar da sala de cinema, por exemplo.

Alguns tipos de tela:

Tela de superfície mate (sem brilho):

“A base da tela é recoberta com um material ligeiramente áspero, tinta branca de alto poder de reflexão ou com plástico misturado com pigmento branco em pó. Com isto a luz que vem do projetor é refletida com o mesmo brilho em todas as direções. [...] A vantagem deste tipo de tela: --Amplo ângulo de visibilidade com distribuição uniforme da luz.[...] Sendo a superfície macia, a imagem reproduz mais fielmente 
um slide sem grão e com todas as partes em foco.” ( BERNIER, s.d, p.38 )

Tela " perlado"

A superfície desta tela é coberta por pequenas esferas de vidro ou plástico. “ A luz que vem do projetor entra em cada esfera e é refletida internamente em um ângulo moderadamente aberto. Quanto maior a esfera, menor o ângulo de reflexão. [...] A imagem se torna mais granulada, especialmente para os que se acham perto da tela." (BERNIER, s.d ,p. 39)

Existem muitas superfícies trabalhadas para projeção 3D ou tradicional com materiais e camadas, tons etc., (aqui só nos detivemos em duas, apenas para dar alguns exemplos) que ao receber a projeção, influenciam o ângulo de visão, isto é, a nitidez e visibilidade uniformes para a área total da sala, por exemplo. As telas influenciam na nitidez, deixam ou não mais visíveis os grãos da superfície etc. As escolhas como, dito acima, são feitas de acordo com o tamanho do local, número de pessoas, iluminação etc. O que há em comum nas escolhas é a busca de qualidade visual e nitidez das imagens.

\subsection{Primeiro cinema}

Muitos autores estudam o cinema "inicial". Este estudo refere-se a um novo olhar sobre os filmes, formas que foram reobservadas por vários teóricos, dentre eles Charles Musser e Flávia Cesarino Costa. Esse olhar pretende ressaltar que os filmes do período de 1894 a 1908 principalmente, não foram apenas um caminho para o desenvolvimento do cinema narrativo, pois tinham diferenciações. Esta dissertação se baseou nos estudos de Flávia Cesarino Costa (2005), que explica o termo escolhido (primeiro cinema) para alguns filmes (do período 1894 a 1908, que são menos ligados à narrativa). São palavras dela:

\footnotetext{
Designaremos como primeiro cinema os filmes e práticas a eles correlatas surgidos no período que os historiadores costumam localizar, aproximadamente, entre $1894 \mathrm{e}$ 1908. Traduzimos como primeiro cinema a expressão inglesa early cinema. Sabemos que early cinema muitas vezes se refere às duas primeiras décadas do cinema, em que se destacam um primeiro período não narrativo (1894 a 1908),[...], e um segundo período (1908 a 1915) de crescente narratividade. (COSTA, 2005, p.34).
}

A autora se detém no estudo do primeiro período por ser menos ligado à narratividade. Ela prefere traduzir early cinema por primeiros filmes, pois não concorda com algumas denominações dadas, dentre outras como: cinema primitivo ou filmes primitivos, termo usado por Noel Burch. Para ela, estes termos relacionam a produção a uma visão determinista da história do cinema, que aponta tais filmes como pouco evoluídos "dentro de uma escala de 
aperfeiçoamento da linguagem do cinema." (Costa, 2005, p.34)

Nesse período estudado pela autora, principalmente, o movimento em si já bastava, era a principal atração e não haveria necessidade de narração como o cinema se mostrava após esse período. Não que não existisse uma narrativa, sim, existia, mas essa narrativa não tinha o forte efeito de diegese que posteriormente é estratificado.

Diegese é o processo pelo qual o trabalho da narração constrói um enredo que deslancha de forma aparentemente automática, como se fosse real, mas numa dimensão espaço- temporal que não inclui o espectador. O efeito diegético será mais intenso quanto menos evidentes forem as marcas de enunciação do discurso. (COSTA, 2005, p.32)

A partir do conceito apresentado por Costa sobre diegese, observa-se que os primeiros filmes quebram constantemente a diegese. Isso se revela através das descontinuidades, como quando os atores piscam, acenam para os espectadores, deixando claro que sabem de nossa presença.

Para nosso estudo, trataremos de ressaltar alguns usos de telas diferenciadas das telas de cinema de sala de exibição, para entendermos as variedades de modos que eram exibidos nas produções audiovisuais no chamado primeiro cinema. Enquanto ainda não havia cristalizado uma forma predominante de produção, apresentação (exibição), e, portanto as salas de cinema, as imagens projetadas eram realizadas em telas panorâmicas, utilizando vários projetores, arquitetura diferenciada, e a projeção é realizada à frente e atrás simultaneamente da tela dentre outras possibilidades, como o Kinetoscópio de Thomas Edison que, embora não trabalhasse com projeção, era mais um modelo diferenciado de apresentação de imagens em movimento. Aqui nos limitaremos, como dito acima, a ressaltar algumas possibilidades de dispositivos que utilizaram projeção ou que trabalharam a tela em formatos, tamanhos variados dos quais encontramos analogias e usos nas obras contemporâneas de apresentação de imagens em movimento.

Começaremos por abordar algumas atrações da Exposição Universal de Paris de 1900, que mostravam variados formatos de tela, e as apresentações nos vaudevilles onde também ocorriam formas diferenciadas de exibição.

A exposição de Paris de 1900 reunia a apresentação de muitas novidades, como automóveis, a atração da energia elétrica, e inúmeros aparatos, e dentre eles, imagens projetadas, imagens pintadas apresentadas em diferentes dispositivos. Segundo Costa, a exposição de Paris era "uma espécie de vitrine onde várias nações mostravam sua cultura e tecnologia." (COSTA, 2005, p. 24). Os industriais tinham ali a oportunidade de mostrar seus produtos e essas feiras eram, "o habitat cultural e social do tempo dos primeiros filmes 
(COSTA, 2005, p. 24). As formas de telas nessa exposição eram panorâmicas, circulares ou semicirculares, vários projetores disparavam imagens sobre estas telas. Simulavam-se sensações de andar de barco, de balão etc., nessas atrações. As formas de exibição eram totalmente diferentes das posteriores apresentações de cinema de sala. Segundo Costa (2005) as atrações visuais da feira se resumiam "a métodos de ilusionismo utilizando imagens, fotográficas ou não, para simular viagens no tempo e no espaço.”(COSTA, 2005, p.25). Dentre algumas atrações visuais com este objetivo, segundo a autora (2005, p. 25-26), se encontravam: panoramas estacionários e os animados (os quais comentamos anteriormente), o stereorama, em que a tela era móvel e efeitos de luz eram usados dando a impressão mais intensa de deslocamento dentro da paisagem. No mareorama, construído em um prédio de $40 \mathrm{~m}$ de altura, os espectadores viam uma paisagem pintada sobre uma tela de $15 \mathrm{~m}$ de altura que ia sendo desenrolada em seus mil metros lentamente e com efeitos de luz. Essa tela, inserida dentro de uma cabine de navio simulada, era movimentada por uma equipe escondida que simulava as oscilações marítimas. Havia ainda uma simulação olfativa de brisa marítima realizada pelo movimento de uma plataforma coberta de algas marinhas.

Ainda encontramos também nessa feira o Cineorama patenteado por Raul Grimoin Sanson em 1896. Nesse dispositivo as paredes brancas de um prédio circular de 360 graus servem de tela a esse dispositivo. Essa tela não era pintada e mostrava filmes de paisagens, “de um filme de $70 \mathrm{~mm}$ feito a partir de um vôo de balão real e colorido à mão." (Fielding ${ }^{23}$ apud COSTA, 2005, p.27)

Segundo Parente (2009, p 36), esse prédio tinha cem metros de circunferência e as imagens saíam de 10 projetores compondo uma única imagem. A projeção sincronizada trazia imagens de "vistas de decolagens e aterrissagens de balões, as últimas obtidas pela passagem do filme ao contrário". (PARENTE, 2009, p.36). O autor relata que o centro da sala apresentase uma cesta de balão com todos os elementos habituais desta e os projetores são inseridos nessas cestas. O teto era "coberto por uma cortina que imita um envelope de aeróstato." (PARENTE, 2009, p. 36)

Os irmãos Lumière usando o cinematógrafo projetaram filmes numa tela de $21 \mathrm{~m}$ de largura X 18 m de altura instalada no Champs-de-Mars,, um programa que durava 25 minutos, composto da projeção de 15 filmes e 15 fotografias em cores. (COSTA, 2005, p. 23).

Segundo a autora, os filmes que eram exibidos no contexto dessas feiras eram de paisagens externas como, por exemplo, gente tomando banho no rio. Mas desde 1895 já

${ }^{23}$ FIELDING, Raymond. "Hale's Tours: Ultrarealism in Pre-1910 Motion Picture”, in John L. FELL (ed.), Film Before Griffith, pp.116-130. Publicado antes em Journal of History,3, Smithsonian Institution, 1957. 
circulavam pela França outros tipos de filme, que apresentavam "números de magia, gags burlescas, encenações de canções populares e contos de fada. Estes filmes eram mostrados em quermesses, vaudevilles, lojas de departamento, museus de cera, circos e teatros populares." (COSTA, 2005, p.29)

Embora o cinema tenha se expandido para diversos locais, com diversos usos, segundo Toulet, ainda não era visto como uma atividade promissora. (COSTA, 2005, p.29),

Desses ambientes onde o cinema circulava nos interessam os café concerts e os vaudevilles, pois neles ocorriam diversas formas de apresentação das imagens em movimento. As telas podiam ser várias e essas apresentações eram misturadas. "Várias telas podiam ser estendidas ao longo desses ambientes para possibilitar projeções simultâneas, sincronizadas ou não com as músicas executadas ao vivo.” (MACHADO, 2008, p. 67)

As pessoas iam a esses ambientes para dançar, beber, comer e ver imagens.

A produção audiovisual do período da virada do século XIX para o XX é muito rica em formas de exibição, como atestaram as apresentações da Exposição Universal de Paris, e também pelas apresentações em outros espaços como os vaudevilles. Segundo Machado:

\begin{abstract}
Na virada do século XIX para o XX, não existia nenhuma forma padronizada de produzir e exibir filmes. O cinema de Thomas Edison, por exemplo, era exibido em visores individuais e não em uma sala escura coletiva como no modelo dos irmãos Lumière. Durante as primeiras décadas de existência do cinema, a projeção podia ser realizada em várias telas em vez de uma só, ou então vários projetores diferentes podiam ser apontados para a mesma tela, em front projection e back projection, de modo que possibilitasse efeitos de fusão, superposição, janelas simultâneas e inserção de uma imagem dentro de outra.(MACHADO, 2008, p.67)
\end{abstract}

Além disso, ainda segundo Machado (2008, p. 67), os filmes não vinham fechados; o exibidor poderia ainda modificar a forma, a sequência de exibição dos planos (que podiam ser comprados em rolos separados) do filme. Mostrando partes de filmes diferentes, "projetando por detrás da tela (back projection), em telas paralelas, ou fundindo duas ou mais imagens simultâneas na mesma tela (efeito de fusão decidido pelo projecionista e não pelo produtor).” (MACHADO, 2008, p.67)

\title{
2.6 Cinemas experimentais/ undergroung lavant garde.
}

Várias foram, segundo Renan, (1970, p. 3) as classificações, nomes dados a filmes pessoais feitos por uma ou poucas pessoas, realizados por expressão pessoal ou artística e que se afastam da maneira tradicional de produzir, montar, exibir filmes, diferindo também em 
relação ao conteúdo. Avant-garde, experimental, independente, subterrâneo ${ }^{24}$ são os mais usados. Renan (1970, p.2) salienta que a expressão "filme subterrâneo" pertence à década de 1960, mas afirma que os filmes pessoais e que diferem do filme tradicional já são muito mais antigos e receberam outros nomes.

Arlindo Machado também se questiona sobre estes termos e levanta a seguinte questão: O que é experimental? Em seu texto Pioneiros do vídeo e do cinema experimental na América Latina, o autor afirma que os filmes até por volta de 1960 eram classificados como “documentários “ ou como 'ficções”, mas haviam muitos obras audiovisuais que não se enquadravam em nenhuma dessas duas classificações e esses trabalhos foram chamadas de “experimentais". O autor exemplifica com a obra de Stan Brakhage que produz filmes colando asas de borboleta em película em branco. Sobre o termo "experimental", ele completa:

[...] "experimental" só pôde ser conceituado por sua exclusão, por aquilo que ele tem de atípico ou de não-padronizado, por aquilo, enfim, que não se define nem como documentário, nem como ficção, situando-se fora dos modelos, formatos e gêneros protocolares do audiovisual. O termo foi adotado com base no uso que já se fazia dele no cinema underground norte-americano a partir de finais dos anos 1950. Antes, principalmente nos anos 1920, utilizava-se o termo avant garde para designar propostas desse tipo. No campo do vídeo, o equivalente do cinema experimental era a vídeo-arte, que tinha horizontes e propostas estéticas semelhantes. [...] o conceito de experimental envolve mais coisas que a simples demarcação de uma diferença com relação à produção audiovisual estandardizada. Como sugere o próprio nome, a ênfase desse tipo de produção está na experiência, no sentido científico de descoberta de possibilidades novas. (MACHADO, 2010, p.25)

Ainda segundo o autor muitos outros nomes foram dados a este tipo de obras: como cinema de invenção usado por Jairo Ferreira, cinema expandido por Gene Youngblood "que seria uma espécie de cinema lato sensu, seguindo a etimologia da palavra (do grego kínemaématos + gráphein, "escrita do movimento"), que inclui todas as formas de expressão baseadas na imagem em movimento, preferencialmente sincronizadas a uma trilha sonora." (MACHADO, 2010, p.26)

Renan (1970, p.2) ressalta que a produção de obras "experimentais" aumentou muito por volta de 1960. Além de cineastas trabalhando no meio, o interesse era grande, entre artistas de outros meios e estudantes. Esse aumento deveu-se ao interesse no meio (pelo cinema na América), mas também ao barateamento do custo de filmes de $16 \mathrm{~mm}$ e $8 \mathrm{~mm}$ e pela facilidade de transporte dos equipamentos, mais leves (menores) e os filmes mais rápidos.

Renan (1970, p. 3) ressalta que esses filmes que foram classificados com vários rótulos como escrito acima, são às vezes divididos em três períodos conhecidos como três

\footnotetext{
${ }^{24} \mathrm{O}$ termo subterrâneo é equivalente ao termo underground. No Brasil o termo undeground também ficou ligado aos termos : udigrudi, cinema marginal.
} 
avant-gardes do cinema. $\mathrm{O}$ autor acrescenta ainda um quarto avant-garde que é chamado de cinema panorâmico.

O primeiro teria acontecido no período de 1920 e florescido da arte moderna, principalmente pelo dadaísmo e surrealismo. Assim como as obras de arte do período, foi chamado de avant-garde, que significava algo novo. Dessa época destacam-se: Entr'acte (1924) de René Clair que foi exibido no entreato no Ballets Suédois no Teatro de ChampsÉlysées em Paris, (a música do filme foi realizada por Erik Satie), Emak Bakia (1926) de Man Ray, e Un Chien Andalou (1929) de Luis Buñuel e Salvador Dalí.

O segundo período foi o de 1940. Ainda segundo Renan (1970, p.4) na época em que esses filmes foram concebidos foram chamados de filmes experimentais. Experimental também foi um termo usado para se referir a filmes de montagem dos russos em 1920. Em 1940 destacam-se alguns filmes em que a palavra experimental foi usada em relação a eles: Meshes of the Afternoon (1943) de Maya Deren, Fireworks (1947) de Kenneth Anger e The Lead Shoes (1949) de Sidney Peterson.

O termo experimental, segundo Renan (1970, p. 4) também fica associado a tentativa e erro ou por nunca ter sido feito antes. Muitos cineastas e artistas não aprovam o termo, pois não veem suas obras como experiências apenas, mas sim como "obras de arte consumadas". (RENAN, 1970. p 4), mas o termo experimental ,para o autor, fica ligado a filmes de 1940 e de hoje.

O terceiro período, foi da metade de 1950 até os dias de hoje. E os filmes que tinham então cunho pessoal eram chamados de: independentes e subterrâneos. (RENAN, 1970, p. 4)

Muitos teóricos e cineastas usaram subterrâneo, (underground) para falar desses filmes ou de seus próprios filmes, como o teórico Lewis Jacobs e o cinesta Stan VanDerBeek.

Este termo também não é aceito de bom grado por todos os cineastas, por suas conotações de clandestinidade, mas foi amplamente usado por críticos e por alguns cineastas.

O quarto avant-garde, que é mais amplo que os anteriores e chamado de cinema panorâmico e também de cinema expandido, (será mais bem visto no tópico 2,2.8).

Algumas características básicas desses filmes (três avant-garde) segundo Renan (1970, p. 5-17):

Os filmes de avant- garde da década de 1920 foram quase todos realizados em $35 \mathrm{~mm}$. Após a Segunda Guerra a bitola de $16 \mathrm{~mm}$, mais barata e mais fácil de trabalhar, foi disseminada e mais usada, embora muitos filmes também tenham sido feitos em $35 \mathrm{~mm}$ e no formato de $8 \mathrm{~mm}$. 
Os filmes têm duração variada, que vai de segundos a horas. A temática abordada é vasta, incluindo desde tomadas de família, sexo, protesto ou filmes abstratos cujo tema é sua forma, sua cor, sua luz. Como exemplo, temos o filme The Flicker (1965) de Tony Conrad, que tem apenas quadros pretos e brancos alterando-se de forma a poder provocar reações no espectador, como ilusão de cor, ilusão de uma luz que se espalha.

Existe uma forte indagação do que pode ser um filme nesses trabalhos. Andy Warhol, por exemplo, questiona isso, apresentando um filme em que o movimento quase não existe. Nam June Paik realiza Zen for Film, um filme sem qualquer imagem. Deste modo, "[...] a cada nôvo tipo de filme, a cada nova técnica, o filme subterrâneo amplia a definição de filme." (RENAN, 1970, p. 11)

Na montagem a narrativa não é seguida linearmente, ela é abrupta. São muitas as técnicas usadas e essas também podem ser vistas no cinema tradicional. Os cineastas/ artistas costumam modificar a captação das imagens adicionando lentes que não foram desenvolvidas para aquela finalidade. Como afirma Brakhage [...] "lentes que não foram nunca projetadas para uma câmera, ou mesmo lentes que o foram, mas podem ser empregadas contra as especificações, ou pode-se embrenhar na noite com um filme de uso indicado para a luz do dia e vice-versa [...].”(RENAN,1970, p. 15)

Os cineastas podem também filmar normalmente e posteriormente pintar, riscar a película, trabalhar com superposição, podem criar ainda mofos no filme, as formas criadas como faz Brakhage. A projeção também pode ser modificada pela adição de filtros, podendose ainda alterar a velocidade da projeção e usar muito mais técnicas.

Segundo Weibel (2003, p. 110) os filmes avant-garde no período do entre guerras tiveram na história do cinema uma posição marginal ou eram subprodutos dos movimentos das artes visuais, como: futurismo, cubismo, dadaísmo, surrealismo, etc. Vinculados a esses movimentos, esses filmes eram abstratos, animações pictóricas, filmes cinéticos, como os de Fernand Léger, Viking Eggeling, Hans Richter, László Moholy-Nagy, Oskar Fischinger, Man Ray, Marcel Duchamp, Len Lye, Lotte Reininger, Berthold Bartosch, Alexander Alexeieff e Claire Parker. Segundo o autor, esses filmes contribuíram para o desenvolvimento dos filmes chamados "experimentais" de "arte" no período após a Segunda Guerra. Weibel afirma que após os anos 60 a consciência mais efetiva deste meio como arte fez com que ocorressem mudanças em relação ao primeiro período (do entre guerras), quando ainda eram poucos os artistas que trabalhavam no meio, sem distribuição, sem teatros, sem organizações. No período de 60 , ao contrário, essa consciência fez com que artistas trabalhassem intensamente 
com o meio, não mais como subproduto da arte visual. Assim, desconstruíram totalmente o cinema clássico, como os artistas ligados a movimentos como Pop Art ou Fluxus.Andy Warhol e Yoko Ono são exemplos deles. Os artistas aumentaram suas organizações, revistas que divulgavam ou escreviam sobre os trabalhos, espaços de mostras e distribuição. Segundo Renan (1970, p.57) a partir de 1961 a divulgação do cinema subterrâneo cresce devido ao uso de filme de arte pessoal; muitos autores (principalmente cineastas) começam a escrever mais intensamente sobre esses trabalhos e a divulgá-los com mais frequência. "Essas pessoas incluíam Mekas, em Nova York, George Manupelli, em Ann Arbor, Bruce Bailie, em São Francisco, e John Fles, em Los Angeles. Todos, exceto Fles, eram cineastas.” (RENAN, 1970, p. 57)

\subsection{Uso e alterações nas telas em Napoléon (1927) Abel Gance.}

Começaremos com o emblemático Napoléon (1927) de Abel Gance que faz uso de telas diferenciadas do padrão de exibição de sala de cinema. Para Napoléon (1927) Gance empregou três telas no processo chamado "Polyvision".

Jean-Jacques Meusy (2000, p. 2) diferencia o uso de mais de uma tela de Gance em relação à ampliação de tela que acontece posteriormente nos anos 30 e 50 realizado pelo CinemaScope, PanaVision por exemplo. Para o autor, nessas ampliações de tela existia uma preocupação econômica (atrair o público para as salas de cinema, devido à ameaça da TV) diferente do posicionamento de Gance que era fortemente estético.

Ainda segundo Meusy, os filmes narrativos começam a abandonar o plano único comum no primeiro cinema e apresentam em uma tela retangular uma sequência linear de imagens de várias ações que ocorrem em espaços e tempos múltiplos, através da montagem paralela, alternada, flashbacks que para o autor são herdados dos livros (literatura) e assimilados rapidamente pelo público.

Para o autor, existiam alternativas a essa escrita fílmica, como várias imagens apresentadas na tela, seja por divisão, seja por sobreposições de imagens, A sobreimpressão segundo Meusy (2000, p.2) aparece desde os primeiros filmes e pode ser vista em Histoire d'un crime (Ferdinand Zecca, 1901), em que um personagem que está preso em sua cela sonha dias felizes mostrados na tela, através da sobreimpressão. Essas foram algumas das bases, segundo o autor, para o desenvolvimento da Polyvision. A tela dividida é usada para mostrar ações ocorrendo simultaneamente em espaços distantes, exemplo: personagens em uma chamada telefônica, onde se vê a pessoa falando e as expressões do interlocutor. A 
divisão de tela é usada, portanto, para mostrar cenas que pertencem a outro espaço-tempo.

Segundo Manovich (2001, p.IX) a montagem é uma tecnologia-chave para criar falsas realidades, e duas grandes técnicas (dentre outras possíveis) são muito usadas para isso. São elas: montagem temporal na qual se juntam planos sequencialmente, isto é, "realidades distintas formam consecutivos momentos no tempo". (MANOVICH, 2001, p.IX), ou a montagem espacial, técnica de apresentar realidades distintas coexistindo na mesma imagem, seja por sobreposição de imagens ou por várias telas. (muito usada pelos cineastas de vanguarda, como em $O$ homem com a câmera na mão de Vertov, que trabalha com sobreposição, e de Abel Gance em Napoléon que trabalha com três telas). A montagem espacial representa assim uma alternativa à montagem temporal tradicional.

Abel Gance usou amplamente as sobreposições de imagens como muitos outros cineastas do cinema mudo, mas ele queria ultrapassar essa embrionária montagem simultânea e assim estendeu as imagens para mais telas. Uma verdadeira "orquestração" de imagens em movimento. Segundo Meusy (2000, p.3), Gance usava cada tela como metáfora de um instrumento.

Abel Gance, segundo Meusy, quando explica ou trata da Polyvision, também o associa a polifonia mas a Polyvision não pode ser vista como ligada somente à polifonia musical e sim também à cinematografia em si.

A partir do texto de Gance Spoutnik du Cinéma: la Polyvision de 1957, Meusy observa e aponta as possíveis origens da Polyvison. Neste texto, há a comparação da Polyvision com a polifonia que para ele foi revolucionária na música no sentido de que foi modificando e ampliando as formas de ouvir. No século XIV, se havia um predomínio, na música,de apenas uma voz,isso foi ampliado. Tal processo poderia ser aplicado também às imagens apresentadas simultaneamente, vislumbrando-se novas possibilidades, um novo rumo ao cinema. Segundo Meusy (2000, p.3), Gance também deixa claro em seu texto sua reflexão cinematográfica, quando relata que pretendia mostrar muitas pessoas inseridas em algumas cenas em Napoléon, mas isso teria que ser apresentado em plano aberto e, portanto, as figuras seriam vistas pequenas, distantes e não expressariam o que ele pretendia. Ele teria os números, mas estariam tão afastados que não resultariam no efeito que ele pretendia, surgindo dai a ideia de estender as imagens para as laterais, a Polyvision.

Meusy aponta também mais algumas possíveis origens para a Polyvision e em uma delas está uma herança do retábulo do século XV. Nas artes visuais o retábulo foi usado intensamente na pintura da Idade Média. Eram construções de madeira, mármore, etc., que 
apresentam painéis pintados ou em baixo-relevo. Frequentemente tinham mais de um painel que eram ligados entre si, para compor imagens. Estes painéis eram ligadas por dobradiças (que possibilitavam abrir ou fechar a pintura). Eram apresentados nas igrejas, localizado por trás ou acima do altar. Desta forma a hipótese do autor de que os retábulos podem ter sido uma das influências da Polivision, aproxima-se de nossa hipótese (e assim contribui para justificá-la) de que os formatos de tela no cinema dos avant-garde e no cinema de exposição retomam procedimentos e formatos de visualização das imagens em artes visuais.

Meusy afirma (2000, p.4) que se Gance fala em tríptico, palavra muito usada por ele para se referir ao uso de três telas, antes de usar o termo Polyvision (o termo Polyvison é utilizado por Gance apenas após a Segunda Guerra antes disto se referia a essa apresentação em três telas como trípticos, trípticos panoramas), é diretamente uma alusão à pintura, aos retábulos do século $\mathrm{XV}$, principalmente, a quem devemos tantos formatos e termos como: dípticos, trípticos e polípticos. E ainda segundo o autor (2000, p.4), no tríptico da pintura, as telas laterais são dobráveis e possuem largura menor que a central. Desta forma a tela central pelo tamanho e pela posição (central, neste caso) acaba sendo priorizada.

Embora em Napoléon as telas sejam de mesmo tamanho, Gance continua, segundo Meusy (2000, p.4), essa tradição. Meusy exemplifica a relação entre as três telas de Gance e a prioridade da tela central, usando o tríptico Scènes de la Passion ,de Maître de Delft do século $\mathrm{XV}$.

Neste a cena clássica da crucificação é central. No painel esquerdo é apresentado um evento anterior à crucificação de Cristo é a apresentação deste por Pôncio Pilates para o público em um local diferente do da crucificação e o painel da direita apresenta a descida da cruz no mesmo local do painel central (a colina Gólgota), mas Meusy (2000, p.4) ressalta que o espaço e tempo desta obra é ainda mais complexo. Segundo ele, no painel central encontrase representado o doador da obra, isto é, um extemporâneo de Cristo, e no painel da esquerda a torre representada era "parte central da igreja nova em Delft, concluída em 1496, tanto anacrônico quanto distante geograficamente do morro do Gólgota.” (MEUSY, 2000, p. 4 tradução nossa)

Essas combinações heterogêneas de tempo e espaço eram comuns, segundo Meusy, na pintura religiosa. Em Gance isto também podia ser visto, segundo o autor (2000, p.5), nas sobreposições feitas em uma tela ou na apresentação das três telas. 


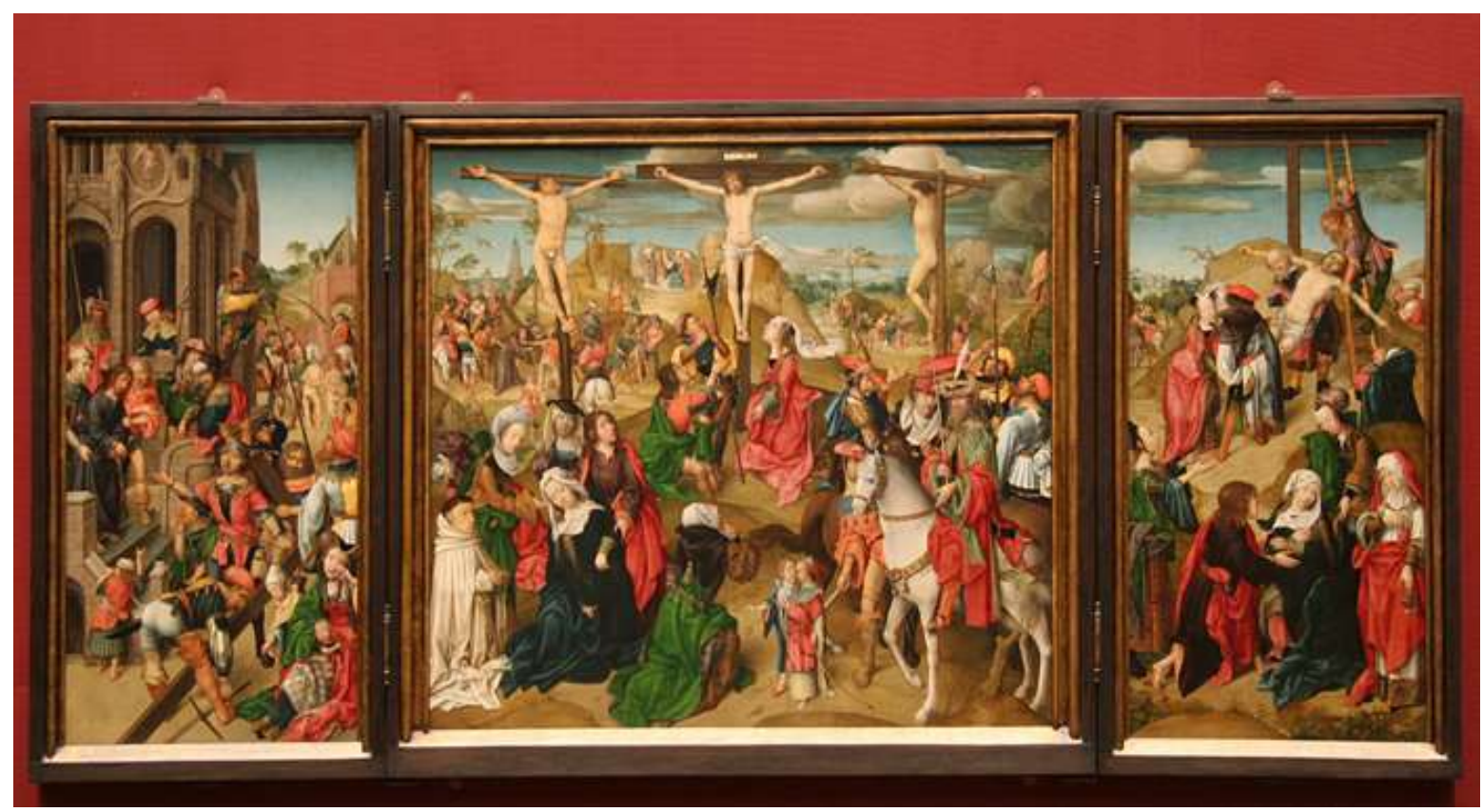

Figura 14: Maître de Delft. Scènes de la Passion. 1510.

Fonte: http://www.insecula.com/oeuvre/photo_ME0000097165.html

Em Napoléon a cortina se abria em algumas partes e as telas eram assim reveladas. Esta forma de apresentação, segundo Meusy (2000,p.19), também se assemelhava às pinturas tanto de trípticos, dípticos (que tinham de ser abertos) ou como tangka que eram recobertas por véus, por se tratar de pinturas valiosas e de admiração, não eram expostas o tempo todo. Tanto os dípticos, o trípticos e as tangka como também as telas de Gance, deveriam estar disponíveis sob determinadas circunstâncias.

.Gance escreve, em seus scripts para Napoléon, que duas cortinas cobrem as duas telas laterais e ao sinal de Bonaparte elas se abrem e a tela da lateral direita fica em vermelho e da esquerda em azul, "Vê-se o desenrolar de três ações que formam mais do que três telas combinadas em uma só, a tela branca mantém o centro das atenções.” (Gance apud Meusy, 2000, p. 9, tradução nossa)

A ideia principal apontada por Gance, neste texto, sobre as várias telas foi a busca da expansão do quadro, possibilitando ver mais coisas e numa escala bem maior do que seria possível na tela tradicional. (MEUSY, 2000, p.9)

As telas divididas são encontradas em algumas partes em Napoléon como na cena sobre a batalha dos travesseiros na escola de Brienne, quando a tela é dividida em quatro e nove imagens horizontais. Segundo Meusy, "o processo foi sugerido pela confusão desta batalha infantil" (MEUSY 2000, p. 10, tradução nossa), e também elas reaparecem no episódio da Batalha de Toulon, em que a tela novamente é dividida em três faixas verticais. 
A maior contribuição de Gance, ao cinema, segundo Meussy (2000, p.10), foi o uso de três telas. Mesmo que o filme tenha poucas partes em três telas e que poucas pessoas tenham visto efetivamente o filme nas três telas ( a grande maioria viu o filme em uma tela única). A tela tradicional tanto quanto a tripla, eram necessárias à obra e para os cenários.

Meusy (2000, p.11) destaca que a apresentação na ópera no dia 7 de abril de 1927 contava com uma tela de 15,3 metros de largura por 3, 85 metros de altura.

Abel Gance não foi o único a usar a Polyvison; outros cineastas o fizeram, como Philippe Arthuys, que realizou um longa metragem dessa maneira em seu Des Christs par milliers (1969).

O diálogo com as imagens múltiplas diferentes da forma tradicional de apresentação de imagem única, preenchendo toda a tela foi continuado por muitos. Tanto no uso de várias telas ou no uso de uma única tela dividida em multicamadas ou multijanelas, como, visto no trabalho de Henri Chomette, Chauffeur de Mademoiselle (1927) e seu irmão René Clair em les Deux Timides (1929). Após a Segunda Guerra, Inauguration of the Pleasure Dome (Kenneth Anger, 38 min, 1954), Thomas Crown Affair (Norman Jewison, 102 min, 1968), The Boston Strangler (Richard Fleischer, 116 min, 1968), The Pillow Book (Peter Greenaway, 120 min, 1996) etc. (MEUSY, 2000, p.25)

Finalizando, Meusy aponta que a tela grande teve diversos usos e indica que Gance a utiliza de forma diferente dos americanos. Os americanos usaram a tela grande após a Segunda Guerra, mas deixaram de lado alguns usos de Gance e de outros que usaram a Polyvision e o Hypergonar antes de ser o CinemaScope. Gance nunca quis uma única tela grande. Ele queria uma tela variável usando ora uma tela ora as três telas alternando assim o formato no decorrer do filme. Coisa deixada de lado com as imagens mais largas em cinemascope e demais tecnologias da imagem larga.

O autor aponta também que as tecnologias numéricas (digitais) facilitarão a apresentação e exibição de múltiplas imagens e de formatos variáveis. (MEUSY, 2000, p.26)

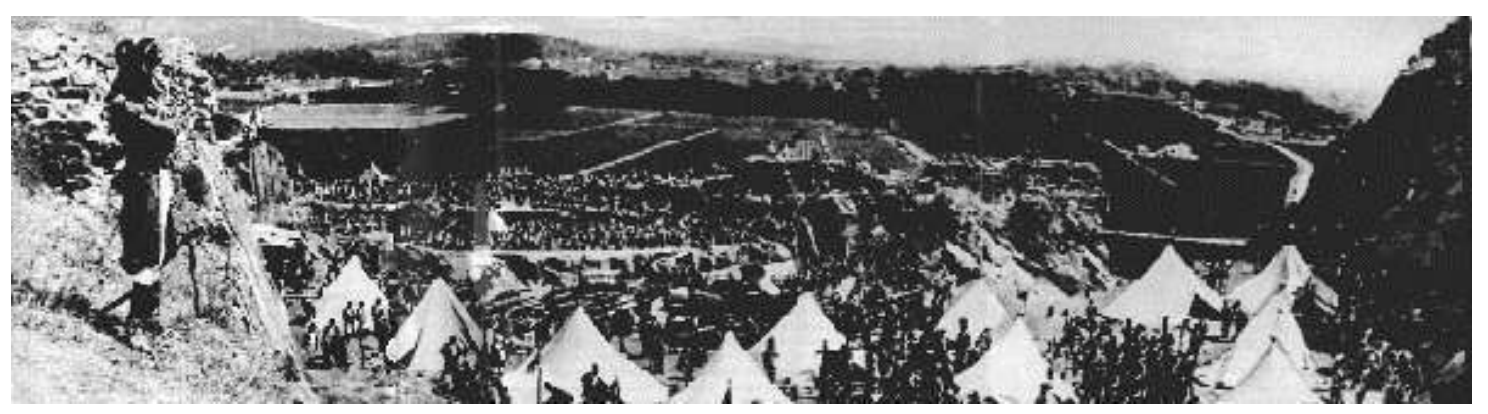

Figura 15: Abel Gance. Napoléon. 1927

Fonte: http://silentlondon.files.wordpress.com/2012/03/triptych.jpg 


\subsection{Cinema panorâmico/expandido}

Nos anos 60 a transformação do aparato do cinema foi muito maior e as telas foram expandidas mais intensamente. Comentaremos obras que trabalharam com diversas telas, ambientação, mas faremos antes um breve percurso sobre o que é chamado de cinema panorâmico ou cinema expandido.

O Cinema panorâmico surgiu por volta de 1960 e é o nome dado, segundo Renan, ao quarto avant-garde, que é mais amplo que os anteriores. Segundo o autor:

Cinema panorâmico não é o nome de um estilo especial de cinematografia. É um nome para um espírito de pesquisa que está levando a muitas direções diferentes. É cinema panorâmico incluir muitos projetores diferentes na exibição de uma obra. É cinema panorâmico incluir imagens geradas em computador e a manipulação eletrônica de imagens de televisão. É cinema panorâmico o ponto em que o efeito de filme pode ser provocado sem que se empregue filme algum. (RENAN, 1970, p. 133)

Ainda segundo o autor (1970, p.133), esse cinema panorâmico difere em alguns aspectos do cinema subterrâneo, (experimental/ avant-garde) que comentamos acima. Nele incluem-se, como já afirmado, muitos projetores para uma única obra, imagens geradas por computador e também imagens manipuladas de televisão, "Sua obra é mais espetacular, mais tecnológica e mais diversa em forma do que o filme avant-garde/experimental/subterrâneo [...] (RENAN, 1970 p. 133). Ele é considerado como um quarto avant-garde por ser uma continuação da pesquisa de cineastas participantes dos outros avant-garde, mas o filme avantgarde é apenas uma das fontes do cinema panorâmico, pois este se liga a preocupações com outros meios. "Os artistas querem trabalhar sôbre muitos meios e combinar os muitos meios em uma obra." (RENAN, 1970, p.134)

Os fatores de mudança do cinema para cinema panorâmico segundo o autor (1970, p.134) foram; o desenvolvimento de novas sensibilidades disseminadas por todas as artes, o surgimento de novos materiais para arte como: televisão, videotape, computadores etc. As obras em geral não se limitam mais a elas apenas, mas englobam um ambiente, o espectador.

Outra diferenciação segundo o autor (1970, p.133-134) entre o cinema panorâmico e os cinemas experimentais/avant-garde é que o primeiro não segue a ordem de produção/exibição do segundo, ou seja, concepção, direção fotografia, edição numa forma mais ou menos permanente para posterior projeção em uma tela. No cinema panorâmico os artistas/cineastas querem romper com a ideia do cinema como algo fechado, terminado, que pode ser apresentado em dadas máquinas específicas e sob condições prévias. Neste cinema há uma intensificação da quebra de padronização nos modos de apresentação das imagens em movimento. "Emprega-se outros materiais, além do filme para produzir o efeito aproximado 
do filme. Há a televisão, é claro. Há instrumentos de côr e projetores overhead. E há peças de sombras.”(RENAN 1970, p.143)

Segundo Renan (1970, p.59) este cinema que se expande volta-se para técnicas préfílmicas quando inclui espetáculos de luzes e de sombra, retroagindo assim a técnicas de peças de sombras da Ásia, ao jogo que fazia o homem pré-histórico com sua sombra.

Por volta de 1960, a pesquisa artística utilizando imagens em movimento se intensifica, vindo a dar no chamado cinema panorâmico, termo usado por Sheldon Renan, e cinema expandido, termo usado primeiramente por Stan Vanderbeek e posteriormente tratado e estudado por Gene Youngblood. O cinema se expande, e novas formas e usos da imagem em movimento se intensificame, para Youngblood, expandem juntamente com a consciência; o cinema tradicional não dava mais conta da consciência do homem da época. A TV enfatiza isso, estando mais próxima da consciência do homem da época pelo seu procedimento de mostrar pessoas, eventos, enfim, a condição humana com a qual segundo ele (1970, p. 78) nos identificamos. Essa identificação no cinema tradicional era feita com atores em uma ficção. $\mathrm{O}$ autor aponta que as mudanças no cinema se devem também à TV., que, segundo ele (1970, p.78), produziu mudanças no cinema assim como a foto fez com a pintura. "As artes plásticas abandonaram a realidade exterior para a realidade interior." (YOUNGBLOOD, 1970, p.78, tradução nossa). Assim, no cinema, os filmes não são mais realistas e voltam-se para o interior, enfatizando uma mudança, uma atualização, que podem ser vistas no cinema que ele chama de sinestésico, isto é, um cinema em que "o homem tenta interpretar um o fenômeno total de sua consciência" (YOUNGBLOOD, 1970, p.77, tradução nossa). Este cinema sinestésico consegue ser como a mente do homem da época, que ele chama de paleocibernética, época denominada por muitos autores de pós-industrial. Esse cinema não é linear, uniforme e por isso se aproxima da consciência do homem e também a faz expandir. Algumas características do cinema sinestésico: o todo aparece junto, a impressão é geral, diferente do cinema tradicional, em que o cineasta guia nossos olhos para uma imagem, depois outra; que preenche frequentemente toda a tela. Existe ainda no cinema sinestésico (1970, p.86) o continuum espaço e tempo embora a montagem evite o elemento estrutural inerente ao meio; a montagem neste cinema é dissolvida em sobreposições, superposição, não para narrar, mas sim estabelecer metamorfoses.

Segundo Santaella (2008, p.162) a expressão cinema expandido se refere a várias formas de trabalhos que tinham em comum a crítica aos mecanismos padronizados dos equipamentos cinematográficos e segundo a autora essa crítica pode ser resumida a : 
“multiplicação dos níveis de projeção, abolição das fronteiras entre diferentes formas de arte, retorno à corporalidade, desconstrução das técnicas fílmicas e a criação de obras de arte feitas de pura luz." (SANTAELLA, 2008, p. 162)

Segundo Weibel, durante a década de 1960 o código cinematográfico foi sacudido, os artistas realizaram experimentos com materiais do cinema como a película:

\footnotetext{
[...] em vez de exporem o celuloide, arranharam-no (George Landow, Film in Which There Appear Sprocket Holes, Edge Lettering, Dirt Particles, etc., 1965-1966; Wilhelm \& Birgit Hein, Rohfilm, 1968), perfuraram-no com um furador (Dieter Roth, 1965), pintaram-no (Harry Smith usou material de filme $35 \mathrm{~mm}$, processandoo com graxa, tinta, fita adesiva e spray, 1947), cobriram-no com digitais (Peter Weibel, Fingerprint, 1967) ou colaram mariposas a ele (Stan Brakhage, Mothlight, 1963, no qual asas de mariposas e folhas foram fixadas entre camadas de fita perfuradas e projetadas). Molduras vazias, filme preto e material superexposto também foram usados. (WEIBEL, 2005, p. 333)
}

Ainda segundo o autor por volta de 1960 todos os elementos do cinema foram experimentados; desde a câmera até o projetor foram usados de maneiras diferentes do padrão. A película, por exemplo, foi usada sem processamento como em Zen for film de Nam June Paik, as telas foram multiplicadas e nessa multiplicação a narrativa tradicional temporal associada ao cinema de sala foi ampliada, multiplicada, surgindo assim outras formas de narração que para Weibel estavam mais afinadas com a percepção do mundo.

\footnotetext{
$\mathrm{Na}$ era das revoltas sociais, drogas de expansão da consciência e visões cósmicas, os ambientes de projeções múltiplas tornaram-se um importante fator na busca por uma nova tecnologia de produção de imagens capaz de articular uma nova percepção do mundo. (WEIBEL, 2005, p. 336)
}

As telas nesses trabalhos eram como uma forma de visualização em que a intenção era possibilitar outras maneiras para narrar e também obter novas experiências visuais. O grupo USCO (abreviação de US Company) trabalhou intensamente com shows de multiprojeção. Seu Hubbub, por exemplo, "é uma mistura-de-meios multicanal de filmes, fitas, osciloscópios, estroboscópios, imagens cinéticas e vivas.” (RENAN, 1970. p.137). Muitos outros experimentos foram realizados destacando as multiprojeções, multitelas e ambientação, como no gigantesco evento que ocorreu na Expo 1967 em Montreal. Deste evento citaremos algumas obras que fizeram o uso de diferentes telas e também obras que fizeram tal uso em outros contextos.

Essas obras retomam procedimentos vistos por nós no pré-cinema, quando comentamos sobre a fantasmagoria que envolve outros sentidos que não só a audição e a visão. A fantasmagoria trabalhava com vários sentidos além da audição e visão, que é um dos intuitos do cinema expandido. Assim também foram trabalhados os panoramas, dioramas, 
para além dos dois sentidos (visão, audição) mais associados ao cinema tradicional. Na fantasmagoria usavam-se locais escuros, com decoração, som, algumas vezes descarga elétrica nos corpos, e fumaça para apresentação de imagens, e não raro alguma ação ao vivo, misturando-se ao que aparecia na fumaça, (como visto no tópico 2.2) e, produzindo toda uma ambientação. No cinema expandido vemos que as telas se ampliam em número, tamanho, associam-se a filmes com performers ao vivo, contrapondo-se com imagens gravadas ou ao vivo, ambientes sensoriais com fumaça, com cheiros, com luzes, projeções múltiplas etc.

Stan VanDer-Beek, em seu projeto Movie-Drome, constrói um cinema hemisférico no quintal de sua casa em Stony Point, Nova York. Um cinema para receber projeções múltiplas. A tela neste cinema era curva e contínua.

Segundo Sutton (2003, p.136) em Movie Drome não havia entrada formal e os espectadores entravam na cúpula por baixo. Dentro da cúpula as pessoas podiam ficar deitadas, os locais, estavam apenas esboçados. Segundo Sutton (2003, p. 136), a experiência desta obra é diferente, pois não se sabe ao certo o que se esperar. São ruídos de projetores de $16 \mathrm{~mm}$ (slides) misturados a sons distorcidos de vozes de fontes indeterminadas como som de músicas pré-gravadas, discursos políticos e noticiários. As projeções eram colagens de imagens de noticiários, filmes encontrados. Os projetores giravam pois encontravam-se sobre bases giratórias. O som reverberava pelo alumínio curvo. O local caracterizava-se pelo calor interior, produzido tanto pelos aparelhos como por todas as pessoas ali, mais ou menos 30 . As imagens projetadas estavam em contato com o que circulava na época tanto por meios de comunicação como pela arte. O que mais trazia estranhamento aos participantes eram a justaposição de imagens apresentadas ilogicamente, a velocidade em que eram exibidas e as técnicas de trabalho, diferentes da experiência cinematográfica ou de multimídia da época. A autora afirma (2003, p.136) que mesmo o público acostumado a ver e ter experiências com a arte tanto pelo filme underground, como pelas performances art e happenings, e até ao público adaptado às telas largas do cinema comercial, estranharam tal experiência, que tinha como principal eixo a experiência fenomenológica de múltiplas imagens projetadas (que era o assunto do trabalho). As imagens eram satíricas, misturavam-se ou transformavam-se. A estátua da Liberdade, por exemplo, apresentava-se como misseis nucleares renderizados. Com este trabalho fica constatado que a visão não se limitava apenas ao confinamento do quadro retangular da pintura e nem à janela alongada do cinema.

Este domo segundo a autora (2003, p. 137) essa cúpula esférica e essas projeções diferenciavam dos padrões de visualização padrão de cinema ou de contemplação solitária em 
museus.

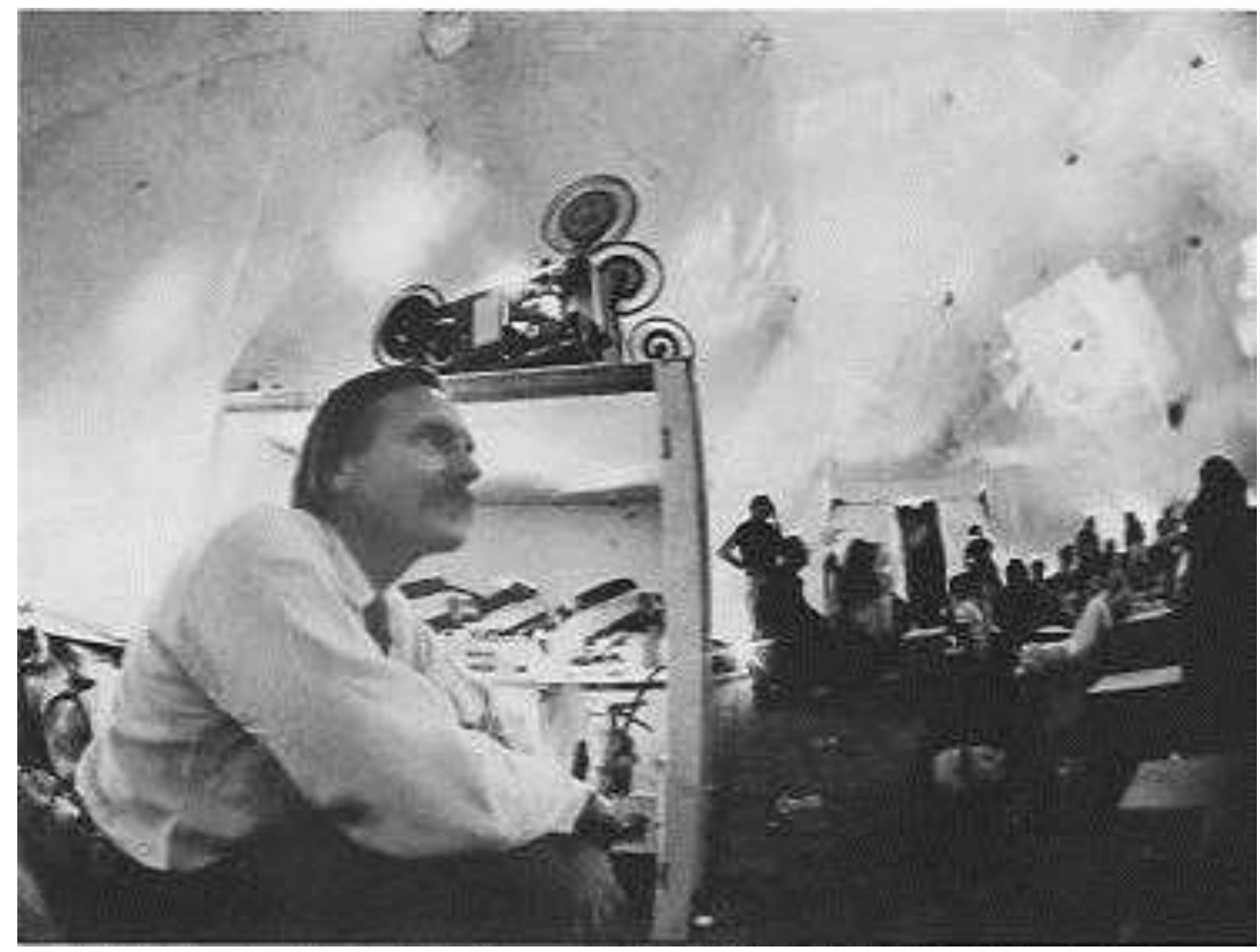

Figura 16: Stan VanDerBeek. Movie Drome.1963

Fonte: Youngblood, Gene. Expanded cinema.1970, p.350. Foto: Bob Hanson.

Segundo Le Grice (1977, p.143), o evento da projeção permaneceu secundário durante muito tempo, mas recentemente principalmente após 1960, ela torna-se o evento em si, de tal modo que em algumas obras, o próprio filme (película) foi deixado de lado e substituído pelos elementos físicos que estavam presentes na situação da projeção, o que deixava o ato de filmagem em segundo plano. Muitas vezes os elementos que substituem a película são corpos e, portanto, as obras se ligam e hibridizam a arte corporal. Não raro o projetor se transforma em câmera através da focagem em zoom e dos seus movimentos. Existem ainda obras que são ligadas mais especificamente à própria projeção, como os trabalhos de Antony MacCall, dentre eles, Line describing a cone, de 1973, no qual o artista não projeta imagens no sentido tradicional. A projeção, o próprio cone de luz, a duração, a relação com o espaço e os espectadores é o que importa. Nesta obra o artista apresenta um projetor instalado em uma sala escura que projeta luz e no decorrer do tempo vai formando um círculo. Nessa sala ocorre 
a produção de fumaça por máquinas, assim, a luz do projetor adquire volume e o cone de projeção é o que mais chama atenção na obra. Nesse trabalho os espectadores andam e entram no cone de luz.

Um exemplo que envolve performance e os dispositivos mais associados ao cinema como projeção e tela é a obra Horror film I (1971) de Malcolm Le Grice. Nela o artista se aproxima e se afasta da tela a sua frente enquanto três projetores lançam projeções de cores que incidem no corpo dele e projetam sombras deste corpo de vários tamanhos (devido à movimentação do artista) na frente da tela.

A Expo 1967, foi um evento que ocorreu em Montreal e foi, segundo Marchessault ${ }^{25}$ (2007) realizado para celebrar o centenário do Canadá ${ }^{26}$. Este evento foi, segundo o autor, semelhante a outras exposições mundiais, ou seja, são locais para onde se levam e se estimulam as futuras tecnologias. No entanto, diferiu dos demais pelo excesso de mostras de tecnologias audiovisuais: mais de três mil filmes foram produzidos para ele e muitos festivais de filmes se conectaram ao evento como, por exemplo, o Montreal Film Festival. Sessenta e cinco por cento do que foi mostrado neste evento nos pavilhões eram imagens em movimento que foram apresentadas na grande maioria como "nova flexibilidade das telas e nova sinestesia da cultura visual do mundo mediada pela tecnologia”. (MARCHESSAULT, 2007, tradução da autora). Como dito, muitas obras foram apresentadas na Expo 67 por múltiplas projeções, diversas telas e um dos artistas que lá também mostrou sua obra Francis Thompson, que trabalha com imagens múltiplas e que se interessava tanto por projeções de imagens gigantescas como pequenas afirma sobre o cinema expandido:

No que diz respeito à ideia de cinema expandido, eu gostaria de fazer um teatro que
seria uma esfera enorme, tão grande como Radio City Music Hall ou maior, e assen-
tar o público em torno de um dos lados: uma série de varandas para todo mundo na
fila. A plateia se tornaria parte da esfera. A imagem vem de todos os lados, ao redor
tanto quanto se pode ver, e abaixo de você também. "O que eu gostaria de ver é um
teatro com uma área tão grande que você não pensaria mais em termos de uma tela:
é a área que você está projetando. Suas imagens devem sair desta grande, área com-
pletamente envolvente e bater em você. nos olhos ou sair para o infinito. Então você

${ }^{25}$ MARCHESSAULT, Janine. "Multi- Screens and Future Cinema: The Labyrinth Project at Expo 67, in: MARCHESSAULT, Janine; LORD, Susan (edits). Fluid Screens, Expanded Cinema. Toronto, ON: University of Toronto Press, 2007, 29-51. Disponível em: http://books.google.com.br/books?id=W5vpaSh5PwIC\&printsec=frontcover\&dq=Fluid+Screens,+Expanded + Cinema\&hl=en\&sa=X\&ei=VJGgU6CSH8_JsQTe0oL4Cg\&redir_esc=y\#v=onepage\&q\&f=false .Acesso em abril de 2014.

${ }^{26} 100^{\circ}$ aniversário da Confederação Canadense : foi o processo pelo qual o Federal Dominion de Canadá foi constituída em 01 de julho de 1867 Nesse dia, três. colônias britânicas se tornava em quatro províncias do novo domínio. O existente Estados Província do Canadá foi dividido nas novas províncias de Ontário e Quebec, e outras duas colônias, New Brunswick e Nova Escócia, tornou-se também as províncias do novo Domínio do Canadá, retirado da wikipedia em 8 de abril de 2014), 
não está trabalhando com uma superfície plana, mas sim um volume infinito." (THOMPSON apud YOUNGBLOOD, 1970, p.354 -358, tradução da autora) ${ }^{27}$

Thompson apresenta na Expo 67 no Pacific-Cominco Pavilhão a obra We are Young na qual usou seis telas que cobriam segundo Youngblood (1970, p.355) uma área total de 274,25 metros quadrados, diferentemente da sala de cinema comercial, que possui em média 41,806 metros quadrados. Stanton ${ }^{28}(1997)$ relata que o tema da obra versou sobre jovens que enfrentam a vida. Foi, segundo Stanton, a maneira de exibição da obra que a tornou importante.

Na Expo 67 o número de telas nas obras variava de 2, 3, 9 chegando a apresentação a ter 112 cubos de telas em movimento, o que foi exibido segundo Weibel (2005, pp.336-337) no pavilhão checo, onde podiam ai ser exibidos 160 slides simultaneamente (tela Diapolyceran).

Ainda na Expo 67 foi apresentada a obra Labyrinthe (1967), projetada por Colin Low e Roman Kroitor e organizada pela NFB (National Film Board do Canadá). Segundo Marchessault (2007) esta obra juntamente com as outras apresentadas ilustra o desejo dos artistas de criar novas arquiteturas para a imersão sensorial e para expandir a experiência do filme.

Segundo Stanton (1997) a obra tem como intenção ilustrar a ideia de labirinto que, na antiguidade, tinha como mito um herói que entra no labirinto e tenta matar o Minotauro (devorador de homens). Para fazer o mito contemporâneo, os cineastas "developed a new kind of walk-through cinema and they shot film throughout the world." Stanton (1997). Eles tentaram mostrar o labirinto em que o homem moderno se encontra, tentando enfrentar a si mesmos, em lugar do Minotauro. O herói neste trabalho era representado pelos espectadores, que entravam em um labirinto e eram conduzidos, segundo Stanton (1997) na escuridão por rampas ate chegarem a varandas de forma elíptica, das quais, podiam ver um filme em uma tela vertical gigantesca de aproximadamente $15,24 \mathrm{~m}$ de altura e uma outra tela no chão. Quando as cenas dessas telas desvaneciam, os espectadores eram levados a uma segunda sala

\footnotetext{
${ }^{27}$ As regards the idea of expanded cinema, I would like to make a theatre that would be a huge sphere, as big as Radio City Music Hall or larger, and seat the audience around one side of it: a series of balconies so everybody's in the front row. The audience would become part of the sphere. The picture comes around as far as you can see, and beneath you too. "What I would like to see is a theatre with so great an area that you no longer think in terms of a screen: it's the area you're projecting on. Your images should come out of this great, completely surrounding area and hit you in the eye or go off into infinity. So you're no longer working with a flat surface but rather an infinite volume. (THOMPSON apud YOUNGBLOOD, 1970, p.354 -358)

${ }^{28}$ STANTON, Jeffrey. Cinema Experimental Multi- Screen. Disponível em: http://www.westland.net/expo67/map-docs/cinema.htm, acessado em 09 de junho de 2014
} 
com um escuro labirinto de espelhos, sinuosos corredores, luzes piscantes e sons que levavam, por sua vez, a outra sala, que mostrava diferentes cenários em cinco telas dispostas em cruz.

Segundo Marchessault (2007) Labyrinth "pode ser lido como o campo de treinamento sensorial para o novo cidadão global, onde as entradas de informação simultâneas não criam confusão que entorpece os sentidos, mas uma nova 'consciência oceânica'." MARCHESSAULT, 2007, tradução nossa)

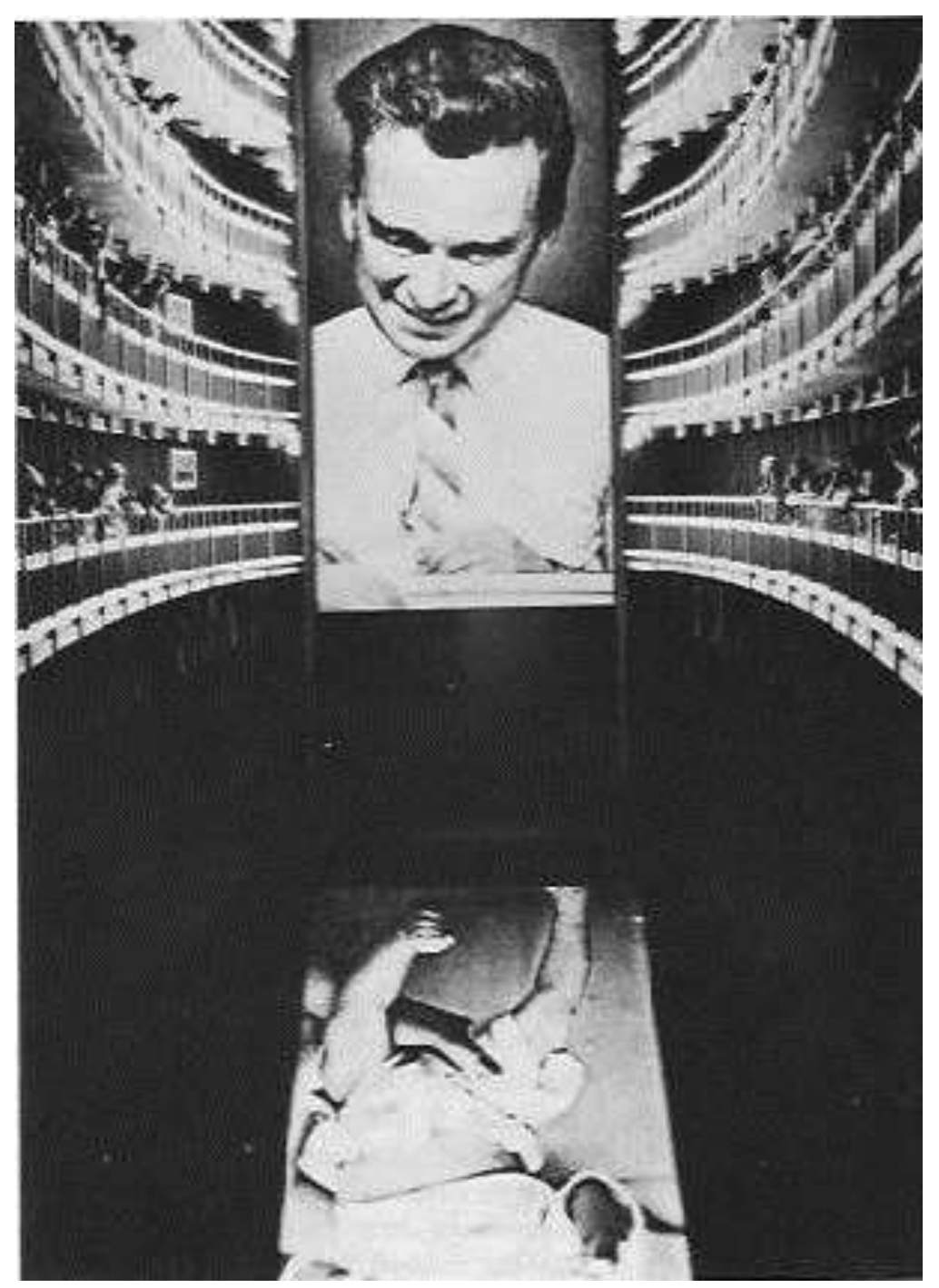

Figura 17: Roman Kroitor's Labyrinthe 1967

Sala um da obra Labirinto com duas telas

Fonte: Youngblood, Gene. Expanded cinema.1970, p.353 


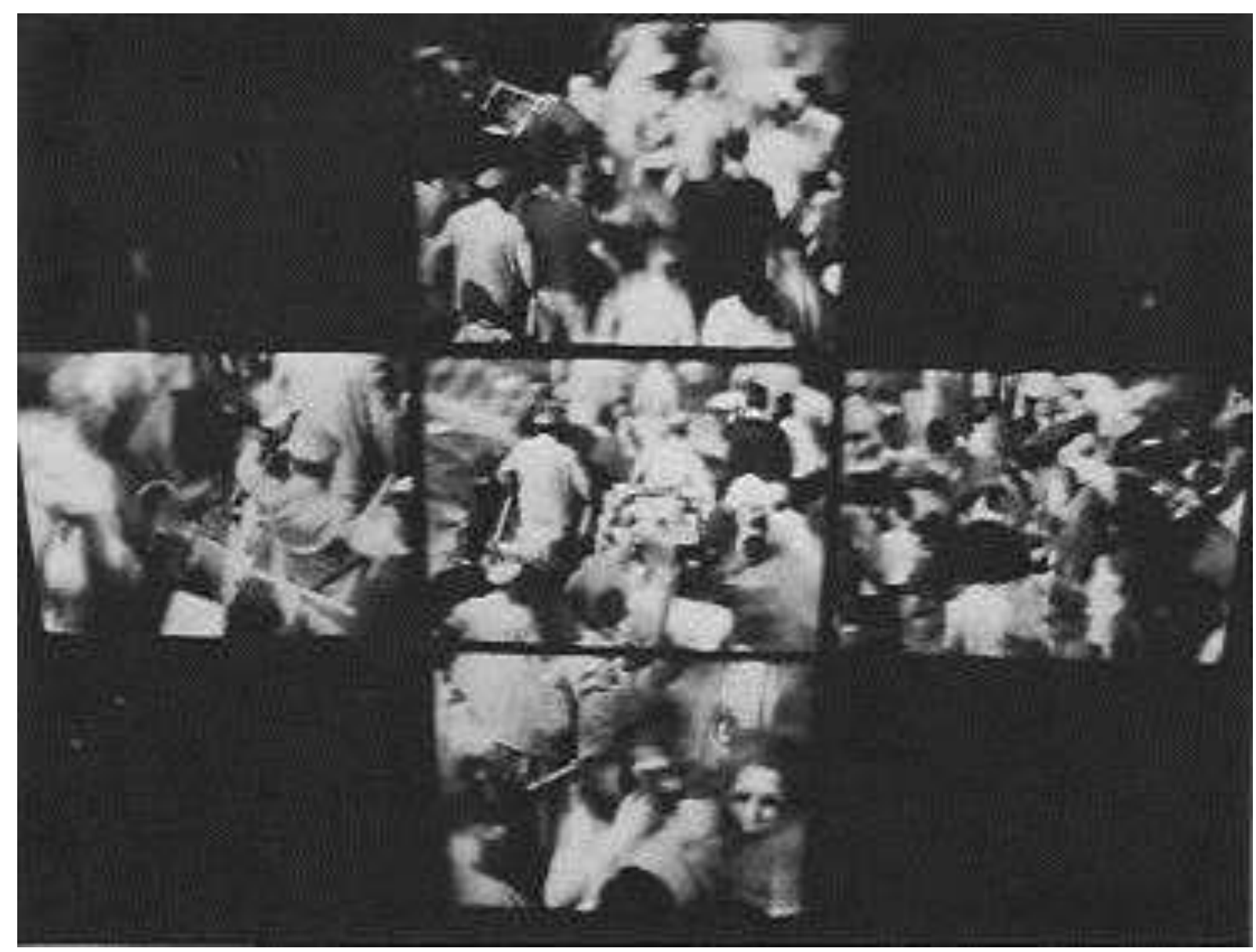

Figura 18: Roman Kroitor's Labyrinthe 1967

Sala três da obra Labirinto. Cinco telas dispostas em forma de cruz.

Fonte: Youngblood, Gene. Expanded cinema.1970, p.354

A obra Tapp-und Tastkino (1968) de Valie Export, traz um uso diferenciado da tela e do cinema. Nesta obra, segundo Thomas $\operatorname{Dreher}^{29}$ (p.17) a artista sai pelas ruas com uma caixa apoiada em seu corpo na região dos seios. Essa caixa tinha uma abertura na parte da frente, coberta com uma cortina. Export propõe aos transeuntes apalparem, tatearem através desta cortina por 12 segundos, tempo que foi controlado pela artista. Dessa forma, a obra se opõe à parte visual tradicional do cinema. "A ação que tomava lugar no palco torna-se invisível e palpável, em oposição ao visível intangível vislumbre do cinema." (DREHER p.17, tradução nossa).

${ }^{29}$ DREHER, Thomaz. Vallie Export / Peter Weibel. Multimedial feminist art. Disponível (para download em pdf) http://dreher.netzliteratur.net/2_Export.pdf (documento sem data). Acesso em 07 de junho de 2014 


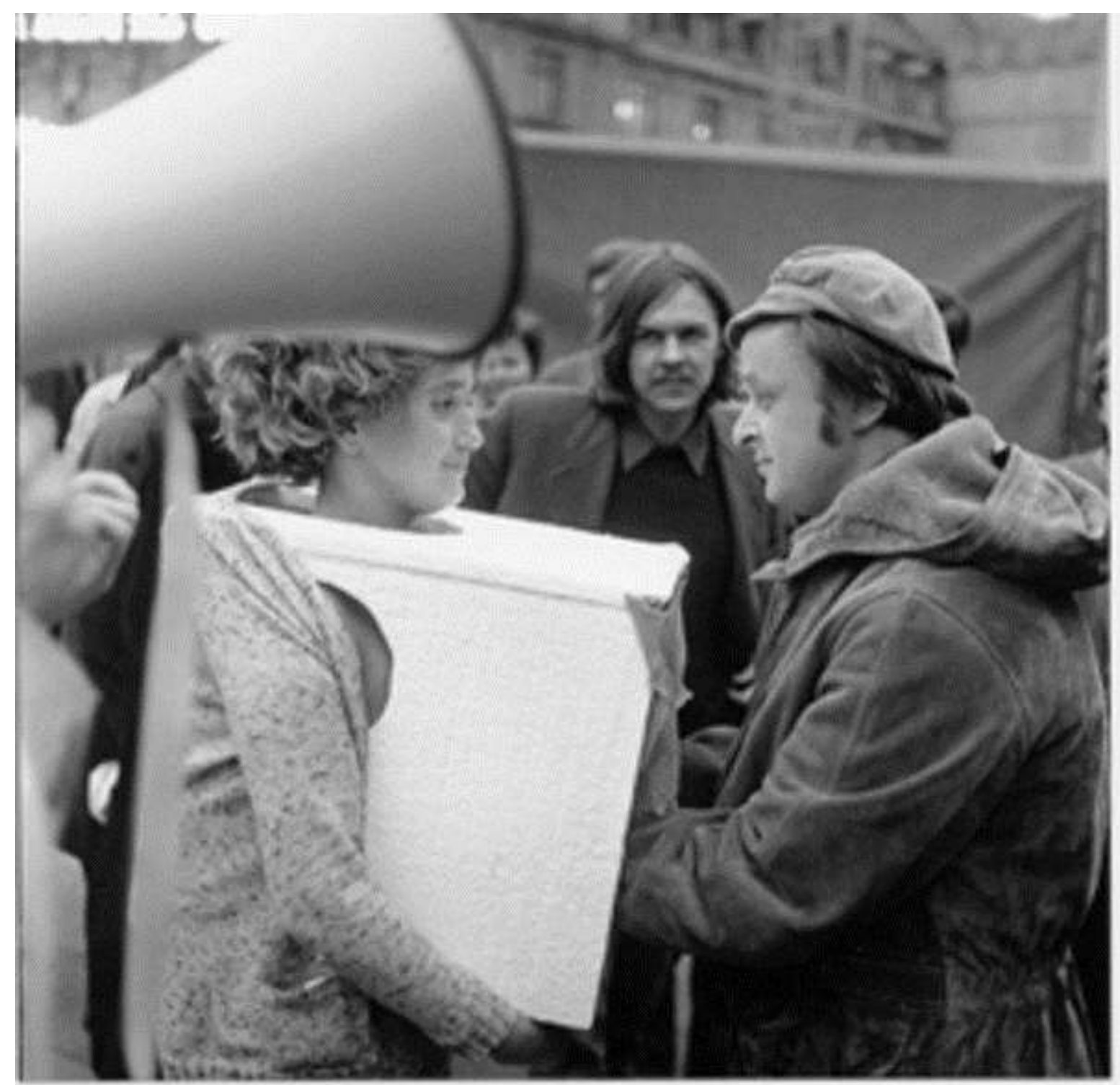

Figura 19: Valie Export. Tapp-und Tastkino 1968 Foto: Werner Schulz

Fonte:

http://www.valieexport.at/en/werke/werke/?tx_ttnews\%5Btt_news\%5D=1956\&tx_ttnews\%5BbackPid\%5D=13 $\& \mathrm{cHash}=8278689 \mathrm{e} 8 \mathrm{~b} @$ VALIE EXPORT

\subsection{O corpo como suporte da arte e relações entre corpo e imagens em movimento}

O corpo, sempre esteve presente desde os primórdios das representações e foi se tornando cada vez mais importante tanto como objeto central do olhar como integrante do campo das artes. (SANTAELLA, 2008, p. 251). E continua como objeto, como conteúdo da representação, por toda a tradição secular até o século XIX, quando ocorre, segundo a autora, uma mudança em que o corpo, muitas vezes do próprio artista, passa a ser objeto e sujeito de 
seu trabalho e começa a ser repensado. Este repensar se refere tanto ao corpo do artista como ao corpo do espectador, que passa mais fortemente a ser considerado parte integrante da obra, de modo que sem o espectador, sem sua participação a obra não existe. Como comentado no capítulo 1 nos tópicos 1.3 e 1.4), a partir da crise da representação (intensa no século XX) os artistas vão se afastando da representação "fiel" da realidade (vide a invenção da fotografia) e assim os próprios elementos materiais da pintura, como cor, pincelada, tela, moldura se tornam o próprio assunto. Segundo Santaella:

A partir de então, as telas mesmas podiam ser rasgadas. Por fim, só as molduras vazias ou as costas dos quadros foram apresentadas até a substituição da superfície da tela pela superfície da pele. A pintura como arena de ação (action painting) tornou-se ato corporal na tela, terminando em uma pintura no próprio corpo humano, uma ação sem tela, até o limite do corpo em si, encenando, seja lá o que for mesmo a inércia, se transformar em arte. (SANTAELLA, 2008, p.252-253)

Portanto, o próprio corpo do artista se transforma em suporte. Ainda segundo Santaella (2008, p.253), Duchamp, foi uma figura importante para as posteriores manifestações da arte e no quesito arte-vida, o artista transformou em arte, por exemplo, a encenação do sexo oposto, quando se personifica como Rrose Sélavy (Eros c'est la vie), e trinta anos depois dessa encenação, Pollock estende uma tela e trabalha com tintas e ação de seu corpo como parte do seu trabalho. A transformação de Pollock em utilizar o ser do artista e a ação do corpo como parte do trabalho foi estendida por outros artistas, para as performances puras, sem tela. Segundo Kaprow (2006, p. 41-42) a obra de Pollock avança pelas bordas do quadro ao passo que em "trabalhos mais antigos, a borda era um corte muito mais preciso: aqui acabava o mundo do artista; para além começava o mundo do espectador e a "realidade".(KAPROW, 2006, p.41,42) Assim, a escolha de Pollock de trabalhar telas gigantescas teve outras funções mas o que importava, para Kaprow, era que deixavam de ser pinturas e passavam a ser ambientes. A pintura se projeta para fora e assim já não somos apenas espectadores, somos participadores :

Pollock é o resultado final de uma tendência gradual que realizou um movimento desde a profundidade do espaço dos séculos XV e XVI até a construção das colagens cubistas, que saem da tela. No caso atual, a "pintura" se moveu tanto para $\mathrm{o}$ lado de fora que a tela não é mais um ponto de referência. Consequientemente, embora no alto, na parede, essas marcas nos envolvem como fizeram com o pintor enquanto ele estava trabalhando, tão estreita é a correspondência alcançada entre o seu impulso e a arte resultante. (KAPROW, 2006, p.43) 
Kaprow questiona que caminho os artistas devem seguir após esta ação de Pollock, se deviam continuar o caminho de Pollock ou desistir de fazer pinturas, referindo-se a pinturas em formato oval ou retangular como a tradicional e afirma que Pollock chegou perto disso. Os artistas deviam passar a se:

\begin{abstract}
preocupar com o espaço e os objetos de nossa vida cotidiana [...] Não satisfeitos com a sugestão, por meio da pintura, de nossos outros sentidos, devemos utilizar a substância específica da visão, do som, dos movimentos, das pessoas, dos odores, do tato. Objetos de todos os tipos são materiais para a nova arte : tinta, cadeiras, comida, luzes elétricas e néon, fumaça, água, meias velhas, um cachorro, filmes, mil outras coisas que serão descobertas pela geral atual de artistas.(KAPROW , 2006, p. 44)
\end{abstract}

Segundo Santaella (2008, p. 253- 254), esta interpretação de Kaprow em relação à obra de Pollock de 'quase- ambiente' e da tela como um campo para agir, influenciou muitos artistas que "buscaram criar uma união ainda mais íntima das marcas objetivadas de sua ação com seus estados subjetivos, físicos e psicológicos" (SANTAELLA, 2008, p.254). A autora relata que vários grupos e artistas passaram a usar o corpo para produção de obra artística como é o caso do Grupo Gutai, Zero Kai, e os vários criadores de Happening e o Grupo Fluxus. Segundo Regina Melim, outro elemento que merece ser destacado na trajetória do uso do corpo do artista, e também de diversos materiais e ambientação deve-se às aulas de John Cage no Black Mountain College de 1940 até a década seguinte e as aulas que deu sobre composição de música experimental na New School for Social Research em Nova York. Nessas aulas Cage e seus alunos repensam "a própria música não mais como sucessão de notas, harmonia e ritmo, mas como pulsação, fruição, temporalidade e espacialidade." (MELIM, 2008, p.12)

As ideias de Cage nas aulas e relatos sobre os eventos que aconteciam no Black Mountain College influenciaram muitos artistas como Allan Kaprow, Dick Higgins os artistas do Grupo Fluxus.

Segundo Roberto Cruz, dos anos 1960-70, ocorria em muitas tendências estilísticas como arte minimalista, conceitual, happenings, performances e instalações um enorme questionamento da noção de avaliação de uma obra de arte no quesito durabilidade e unicidade, princípios fundamentais nas formas tradicionais de expressão como a pintura e escultura. "Nestas propostas, com frequência, utilizava-se a linguagem audiovisual como recursos de integração dos aspectos visuais da imagem em movimento com a representação do próprio artista e de seus questionamentos culturais e filosóficos.” (CRUZ, 2012, p. 18)

Ainda segundo o autor é necessário levar em conta o contexto das artes visuais para poder "compreender o desenvolvimento do audiovisual como uma forma de arte [...]" (CRUZ, 
2012, p 18)

Nessa época, muitas ferramentas surgem mais simples, mais baratas (super-8, $16 \mathrm{~mm}$ e a câmera de vídeo portapack) para a produção de uma linguagem original e que ia ao encontro dessas tendências estilísticas. "Os artistas começaram a utilizar o audiovisual, incorporando elementos multimídia, como o ambiente em que a intervenção era realizada, a temporalidade e o próprio espectador que passava a ser evocado também como um agente do processo de criação e reflexão.” (CRUZ, 2012, p18)

O Grupo Fluxus representa a multiplicidade de arte nesse tempo e contexto. Fluxus foi um movimento intermidiático internacional e dele participaram artistas, escritores, músicos, cineastas e teve como uma das lideranças George Maciunas, que iniciou, segundo Rush (2006, p.18) os primeiros eventos do Fluxus na Galeria AG em Nova York (1961) e posteriormente em 1962, em festivais na Europa, destacando-se como um movimento anti-arte, isto é, contra a exclusividade da arte aos museus. Algumas das propostas destes artistas eram instruções para o público que de espectadores passivos passam a "participantes" tendo atuação direta nos eventos. Segundo Cruz (2012, p. 20), a Fluxfilm Antology, "reunia obras dos artistas que também se interessaram pelo cinema experimental e sua relação com as artes visuais". (CRUZ, 2012, p. 20). As obras de artistas como Paul Sharits, Yoko Ono, Dick Higgins entre outros do Fluxus "exploravam os recursos do processo cinematográfico como o slow motion (câmera de alta velocidade filmando dois mil quadros por segundo), a filmagem quadro a quadro, o reverse e a manipulação direta, aplicando letraset ou pingando tinta sobre a película." (CRUZ, 2012, p.20). Segundo Rush, "Uma estética minimalista começou a se desenvolver, herdada da poesia concreta, de manifestos dadaístas e música experimental, e estendeu-se aos filmes também, tornando-se um elemento importante no desenvolvimento da arte e meios de comunicação de massa.” (RUSH, 2006, p.19)

Essa estética minimalista, de acordo com o autor, pode ser vista em todos os aproximadamente 40 filmes chamados de Fluxfilmes realizados pelos artistas do Fluxus. Um trabalho de Nam June Paik Zen for Film (1962-64), fica como um exemplo geral dos filmes. Esse filme era de aproximadamente 1000 pés de película de $16 \mathrm{~mm}$ em branco, sem processamento, projetados, sobre uma tela por 30 minutos. Deixando o filme ao essencial: película e projeção sem imagem e sem som, Paik dava assim as costas ao mecanismo de produção de filmes de larga escala. No decorrer das apresentações, a película adquiria riscos, poeira devido ao movimento físico do filme durante a projeção, e um novo filme era apresentado a cada exibição. O filme de Paik foi exibido no Fluxhall (em Nova York, no 
apartamento de Maciunas). "Efetivamente uma instalação dos primeiros tempos (um quadro vivo consistindo em uma tela caseira de cinema, um piano vertical e um contrabaixo) [...]" (RUSH, 2006, p.19)

Outro exemplo da estética desses filmes segundo Rush (2006, p19-20), seria o realizado a partir de um roteiro de performance de Mieko Shiomi que indicava o sorriso de um artista no início da apresentação até seu desaparecimento gradual no decorrer da apresentação. O filme, de Peter Moore, realizado a partir desse roteiro mostra então um closeup da maçã do rosto, do queixo e da boca de Yoko Ono (artista participante do Fluxus), apresentando as alterações mínimas deste movimento. Filmado em 8 segundos, exibido em 11 minutos através da projeção em câmera lenta.

"As performances de Fluxus posicionavam o corpo em termos fenomenológicos, fazendo-os emergir para o mundo. Centralizavam-se no corpo como principal meio de interrogação das condições mesmas nas quais os indivíduos interagem para produzir significados sociais." (SANTAELLA, 2008, p. 255)

Ainda segundo Santaella (2008, p.255), os artistas do Fluxus pretendiam uma fusão entre arte e vida e assim apresentavam ações simples e a total concentração desses gestos.

Nos anos 60, Santaella (2008, p.257) destaca que, artistas como Yves Klein, Pierro Manzoni, Jasper Johns dentre outros inspirados por Duchamp, tiveram sedimentados seus trabalhos no contexto do corpo e estenderam o gesto de Duchamp de transformar através da assinatura os ready-mades em obra de arte; assim Manzoni assina corpos de modelos nuas como obra de arte, vende uma edição limitada de lata contendo seus excrementos (Merda d' artista, 1961), Klein usa, para pintar telas, modelos nuas que serviram de pincel e Bruce Nauman é fotografado com água saindo pela boca em sua obra Portrait of the Artist as a Fountain (1966), Nauman também explora fenomenologicamente seus movimentos faciais através da câmera lenta em 1969.

No contexto dessas obras estavam ocorrendo paralelamente, movimentos políticos por direitos e luta pela liberdade; "os artistas projetavam seus corpos contra o pano de fundo dos valores sociais contra os quais freneticamente resistiam. Desse modo, o corpo era tomado como lugar de protesto político, ideológico, estético e existencial.” (SANTELLA 2008, p, 258).

Rush ressalta que "as revoluções social e sexual dos anos 60 encontraram expressão na arte que se afastava da tela em busca de ações que incorporavam o observador à obra de arte." (RUSH, 2006 p.30) 
Santaella se utiliza de alguns conceitos de $\operatorname{Sharp}^{30}$ (1970, pp. 14-17) que afirma que os artistas não usavam seu corpo como atitude meramente biográfico; a proposta ia muito além, e o autor divide-as em três categorias:

O corpo como instrumento: se refere a toda produção em que a mão é substituída para produção de arte.

O corpo como lugar: quando ocorrem marcas transitórias ou permanentes no corpo, do que a obra Reading Position for Second Degree burn (1970) de Denis Oppenheim é um exemplo. O artista realiza duas fotos: uma antes e uma depois de seu corpo ser exposto ao sol. $\mathrm{Na}$ primeira foto deixa um livro sobre seu peito e na segunda mostra seu corpo queimado exceto onde o livro estava fixado durante sua exposição ao sol.

Corpo como pano de fundo: o corpo encontra-se em conexão com outros objetos físicos, como se observa na obra How to Explain a Painting to a Dead Hare (1965) de Joseph Beuys.

Muitas dessas obras foram registradas por fotos e/ ou filme/ vídeo, de forma que a exibição desses trabalhos quase sempre envolve monitor ou projeção. Trataremos de obras que tenham sido realizadas por meio de gestos performáticos dos artistas dirigidos diretamente para a câmera para serem exibidos em monitor, projeção ou que usem a tela no momento mesmo da ação.

Em 1965 surge o vídeo - portátil - o portapack ( Eletronic Vídeo Tape Recorder, primeiro modelo desenvolvido pela Sony, de uso doméstico, que permitia gravar e reproduzir imagens eletrônicas, mais fácil de operar, mais flexível, e barato se comparado a película de cinema e outras formas de produção de arte. Segundo Francesca Azzi (2012, p. 32), muitos artistas buscaram o encontro do vídeo com as artes e alguns trabalharam dentro do seu próprio ateliê, com a câmera voltada para si; outros trabalhavam em circuito fechado, envolvendo o público, ou criando mensagens videográficas altamente estéticas. Muitos desses artistas trabalharam em tempo real, tanto nas suas performances realizadas em estúdio como nos trabalhos com circuito fechado. Azzi relata que:

$[\ldots]$ o tempo real se encaixa nas performances e happenings. As imagens de cinema, caras e quase sempre restritas aos modelos narrativos cinematográficos passam a ser metaforicamente demolidas numa reconstrução de novos e infinitos sentidos. $\mathrm{O}$ filme/vídeo se vê integrado ao universo cósmico das artes e ocupa museus e galerias. O pensamento vanguardista estava correto: à arte não caberia restrições linguísticas, nem técnicas, nem espaciais. (AZZI, 2012 p. 32)

\footnotetext{
${ }^{30}$ SHARP, Willoughby. A pre-critical, non-definitive survey of very recent works using the human body or parts thereof. Avalanche, Autumn, 1970, pp. 14-17.
} 
Segundo Rush;

O vídeo também proporcionou uma sensação de intimidade geralmente imperceptível no filme. Nas mãos de artistas como Vito Acconci e Bruce Nauman, que literalmente viravam a câmera para si mesmos em situações fabricadas (Acconci) ou no estúdio (Nauman, Howard Fried), o vídeo tornou-se uma extensão do gesto artístico há tanto tempo associado à pintura, e principalmente aos expressionistas abstratos, que enfatizaram o próprio ato físico de pintar. Com o vídeo, era possível gravar o gesto do artista e observar seu corpo no ato da criação. (RUSH, 2006, pp. 78-79)

Abordaremos algumas obras que trabalhem com ações performáticas para a câmera e suas formas de exibição, iniciando com a exibição tradicional com o monitor e projeção em single channel, para passarmos a vários monitores e projeções.

Segundo Melim (2008, p.47), por volta de 1960-70 quando como dito acima, surgem as câmeras de vídeo portáteis, leves e baratas, estas foram incorporadas por artistas como Bruce Nauman, Vito Acconci, John Baldessari, que as apontaram para si e realizaram suas obras através da repetição de gestos diante da câmera e não de um público, como em: Walking in an exaggerated manner around the perimeter of a square (1967-1968), de Bruce Nauman, Face off de 1972 de Vito Acconci e I am making art (1971), de John Baldessari.

A autora (2008, pp.47-48) indica que esses procedimentos foram empregados no final de 1960 e continuam até o presente citando mais alguns artistas que trabalham dessa maneira, isto é, trabalhos endereçados a vídeo ou fotografia: Carolee Scheemann, Vito Acconci, Bruce Naumann, Richard Serra, Dennis Oppenheim, Bas Jan Ader, Francesca Woodman, Joan Jonas, Marta Rosler, Cindy Sherman, Paul McCarthy, Tony Oursler, Matthew Barney, Orlan, Gillian Wearing, Pipilotti Rist etc.

Ainda segundo a autora, no Brasil não foi diferente e por volta de 1970, os artistas da considerada primeira geração produziram obras em vídeo que consistiam no registro das ações performáticas diante da câmera. Segundo Mello (2008, p.144), o vídeo foi intensamente trabalhado dessa forma devido à proibição de manifestações públicas no Brasil, que não eram permitidas pelo Estado ditatorial, o que explica a maioria de os trabalhos performáticos serem realizados em caráter privado e documentados pela câmera.

Neste sentido, Machado (2007, p. 17) lembra que o vídeo era muito usado na época da ditadura militar, por não necessitar de laboratórios de revelação ou de sonorização que, então, eram nessa época centros de vigilância de produção. Os artistas da primeira geração de videoarte no Brasil eram na grande maioria: 
Como se sabe, a partir de meados da década de 1960, muitos artistas tentaram romper com os esquemas estéticos e mercadológicos da pintura de cavalete, buscando materiais mais dinâmicos para dar forma às suas idéias plásticas. Entre os que se aventuraram para fora dos espaços tradicionais da arte, houve aqueles que foram buscar materiais para experiências estéticas inovadoras nas tecnologias geradoras de imagens industriais, como é o caso da fotografia, do cinema e sobretudo do vídeo. [...] é impossível compreender a primeira videoarte fora desse movimento de expansão das artes plásticas ou de reapropriação dos processos industriais, que já havia antes acumulado experiências no terreno do audiovisual (projeção de diapositivos) e do cinema de $16 \mathrm{~mm}$ ou Super -8 (Antonio Dias, Barrio, Iole de Freitas, Lygia Pape, Rubens Gerchman, Agrippino de Paula, Arthur Omar, Antônio Manuel e o próprio Oiticica). ( MACHADO, 2007, p. 17)

No Brasil, dentro deste contexto, temos a obra de Letícia Parente (dentre outros artistas), que trabalha o corpo e que introduziu junto de uma geração de artistas "o portapack no contexto das artes visuais brasileiras [...].” (AZZI, 2012.p. 40)

Segundo Melin (2008, p. 48), muitos outros artistas no Brasil trabalham com esses procedimentos: Letícia Parente, Sônia Andrade, Anna Bella Geiger, Iole de Freitas, Rafael França e mais recentemente: Lenora de Barros, Amilcar Packer, Janaína Tschäpe, entre outros.

Ainda segundo a autora (2008, p.49), esses artistas que realizam ações diante da câmera (de vídeo ou fotográfica), instauraram seu corpo "como matéria artística, eleito, muitas vezes, como lugar de desdobramento das categorias escultura e pintura." (MELIM, 2008, p. 49)

Carolee Schneemann, por exemplo, em Eye body (1963) utiliza como superfície pictórica seu corpo e seu ateliê. Segundo a própria artista:

I'm still a painter and I will always be in essence a painter .... Painting doesn't have to mean that you're holding a brush in your hand. It might or it might not. It might be a camera. It might be a microphone. It might be your own body that when you go inside the frame and when you adjust your focus you see that the materiality of what you're working with might include yourself in a force field. (SERRA; RAMEY 2007, p. 103):

Para Melim (2008, p. 49), as sequências de fotos de Carolee nessa obra podem ser consideradas as precursoras das ações sem audiência ainda antes das câmeras de vídeo.

Bruce Nauman também trabalhava com ações para a câmera sem audiência e as apresenta em monitor. Ele faz parte da primeira geração de vídeo surgida nos EUA. Segundo Melim (2008, p. 49) o artista entendia que sendo ele um artista e estando em seu ateliê, tudo que produzisse ali, resultaria em um trabalho artístico; ele pretendia enfatizar o processo como obra. Melim (2008, p. 50) acrescenta que atualmente esse espaço chamado ateliê expandiu-se para ser "qualquer lugar", passando a ser onde o artista está. 
Nauman tratava essas ações que realizava nos seu estúdio como uma extensão de sua escultura. Realiza "uma série de atividades corriqueiras como sentar, caminhar, inclinar o corpo ou se agachar, o artista criava uma sequência ininterrupta de "esculturas vivas', nomeando-as pelo sugestivo título de representações. ” (MELIM, 2008, p.51)

A autora exemplifica com alguns trabalhos do artista, como Wall/floor positions (1968) em que ele tratava seu corpo como um objeto escultórico. Nesta obra o artista realizava uma série de movimentos em relação à parede e ao chão de seu ateliê.

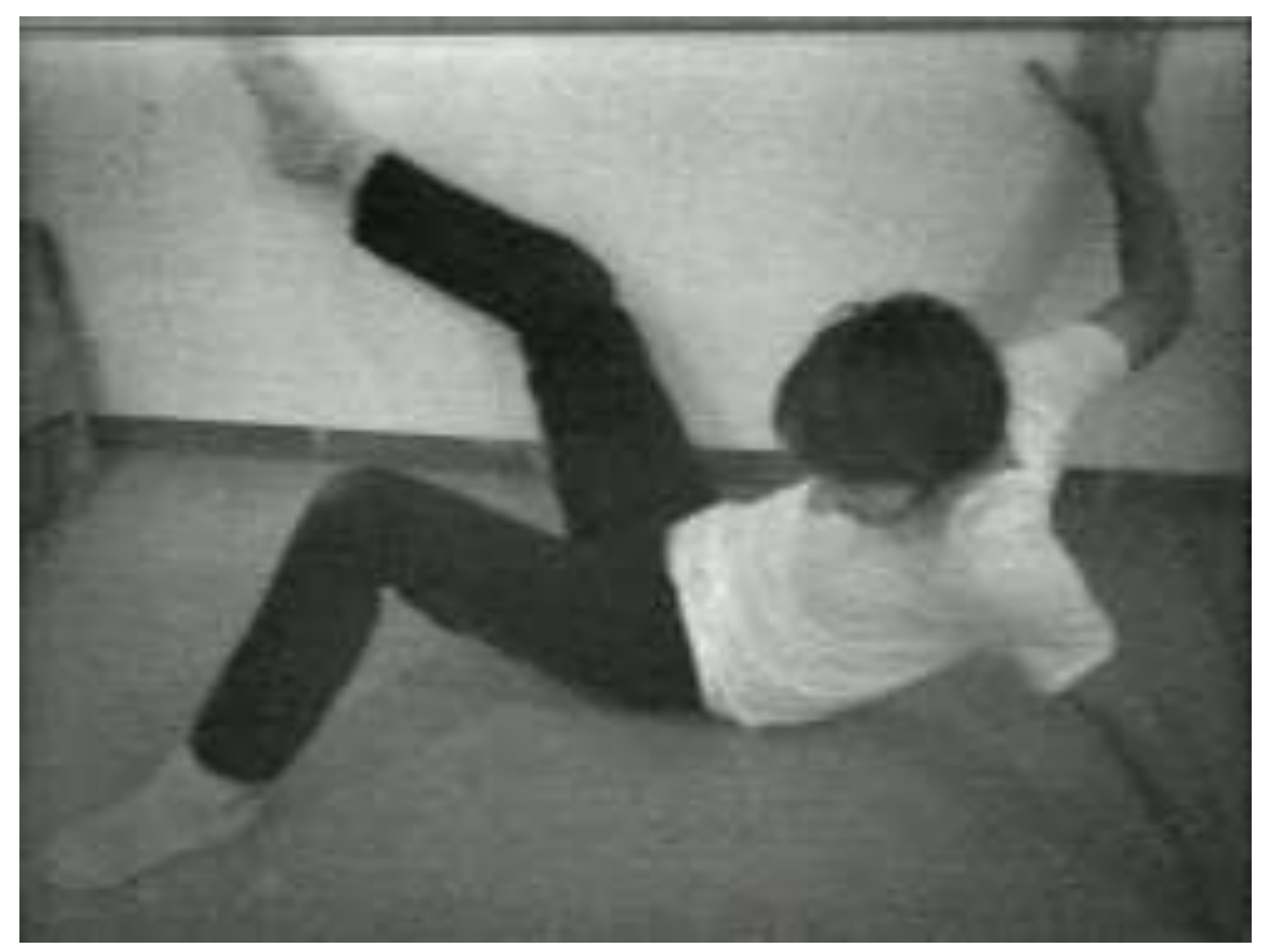

Figura 20: Bruce Naumann. Wallfloor positions. 1968

Fonte: http://www.eai.org/title.htm?id=4287

Também segundo Melim (2008, p. 52) ocorrem práticas deste tipo em séries autobiográficas/ autorreferentes muito comuns desde 1970 até hoje. Bas Jan Ader, em seu I'm too sad to tell you (1970), é um exemplo desse tipo de obra . O artista aparece chorando por alguns minutos em frente à câmera. 


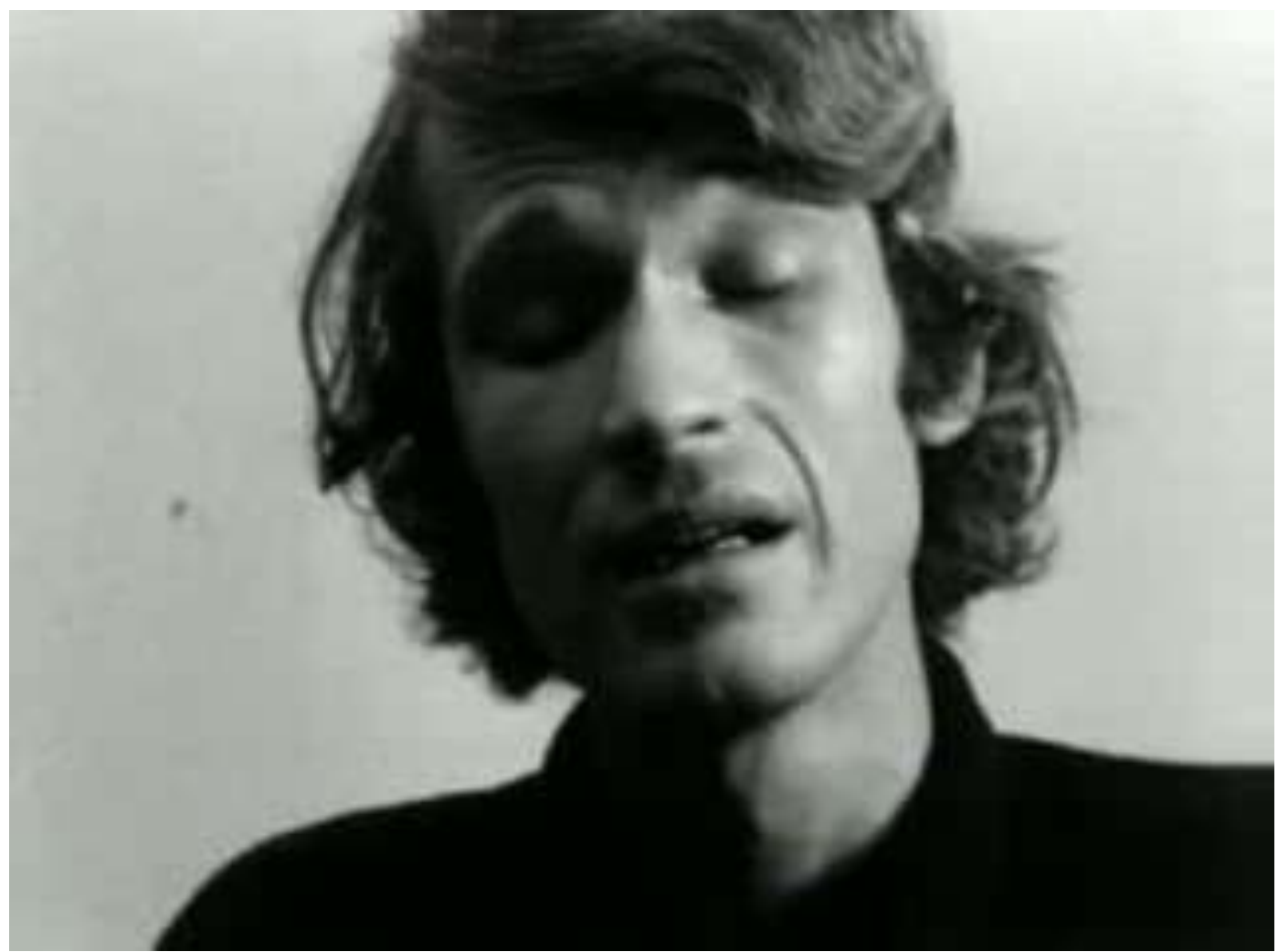

Figura 21: Bas Jan Ader. I'm too sad to tell you .1970

Fonte: http://artforum.com/video/id=20457\&mode=large\&page_id=16

Santaella (2008, p. 263) destaca, baseada nos escritos de Jones (2000, p.22), que a body art em um primeiro momento era mais ligada ao corpo do artista, muitas vezes ligado a auto flagelação, diante de uma plateia, em um determinado local, mas indica que este tipo de obra foi sendo menos intensa. A partir de 1980 as artes do corpo do artista voltam-se mais intensamente para "autoperformance fotográfica e para o videoperformativo, intensificando a tendência performativa do eu-como-imagem, dos simulacros do eu." (SANTAELLA, 2008, p.263)

No que se refere ao corpo do artista, Santaella baseia-se em escritos e conceitos de Jones: "frente à mercantilização dos corpos e dos egos próprios do pancapitalismo, a estratégia de muitos artistas foi a de exagerar, de maneira parodística e potencialmente crítica, os simulacros do eu e do corpo em um mundo reificado. (SANTAELLA, 2008,p.264)

Assim, nos anos 80 os artistas usam a fotografia e com muita intensidade o vídeo. Segundo Santaella (2008, p. 267) baseada nos escritos de Krauss na sua Estética do Narcisismo (1976). O corpo humano é um instrumento essencial e o vídeo é fundamentalmente arte do corpo e quase sempre do corpo do artista. Já a videoinstalação, o corpo é quase sempre do espectador. Pela sua capacidade de gravar e transmitir 
simultaneamente as imagens, o vídeo difere das outras artes visuais e o corpo fica entre duas máquinas: a câmera e o monitor que reprojeta a imagem do performer imediatamente como um espelho. Já nos anos 90, ainda segundo Santaella (2008, p. 268), as experimentações e relações do corpo do artista e vídeo se intensificam com a hibridização do vídeo,isto é, a videoinstalação. Nessa época o corpo ainda é muito utilizado, mas difere do corpo vivo do artista das décadas de 50 a 70. Agora ele aparece "fragmentado, estilhaçado ou encenado por meio de elaboradas transferências para as instalações ruptoras"

Do exposto, concluímos que as obras do primeiro período de ações performáticas para a câmera, em sua grande maioria, foram exibidas em monitores. Posteriormente, essas ações performáticas realizadas para a câmera são exibidas por diversos monitores, por múltiplas projeções ou por telas diferentes. Veremos no capítulo 3 no tópico 3.4.5, o trabalho Pintura em atos como um exemplo de ação performática exibida em videoinstalação, na qual, além do corpo do artista, a obra também requer um deslocamento do espectador pelo espaço.

Santaella (2008, p.276) divide em duas grandes tendências, as obras contemporâneas que trabalham o corpo: as refrações do corpo e as memórias do corpo.

A autora afirma ter escolhido o termo "refrações", porque "o tratamento que vem sendo dado ao corpo na arte tem uma ambiguidade que não pode ser confundida com a mera deformação ou distorção de sua aparência física. Uma ambiguidade que tem algo de transcendental.” (SANTAELLA, 2008, p.276)

Ela explica essa característica com alguns exemplos, como a pintura de Francis Bacon e a escultura de Jake e Dinos Chapman, artistas ingleses criadores de obras de figura humana que parecem realistas mas, sob essa aparência, surgem figuras absurdas, monstruosas, anomalias genéticas. Em vídeo, a autora afirma ter diversos exemplos, já que o vídeo tem o como característica intensa, o narcisismo, que foi apontado por Krauss. Em vídeo são obras que têm o corpo do artista como objeto de experimento. O que se nota tais em Marca Registrada (1975), de Letícia Parente, em que a artista borda diante da câmera Made in Brasil na sola de seu pé, e a instalação de Bruce Nauman Raw Material BRRR (1990). Nela o artista critica a imagem harmoniosa do humano, usando para isso dois monitores superpostos que exibem a mesma imagem de seu rosto invertida e uma grande imagem projetada semelhante na parede adjacente nas quais o artista profere com os lábios um BRRR sem sentido, diferente das cabeças vistas nas TVs. 


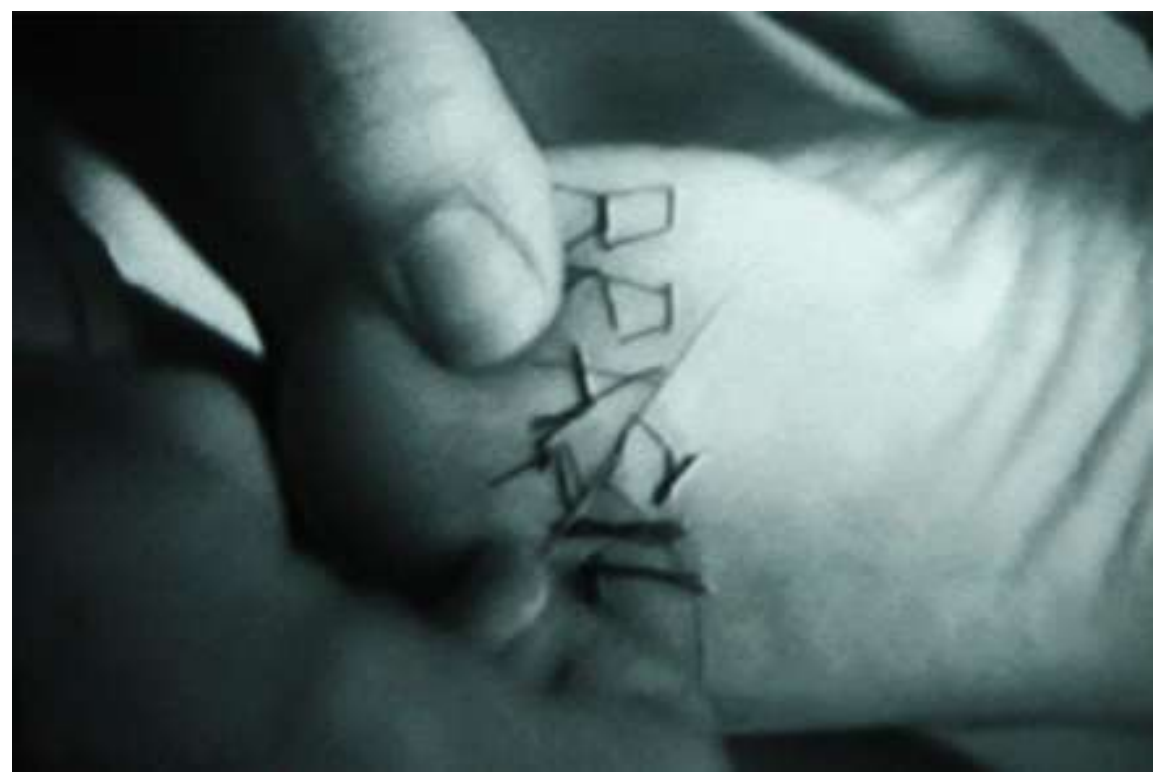

Figura 22: Letícia Parente. Marca registrada. 1975

Fonte: http://arteref.com/video/marca-registrada-leticia-parente/

Em memórias do corpo, a segunda tendência de Santaella os artistas voltam-se para registrar as vezes insolitamente a fisicalidade de seus corpos. A autora afirma que esses trabalhos poderiam ser entendidos "como moldes, memória indelével de um corpo cuja compleição, dimensão, contorno físico estão em vias de mutação." (SANTAELLA, 2008, p.280). A autora destaque essa tendência com vários exemplos e afirma que "No vídeo, a tendência narcisista que lhe é própria produz obras que se enquadram não apenas nas "refrações do corpo", mas também na "memória do corpo", esta manifesta na obsessiva necessidade do registro corporal." (SANTAELLA, 2008, p. 280-81)

Um dos vários exemplos é o trabalho de Neide Jallageas Entrevista (2000) em que ocorre a autorreferencialidade do registro vídeográfico. A artista apoia a câmera sobre seu corpo e essa mira seu rosto. Os movimentos de câmera e sons são criados pelo próprio corpo da artista durante sua respiração; no decorrer do tempo ouvem-se barulhos de disparo fotográfico, executados pela própria artista.

Estas duas classificações feitas por Santaella em relação ao corpo na contemporaneidade serão observadas também em uma série de nossa autoria intitulada Autorretrato com duração e sons variáveis que será abordada nesta dissertação no capítulo 3 tópico 3.4.2).

De acordo com todas essas características e trabalhos realizados com o corpo, principalmente do artista, Santaella (2008, p.300) afirma que os corpos aparecem como 
vestígios analógicos em cinema, foto e vídeo, pois são registros realizados por uma câmera. $\mathrm{Na}$ foto e no cinema são photons que se inscrevem na superfície do filme e no vídeo são inscrições luminosas. Desta forma os corpos, que são registrados por câmeras continuam sendo analógicos e assim eles "ainda mantém suas qualidades espaciais e temporais na sua inscrição luminosa". (SANTAELLA, 2008, p. 300). Mas, esses corpos ao serem colocados em bancos de base de dados eletrônicas embora continuem sendo indiciais são transmutados em dados simbólicos e podem ser infinitamente manipulados em "mesas e menus de processamento, adquirindo uma existência sintética muito diversa da natureza analógica que os fixa em fotogramas de natureza química." (SANTAELLA, 2008. p.300).

Com as grafias informacionais surge um novo tipo de corpo, o corpo infográfico e este não depende de nenhum registro, ele pode ser totalmente criado por algoritmos.

Os corpo indiciais manipulados em mesas de menu serão também vistos em algumas obras no capítulo 3 a partir do tópico 3.4 . 


\section{Capítulo 3: Cinema de Exposição}

\subsection{Percurso das imagens em movimento nos museus.}

Traçaremos um panorama da migração das imagens em movimento e do aparato associado principalmente ao cinema da sala escura tradicional aos espaços tradicionais da arte, para posteriormente estudarmos as características de trabalhos de artistas, que diferenciem, ampliem o conceito, suportes, práticas do cinema tradicional, trabalhem com telas diferenciadas da padronização do cinema de sala, utilizem procedimentos de artes visuais na escolha de materiais físicos e simbólicos em que projetam imagens, retomando procedimentos de pré-cinema, ao produzirem obras fantasmagóricas.

Nos espaços de arte onde víamos, a princípio, quadros e esculturas, posteriormente foram também nos sendo apresentados objetos, assemblages, materiais diversos, de duráveis à efêmeros, obras em processos mais do que objetos e contemporaneamente com mais frequência imagens projetadas.

A migração de imagens em movimento projetadas que se deslocam da sala tradicional de projeção aos espaços de arte trouxe consigo desdobramentos que ampliaram os modos do espectador de se relacionar com as imagens em movimento e nos apresentaram a diversidade de práticas artísticas associadas a essa pesquisa, como uso de materiais, formas de apresentação, recepção e durações variadas.

O termo "cinema de exposição" foi utilizado pela primeira vez pelo crítico francês Jean- Christophe Royoux, para designar essa migração e seus desdobramentos.

Segundo Dubois, o cinema de exposição:

[...] designa, na verdade, um conjunto de propostas dos artistas que procuram utilizar diretamente o "material" filme em sua obra plástica, ou inventar formas de apresentação que se inspiram (ou fazem pensar) em efeitos ou formas cinematográficas (o "modelo cinema"), embora tendam a subverter o ritual tradicional de recepção do filme (sala escura, espectador sentado em sua poltrona, duração padrão imposta etc.). Nessas novas exposições, (re)inventa-se a tela múltipla (desdobrada, triplicada, em linha, oblíqua, em paralelo, em frente e verso), projeta-se na luz ou em objetos que não se reduzem a superfícies planas, põe-se o filme numa cadeia infinita (entramos e saímos ou, melhor, passamos na hora e no ritmo que quisermos), experimentam-se novas posturas dos espectadores (de pé, sentado, deitado, móvel), explora-se a duração da projeção (breve, muito breve, muito longa, infinita). Etc. E tudo isto se faz totalmente "em vídeo" (DUBOIS, 2004, p.28).

Esse fenômeno, observado, mais intensamente nas práticas artísticas da contemporaneidade, não é inédito, ele tem seu histórico nas origens do cinema, quando ainda 
não havia uma forma fixa de apresentar as imagens projetadas, e também nas práticas artísticas do cinema de vanguarda, experimental e expandido, como apontado no capítulo 2. Embora algumas dessas obras trabalhem retomando filmes e o legado adquirido temporalmente por eles difira dos primeiros tempos do cinema, em que ainda não havia toda essa produção, apontamos que as formas de exibição são semelhantes, no sentido de não haver um modelo único de apresentação das imagens.

Hoje, nas exposições, galerias de arte, espaços expositivos, as projeções, suportes de projeção de imagens, narrativas, arquitetura, tempo de exposição das imagens apresentadas são diferentes do cinema convencional (sala escura, arquitetura herdada do teatro italiano, projeção em uma única tela gigante, espectador sentado, taxa de 24 quadros projetados por segundo, filmes narrativos com duração de uma a duas horas).

Segundo Dubois, o vídeo possibilitou mais intensamente a invasão das imagens em movimento nos espaços de arte e deu continuidade aos processos iniciados nesse sentido pelo cinema experimental e os chamados filmes de artista. "O vídeo representou um papel central de intercessor. Entre cinema, televisão e artes plásticas, ele realizou a transição, teceu ligações que (re) modelaram a paisagem da arte.” (DUBOIS, 2003, p. 7)

O cinema, segundo Dubois, é repensado, reformulado, retomado, fragmentado pelo vídeo. O cinema nos acostumou, nos mostrou e fez nosso pensamento ser modificado, adaptado a imagens em movimento, foi o cinema "que deu movimento às imagens, que nos impregnou dessa cinematicidade do visível.” (DUBOIS, 2003, p.6).

Essa cinematicidade foi sendo naturalizada gradualmente. Temos exemplos da não aceitação inicial das formas apresentadas pelo cinema.. Nem tudo que era projetado era aceito perceptivamente pelos espectadores. Segundo Aumont o close, por exemplo, que se torna posteriormente um efeito estético específico do cinema, era visto no início como forma monstruosa; uma cabeça não poderia se mover sozinha, "isso parecia contra a natureza". (AUMONT, 1993, p.141).

De acordo com Dubois (2003, p.6), o cinema durante três quartos de século foi a única forma de nos relacionarmos com a imagem em movimento e essa relação se dava na maioria das vezes na sala de projeção, longe dos espaços expositivos da arte. Quando surge a TV, esta não é vista como ameaça ao cinema, já que não tinha o tamanho majestoso da tela do cinema e nem era projetada.

[...] e nosso pensamento sobre a imagem como movimento não tinha nenhum outro modelo: o enquadramento móvel, a duração de um plano, as travessias de profundidade por um olho virtual que se desloca, a dinâmica do extra-campo, as formas de montagem, os encadeamentos de imagens, os deslizamentos de pontos de 
tomada, toda a fluidez do tempo e do espaço, tudo isso nos chega (nos chegava?) quase exclusivamente pelo cinema como forma de pensamento (DUBOIS, 2003, p.6)

Após o aparecimento e rapidamente a dominação da televisão no universo da cultura de massas surge a videoarte. Os primeiros trabalhos de videoarte, foram realizados por Wolf Vostell e Nam June Paik em instalações, performances que consistiam de intervenções físicas diretas em aparelhos de TV, como amarrar, queimar, enterrar televisores, numa demonstração de ataque ao meio dominante de comunicação de massa.

A videoarte, por volta de 1960 e 1970, continua as experimentações dos artistas do início do século XX e do cinema experimental, aumentando ainda mais as potencialidades dessas experimentações. Segundo Machado (1997, pp.247-248), de todas as imagens, a do vídeo é a mais maleável, manipulável.

Além da pesquisa plástica na própria imagem, isto é, mudanças de luminância, cor, fusão de imagens, inserção de imagens de um contexto em outro, os artistas da videoarte pesquisaram intensamente os modos de apresentação dessas imagens em movimento.

O vídeo se inspira no cinema, mas traz com ele novas possibilidades, como as incrustações, tratamento artificial das cores, a variação de velocidade (câmera lenta, acelerada etc). Além disso, o uso de sintetizador de vídeo introduzido e utilizado por Paik e Shuya Abe possibilitou "gerar padrões imagéticos a partir apenas dos constituintes eletrônicos [...]. Ele pode operar modificando ou desintegrando a imagem dada pela câmera de vídeo, como pode também prescindir dela.” (MACHADO, 1988, p.122).

$\mathrm{O}$ vídeo trouxe também alterações nos dispositivo, como o circuito fechado, onde a tela apresenta o que está acontecendo diante dela em tempo real ou com variações entre tempo de acontecimento e aparição deste no monitor.

Segundo Dubois, (2009, p.190), no final de 1970, com a chegada e popularização dos videocassetes domésticos, as imagens podem ser facilmente armazenadas e retomadas, podendo o vídeo utilizar-se de imagens já existentes, dentre elas, as imagens cinematográficas, que foram manipuladas e modificadas, "o que se chamou de 'cinefagia do vídeo'.” (DUBOIS, 2009, p.191).

Nessa época também, o vídeo começa a deixar de ser somente exibido em festivais e sua presença é intensificada nos espaços institucionais de arte, levando assim, as imagens do cinema, retomadas e modificadas, para o campo das artes.

Os artistas do vídeo manipulam a superfície das imagens, (a fisicalidade do suporte vídeo), exploram também a disposição dos monitores plasticamente, o que veio a ser chamado 
de videoesculturas.

De 1990 a 2000, Dubois (2009, p.192) aponta a invasão de imagens em movimento em grande escala devido ao desenvolvimento de tecnologia de projetores de vídeo em grandes formatos.

[...] projetava-se assim imagens de vídeo nas paredes do museu ou da galeria, ou em grandes telas suspensas, que podiam rivalizar, em tamanho, com a imagem de cinema, e precisavam, como ele, da escuridão do espaço. Desenvolvendo-se assim, o vídeo acabou não somente por ganhar terreno (ao contrário, poderíamos dizer, já que ele abandonou pouco a pouco suas especificidades da imagem), mas, principalmente, por fazer outras artes ganharem terreno, e, em particular, por favorecer o desenvolvimento das trocas entre cinema e arte contemporânea. (DUBOIS, 2003, pp, 6-7)

Com a facilidade proporcionada pelo desenvolvimento e pelo barateamento de projetores as imagens ficam livres do monitor e os artistas as projetam nas paredes, em espelhos, em várias telas simultaneamente e em outros suportes diferentes da tela cinematográfica. Para Rush (2006, p.158-159) foi em meados de 1990 que a produção de vídeo desenvolveu maior vínculo com o cinema, o que se deveu à popularização das câmeras digitais e equipamentos mais sofisticados de edição, como os sistemas não lineares. Foi também a tecnologia digital, segundo Païni (2008), que permitiu de forma mais fácil a retomada em loop de uma mesma sequência que, anteriormente, poderia ser dificultada pelo enrolamento de uma fita (película ou magnética), e possibilitou “ [...] o efeito de quadro, o efeito pictórico da imagem animada projetada - o que foi bem explorado por Bill Viola, por exemplo, e seus efeitos imperceptíveis de câmera lenta" (PAÏNI, 2008, p.30).

$\mathrm{O}$ vídeo, no decorrer de sua curta história $(30$ anos $){ }^{31} \mathrm{e}$ de suas grandes formas (da fita de vídeo à instalação, do monitor à vídeo-projeção), introduziu progressivamente, mas de modo durável, a imagem movimento nos lugares da arte. E levou o cinema com ele. O cinema como linguagem como potência, como dispositivo (o movimento, a luz, a projeção, a imaterialidade etc) desde então faz parte integrante do campo da arte (DUBOIS, 2003, p.7).

Nos espaços da arte, as imagens em movimento, segundo Païni (2008) são apresentadas com durações diferenciadas. Por exemplo, um trabalho pode durar horas, como veremos adiante na obra de Douglas Gordon, 24 Hour Psycho (1993), com 24 horas de duração. A alteração de duração, a inserção de câmeras lentas e o espaço em que estas obras estão inseridas, faz com que a recepção seja diferenciada. Nestes espaços a recepção das imagens em movimento é semelhante à da TV. Os espectadores andam, caminham, falam, diferentemente do silêncio absoluto do cinema. $\mathrm{O}$ cinema exposto, segundo o autor, é mais

${ }^{31}$ Atualmente em 2014, são mais de 40 anos. 
sensorial, desta forma, se aproxima do cinema antes do modelo narrativo. "Os primeiros filmes, quase sem histórias, privilegiavam a acuidade sensorial” PAÏNI (2008, p.35). O autor também atribui essa acuidade sensorial à atmosfera cultural de 1990, ligada à música tecno, repetitiva.

\begin{abstract}
Mais do que significado, busca-se a sensação; a sensorialidade contra o sentido; prevalece a adulação dos sentidos, mais do que a complexidade dramatúrgica, que dificilmente se realiza quando o corpo do espectador está em movimento, não cativo em uma poltrona. Portanto, o efeito cinema se confunde com um efeito plástico, ao menos com o que supomos ser sensorial no efeito plástico.[...]. O cinema exposto oferece a possibilidade de ver de perto a imagem em movimento projetada e, sobretudo, a liberdade de variar essa distância e de se afastar dela à vontade, ao contrário do espetáculo cinematográfico, que guardou a memória de um dispositivo teatral restritivo (PAÏNI, 2008, p.30-31).
\end{abstract}

O tempo de exibição, dota de características plásticas, sensoriais as imagens projetadas, e o tempo de observação dessas imagens pelo espectador é modificado.

Para Groys (2011, p.126-127), o tempo de contemplação das imagens é modificado com a mudança de contexto, isto é, as imagens em movimento instaladas nos museus. Segundo o autor, tivemos tradicionalmente duas formas de controlar o tempo diante das imagens: a imagem está imobilizada no espaço expositivo e nosso corpo em movimento (exemplo, a pintura) ou as imagens estão em movimento e nosso corpo imóvel (exemplo, no cinema). Ambas as formas se modificam quando as imagens em movimento são deslocadas para museus. Neste contexto, nosso corpo está em movimento e as imagens também. Essas obras baseadas no tempo não possibilitam serem vistas totalmente em exposições, ainda mais quando são numerosas ou muito longas.

O propósito dessas imagens "[...] é dar uma olhada nela e depois dar outra olhada e outra olhada - mas não a ver na sua totalidade [...] pode-se dizer que o próprio ato da contemplação é colocado em loop" (GROYS, 2011, p.127).

Para o autor, nesses espaços de arte a contemplação das obras é fria. Ele se utiliza dos conceitos de McLuhan, isto é, a arte com base no tempo. Nesses espaços, a arte não pode ser vista em sua totalidade (quando existem muito trabalhos baseados no tempo ou trabalhos em tempo longo demais) e não conseguimos nos concentrar na obra (totalmente), o que é uma característica de mídias frias.

Todas essas modificações: a postura dos espectadores diante das imagens em movimento, as diferenças de apresentação das imagens em relação ao modelo padrão do cinema convencional, os espaços em que se apresentam que vão além da sala de projeção, e 
também as mudanças de suportes do cinema, isto é, de fotoquímico, para eletrônico e digital, ou todos estes suportes mesclados, geram as perguntas: Isto é cinema? O que é o cinema? Isto ainda é cinema?

Tais mudanças e questões são vistas e rotuladas na contemporaneidade por muitos teóricos, como Raymond Bellour, Pascale Cassagnau, por conceitos como "pós-cinemas", "outro cinema", "terceiro cinema", "cinema de exposição" e, por Dubois, que trabalha tanto o termo cinema de exposição como usa o termo "efeito cinema" que seria o uso de formas artísticas que se inspiram mas cometem desvios no modelo cinema e de sua linguagem (sala escura, projeção, espectadores sentados, imagens em sequência, campo, contracampo etc.)

\subsection{Artistas e procedimentos}

Diferentemente da forma de apresentação do cinema tradicional, que se utiliza da sala escura, espectador sentado, uma única tela que reflete imagens aos espectadores, os artistas na contemporaneidade utilizam procedimentos de imagens em movimento na maioria das vezes projetadas em espaços de museus e galerias com formas diferentes da apresentação desse cinema tradicional.

Philippe Dubois ${ }^{32}$ (p.16-75) divide as propostas desses artistas em dois grandes grupos e figuras. Um grupo é composto por artistas que trabalham com o material fílmico e o outro é formado por artistas que trabalham o aparato do cinema. Dentro desses dois grandes grupos o autor ainda divide as obras em oito figuras do "efeito cinema", que comentaremos adiante. A partir dessa divisão de conceitos e reflexão do teórico faremos a nossa, focando os artistas que trabalham a tela, o suporte de projeção diferentemente da tela tradicional de cinema.

Segundo Dubois, dentro do primeiro grupo de artistas estariam, os que trabalham o material fílmico. Neste, os artistas se apropriam e modificam imagens já consagradas, produzidas pelo cinema.

Esses artistas trabalhariam nas seguintes figuras:

Filme exposto: nesta figura os artistas apresentam em uma ou várias telas, os filmes já clássicos e que já povoam nosso imaginário, produzindo-lhes algumas alterações,

\footnotetext{
32 DUBOIS, Philippe. Cinéma et art Contemporain: vers un Cinéma D'exposition? De la migration d'un dispositif Ouvrage en préparation (version de travail) - versão de trabalho, gentilmente fornecida pelo autor durante palestra na ECA USP em 2013.
} 
como o prolongamento do tempo de projeção de suas imagens. Como exemplo, temos o trabalho de Douglas Gordon, que retoma Psycho (1960) de Hitchcock, de 109 minutos, e o transforma em uma videoinstalação, 24 Hour Psycho (1993), com 24 horas de duração. Ainda do mesmo artista, temos a obra Déjà vu (2000), na qual ele retoma D.O.A, um filme noir hollywoodiano e, o apresenta em três telas justapostas com diferenças mínimas de tempo de projeção que serão mais bem percebidas no decorrer do tempo. Os artistas desta figura também apresentam filmes já conhecidos, mas dissociam som de imagem.

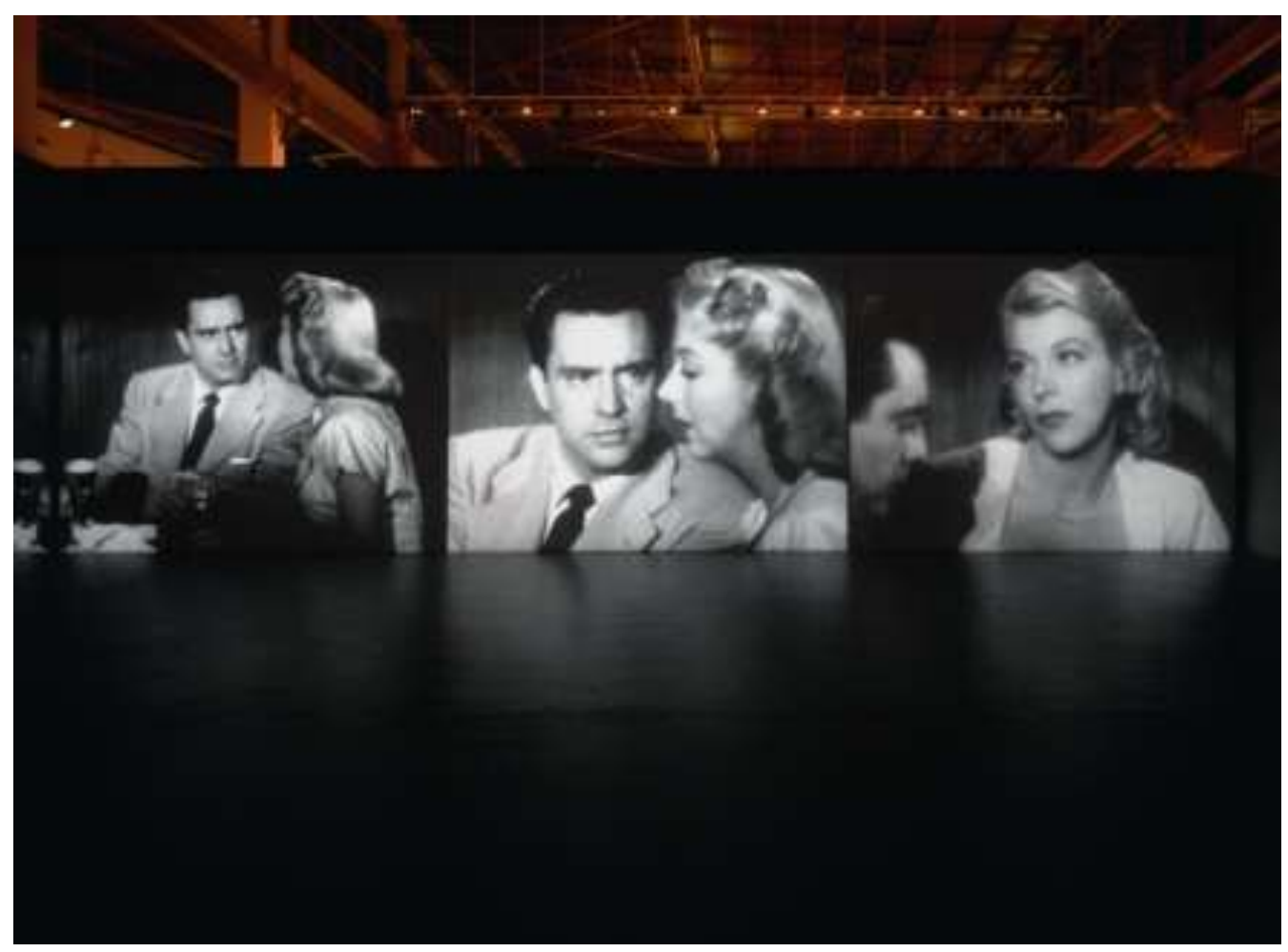

Figura 23: Douglas Gordon, Déjà-Vu. 2000.

Fonte: http://www.artishock.cl/2011/12/blockbuster-cine-para-exhibiciones/

A remontagem de fragmentos: artistas desta figura utilizam-se de fragmentos de vários filmes algumas vezes hollywoodianos, para mostrar como tais filmes repetem ações, repetem enquadramentos, movimentos de câmera etc. Os artistas também se apropriam de partes dos filmes e modificam a superfície das imagens, desgastando a película fisicamente. Temos aqui os exemplos: Pièce touchée (1989) de Martin Arnold, o qual retoma e manipula fragmentos do filme The Human Jungle (1954) de Jopeph M. Neuman e Outer Space (2000) de Peter Tscherkassky, que faz alterações e desgastes em partes retomadas da matéria fílmica da obra The Entity,(1982), de Sydney Furie,, filme fantástico americano que trata de possessão do corpo de uma mulher. 


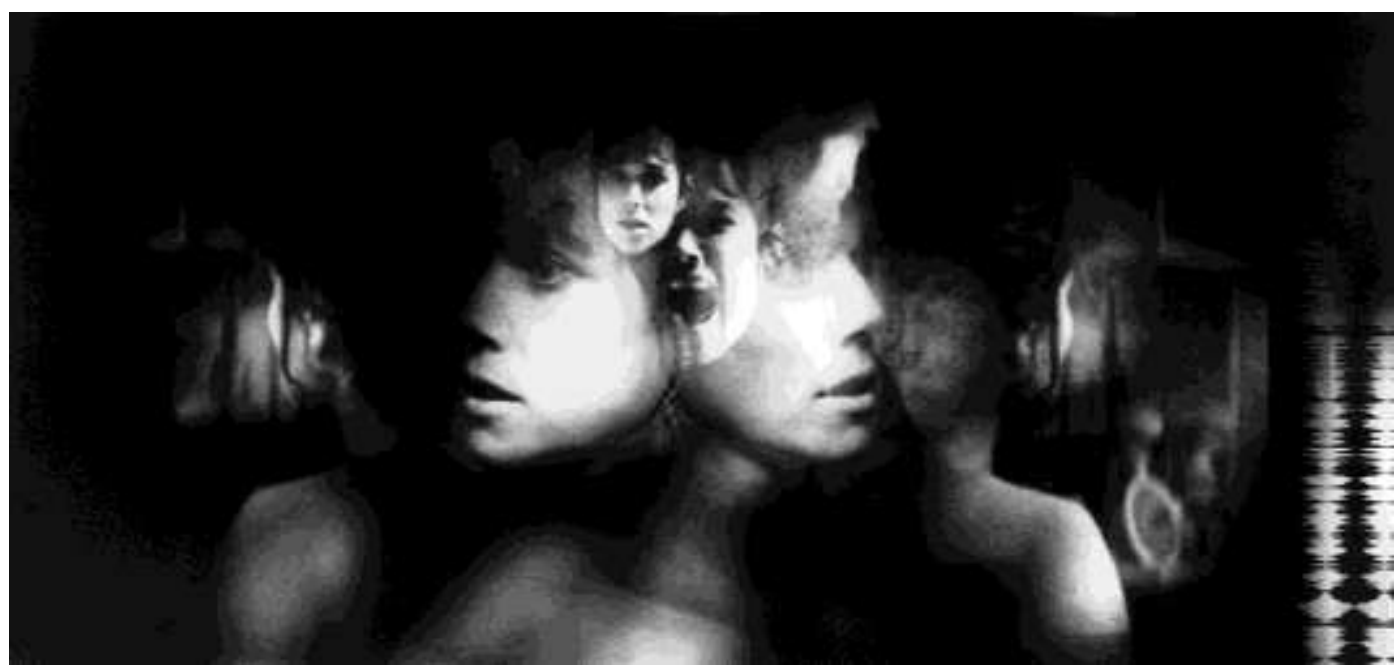

Figura 24: Peter Tscherkassky. Outer Space. 2000

Fonte: http://www.tscherkassky.at/content/films/theFilms/OuterSpaceEN.html

Filme reconstituído: os artistas reconstituem um filme, adicionam partes inexistentes do filme original, através de novas gravações, novos atores ou da retomada dos mesmos atores do original para refazer, por exemplo, uma elipse de uma parte do filme. É o que acontece em L'ellipse (1998), de Pierre Huyghe,, que refaz uma parte do filme, L'ami Américain (1977) de Wim Wenders. Apresentou a instalação em três telas, sendo que a do meio mostra a cena "faltante" com o mesmo ator do filme original. As outras duas telas mostram o filme de Wenders.

Filme materializado: nesta figura, os artistas questionam a fugacidade das imagens projetadas e sua "imaterialidade", apresentando o filme impresso e escolhendo, para isso, em alguns trabalhos apenas a impressão de uma imagem do filme ou o filme todo em síntese, reduzido a única imagem.

Para Peter Kubelka o cinema tem duas formas de ser mostrado e uma delas é pela projeção a qual o artista trabalha com certa intensidade pelo uso de "flicker", isto é, imagens piscando na tela, e a outra pela exposição do próprio filme pendurado na parede de uma galeria, o que Kubelka chama de "pinturas cinematográficas". O artista trabalha das duas maneiras, na vertente do cinema materialista como oposição ao efeito ilusionista do cinema tradicional. 
Outro artista que trabalha com a imagem do filme ampliada, selecionada, impressa e exposta é Éric Rondepierre que expõe a materialidade do filme, do suporte e mostra o efeito devastador do tempo, o desgaste sobre a matéria. Ele pesquisa filmes, em cinematecas, que estejam em mau estado de conservação e, quando observa uma imagem que tenha sofrido pelo tempo, pelos materiais químicos, uma alteração em sua composição, escolhe este quadro, refotografa, amplia e o expõe.

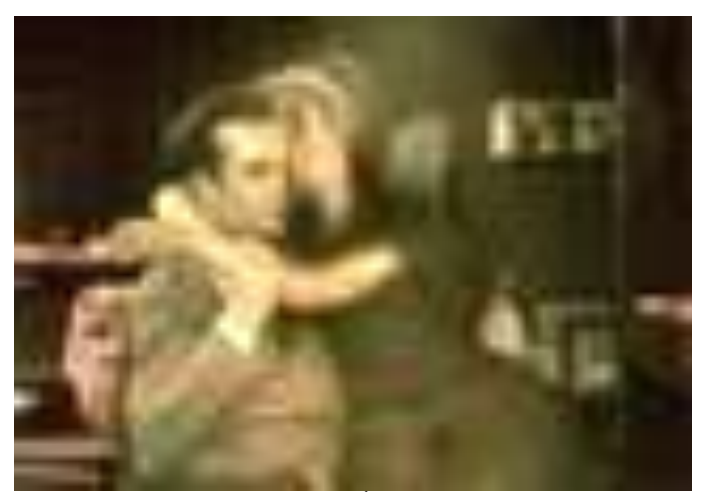

Figura 25: Éric Rondepierre. Les Trente Étreintes/ Os trinta abraços. 1997-1999 33

O segundo grupo de artistas, segundo Dubois, trabalha com a migração e usos do aparato do cinema: projeção, tela, arquitetura e narrativa, para os espaços diferenciados da sala tradicional.

Os trabalhos realizados pelos artistas do segundo grupo são divididos em quatro figuras. Na primeira estariam agrupadas a figura de projeção e a figura de tela; na segunda, montagem espacial; na terceira, a questão da narrativa e a trajetória do espectador, e por fim, identificação imersiva e arquitetura das imagens.

Figura de projeção: aqui se destacam os artistas que se apropriam parcialmente do dispositivo cinematográfico e, como os do primeiro grupo, cometem desvios nessa apropriação. Nesse sentido, temos Antony McCall que trabalha a projeção como elemento central de sua obra, como em Line Describing a Cone, de 1973. A obra é apresentada em uma sala escura, sem assentos para os espectadores. Nessa sala são ativadas máquinas de fumaça. A fumaça no espaço dá ênfase e volume ao cone de luz formado pela projeção. Os espectadores estão em movimento nessa sala, podem entrar, tocar o cone de luz.

\footnotetext{
33 Uma das 30 fotos que fazem parte da obra. Essa obra pode ser exibida de várias formas como por fotos avulsas ou as trinta fotos apresentadas em conjunto.

Fonte: http://www.ericrondepierre.com/pages/en_decomp_lestrente.html
} 


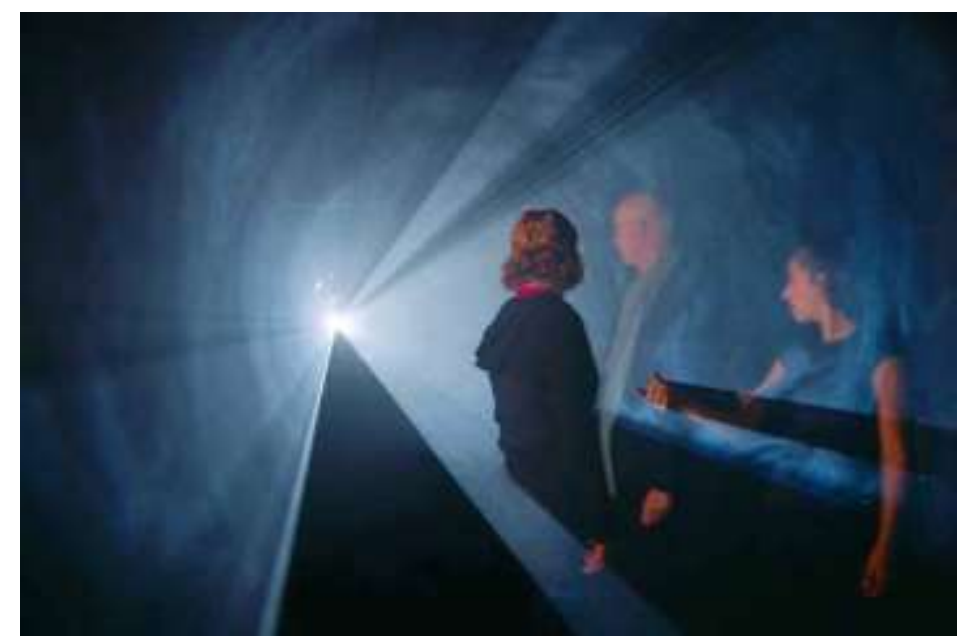

Figura 26: Antony McCall .Line Describing a Cone. 1973,

Fonte: http://www.tate.org.uk/art/artworks/mccall-line-describing-a-cone-t12031

Figura de tela: nesta figura o autor se refere a artistas que trabalham a tela diferentemente da tela tradicional de cinema, isto é, usam como suporte de projeção: objetos, árvores, armários etc., ou artistas que trabalham em suas obras a tela como elemento central, como Skyspace de James Turrell. Embora o artista nunca tenha escrito ou comentado sobre a ligação de seus trabalhos com o cinema, Dubois aponta a pura superfície do seu trabalho, como uma força de atração em nossa percepção, tal como a tela de cinema. Outro exemplo do autor, é a série de Hiroshi Sugimoto Theaters, que evoca diretamente a tela de cinema. São trabalhos fotográficos e cada foto apresenta os detalhes arquitetônicos e os assentos de salas luxuosas americanas dos anos 30 e 50; no centro da composição, a tela de cinema totalmente branca por excesso de exposição da fotografia, que de fato durou o filme todo.

Em continuidade do trabalho de Anthony McCall da projeção como "luz sólida", as obras de Turrell e Sugimoto prosperam a mesma ideia formal: o dispositivo tela como um espaço fenomenal de luz, tanto irradiado quanto absorvente, que apaga tudo o que traz à tona a "imagem". (DUBOIS, p.52, tradução nossa) ${ }^{34}$

$\mathrm{O}$ autor ainda exemplifica esta figura com telas invisíveis, como o trabalho de Melick Ohanian, Invisible Film (2005), no qual a artista projeta no deserto, um filme de Peter Watkins, Punishment Park, de 1971, que foi proibido de ser exibido, no Reino Unido e nos EUA por sua postura antiguerra após a ação militar no Vietnã. Devido à ausência de aparatos que serviriam de suporte para visualização, o filme não é visível. Traz também o exemplo de telas incompletas como um ventilador em movimento que é suporte de projeção para o

\footnotetext{
${ }^{34}$ DUBOIS, Philippe. Cinéma et art Contemporain: vers un Cinéma D'exposition?

De la migration d'un dispositif

ouvrage en préparation

(version de travail) versão gentilmente fornecida pelo autor durante palestra na ECA USP em 2013.
} 
trabalho de Alain Fleicher de 1980, Autant en emporte le Vent (E o Vento Levou).

Esta figura será adiante retomada por nós, seguindo e ampliando a reflexão do autor, através do estudo de obras mais extensas e se diferenciem no uso do material, duração da tela do cinema tradicional.

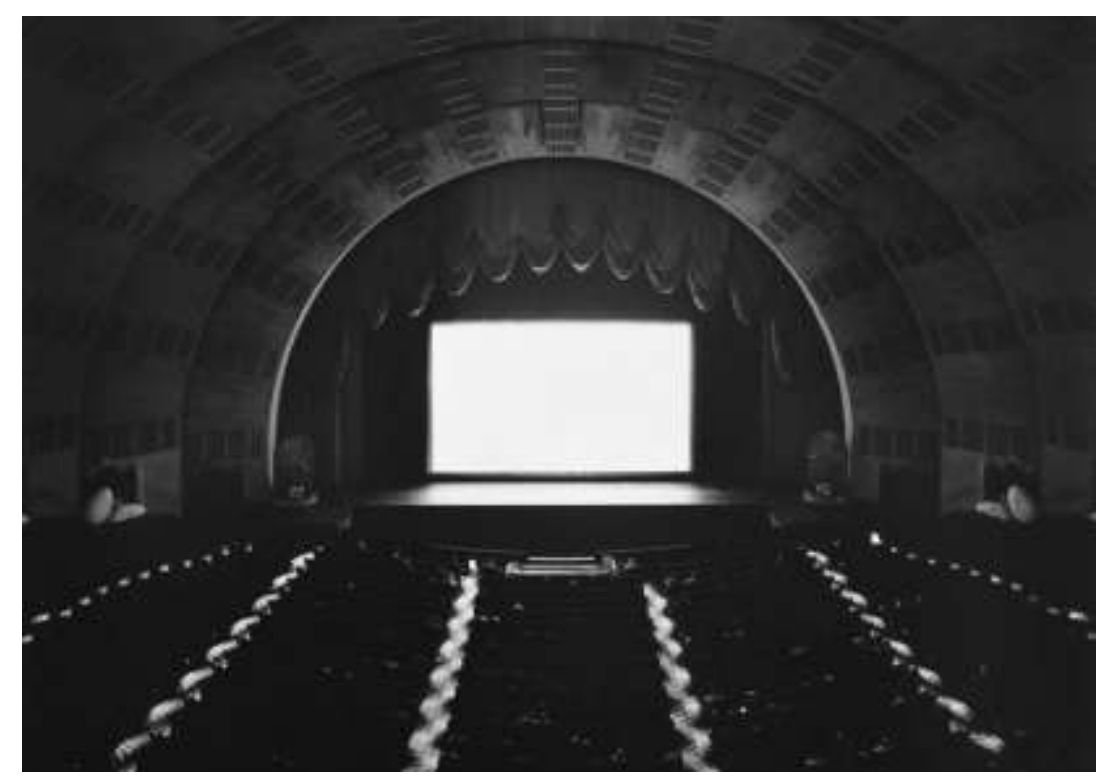

Figura 27: Hiroshi Sugimoto. Radio City Music Hall. 1978

Fonte: http://lookseedo.org/2011/10/02/strange-shapes-eerie-lights-and-figures-on-display-meet-hiroshisugimoto-born-1948/

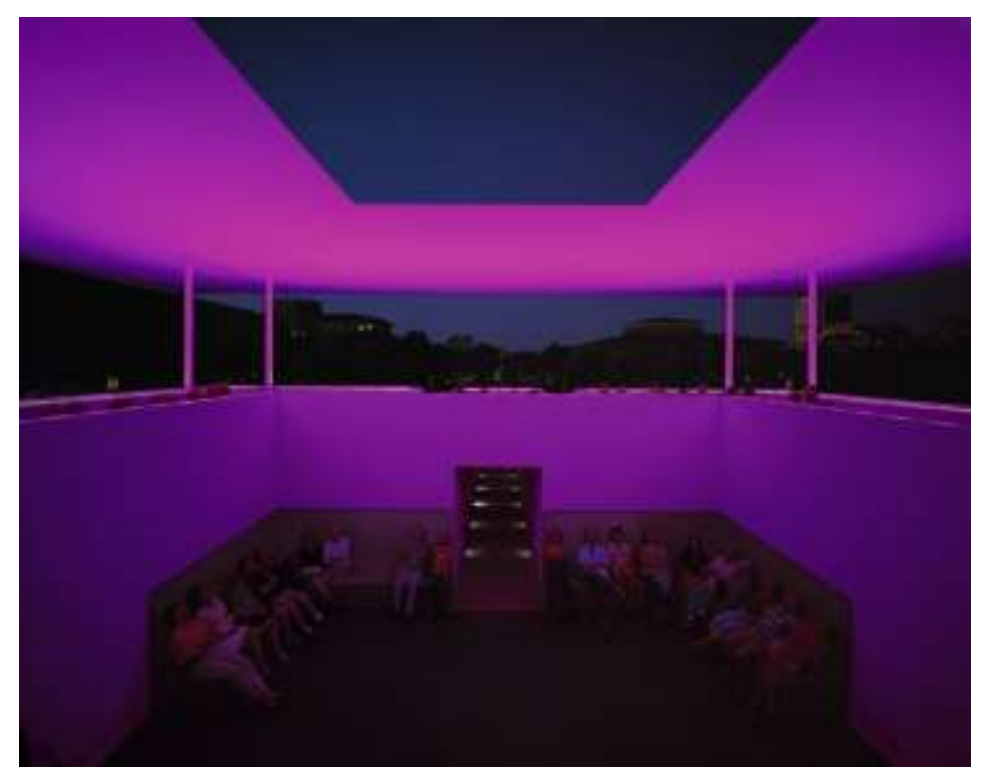

Figura 28: James Turrell. Skyspace. 2012

Fonte: http://jamesturrell.com/artwork/twilightepiphany 
Montagem espacial ou a questão das multitelas: estariam aqui os artistas que espacializam as telas e trabalham também o espaço da exposição como um equivalente espacial das formas fílmicas temporais comuns ao cinema como: campo/contracampo, elipse, montagem alternada, paralela etc, aplicadas para uma disposição espacial nos locais expositivos. O campo e o contracampo além de sua tradicional apresentação temporal, serão também dispostos espacialmente por telas posicionadas uma de frente para a outra ou lado a lado numa projeção simultânea.

A questão da narrativa e a trajetória do espectador: nesta estariam os artistas que trabalham e se preocupam em contar histórias dentro de uma exposição da qual o percurso do observador pelo espaço expositivo é o que gera a leitura do trabalho.

Identificação imersiva e arquitetura imagens: nesta os artistas exploram o espaço além da sala escura, que foi um desdobramento da câmera escura, e alguns artistas ao invés de trabalhar nela ampliam os espaços de imagens com, por exemplo, o uso da cidade como tela.

Dentro desse panorama do pensamento de Dubois da relação entre arte contemporânea, cinema e seus desdobramentos, iremos agora traçar algumas reflexões que fizemos baseadas nos conceitos, e leituras do teórico, focando e usando alguns dos exemplos dados em sua figura de tela. Pretendemos ampliar esta reflexão a partir da observação e tentativa de mapear as superfícies de projeção que os artistas contemporaneamente se utilizam e que desviam do padrão da tela de cinema tradicional.

Entendemos que é a relação do todo que regula a experiência com o espectador, isto é, a superfície de projeção, as imagens, onde estas imagens estão inseridas, como são apresentadas, a projeção, o espaço etc. Entretanto, neste estudo, como ressaltado em todo o texto, focamos a tela ,ou superfície de apresentação das imagens, que por si só compõe um dos dispositivos que regulam nosso relacionamento com as obras, sendo seu material, formato, duração, quantidade, mobilidade, importantes nesse relacionamento.

Observamos tanto na contemporaneidade como nos primórdios das artes visuais e do cinema que o suporte, o material, o formato desse suporte, fazem parte do procedimento, da poética da obra.

Podemos observar a importância do suporte já nas pinturas das cavernas, pelo uso e aproveitamento estético das texturas, irregularidades encontradas nelas que contribuem segundo Watchel (1993) para o que ele chama de experiência cinematográfica que é dada, segundo ele, pela forma e procedimentos usados na produção dos desenhos, superfície utilizada e modo de visualização das imagens. 
É a junção das sobreposições de imagens, (adição de partes, extrapartes de membros nos animais que não existem na realidade (ex: duas cabeças para um único animal), adicionadas ao suporte irregular das paredes das cavernas e mais o direcionamento irregular da iluminação das lanternas (provocado pelos gestos dos "espectadores" que revelam ou escondem partes da pintura), que vão criar a impressão de movimento.

Segundo o autor os artistas do Paleolítico faziam cinema e cinema underground e, ainda no seu entender, "artistas do Paleolítico tinham as ferramentas de um pintor, mas os olhos e mente de um cineasta." (WATCHEL, 1993, p.140). Aqui, podemos observar uma das relações mais antigas entre artes viisuais e cinema.

O estudo de Watchel nos é imprescindível por enfatizar, além de outros procedimentos, a superfície, os suportes em que foram feitas essas pinturas (paredes irregulares das cavernas) daí o defendermos como de fundamental importância na leitura e percepção destas imagens. A importância da superfície será aqui observada, mapeada e esboçada em vários trabalhos, como na série de nossa autoria Autorretrato com duração e sons variáveis (2011-2014) e também em nossa videoinstalação Pintura em Atos (2012), (as duas obras serão abordadas no capítulo 3 nos tópicos 3.4 .2 e 3.4.5). Ambas trabalham plasticamente a superfície de exibição das imagens. Posteriormente, no capítulo 3 analisaremos e aprofundaremos nessas e em outras obras que usam características das superfícies de projeção para gerar mudanças no aspecto formal e escolhas simbólicas de material das obras exibidas.

Temos também a utilização de projeção de imagens sobre fumaça, espelhos (como vimos no capítulo 2) nas fantasmagorias, principalmente de Etienne Gaspard Robert. Segundo Barbosa, o artista:

Projetava imagens de aspectos recentes da Revolução Francesa, [...] buscando uma exploração que extrapolasse a mera projeção dos seus slides, ele mascarava as bordas das imagens com tinta preta, suprimindo o círculo de luz branca que normalmente envolvia as imagens projetadas, dando uma aparência de flutuarem livremente. Como se não bastasse, as superfícies nas quais incidiam as imagens eram também preparadas para aumentar o efeito, de modo que projetava sobre espelhos, vidros, através de fumaça e sobre telas de gaze embebidas em parafina translúcida ( BARBOSA, 2001, p.32).

No cinema tradicional, as imagens de fotogramas estão na máquina de projeção. São ampliadas e transportadas para a tela, que se comporta como um espelho e reflete as imagens transportadas aos olhos dos espectadores a uma velocidade regular que gera a ilusão de movimento.

Observamos que a tela cinematográfica neste cinema não é vista apesar de seu majestoso tamanho como um elemento importante, ou seja, o que importa mais é o que ela 
reflete: as imagens, a construção pela qual passaram para gerar relações espaçotemporais e assim obter uma narrativa. A tela também é uma superfície usada para o desfile de vários filmes que projetam imagens que passam sobre ela e esvaecem.

Para este estudo, as propriedades como: cor, material, durabilidade, fisicalidade em geral das tela/objetos de projeção nos interessam, pois não são superfícies apenas para refletir as imagens projetadas (sendo transparentes); elas podem ter efeito estético intenso quando trabalhadas na poética artística. Os artistas cujas obras observaremos trabalham a relação projeção e suporte de imagem, relação que possibilita identificarmos novas características que não estavam nas imagens gravadas. Essas características aparecem apenas nas performances dos aparelhos e dos materiais utilizados.

Nesta pesquisa criamos uma classificação das telas para melhor compreensão do estudo das superfícies de projeção (telas), sem intenção de apresentar um estudo taxativo e nem de encerrar as possibilidades de outras leituras. O objetivo é classificar as telas pelas suas propriedades mais ressaltadas. A observação foi se desenvolvendo durante a construção de obras de nossa autoria, após as leituras de Dubois principalmente na sua figura de tela, da qual retomamos alguns exemplos e de alguns trabalhos de artistas em que a tela é específica para determinada obra, isto é, ela nem sempre é um desfile evanescente de imagens, nem sempre é feita do mesmo material, nem sempre pode servir a outro filme, pode ser efêmera, pode ser tridimensional de acordo com a poética do artista.

Classificação das telas:

Telas que registram: estas telas não mostram a evanescência das imagens como no cinema tradicional; são telas preparadas num processo semelhante ao de um pintor. Como exemplo, temos o trabalho de Alain Fleischer em Tela sensível (2003). Neste caso, a tela é preparada pela adição de folhas químicas que registram (no decorrer do tempo e durante a projeção pelas suas propriedades fotossensíveis) um filme que tradicionalmente seria visto como uma série de imagens evanescentes. Este trabalho foi exposto no Centro Cultural do Banco do Brasil do Rio de Janeiro em 19 de maio de 2003. Realizada em uma sala que tem uma luz vermelha de segurança como guia, nesta obra a tela tradicional de cinema é recoberta por folhas de papel fotossensível e nela um filme é projetado como de costume em uma sessão normal de cinema. Os espectadores sentam-se, as luzes se apagam e a projeção é iniciada. Terminada a projeção, as pessoas devem permanecer no local e assim inicia-se a visualização do trabalho. A sala onde a projeção foi realizada recebe assistentes da obra, com baldes e escovões, que começam a passar revelador na tela, à qual foi adicionado papel 
fotográfico anteriormente ao início da projeção. Após os gestos (pinceladas com as químicas de revelação fotográfica) dos assistentes as imagens começam a serem reveladas para os espectadores, aparecendo sobrepostas, fugidias, e um acúmulo de tempo sobreposto é apresentado no espaço da tela. A tela é dotada de memória.

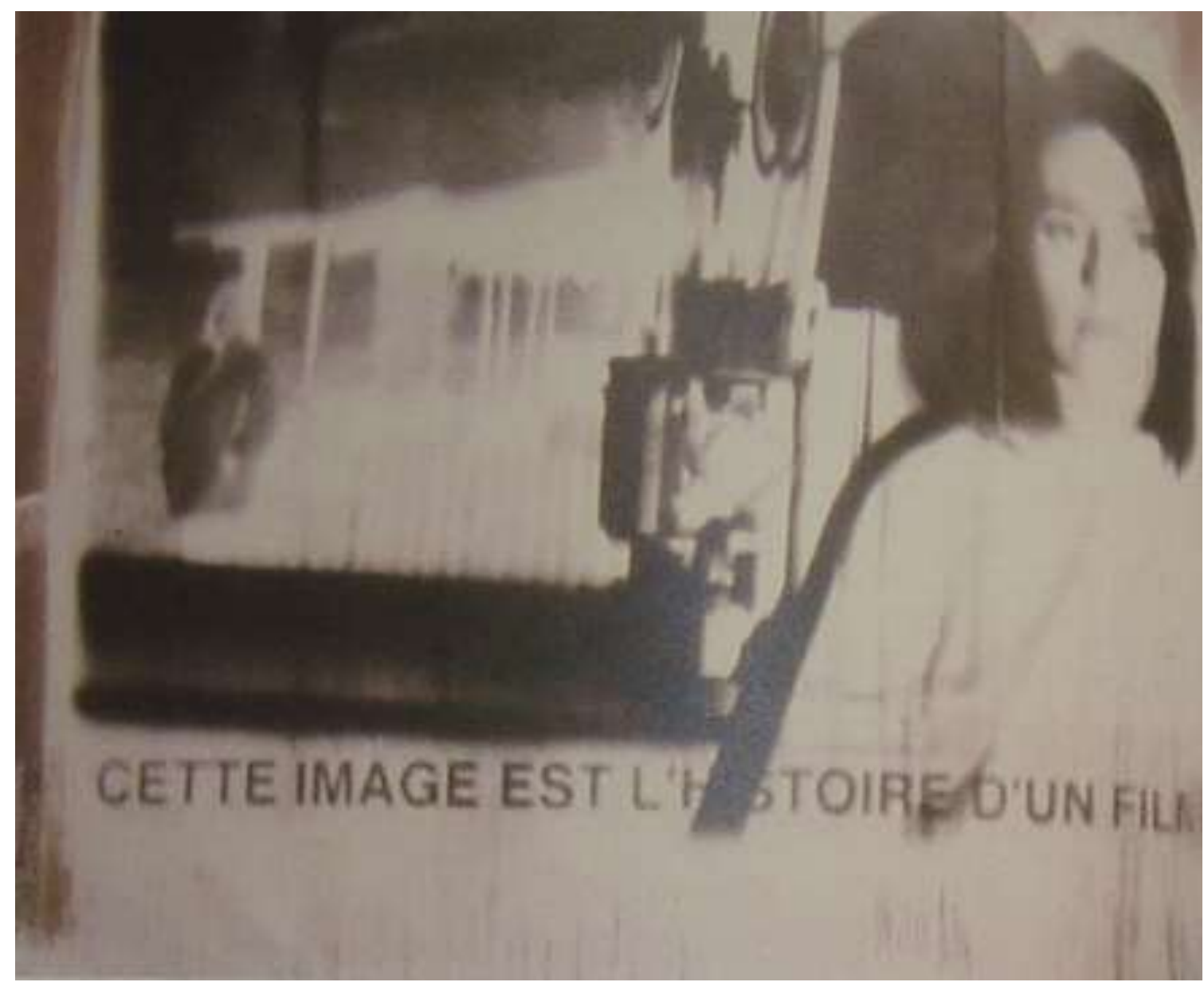

Figura 29: Alain Fleisher. Tela Sensível. 2003

Telas temporais: Aqui temos as telas que aparecem e desaparecem de forma cronometrada. A tela de cinema tradicional apresenta-se disponível no espaço de apresentação e não muda de forma ou de tamanho, tendo como função na maioria das vezes a apresentação de uma imagem nítida, e serve para diversos filmes. O trabalho de Rosângela Rennó, Experiência de Cinema (2004/5), é uma obra que utiliza o tempo como regulador do aparecimento e desaparecimento do suporte (tela de fumaça) e da projeção das imagens fotográficas. Ele é dado na relação disparo da projeção fotográfica simultaneamente ao comando de aparecimento do suporte tela de gelo seco. O espectador entra em uma sala escura, onde a visibilidade das imagens é relativa. A cortina de fumaça deforma, altera e dá 
movimento às imagens projetadas que são estáticas. Desta forma, o suporte é importante na qualidade e visibilidade parcial das imagens, pois é através dele que a imagem sofre alterações, continua sendo modificada durante a exibição e gerando novas características, que não estavam no registro da imagem. Nos trabalhos com suportes convencionais as imagens embora ampliadas e serem luminosas, não são pensadas para sofrer modificações em sua constituição. Nesta obra a modificação das imagens devido ao desaparecimento da imagem e do suporte participa da poética da artista.

Ela faz uma homenagem aos mecanismos de projeção das lanternas mágicas, remetendo às primeiras experiências do cinema. As imagens que são projetadas compõem quatro programas: filme policial, filme de guerra, filme de amor e filme de família. Embora este trabalho, como os outros que relacionamos, possa estar em mais de uma classificação, nós o inserimos nas telas temporais, porque achamos mais pertinente. Posteriormente, neste capítulo, na parte das análises das obras, o retomaremos.

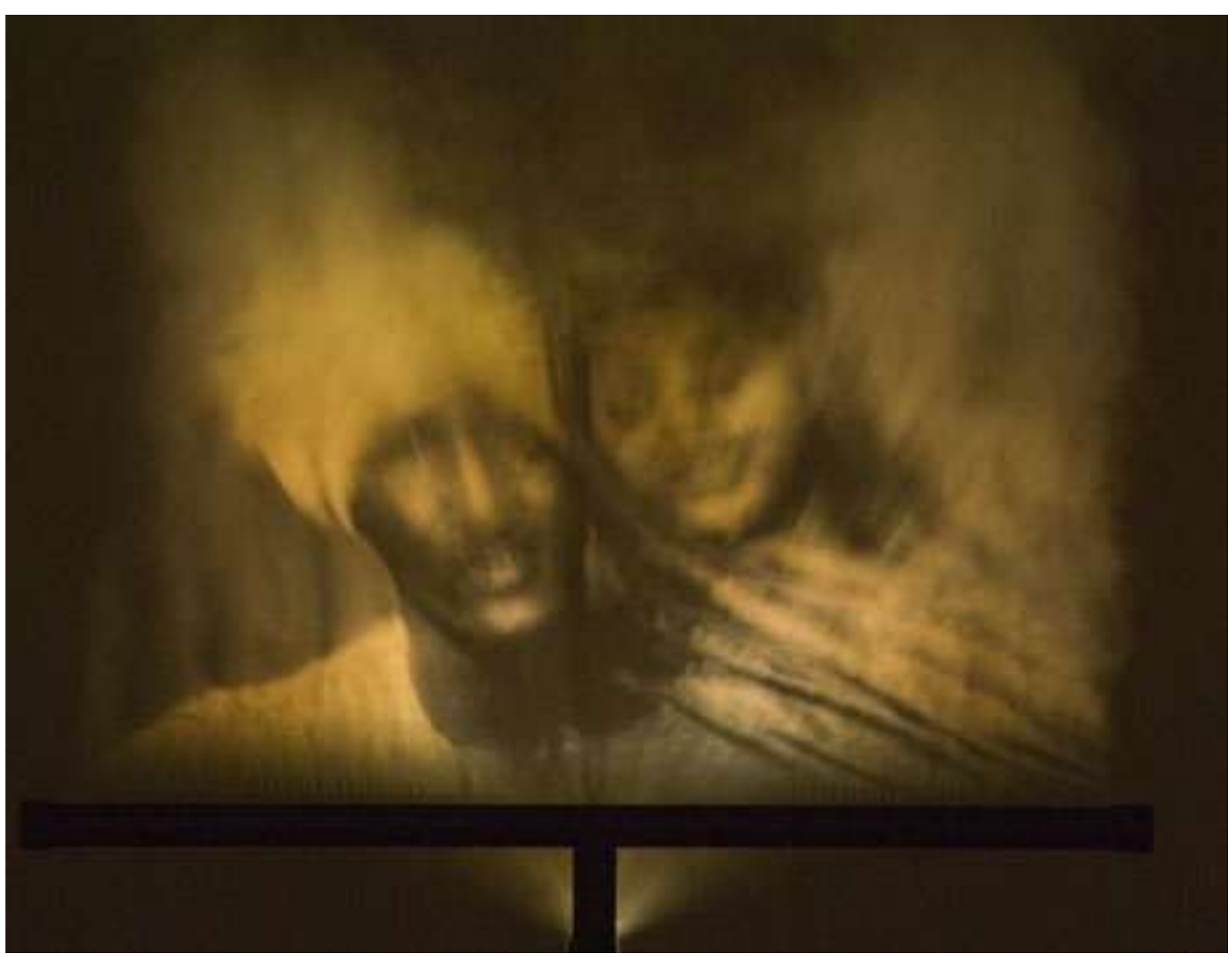

Figura 30: Rosângela Rennó. Experiência de Cinema. 2004-5.

Fonte: http://curatorsintl.org/exhibitions/phantasmagoria_specters_of_absence 
“Telas" cinéticas: Aqui temos como exemplo a obra de Alain Fleisher de 1980 Autant en Emporte le Vent (E o Vento Levou). Instalação cinematográfica, com projeção em looping, de um filme de $16 \mathrm{~mm}$ sobre as palhetas de um ventilador em funcionamento - criando uma espécie de efeito estroboscópio artesanal. A imagem de um rosto com cabelos esvoaçantes é visualizada sobre um ventilador em movimento. Nesta obra tanto a película quanto o ventilador (suporte de exibição da imagem) estão em movimento. Trata-se de uma tela parcial que gera através do movimento e da percepção dos espectadores a ilusão de figura completa.

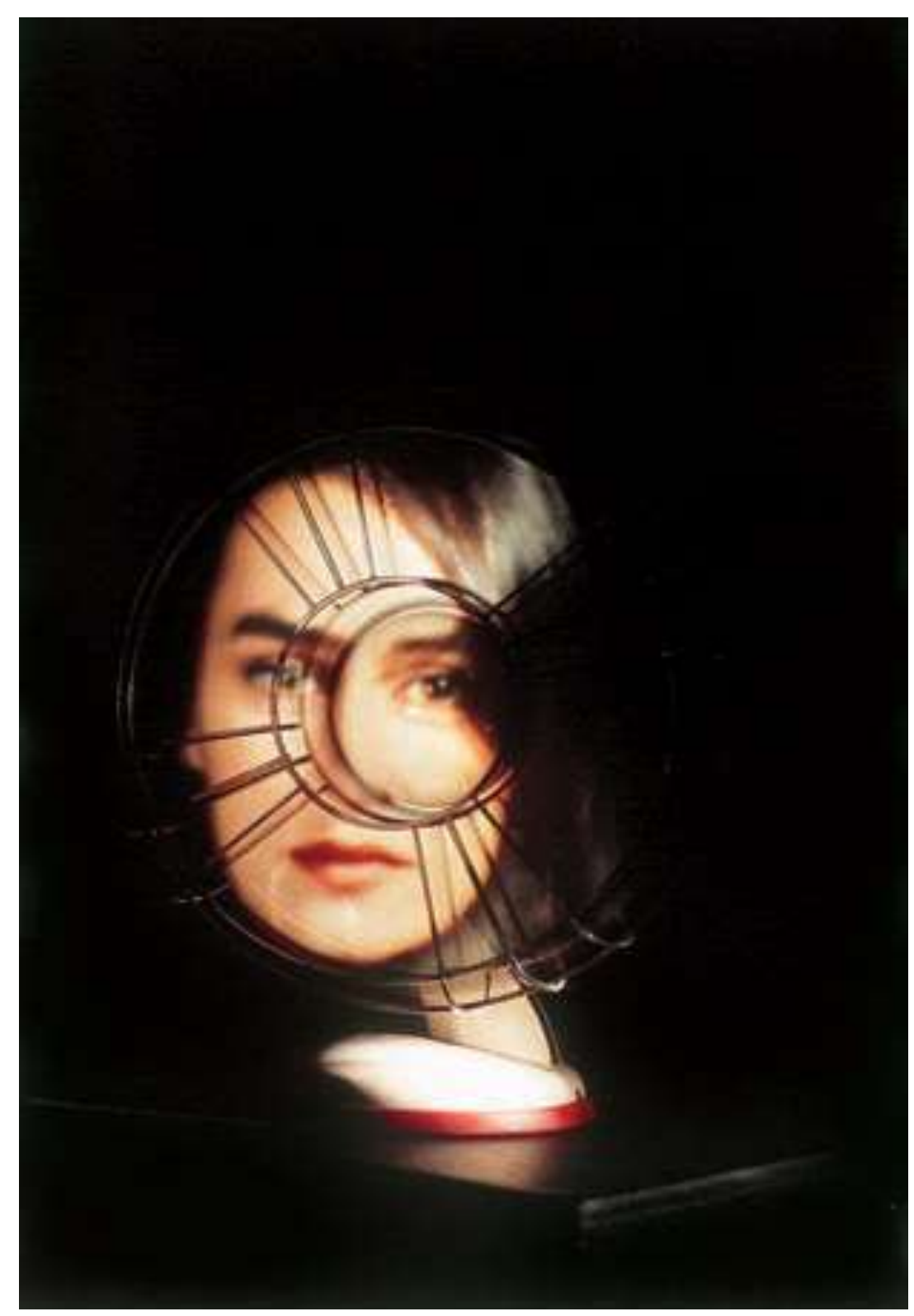

Figura 31: Alain Fleisher. Autant en Emporte le Vent (E o Vento Levou), 1980 Fonte: http://media.artabsolument.com/pdf/article/22807.pdf 
Tela efêmera: Exemplo deste tipo de tela se encontra na série de nossa autoria intitulada Autorretrato com duração e sons variáveis, que está em seu número IV. Essa série está sendo realizada até o momento com projeção de autorretratos em telas de gelo. Realizamos uma performance diante da câmera fixa, posteriormente projetamos o vídeo desta performance sobre telas de gelo (água e tinta congelada). A cada apresentação as telas têm durações variáveis e geram em sua relação com o recipiente colocado abaixo delas, sons variáveis. Diferenciam-se assim do cinema tradicional que tem duração específica. Este trabalho será retomado com mais detalhes neste capítulo no tópico 3.4.2

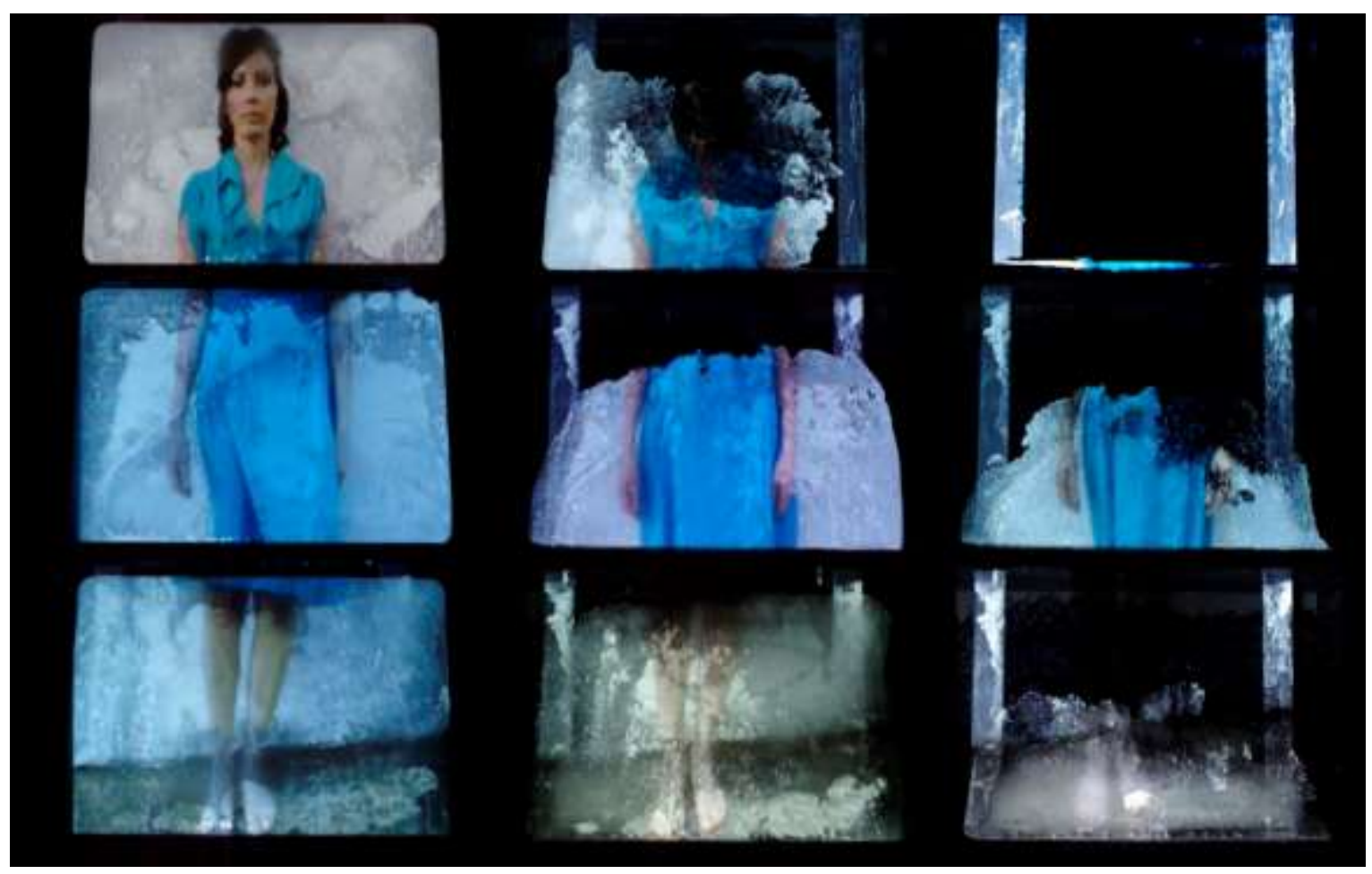

Figura 32: Viviane Vallades. Autorretrato com duração e sons variáveis III. 2012

Tela intangível: Temos como exemplo o trabalho de Melick Ohanian, Invisible Film (2005), onde a artista projeta um filme de Peter Watkins, Punishment Park de 1971, que foi proibido de ser exibido, no Reino Unido e nos EUA, por sua postura antiguerra após a ação militar no Vietnã, como já dissemos. O filme mostra uma espécie de "caça aos rebeldes", realizado no deserto da Califórnia por parte da polícia e do exército e termina em um 
massacre organizado. É projetado por Melick em El Mirage Dry Lake, na Califórnia. Embora efetivamente rodando no projetor, não é visível, não há anteparo próximo que faça a reflexão para os espectadores.

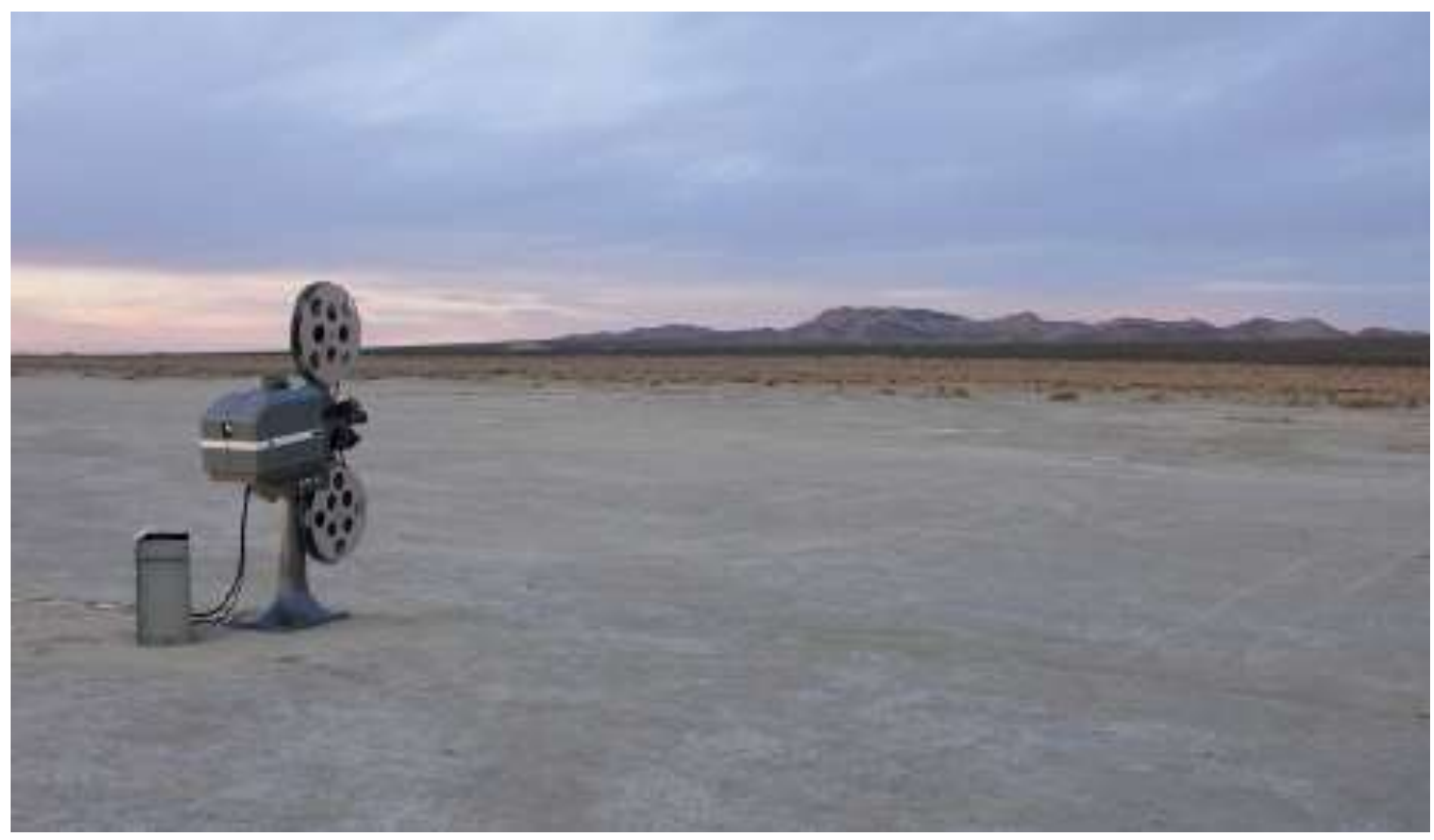

Figura 33: Melick Ohanian, Invisible Film.2005

Fonte: http://www.apengine.org/wp-content/uploads/2010/04/fact-image.jpg

Telas em camadas: Aqui temos como exemplo o trabalho de Bill Viola The Veiling, (1995). Trata-se de uma das cinco instalações de vídeo e som que Bill Viola criou para ocupar as cinco salas do Pavilhão dos Estados Unidos durante a $46^{\mathrm{a}}$ Bienal de Veneza, em 1995. Nela o artista usa nove telas de tecidos translúcidos em camadas e suspensas como suporte para a dupla e oposta projeção de dois vídeos. Em um dos lados de uma sala escura o artista projeta um vídeo de um homem e do lado oposto da sala projeta um vídeo de uma mulher. Ambos estão se movendo. Eles se afastam e se aproximam da câmera e estão em uma paisagem noturna. $\mathrm{O}$ encontro do homem e da mulher se dá em alguns momentos na tela central, e esse encontro só acontece pela luz, pois nos vídeos o homem e mulher estão separados. O uso de luz projetada a partir de duas direções sobre tecidos translúcidos que difundem a luz gera a impressão de imagens em movimento um em direção ao outro. 


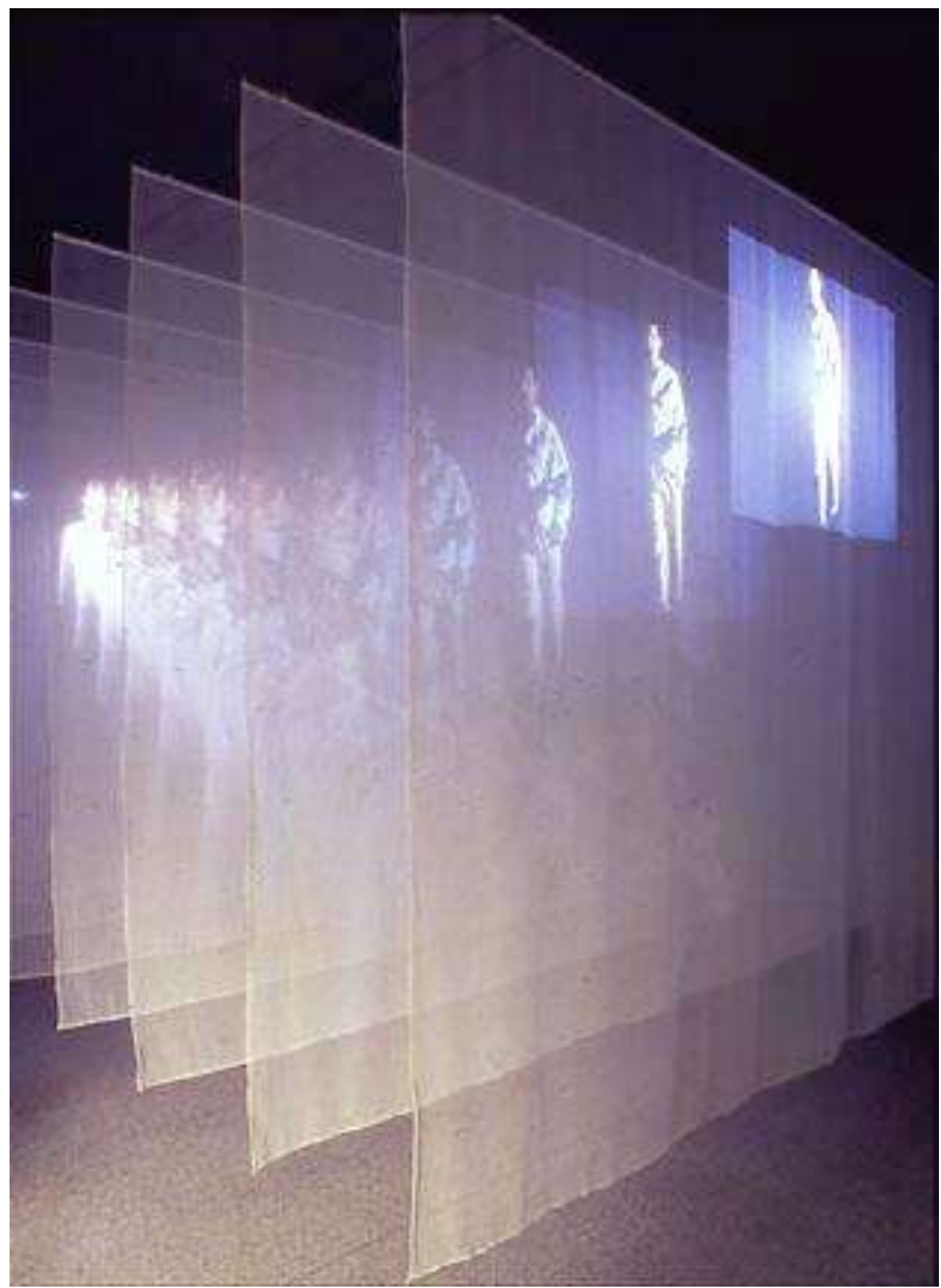

Figura 34: Bill Viola. The Veiling. 1995

Fonte: http://asuartmuseum.asu.edu/1996/viola/vieling.php 


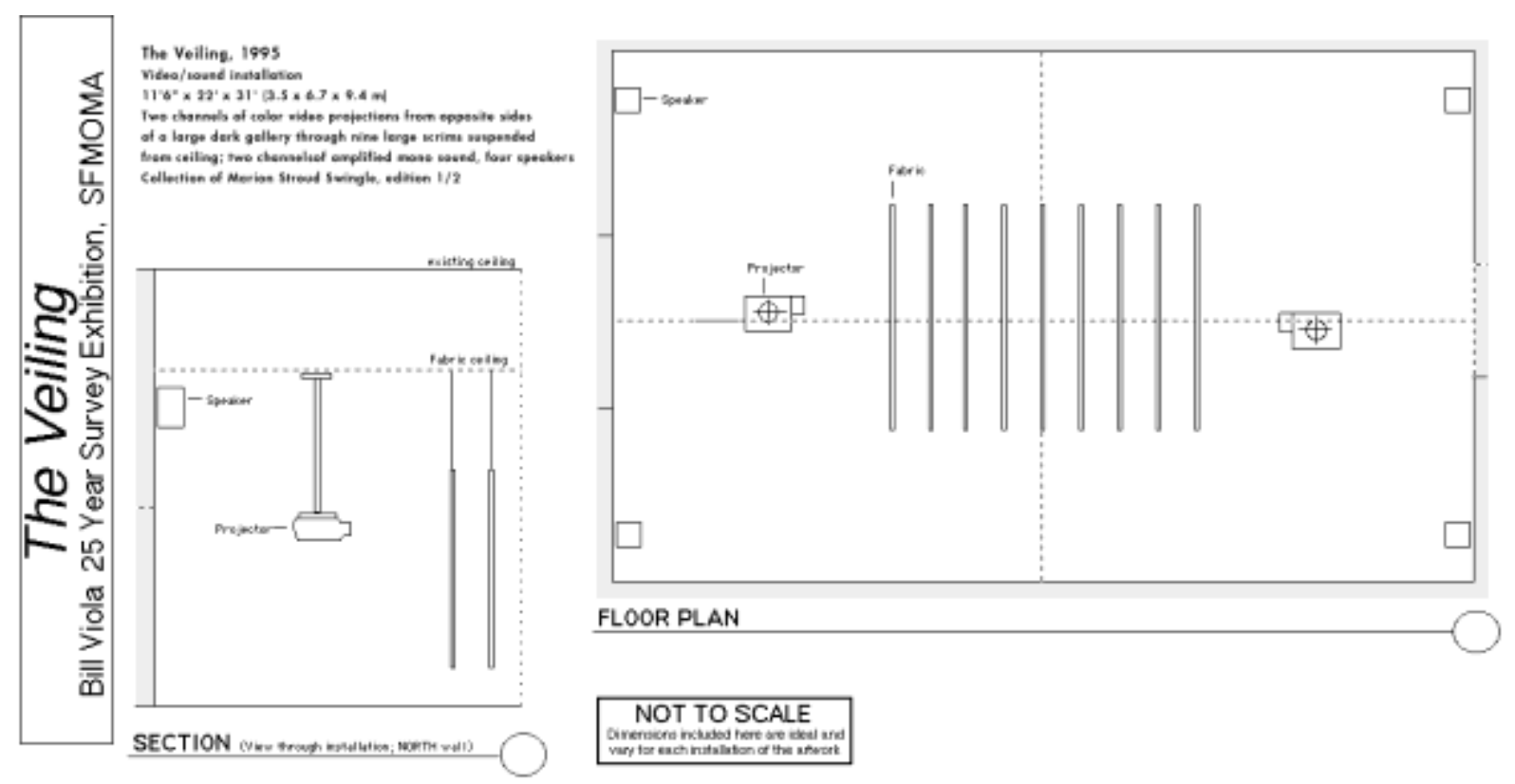

Figura 35: Bill Viola. The Veiling. 1995

Esboço de montagem

Fonte: http://www.sfmoma.org/media/features/viola/BV14_tech.html

Telas perfuradas: São telas que, por formas geométricas ou irregulares vazadas, deixam a luz atravessar o suporte e assim ser observada em camadas. Temos como exemplo o trabalho de nossa autoria intitulado Pintura em atos (2012). Nesta obra a projeção é feita sobre folha de Eucatex perfurada e a projeção é feita em camadas, através da continuação da luz até o próximo anteparo (quase sempre uma parede branca). Em Pintura em Atos, realizamos pinturas (de uma forma inusitada) em nosso corpo e as registramos em vídeo. Expomos o processo de construção da obra, utilizamos nosso corpo como suporte para a pintura e através da construção de dispositivos e sua relação criada com o espaço apresentamos o vídeo da pintura em camadas. A obra requer a percepção, o deslocamento do espectador para sua leitura.

O vídeo é produzido em quatro janelas simultaneamente. Entramos em cena, no quadro do vídeo, realizamos a pintura e saímos de quadro. No vídeo, há sons ambientes e sons de água caindo quando jogamos tinta em nosso corpo. Este trabalho será abordado novamente, neste capítulo no tópico 3.4.5. 


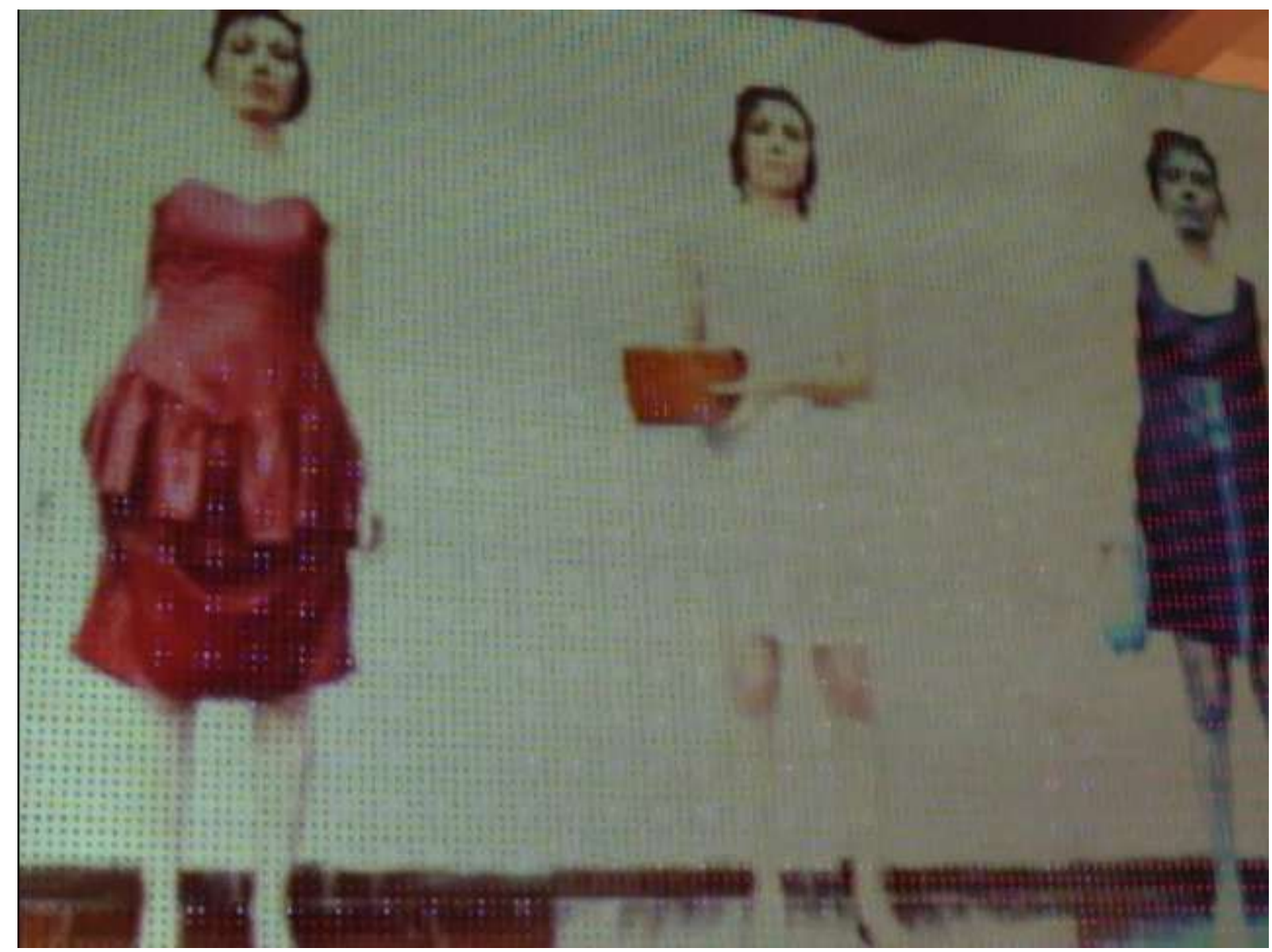

Figura 36: Viviane Vallades. Pintura em atos. 2012

Telas simbólicas: Aqui temos como exemplo Krzysztof Wodiczko, artista que trabalha primeiramente com projeção de slides e posteriormente com projeção de vídeos em monumentos e fachadas.

Embora seu trabalho não esteja inserido em galerias e museus, nós consideramos sua apropriação de monumentos e fachadas como telas, pertinentes ao nosso estudo. $\mathrm{O}$ artista mostra pela projeção de imagens e sons amplificados: vozes, imagens, memórias esquecidas, abandonadas de pessoas que estão à margem da sociedade e do lugar onde vivem. Na maioria dos trabalhos essas vozes e imagens (ativadas quando projetadas e expostas em monumentos) são de imigrantes.

O artista faz uma relação com a história do local escolhido e as imagens que projeta, com o intuito de modificar as estruturas fixas da sociedade e contribuir a construção de uma nova história.

Pretende atualizar, expandir a história que ficou limitada à dos vencedores, isto é, aquela que está nos livros e que esta preservada. 
A história preserva, seleciona eventos e apaga outros, e o artista, tenta criar mecanismos para modificação dessa história fixa e seletiva, para isso oferece por aparelhos de projeção e de amplificação de som a voz e a visibilidade aos "vencidos", ou seja, aqueles que não tem espaço na história oficial e que frequentemente são excluídos dos discursos públicos.

Wodiczko propõe mecanismos de projeção de imagens de mãos, rostos, gestos e fala ampliada de pessoas, pelo espaço, para que todos do local conheçam suas histórias e as compartilhem com muitos da cidade. Através da repercussão da mídia que registra o trabalho do artista nos espaços urbanos, as falas e imagens podem ser vistas e ouvidas por muitos através da TV, internet etc.

Nós classificamos seu trabalho como telas simbólicas, já que o artista escolhe locais que são símbolos de memórias, acontecimentos históricos e os ativa. Cria condições para que as novas gerações possam lidar com o que aconteceu, com o que está acontecendo e tentem evitar que fatos trágicos sejam repetidos.

Como exemplo, temos seu trabalho Hiroshima Projection (1999), onde o artista propõe uma projeção para acontecer na noite do aniversário do bombardeio (6 de agosto), em uma das poucas estruturas que restaram desse bombardeio, o Memorial da Paz de Hiroshima (Genbaku Dome), em Hiroshima, Japão, que é um símbolo da realização da paz mundial e memorial das vítimas da tragédia. $\mathrm{O}$ artista pelas suas estratégias atualiza, reanima o monumento com vozes e pela projeção de gestos de pessoas que viveram direta ou indiretamente a experiência da bomba. Dando espaço para a fala de japoneses e também de coreanos que foram tratados na época do bombardeio como vítimas de segunda ou terceira categoria, essas projeções ocorreram na base do prédio às margens do rio Motoyasu.

$\mathrm{O}$ rio é uma testemunha tanto como o edifício A-Bomb Dome refletida na água. Foi, de facto, o rio que se transformou num cemitério para as pessoas e edifícios. O rio foi onde as pessoas saltaram para a morte, porque eles achavam que iria ajudá-las a esfriar suas queimaduras, mas na verdade ele apenas contribuiu para uma morte mais rápida. Esses são os eventos ou cenas lembradas por alguns dos participantes durante a projeção no memorial e artistas que estavam falando através do edifício, como se estivessem no prédio, olhando para o rio e vendo tudo isso de novo, as pessoas saltando. Ao mesmo tempo, o rio continua o seu fluxo, como se nada tivesse ocorrido. Existe água fresca chegando. O rio é como um trágico testemunho, mas também a esperança, porque ele está se movendo. (WODICZKO, 2005tradução da autora $)^{35}$

\footnotetext{
${ }^{35}$,WODICZKO,Krzysztof,: Entrevistado por ART21. Krzysztof Wodiczko: "Hiroshima Projection" http://www.art21.org/texts/krzysztof-wodiczko/interview-krzysztof-wodiczko-hiroshimaprojection, .acessado em 30/06/2013
} 

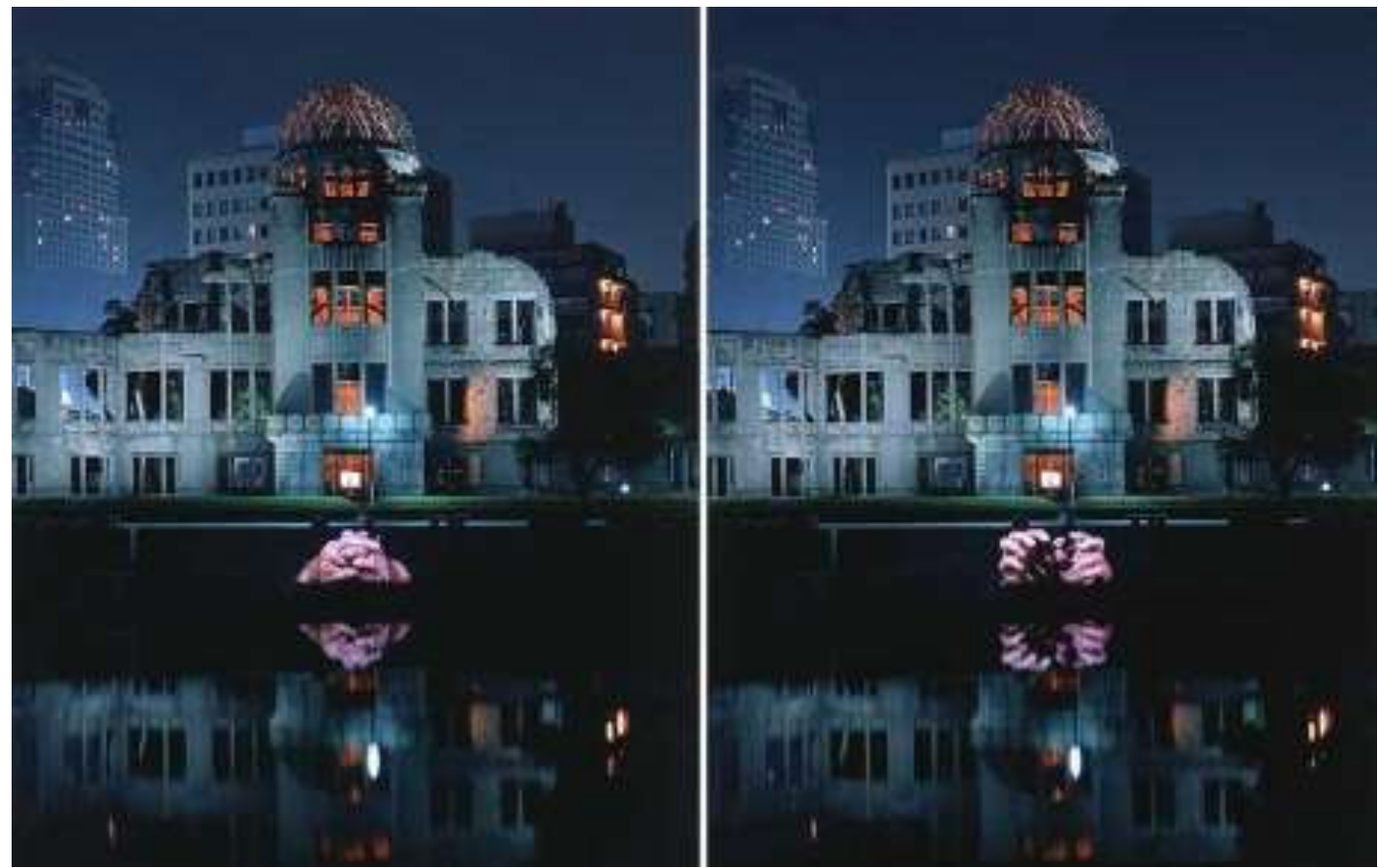

Figura 37: Krzysztof Wodiczko Hiroshima Projection. 1999

Fonte: http://www.pbs.org/art21/images/krzysztof-wodiczko/the-hiroshima-projection-1999

Telas interativas: na história da arte temos as telas estáticas tradicionais da pintura, a tela do cinema, e mais recentemente as telas interativas. As telas interativas são telas pensadas para responderem a interação do espectador e possibilitam modificações através da relação homem e máquina .

As instalações interativas oferecem interfaces de acesso ao público e, através de sensoriamento, ou por dispositivos de captura como teclados, mouses, telas sensíveis permitem a ação do público com respostas em tempo real por parte das máquinas. $(\text { DOMINGUES })^{36}$.

O espectador pode modificar as imagens, o que está sendo apresentado, através de toques no mouse, movimentos corporais, ações físicas etc. Esses gestos, toques, acionamento de comandos possibilitam ao espectador brecar, acelerar, fundir, modificar o fluxo de imagens. Aqui nos limitaremos às telas sensíveis ao toque, aquelas em que a própria tela é a interface física entre homem e máquina e que gera as modificações a partir disso.

As telas tradicionalmente foram feitas e pensadas para serem contempladas. Em exposições estão apresentadas e limitadas por faixas de segurança com avisos de "não toque",

\footnotetext{
${ }^{36}$ DOMINGUES, Diana. As instalações multimídia como espaços de dados em sinestesia. Relações corpo/arquitetura/ memória e tecnologias.

http://www.iar.unicamp.br/disciplinas/ap858/AXILA/pagdianadomingues.html acessado dia 30/06/2013
} 
“não ultrapassem este limite.” Nessas obras interativas o aviso é modificado para: “toquem na obra!".

O Trabalho que escolhemos é um dos diversos exemplos que poderiam estar descritos aqui.

Body maps de Thecla Schiphorst é uma obra composta por uma "tela" sensível ao toque e proximidades dos visitantes. É constituída de uma projeção de cima em videodisk do corpo da artista, (juntamente com um corpo digitalmente representado) em uma mesa disposta na horizontal e inserida num espaço escuro. A superfície da mesa é coberta de tecido aveludado, drapeado que atrai, que se oferece, ao toque do espectador. A pressão exercida sobre o veludo estimula a resposta em uma projeção de vídeo de uma figura feminina, contra um número de backgrounds elementais. Os gestos de proximidade e toque dos espectadores acionam um resistor de força sensitivo e um sensor de campos eletromagnéticos colocados debaixo da mesa que acionam por sua vez sons e modificações nas imagens projetadas em videodisk. O corpo a partir dessas interferências pode tremer, se afogar na água, desintegrarse, morrer, dormir.

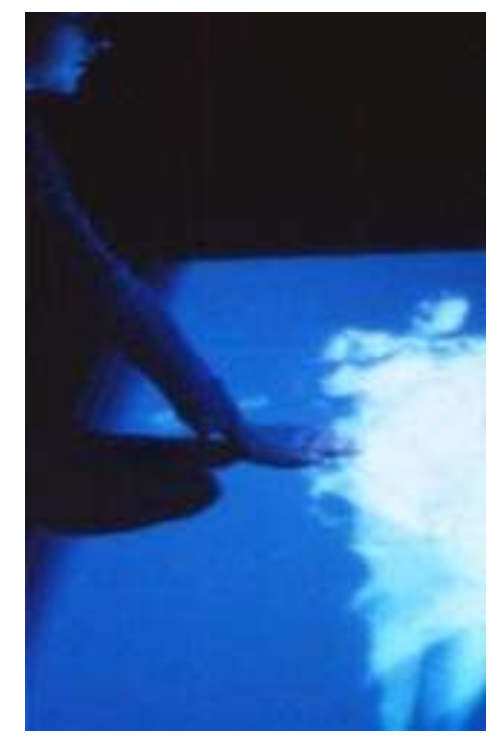

Figura 38: Thecla Schiphorst. Bodymaps: artifacts of touch Fonte: http://www.sfu.ca/ tschipho/html/artDesign.html

No próximo capítulo desenvolveremos análises de obras que se inserem na pesquisa sobre superfícies diferenciadas de projeção e descreveremos os trabalhos de nossa autoria que foram realizados antes de nossa entrada no mestrado e durante o estudo. Ressaltamos que estes trabalhos foram a motivação da pesquisa. 


\subsection{Análise de obras}

\section{3.1 Experiência de cinema/ Rosângela Rennó / 2004}

Rosângela Rennó é uma fotógrafa que trabalha desde 1980 com apropriação de imagens ao invés de fotografar. Segundo Herkenhoff (1996, p. 6) o ato da artista de ser uma "fotógrafa que não fotografa" é uma forma de economia em um "mundo marcado pelo excesso de imagens" (HERKENHOFF 1996, p.6). Em entrevista a Paulo Herkenhoff (1996, p. 12) Rosângela Rennó comenta sobre suas referências iniciais no uso de apropriações de imagens:

\footnotetext{
Quem me introduziu na 'atmosfera' da apropriação de imagens foi Marcelo Kraiser, também por um tempo, companheiro de atelier (uma espécie de colega mais velho e, portanto, mais experiente), através do texto de Andreas Muller- Pohle sobre a necessidade da 'ecologia da informação'. Outra leitura importante da época foi o delicioso A Filosofia da Caixa Preta, de Villém Flusser.
}

A artista se apropria das imagens e as descontextualiza, deslocando-as para o campo social de circulação. As apropriações são diversas: de álbuns de família, de fotos abandonadas em estúdios, fotos encontradas em museu penitenciário, imagens de jornais, textos de várias fontes etc. Posteriormente ela manipula essas imagens e textos que coleciona.

Segundo Paula Alzugaray, a artista trabalha alterando imagens (principalmente fotográficas) e textos de modo a dificultar a legibilidade, seja alterando o contraste na cor quando manipula as imagens, seja pela incisão de cortes nos textos, "eliminando referências geográficas, temporais e identitárias.” (ALZUGARAY, 2004, p.1). Desta forma, cria lacunas para o espectador preencher e cria ficções de documentos e imagens da "realidade". Segundo Alzugaray, a artista trabalha texto e imagens moldando-os: "de acordo com o interesse de torná-los aptos a representar não apenas um acontecimento, ou um personagem, mas qualquer um. [...] Suas operações de redução transformam imagem e texto em espaços brancos, potencialmente preenchidos pelo espectador. O que era notícia de jornal torna-se espelho.” (ALZUGARAY, 2004, p.1)

Segundo Alzugaray (2004, p.2), a artista escolheu trabalhar mais intensamente com apropriações e passou a deixar de fotografar, quando vivia em Belo Horizonte por volta de 1980. Nessa época, priorizou trabalhar com imagens de álbuns de retratos. Desse interesse, produziu obras como, a série Pequena ecologia da imagem, escolhendo dos álbuns encontrados as fotografias que tinham menor legibilidade: imagens fora de foco, escurecidas, apagadas. Prossegue sua pesquisa investigando "memória, a identidade e seus apagamentos." (ALZUGARAY, 2004, p.2).

Segundo Alzugaray, (2004, pp.2-3) o interesse pela coleção tanto de fotos como de 
textos foi importante para a estratégia de seus trabalhos. Nas palavras da artista, o interesse pela apropriação se deu quando percebeu que não precisava mais fazer suas próprias imagens e que mesmo assim poderia continuar "dentro do universo fotográfico". Eis o que diz::

$\mathrm{O}$ ato fotográfico é apenas um gesto. Existe todo um léxico envolvido, desde a produção, à edição até a finalização, que são muito mais interessantes do que o ato em si [...] Quando contatei, pela primeira vez, o estúdio de fotografia mais conhecido do Rio de Janeiro, que estava prestes a colocar no lixo todos os negativos reunidos ao longo de sei lá quantos anos, entendi a dimensão do que significa "arquivo morto". Apenas nessa altura percebi o que era um arquivo, que nunca foi propriamente um arquivo mas, na verdade, já era um "arquivo morto" e já estava destinado ao lixo. Foi desse volume que nasceram várias das minhas preocupações, não só em relação ao processo fotográfico como, também, a um possível ciclo de vida da fotografia. Detetar a morte da imagem e a função que ela cumpre são tarefas simples, o que é difícil saber é quem decreta, e porquê decreta, a sua morte. (RENNÓ, 2012) ${ }^{37}$

Em Herkenhoff encontramos:

“As referências de Rennó à história da fotografia não se afirmam no citacionismo de imagens clássicas, mas como operação dos procedimentos e atitudes de um trajeto desde a câmara obscura". A artista trabalha com fotografias encontradas, em ateliers populares, recolhidos de jornal, "fotos de obituários e de identificação criminal." (HERKENHOFF,1996, p.6)

Segundo Alzugaray (2004, p.3), Rosângela Rennó é apontada como uma das primeiras artistas brasileiras a deslocar a fotografia para o campo da instalação artística e assim trabalhá-la em campo expandido. A artista mais do que se preocupar em fotografar centra sua pesquisa em investigar a fotografia, seus usos sociais, o ciclo das imagens, a expansão da imagem e como em sua obra Arquivo Universal (work in progress que teve início em 1992) em que trabalha o texto manipulando-o da mesma forma que manipula as imagens e ainda trazendo (imaginariamente) pelo texto as imagens aos espectadores. Ainda dentro das preocupações da artista está a forma de apresentação dessas imagens, destes textos (que é o princípio da instalação).

Alzugaray (2004, p.4) lembra que a artista ainda incorpora em suas obras as questões relacionadas às imagens em movimento desde suas aulas de cinema. Essa incorporação é observada já em suas primeiras exposições individuais por volta de 1989. Anti-Cinema, exposição realizada em 1989, na Galeria Corpo, em Belo Horizonte, compôs-se de várias obras e em uma delas Rosângela montou fotografias sobre discos LP que eram rodados em toca-discos, prestando nesta exposição homenagens a: Muybridge e Etiene-Jules Marey e também a Marcel Duchamp e Jan Dibbets.

\footnotetext{
${ }^{37}$ Texto disponível em: http://www.parqmag.com/?p=14042. Acessado em 10 abril de 2014
} 
Ainda segundo Alzugaray (2004, p. 4), em Lição de realismo fantástico (1991), a artista também aponta relações com o cinema, utilizando projeção de imagens em movimento que saíam de um pedestal e apresentavam imagens fantasmagóricas girando sobre as paredes. "o dispositivo evocava um sistema muito antigo de produção de "fantasmagorias", comum às lanternas mágicas giratórias do século 18.” (ALZUGARAY, 2004, p.4)

Dentro da pesquisa geral sobre a artista e as ampliações no modo de exibição das imagens, percebemos que ela trabalha no sentido da expansão da fotografia para além de sua apresentação bidimensional e enquadrada. Nos modos de apresentação a artista ainda trava relações com o cinema, como exposto acima, incorporando assim em seu trabalho imagens projetadas, aparatos associados ao cinema, pré-cinema como o uso de lanternas mágicas e também telas diferentes das tradicionais de sala de cinema (foco de nosso estudo). Trataremos agora de analisar brevemente a obra Experiência de cinema (2004). Esta obra foi escolhida para nosso estudo por trabalhar com apresentação de imagens projetadas em tela não convencional.

\title{
Experiência de cinema (2004)
}

Nesta obra, Rosângela Rennó, como em seus outros trabalhos, usa a apropriação de imagens, mas, diferentemente dos outros, aqui realiza a projeção fotográfica sobre cortina de fumaça intermitente. Esta tela é volátil, e segundo Rennó:

\begin{abstract}
uma cortina de fumaça que permanece no espaço apenas alguns segundos, deformando, distorcendo, dando espessura e movimento às imagens estáticas.[...] Uma homenagem aos ilusionistas e criadores da imagem em movimento, o projeto foi concebido como um experimento de arqueologia do cinema, se reportando às primeiras experiências de viagem de imagem, através de mecanismos de projeção e das lanternas mágicas, realizadas entre os séculos 16 e 17. (RENNÓ) ${ }^{38}$
\end{abstract}

Observamos pelo escrito acima que a artista tem uma preocupação com a superfície que receberá as imagens projetadas e que existiu todo um preparo para que a tela tivesse um formato, uma duração, e que ainda é a tela, sua materialidade que produz alterações nas imagens durante a exibição (ganham mobilidade, espessura). Mais à frente do texto a tela será melhor observada em seu tratamento e tecnicamente.

Nesta obra a artista trabalha com sequências de fotos editadas e dispostas a serem apresentadas temporalmente em vídeo em DVDs. As fotos estão divididas em quatro

\footnotetext{
38 http://www.bienalmercosul.art.br/7bienalmercosul/en/rosangela-renno. Acessado em 19 de abril de 2014.
} 
programas: "filme de amor", "filme policial", "filme de guerra", e um "filme de família". (Rennó). ${ }^{39}$ Cada um destes programas segundo Biscainho (2012, p.18), contém 31 fotografias. Cada foto projetada (dos programas) surge a cada 30 segundos e tem duração de 11 segundos. As fotos são manipuladas digitalmente no que se refere, por exemplo, ao enquadramento, cor e as imagens da obra provêm de:

\begin{abstract}
[...] álbuns de família adquiridos pela artista e oriundos de vários pontos do mundo, "achados" fotográficos em estúdios populares, registros mantidos em arquivos prisionais (Museu Penitenciário Paulista files), imagens dadas a conhecer por jornais (A Folha) e agências noticiosas internacionais (Black Star, Magnum Photos, Sygma, AFP Photo, Reuters Agency, Pacemakers Press) e brasileiras (Agência O Globo) [...] Entre imagens reconhecidas, como as captadas por Eric Schwab no campo de concentração de Dachau após a chegada do exército americano, a de Jens Schlueter que mostra a cientista Jane Goodall na companhia de um chimpanzé, ou ainda um dos registros de Stan Honda no 11 de setembro, Rosângela Rennó apresenta imagens captadas por anônimos. Destas últimas fazem parte algumas fotografias usadas pela artista em trabalhos anteriores, nomeadamente, as que eternizam cenas de casamento, reunidas em "Cerimônia do Adeus" [...] bem como, as que revelam tatuagens ou marcas de reclusos da Penitenciária do Estado de São Paulo, e que compõem a série “Cicatriz”.(BISCAINHO, 2012, pp.18-19)
\end{abstract}

Essas imagens como exposto acima, vêm de diversas fontes, inclusive alguns dos trabalhos anteriores da artista como a Cerimonia do Adeus, (2003) obra com fotografias de recém-casados sentados no interior de carros ou em motos, a série Cicatriz (1996) que seriam fotos encontradas no setor de Psiquiatria e Criminologia da Penitenciária do Estado de São Paulo, onde tinham o objetivo de identificar os prisioneiros por suas marcas e cicatrizes. Essas duas obras retomadas pela artista para este trabalho aprofundam segundo Biscainho (2012, p.20), o uso da fotografia para: as tradições familiares em torno da fotografia (como acontece em Cerimônia do Adeus) e o uso da fotografia pelos sistemas de poder (como acontece em Cicatriz).

Em Experiência de cinema, a artista reúne o uso da fotografia tanto na esfera privada como na pública e, segundo o autor (2012, pp.20-21) misturando imagens de anônimos ora que foram abandonadas em estúdios ora que foram retiradas de jornais, confere aos anônimos certa visibilidade (colocando-os em jornais, revistas) com fotos de pessoas mais conhecidas assim como acontecimentos mais marcantes. Nesse sentido, a artista coloca em confronto a narrativa oficial e a narrativa pessoal comum, que foi vista como insignificante e desvalorizada.

O modo como apresenta esta obra (como em muitas outras) pretende dificultar o imediatismo, a banalidade de apresentação e leitura das imagens. Sua finalidade, dentre outras,

\footnotetext{
${ }^{39}$ http://www.bienalmercosul.art.br/7bienalmercosul/en/rosangela-renno. Acessado em 19 de abril de 2014.
} 
é apresentá-las sobre uma superfície volátil que tem uma duração curta para observação e ainda, dentro desta duração curta, as imagens são apresentadas deformadas, distorcidas.

A obra é ligada por vários elementos, e a tela é um elemento essencial, pensada em seu formato, em seu tamanho e em mecanismos para controlá-la (isto é, controlar a fumaça e assim a visibilidade das imagens). Podemos observar essa preocupação no dispositivo escolhido pela artista, o tubo de distribuição de fumo em formato $\mathrm{T}$, descrito por Biscainho (2012, p.60) como "um elemento em forma de "T" que encaixa na saída do fumo da máquina e condiciona o fumo na formação de uma cortina, através dos 103 orifícios que apresenta em linha recta ao longo de sua barra horizontal”. (Biscainho, 2012 p. 60) Ainda segundo o autor, a barra horizontal mede $111 \mathrm{~cm}$ de comprimento.

Este suporte fica ligado a uma máquina de fumo sincronizada com o disparo de imagem. Biscainho destaca que, logo após um beep no vídeo, a fumaça se inicia e depois de alguns segundos a imagem é projetada. Segundo o autor (2012, p.47), a artista indica o fluxo luminoso do projetor entre 1000 e 1200 ANSI lumens Ele aponta como razão de escolha para esse fluxo luminoso a própria intenção da artista, isto é, que as imagens pareçam imateriais e também devido à projeção frontal em relação ao espectador, pois olhar diretamente para a luz não é aconselhável, assim, essa retroprojeção seria confortável aos espectadores. Segundo ele, a artista prefere um fumo mais espesso para que não seja desmanchada tão facilmente a cortina de fumaça pela corrente de ar que possa ocorrer no espaço expositivo. (BISCAINHO, 2012, p. 37)

Aliados à tela estão outros elementos para orquestrar essa duração, formato etc., como a sincronia do disparo da imagem, juntamente com o disparo da fumaça por uma máquina de fumo ligada ao suporte em $\mathrm{T}$ e ainda sistemas de exaustão de fumo, que são inseridos no espaço expositivo por duas razões principiais, segundo Biscainho (2012,p 63): a qualidade da projeção é diferente se permitir acumulação de fumaça e o glicol pode contaminar outras obras. A extração de ar deve estar localizada no teto para que se mantenha a orientação vertical da cortina. Mas a obra também pode ser apresentada sem extração de fumo, desde que não existam outras obras no local e que o pé- direito seja alto para que o fumo suba. Por isso, o local deve ser amplo para que não exista concentração de fumo. (Biscainho 2012, p.64)

Em relação ao espaço para apresentar a obra Biscainho (2012, p.65) utiliza- se de documentos nos arquivos MUSAC e da Coleção Geral de Depósitos para montagem e instalação da peça :

Distância do projetor de vídeo ao tubo ' $\mathrm{T}$ ”; entre $2,5 \mathrm{~m}$ e $4 \mathrm{~m}$, dependendo do projetor escolhido.

O observador deverá estar posicionado numa zona para visualização da peça que deverá ser entre 3 e 6 m de distância do tubo "T". 
A largura de projecção deverá ser $110 \mathrm{~cm}$, o que corresponderá a uma altura projectada de $82,5 \mathrm{~cm}$.

$\mathrm{Na}$ entrada do espaço de exposição deverão estar impressas, juntamente com a legenda da peça, a lista de créditos das imagens utilizadas no vídeo projetado. (BISCAINHO, 2012 ,p. 65)

Vale ainda destacar algumas condições para apresentação da obra utilizando apontamentos e indicações de Biscainho (2012, pp.65-66): a inalação de fumo não é indicada por muito tempo, causando prejuízo à saúde, pois pode acarretar irritação no trato respiratório em pessoas que não tenham problemas respiratórios. Já em outras que tenham asma, por exemplo, a inalação poderá agravar seu estado de saúde. Portanto,, fica fortemente indicada a extração de fumo do local.

A luminosidade deve ser constante e de preferência a projeção deve ser feita em local escuro, embora também possa ocorrer com alguma luz no ambiente. O local de exibição não deve ter correntes de ar, pois estas podem interferir na formação da cortina e assim na visualidade da obra.

Sobre o vídeo, como observado anteriormente, é composto por quatro programas: Crime, Guerra, Família, Amor e em cada um desses programas existem 31 fotografias (todas as fotografias devem ser acompanhadas de créditos no final e na placa de descrição da obra). No total, segundo Biscainho (2012, p. 39) são 124 imagens. As imagens de cada programa foram compiladas pela artista em um único DVD, sendo possível uma projeção contínua, isto é, sem troca de DVD, mas também existe outra possibilidade oferecida pela artista para a distribuição das imagens. Esta outra possibilidade de apresentação e distribuição das imagens em DVDs é referida na entrevista de Pip Laurenson a Rosângela Rennó via e-mail, consultada na Tate Stores por Biscainho (2012, p.39). A artista deixa em aberto e sob escolha da curadoria duas possibilidades de apresentação relacionadas aos DVDs. Pode ser apresentado um único DVD com apenas um programa durante cada dia ou semana e depois alterado por outro programa, ou então pode-se apresentar um DVD com os quatro programas. Em resumo, foram entregues em cada instituição à qual a obra pertence um único DVD com os programas compilados ou quatro DVDs com os programas separados.

Segundo Biscainho (2012, p.41), as imagens que estão nos DVDs foram todas editadas digitalmente por Fernanda Bastos e Isabel Vidor para que tivessem o melhor efeito quando projetadas na fumaça.

E ainda segundo ele (2012, p 43), as imagens todas apresentam três fases de projeção: fade in, imagem projetada e fade out e estão em sincronia com o disparo e aparecimento da fumaça. A fumaça inicia sempre um pouco antes do que o disparo da imagem, que começa 
com fade in, fica projetada e vai desaparecendo em fade out assim como a fumaça. "A máquina de fumo é o elemento que recebe o sinal de áudio em reprodução no vídeo da obra e o interpreta como um sinal de controle remoto, como consequência vai produzir e expelir o fumo no tempo certo em que a imagem aparece.” (BISCAINHO, 2012, p.50)

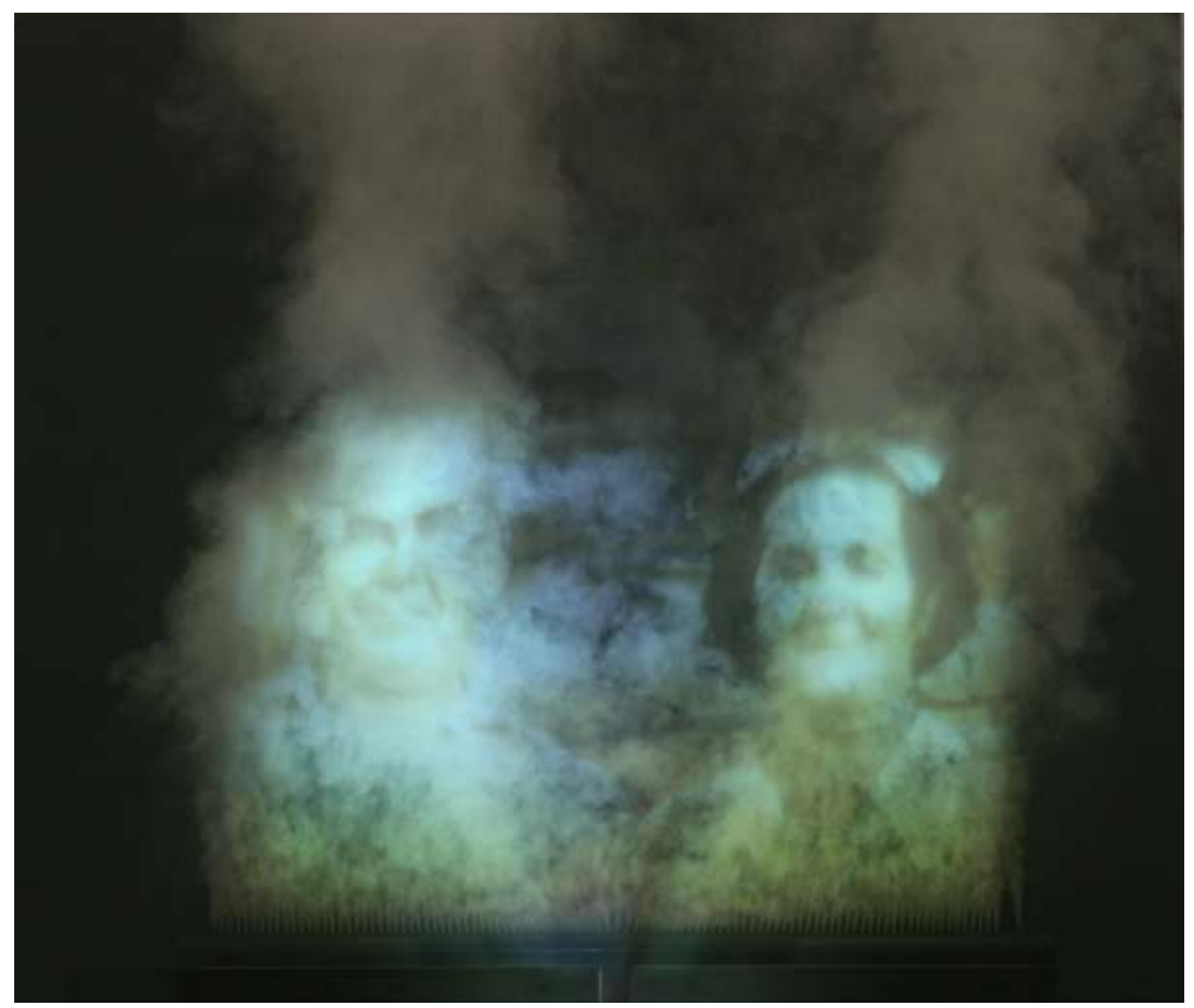

Figura 39: Rosângela Rennó. Experiência de Cinema 2004-5

Fonte: http://www.semeiosis.com.br/a-fotografia-expandida-no-contexto-da-arte-contemporanea-uma-analiseda-obra-experiencia-de-cinema-de-rosangela-renno/

\subsubsection{The Influence Machine (2000) / Tony Oursler}

Tony Oursler trabalha com pintura, desenho, escultura, vídeos e instalações nas quais se utiliza frequentemente de imagens em movimento projetadas em superfícies não convencionais como: flor, objetos, árvores, bonecos, fumaça etc. Este uso foi o motivo da 
escolha da obra do artista nesta dissertação.

$\mathrm{O}$ artista liberta a imagem da tela, do monitor usando outras superfícies, formatos e assim, segundo Venancio:

\begin{abstract}
oferece às imagens uma autonomia inédita, surpreendente e desconcertante [...] Fora dos limites prescritos da tela, não sabemos mais de onde essas imagens vieram, onde estão, para onde vão; livres, mas desorientadas, desprotegidas, também inquietas e angustiadas, sem saber o que fazer, como se comportar, falar, agir [...] Rompida a separação tácita, a divisão convencional entre dois mundos, o mundo real e o mundo da imagem passam a se confundir, se contaminam, cada vez mais indistinguíveis e inseparáveis [...] (VENANCIO, 2011, pp. 7-8 )
\end{abstract}

As imagens libertadas desse enquadramento da parede ou do monitor se encontram pelo espaço surpreendendo e confrontando quem passa por elas. $\mathrm{O}$ artista trabalha segundo Kelly Gordon ${ }^{40}(2008$, p. 61), com pequenas ou grandes projeções muitas vezes rostos e olhos que são quase sempre distorcidos e que "tomam a forma de suas superfícies hospedeiras cilindros, cubos, esferas, bonecos de pano, até mesmo árvores [...] (GORDON, 2008, p. 61, tradução nossa)

Começaremos comentando brevemente a pesquisa do artista para analisarmos sucintamente a obra Influence Machine (2000).

O trabalho de Tony Oursler tem dois princípios fundamentais segundo Bellour41 (2013, p. 8): a reinvenção da projeção, a qual o artista divide e expande, quando projeta rostos e cenas sobre criaturas poliformes e a criação de um mise in scene para os seres (que sofrem, gritam, reclamam, riem) no espaço expositivo. Venancio (2011) complementa as afirmações de Bellour e diz que na obra do artista há um excesso de distorção tanto de vozes quanto de forma. Venancio (2011, p.9) destaca que os bonecos de Tony Oursler são encontrados (nas exposições) em locais mais inusitados, fora da vista mais imediata, quase sempre embaixo de móveis em posições esquisitas, difíceis até de se ver se não fossem os sons que são produzidos incessantemente por eles. São vozes, monólogos, palavras ruídos, irreconhecíveis. E segundo o autor, "se há um traço comum entre eles é a incansável capacidade de falar; tal como os aparelhos, eles estão sempre ligados, nunca desligados.” (VENANCIO, 2011, p.9)

Os temas principais de Oursler remetem à vida contemporânea diária, "tais como a relação com os meios de comunicação, a doença mental, cultura pop, consumismo e poluição.” (MORATTI, apresentação do catálogo, 2011, tradução nossa)

40 GORDON, Kelly. "Projections Dreams.” IN: BROUHER, Kerry et al.(ORG.). The cinema Effect: Ilusion, reality, and the moving image. Smithsonian Hirshhorn Museum and Sculpture Garden, 2008. Disponível em: , http://tonyoursler.com/files/HH-cinema-p1-176-ad2\%208.28.07.pdf Acesso: 21 de maio de 2014 41 BELLOUR Raymund. "Cinema, Alone"/Multiple "Cinemas" Alphaville: Journal of Film and Screen Media Issue 5, Summer 2013 Translation by Jill Murphy disponível em http://www.alphavillejournal.com/Issue5/HTML/ArticleBellour.html Acesso em 16/05/2014 
A patologia MPD Multiple Personality Disorder interessa ao artista desde 1992 e é recorrente em sua obra, segundo Paparoni (2011, pp. 14 - 15) podendo ser observada fortemente em Judy (1994). Trata-se de uma instalação em que a divisão da personalidade de um esquizofrênico fica representada em quatro figuras diferentes, dispostas fisicamente pelo espaço. O inconsciente de Judy é representado por uma mulher nua, em posição fetal, projetada sobre vestido com flores; a divisão da personalidade é ainda representada por mais três bonecos, chamados de Horror, Boss e Fuck You animados pela técnica de projeção de vídeo. Expressam estados de espírito contrastantes, como raiva, frustração e depressão. Segundo Almazán (2012), Boss um dos alter ego aparece projetado sobre um ramo de flores artificiais e emite ordens e ameaças. Já Fuck You (outra identidade de Judy) fica escondido debaixo de um sofá levantado. Ele fica olhando para os espectadores e através de palavras, os expulsa, pedindo-lhes, com palavras obscenas, que não o fiquem olhando. Oursler também mostra o efeito da mídia sobre os estados psicológicos como identificação, a empatia, medo, raiva. Ressalta a ligação entre doença mental e possessão demoníaca. Certas síndromes psiquiátricas são vistas por muitos como possessão e alguns acreditam que essas manifestações de loucura devem ser tratadas por exorcistas e não pela psicanálise. Oursler (1994)42 afirma que a patologia do transtorno de personalidade múltipla ocorre com mais frequência em pessoas que passaram por traumas sejam eles sexuais, por violência ou por traumas psicológicos, e esta divisão em outras personalidades seria uma defesa para proteger o "ser nuclear". Segundo Gordon (2008, p.81), Ousler:

[...] descreve seu trabalho como psychomimetamedia e tem se referido como o Transtorno da Personalidade Múltipla, que se pensava ser uma condição clínica agora é estudada como uma forma contemporânea de histeria causada pela cultura da mídia. Ele até usou os poemas e estudos de casos de paciente MPD como postos de escuta para alguns scripts seu pequenino promulgar popular. GORDON, 2008, p. 81)

Para Yayo Aznar Almazán (2012), ${ }^{43}$ Oursler não se limita a representação desta doença, ele vai mais longe:

se trata de relacionar una patología clasificada como tal con todo lo que afecta al individuo en
una cultura de soledad e incomunicación masificada. Por eso en su obra es inevitable percibir
una acusada sensibilidad respecto al impacto de las nuevas condiciones de masas, creado por
la inagotable influencia de unos medios de comunicación sobresaturados de imágenes
(siempre las mismas imágenes), en los recovecos de la intimidad psíquica del individuo. Y eso
sí nos interesa aquí porque todas esas voces y esas imágenes influyen en los sujetos
conformándolos. (ALMAZÁN, 2012)

42 OUSLER, Tony. Proposal for Judy and installation at Salzberg Kunstverein. 1994. Disponível em: http://tonyoursler.com/files/proposalforjudy.pdf (acesso em 28 de abril de 2014)

${ }^{43}$ ALMAZÁN, Yayo Aznar. Cuerpos de trapo, sujetos vacios. Revista, Re-Visiones \# Dos, 2012. Disponível em: http://re-visiones.imaginarrar.net/spip.php?article68 (Acesso em 10 de maio de 2014) 


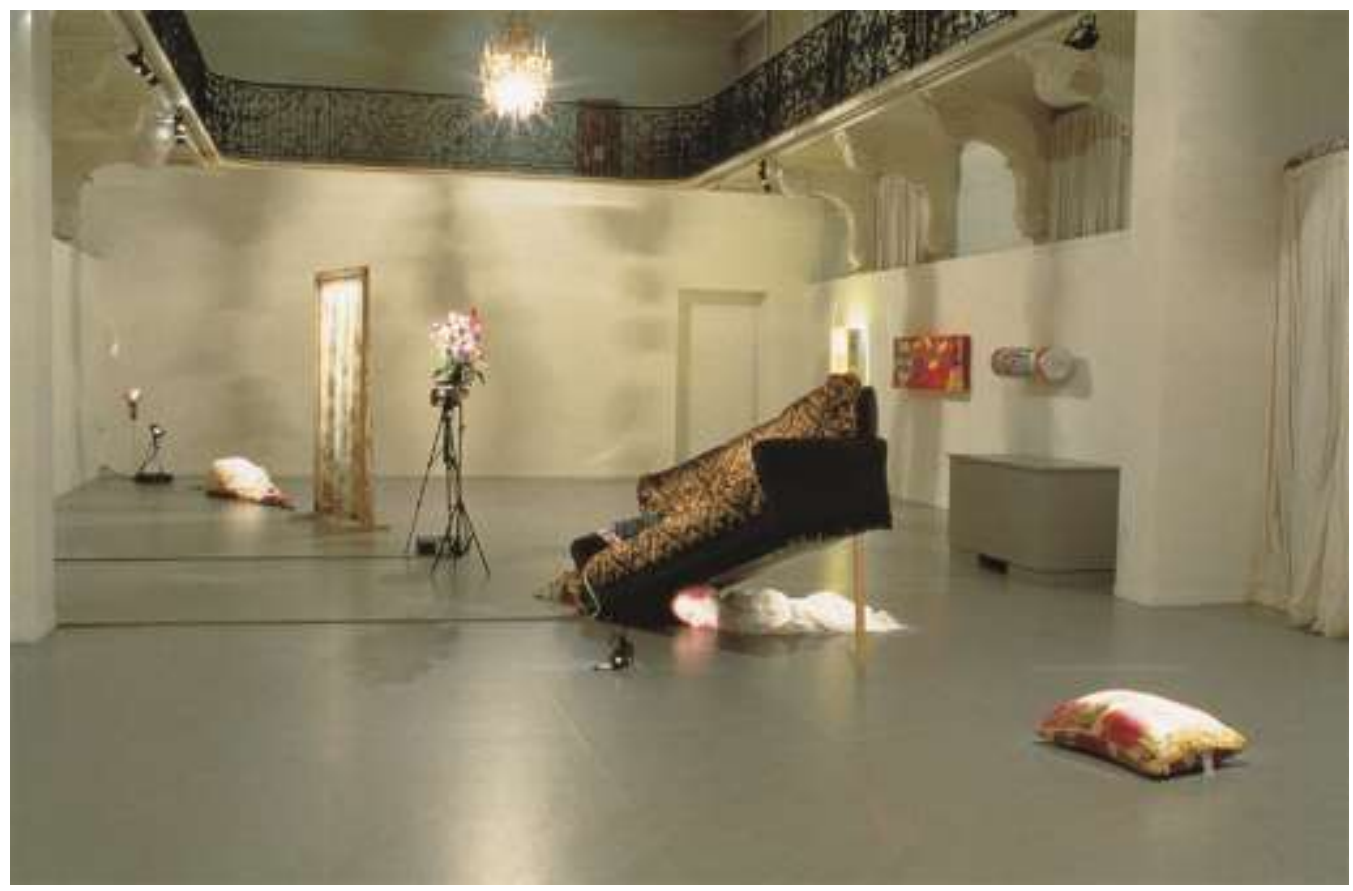

Figura 40: Tony Ourslet. Judy. 1994

Fonte:

http://tonyoursler.com/individual_work_slideshow.php?navItem=work\&workId=120\&startDateStr=Mar.\%201, \%201994\&subSection=Installations\&allTextFlg=true\&title=Judy

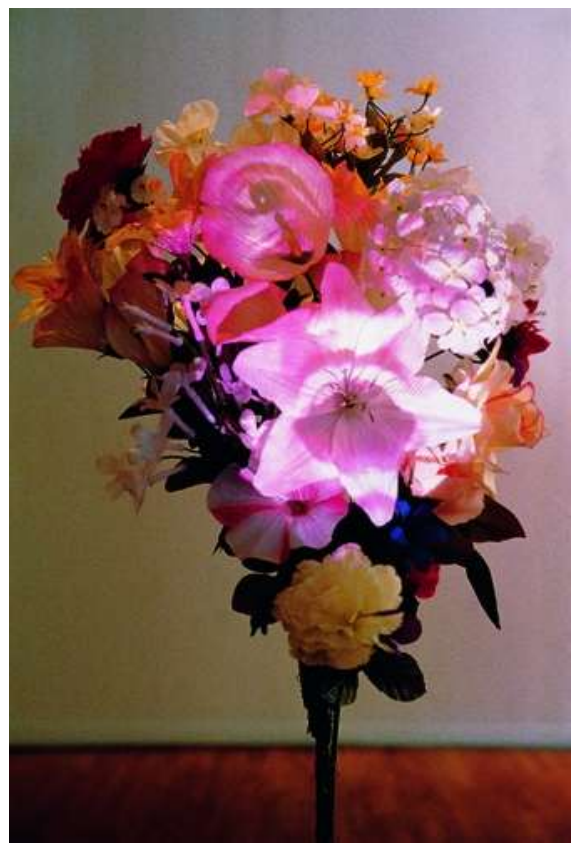

Figura 41: Tony Ousler. Judy. 1994

detalhe da obra.

Fonte:

http://tonyoursler.com/individual_work_slideshow.php?navItem=work\&workId=120\&startDateStr=Mar.\%201, \%201994\&subSection=Installations\&allTextFlg=true\&title=Judy\#!prettyPhoto[mixed]/10/ 
As obras de Oursler, são múltiplas em formas e formatos (sua fisicalidade) e, segundo Paparoni, (2011, p.11) vão desde bolas animadas de diferentes tamanhos onde ele projeta olhos que piscam e que assistem à TV e mudam de canal, (isto pode ser observado pelo reflexo do olho projetado) até massas informes nas quais olhos, lábios desarmônicos se aderem, ou ainda rostos que se materializam em árvores, fumaça, mas como diz o autor, o mais importante para Oursler é o envolvimento emocional do espectador.

Os sujeitos que ele apresenta pronunciam monólogos, falas:

atormentadas ou sem sentido sobre as condições mentais e experiências com que não gostariam de se encontrar. Eles são aparentemente encarnações demoníacas, mutantes de uma experiência de ciência mal sucedida, tumores cancerosos gigantescos causados pela poluição. (PAPARONI 2011, p. 11, tradução nossa)

E ainda segundo Paparoni (2011, p.13), Oursler deixa todo o equipamento à vista, isto é, os projetores, bonecos do que são feitos para tentar expressar a verdade sobre a natureza da escultura de animação, eles também nos dizem que a realidade é feita de ficção fílmica;

que nós somos frequentemente atores inconscientes de um filme filmado por outros; que nós somos os volumes em que as pessoas projetam a imagem que eles querem ver de nós; que estão a nos moldar à imagem e semelhança daquilo que estamos olhando. (PAPARONI 2011, p.13, tradução nossa)

Como observado por alguns dos exemplos trazidos por nós e pelo escritos acima, o artista usa a projeção sobre diferentes superfícies retirando a imagem da tela, e assim a separação entre esta e o espectador, traz para o espaço expositivo as formas dos objetos, mesmo que estes estejam deformados ou recortados (como vimos pelo exemplo da obra Eyes que apresenta olhos gigantes sem corpos). Escolhe projetar imagens sobre formas e superfícies deformadas unindo esta escolha ao tom de voz às falas que os personagens proferem para expressar um sentimento, um estado de espírito e as relações entre mídia e o estados psíquicos. 


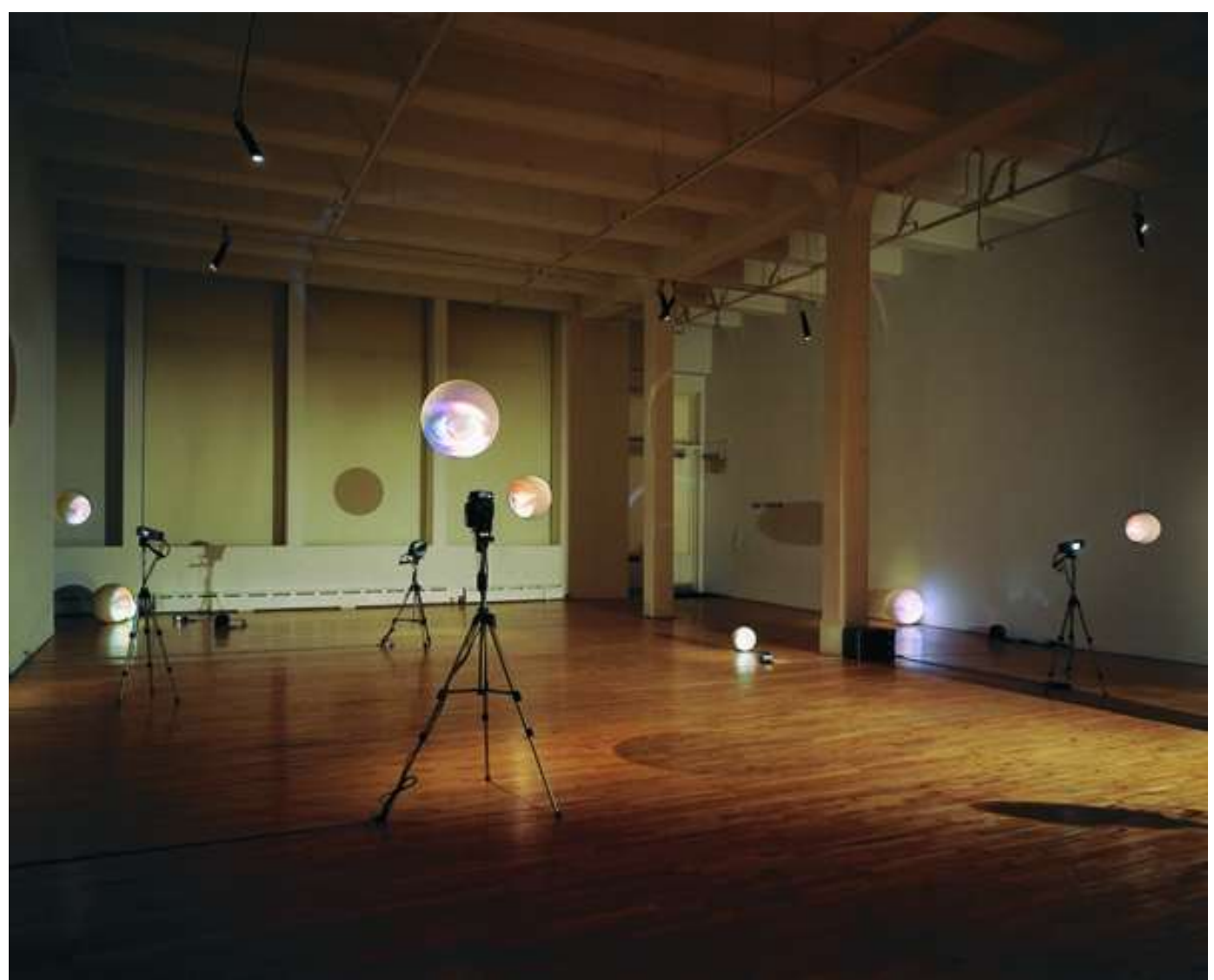

Figura 42: Tony Ousler, Eyes. 1996

Fonte:

http://www.tonyoursler.com/individual_work_slideshow.php?navItem=work\&workId=170\&startDateStr=Aug.\% 2010,\%201996\&subSection=Installations\&allTextFlg=true\&title=Eyes

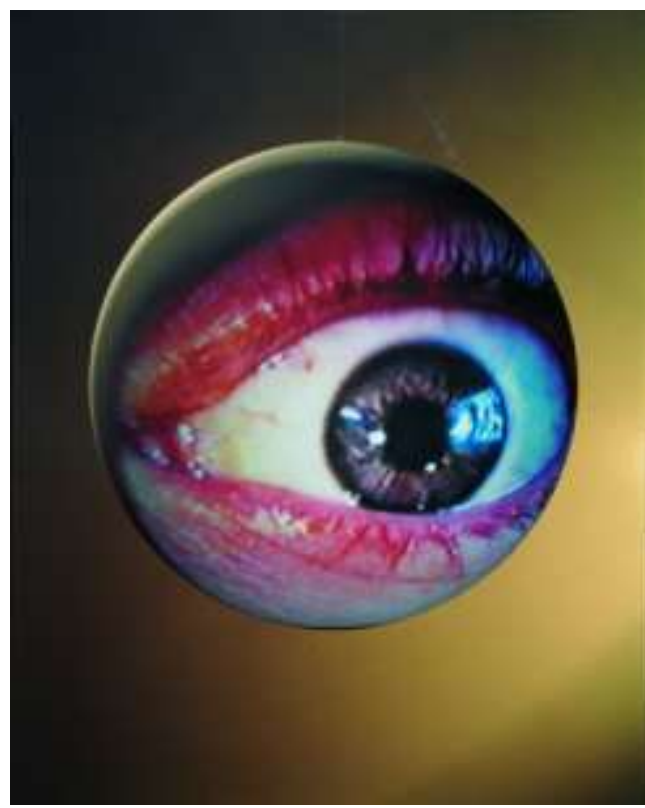

Figura 43: Tony Ousler. Eyes. 1996.

Detalhe da obra. Fonte:

http://www.tonyoursler.com/individual_work_slideshow.php?navItem=work\&workId=170\&startDateStr=Apr.\% 2020,\%201996\&subSection=Installations\&allTextFlg=false\&title=Eyes\#!prettyPhoto[mixed]/2/ 
Os objetos que usa para projetar vão desde esferas, efígies44, como o artista se refere aos objetos escultóricos que utiliza, espelhos, bonecos com cabeças falantes mas com corpos sem vida, fumaça, árvores e todo tipo de material e suporte inesperado. O artista amplia assim o dispositivo tradicional associado ao cinema, rompendo com o retângulo tradicional da tela de cinema ou de monitor e pesquisa superfícies, formatos, materiais para receber a projeção, aproximando-se, tanto pelo uso de esculturas como pelos materiais que escolhe, dos procedimentos das artes visuais.

Trataremos agora de uma obra que foi realizada pelo artista em espaço público. Nossa escolha se deveu ao uso de procedimentos de pré-cinema, como a retomada da fantasmagoria, da projeção sobre fumaça (dentre outras superfícies), e também pelo seu interesse na história das mídias, ressaltado nessa obra do artista.

\section{The Influence Machine (2000)}

Esta obra é uma instalação em espaço público em que o artista utiliza projeção de imagens sobre fumaça, árvores e edifícios, numa espécie de "psico-paisagem". Foi apresentada pela primeira vez em 2000 no Madison Square Park, em Nova York e logo depois em Soho Square, London WC1. Para Oursler, em entrevista a a Lynne Cooke45, (p. 84), Soho Square é um local muito propício à obra, já que interessam a ele as conexões entre várias camadas da realidade e da história. Este local tem um histórico interessante com os meios de comunicação (foco do artista em sua pesquisa da história das mídias). Foi nas redondezas de Soho Square que se situou o laboratório de John L. Baird, cientista do final do século XIX que inventou a televisão mecânica por volta do início da década de 1920. Ainda segundo Oursler em entrevista a Lynne Cooke (p.84) a obra faz referência ao gótico, a filmes de terror, espiritualismo e "certos tipos de tecnologia que são usadas para falar com os mortos", (Oursler entrevista com Lynne Cooke, s.d. p.84, tradução nossa)

Segundo Rubin ${ }^{46}$ (2014) quando uma tecnologia aparece ela tem vários usos e um desses usos acaba sendo ressaltado, abafando os demais. Para esta obra o artista traz um uso não tão divulgado da tecnologia: a comunicação com os mortos.

44 A obra do artista tem várias influências como: cinema, escultura e nesta, segundo Juan José Santos (2012, p. 85) http://www.revistasculturalesiberoamericanas.com/revistas/132/dardo-magazine/num/21/) as suas obras são como altares orgânicos, amorfos, estruturas sonhadas, conformadas pela escultura clássica, pensamentos sólidos que o artista chama de Efígies) Acesso em: 20 de abril de 2014

45COOKE, Lynne. Interview Lynne Cooke and Tony Ousler. S.d. Disponível para download em http://www.tonyoursler.com/files/lynne\%20cooke\%20interview.pdf (acesso em 28/04/2014)

46 RUBIN, Billy. Influnce Machine.2014 Disponível em

http://tonyoursler.com/individual text.php?navItem=text\&textId=82\&dateStr=Feb.\%2025,\%202014\&subSectio $\underline{\mathrm{n}=\text { Articles\&title }=\text { Influence\%20Machine, } \% 202000}$ (Acesso em 10 de maio de 2014) 
Tony Oursler em entrevista a Neri47 (2011), nos conta que Influence Machine assim como outras obras dele (Skulls and Still Lives , Empty Cabinet, The Darkest Color Infinitely Amplified, Through the Hole, Blue Transmission), nasceu de várias pesquisas em que surgiu uma linha do tempo desenvolvida pelo artista devido ao seu fascínio por formas de tecnologias como luz elétrica, cinema, óptica, rádio e a maneira como foram interligadas ao longo do tempo. Essa linha do tempo intitulada I hate the dark, / I love the light foi criada pelo artista para a retrospectiva dele no Williams College em 1998. O tema geral, segundo o próprio artista:

[...] foi a tecnologia mimética, ou seja, tecnologia que poderia ser entendido como uma extensão direta de estados psicológicos [...] eu peguei emprestado o termo "mimético" da farmacologia, onde ele é usado para descrever uma classe de drogas que imita estados psicológicos ou provoca estados elevados de consciência. Da mesma forma ou ainda mais eficazmente, a tecnologia cria um espaço de sonho que imita a realidade. (Oursler em entrevista a Neri , 2001, tradução da autora )

$\mathrm{Na}$ linha do tempo do artista ele tenta criar uma ligação entre coisas que não estavam associadas. Ele exemplifica esta intenção usando a história da arte e como nela foi tratada a câmara escura, por exemplo. Esta câmara foi vista como um mero auxiliar do desenho, mas ela é, segundo ele:

\footnotetext{
a primeira produção cultural do espaço virtual, instalação e o precursor do mundo mediado pela fotografia, cinema e tecnologias de vigilância. Uma vez que essas categorias fazem agora parte da história da arte, é importante que elas sejam integradas na narrativa central. Como um artista de mídia, eu queria fazer minha própria versão da história cultural que incorporou essas novas mídias e tecnologias. (Oursler em entrevista a Neri ,2001 Tradução da autora )
}

Ainda segundo o autor em entrevista a Neri (2001), a imagem em movimento foi aceita apenas recentemente na história da arte. A história das mídias sempre foi muito importante para ele, pois se interessa pela origem delas e também por suas "estruturas profundas", ou seja, como as pessoas interagem psicologicamente com os meios tecnológicos, e foi a partir desses estudos e pesquisas que o artista criou a base das suas próprias instalações.

As influências para Influence Machine foram diversas desde o título, as falas proferidas pelas figuras projetadas, os procedimentos usados, como projeção sobre fumaça, as figuras que projeta. Abordaremos algumas destas influências baseadas nas falas do artista na entrevista a Neri (2001) já mencionada. O título é comum a um objeto que foi considerado pseudocientífico na época em que foi apresentado e a um texto, ensaio de 1919 de Victor Tausk, que relata como os esquizofrênicos descrevem a sensação de estarem sendo

47 NERI, Louise. Smoke and Mirrors: tony Ousler”s Influence Machine. A conversation between tony Oursler and Louise Neri., 2001. Disponível em: http://www.artangel.org.uk//projects/2000/the influence_machine/smoke and_mirrors_a conversation/smoke_a nd_mirrors_a_conversation (acesso em 26/04/2014) 
influenciados por máquinas parecidas com seres. Segundo o artista, a ideia para Influence Machine vem de outras experiências e estudos, durante suas viagens a Londres, em que pesquisava e encontrava a documentação da invenção de Hauksbee do século XVIII, a máquina de influenciar, "um vácuo de vidro esférico que girava sobre seu eixo e emitia um brilho esverdeado quando esfregado [...] Em outras palavras, uma carga elétrica estática é introduzida no vácuo”. (Oursler entrevista a Neri, 2001, tradução da autora)

Essa máquina de influenciar, segundo Oursler, não teve importância científica em sua época; era um objeto pseudocientífíco usado em espetáculos e como um talismã. Na verdade, usava a mesma tecnologia básica da TV, o tubo de vácuo brilhante, o que levou o artista a afirmar que se tratava do primeiro aparelho de televisão e que a partir dele foram desenvolvidos várias outras invenções. A isso ele ligou figuras históricas como John Baird, o inventor da televisão mecânica. Outra referência para Influence Machine foi, de acordo com Ousler, seu contato com um historiador chamado Mark Cousins. Cousins apresentou a ele o texto de um aluno de Freud, Victor Tausk, intitulado The Influencing Machine . Neste texto, Tausk escreve sobre uma doença em que pacientes têm a sensação de estarem sendo atacados por uma máquina de partes mecânicas e elétricas semelhantes a um corpo.

Outra influência na obra do artista foram as leituras sobre telecomunicações. O texto de Jeffrey Sconce Haunted Media: Electronic Presence from Telegraphy to Television mostra isso. Era do interesse de Ousler o uso, a conexão, o telégrafo e outros inventos na comunicação psíquica.

Uma telecomunicação como o código Morse, por exemplo, inventado por Samuel Morse em 1844, permitiu que as pessoas se comunicassem a distância e seu uso foi também ampliado para comunicação com o além, como o caso de uma adolescente chamada Kate Fox, que se comunica com um morto (um vendedor ambulante) por batidas usando o sistema alfanumérico,

\footnotetext{
uma espécie "popular" de apropriação do código Morse. Suas atividades psíquicas causaram sensação paralela com o telégrafo, o que provocou o Movimento Espírita New American que existe até hoje. Essa relação entre a comunicação psíquica e de telecomunicações atravessa cada invenção sucessiva-rádio, a televisão, o computador. (Oursler entrevista a Neri ,2001, tradução da autora)
}

A pesquisa sobre o uso de mídias para comunicação com o além influenciaram então, como dito acima, a criação de Influence Machine, daí notar-se que a obra toma como ponto de partida o advento das telecomunicações e trabalha as relações com as "estruturas profundas de mídia”.

Encantando com as possibilidades trazidas pelas tecnologias e pelas invenções em 
geral, Ousler se interessa pela expansão da consciência humana e esta expansão, segundo ele, tornou os seres humanos mais sensíveis e com a crença de que poderiam tudo. Até cientistas como Edison segundo Oursler em entrevista a Neri (2001) acreditavam que poderia existir uma máquina que possibilitasse o diálogo com os mortos. Edison produz sobre isto um filme chamado A Visit to the Spiritualist.

Para Influence Machine (como para algumas outras) ainda o artista teve como influência o contato com as obras de Etienne-Gaspard Robertson (produtor de fantasmagorias do século XVIII), através dos escritos de Marina Warner e também das leituras que fez diretamente da autobiografia de Robertson e por ter presenciado a reconstituição da obra deste no Museu da Imagem em Movimento em Londres. Ao ler a autobiografia de Robertson, Tony Oursler observou o diálogo que Robertson travou com os mestres da óptica como Alhazen (século X) e Kircher (século XVII). Nesses escritos Robertson revela suas tentativas muitas vezes fracassadas de evocar o espírito Satanás, e descreve como inventou efeitos para fazer imagens dele. "Centenas de anos depois, Robertson me inspirou a reestruturar a minha própria linha do tempo de uma forma mais subjetiva, com base na escuridão e da luz." (Oursler entrevista a Neri ,2001, tradução da autora)

Oursler ainda relata que para dar voz aos personagens centrais de sua linha do tempo ele foi visitar com Tony Conrad a comunidade psíquica em Lily Dale (comunidade de médiuns em NY). Lá ele observou e gravou os médiuns, isto é, como eles canalizavam os espíritos.

\section{Breve descrição da obra}

The Influence Machine apresenta projeções de rostos sobre fumaça e árvores. Cada um dos rostos e figuras tinha seu específico script. Eram aparições de personagens históricos como as irmãs Fox (que realizavam uma comunicação com os mortos através de batidas), Étienne-Gaspard Robertson (praticante de fantasmagoria no século XVIII) e John Logie Baird (inventor da TV). Os rostos eram projetados na fumaça e seus scripts eram bem simples (para que não fosse perdido o conteúdo), eram mais apresentações de quem eram esses personagens, a data etc., por exemplo. "Vindo para você a partir de 1932, este é Baird", etc. As falas desses personagens históricos vinham através de dois performers interpretados por Sidney Lawrence e Tracy Leipod, como se fosse uma conversação com as imagens deles flutuando na fumaça.

Havia projeções de textos de rolagens baseadas em conversas encontradas, digitalizadas, em um computador, entre uma pessoa e um espírito. 
Uma mão gigante fechada e batendo era projetada em um edifício, fazendo uma referência às batidas como comunicação usadas pelas irmãs FOX e o espírito.

Além das falas dos personagens havia o som, que foi realizado por Tony Conrad e feito com gaita de vidro (instrumento usado por Robertson nas fantasmagorias).

Segundo Oursler (na entrevista a Neri 2001), foi muito importante a apresentação da obra em um parque, pois nesses espaços os espectadores podiam caminhar livremente sem a necessidade de uma posição fixa. $\mathrm{O}$ artista diz ter proposto algumas formas de o espectador se mover no espaço, podendo estes interceptarem a luz, a fumaça e assim afetar a própria projeção. No espaço externo tudo se dispersa, o som, as luzes, a fumaça, a projeção e também tudo é misturado a elementos da cidade, as luzes, o tempo etc. Assim, "o exterior é derramado na peça e a peça é derramada na cidade".

O trabalho foi desenvolvido com Fundo de arte pública em Nova York.

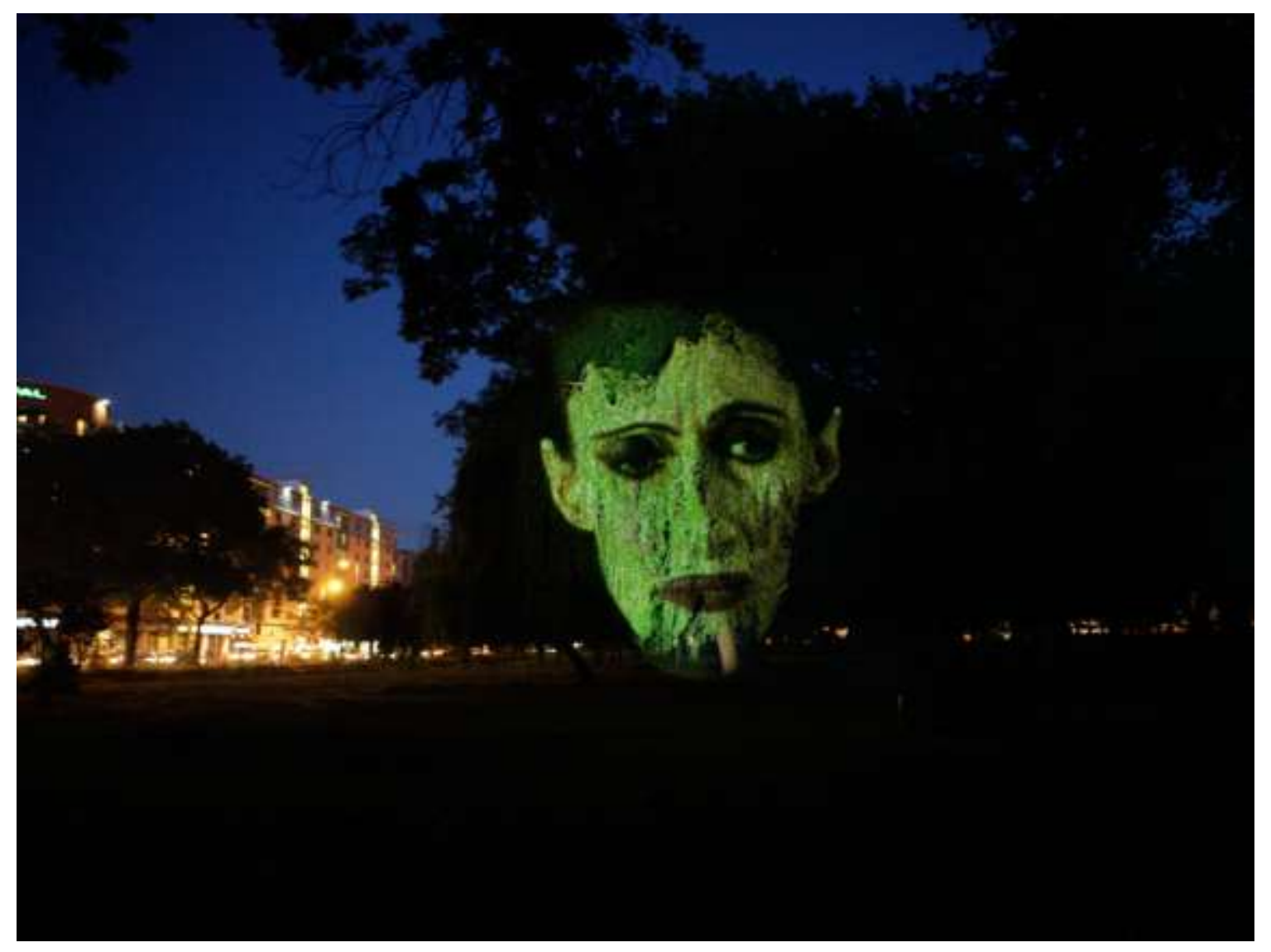

Figura 44: Tony Oursler. Influence Machine. 2000

Fonte:

http://tonyoursler.com/individual_work_slideshow.php?navItem=work\&workId=262\&startDateStr=Feb.\%2015, $\% 202013 \&$ subSection=Installations\&allTextFlg=true\&title=The\%20Influence\%20Machine\#!prettyPhoto[mixed ]/1/ 


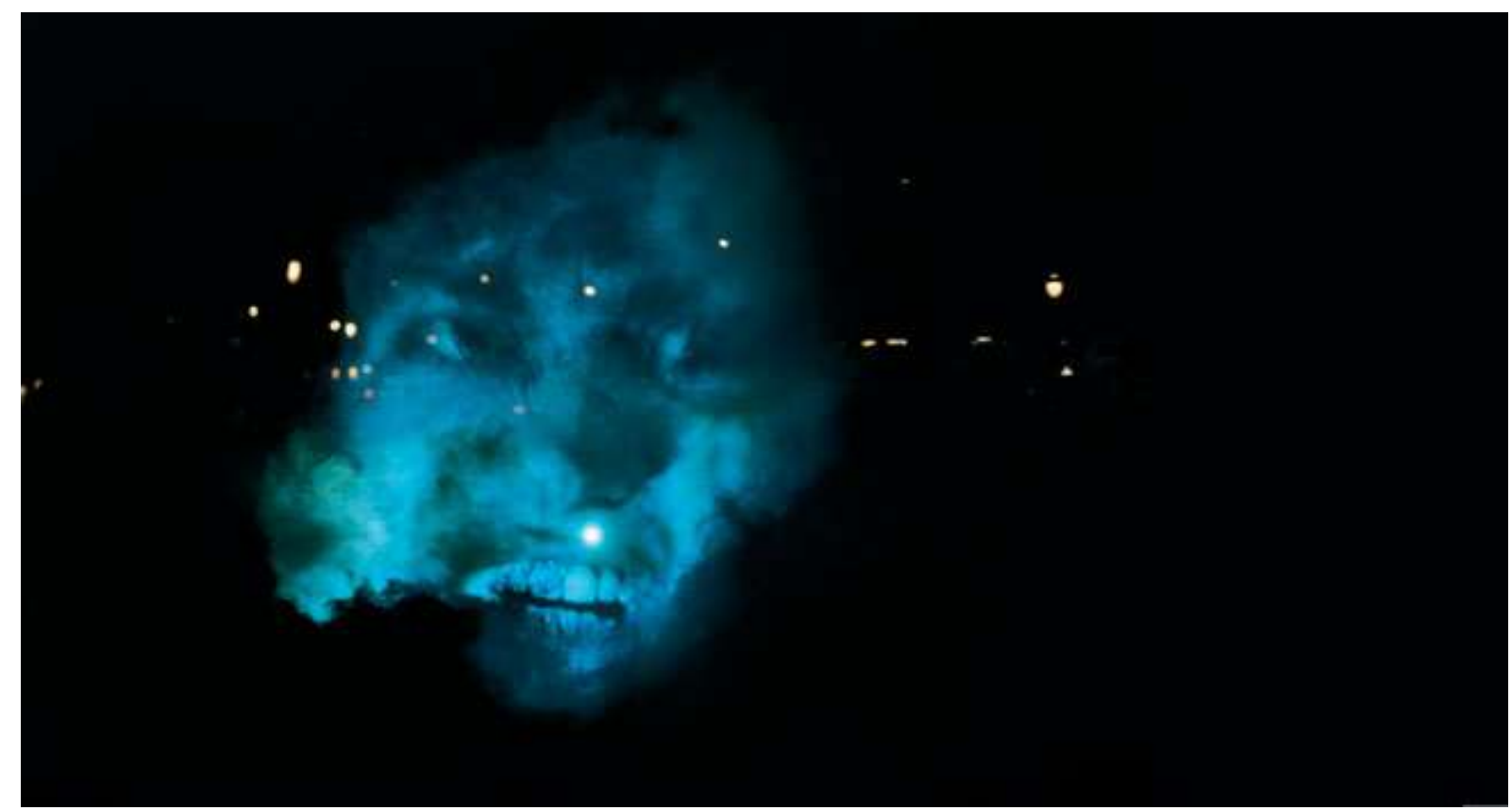

Figura 45: Tony Oursler. Influence Machine. 2000

Fonte: http://www.artangel.org.uk/projects/2000/the_influence_machine/monologues/medium_2

3.3.3 Cosmococas: Bloco de Experiências in Cosmococa- program in progress/ Helio Oiticica e Neville D’Almeida

Hélio Oiticica, artista brasileiro, juntamente com Lygia Clark (dentre outros) ressaltaram o ato de participação do público em suas obras. $\mathrm{O}$ artista cria o termo participador para se referir aos "espectadores", pois em suas obras estes faziam parte delas. Oiticica participou de vários Grupos. No Grupo Frente (1957), pesquisou as formas ainda dentro do quadro, posteriormente liga-se ao Grupo Neoconcreto (movimento de 1959 e 1961 que ocorreu no Rio de Janeiro que contou com pintores, poetas e escultores. Os artistas deste grupo trabalhavam fora do quadro, rompendo com o suporte tradicional da pintura, e assim trouxeram a obra para o espaço. Hélio Oiticica, integrante do grupo, cria seus Bilaterais (1959), relevos espaciais (1959) etc., mesclando nessas obras o espaço do espectador com o da obra. Assim também trabalha com o cinema, tentando liberar o cinema da tela de projeção e do modelo fixo de sala e gerando novas configurações para este. Oiticica escreveu sobre seus próprios trabalhos. Cosmococas, por exemplo, que terá algumas das obras da série analisadas nesta dissertação, acabou circulando, segundo Braga (2007, p. 17), mais por textos do que pelas obrsa em si, pois estas foram efetivamente concretizadas muito posteriormente a 
1973, ano de início dessas anotações e concepção da série.

Segundo Sperling (2008, p.126), o artista e Lygia Clark tinham em comum o propósito de "superação da arte como representação e a necessária investida da ação artística no espaço da vida cotidiana". Ainda segundo o autor, tanto Hélio como Lygia tinham essa vertente de forma individualizada em suas obras, mas estavam sincronizados com a vanguarda brasileira da época (1960-1970).

Para esta dissertação nós escolhemos analisar brevemente, como comentado acima, algumas obras da série intitulada Bloco de Experiências in Cosmococas - Program in Progress concebidas por Hélio Oiticica e Neville de Almeida. A série total conta com nove obras, mas nos deteremos nas cinco primeiras que foram realizadas pelos dois autores. Com essas cinco obras já podemos indicar a contribuição que as obras deram à arte ao modificar as formas de exibição de imagens em movimento e usar várias telas pelo espaço expositivo. A escolha da série se deveu, portanto, pelo alargamento que tais obras produziram na ideia de dispositivo cinematográfico e, assim, por irem muito além da forma cinema (espectador sentado, tela frontal e única, um projetor escondido, narrativa e o encadeamento de imagens fotográficas apresentadas a uma certa velocidade para que seja ocultado o seu componente estático). Cosmococas, segundo Maciel (2009, p. 281), "redimensiona a ideia do dispositivo cinematográfico, ao produzir uma nova sensação do espaço numa situação não narrativa". MACIEL (2009, p.281). Nestas obras são usadas várias paredes do espaço expositivo como telas, afastando-se o artista da exibição tradicional de cinema e produzindo uma maior participação do espectador, ao apresentar-lhe proposições, formas diferenciadas de vivenciar obras instalativas e utilizar imagens projetadas (slides) em sequência. Desafiava, assim, ”a passividade da plateia cinematográfica ao convidá-la a realizar ações dentro desta "caixa de imagens", expressão de Neville de Almeida". (CARNEIRO, 2008, p.191)

O título utilizado para a série, Bloco de Experiências in Cosmococas - program in progress, já resume, segundo Maciel (2009, p. 281), o conjunto experimental proposto.

Ainda quanto ao título, nele está presente a ideia de bloco, significando que a obra não tem uma continuidade entre uma experiência e outra. Cosmococas se refere ao uso de cocaína como elemento material da maioria da série e também Cosmococa, segundo entrevista de Neville a Carneiro (2008, p.190), fora inicialmente o nome do trabalho que Neville queria fazer como um projeto cinematográfico anterior a Cosmococas. Program in progress, segundo Maciel, trata-se de uma série sempre em desenvolvimento e aberta ao participador.

As obras são “identificadas pela abreviatura $\mathrm{CC}$, seguida de um número marcando a 
sequência cronológica da sua invenção”. (CARNEIRO, 2008, p. 187 )

As obras surgem de conversas e trocas entre Neville D'Almeida e Hélio Oiticica. Segundo Neville, via Maciel (2009, pp. 295-296), os dois se conheceram em 1967 quando Hélio vê o filme Jardim de Guerra de Neville e de Jorge Mautner. Hélio gostou muito do filme, principalmente pelo uso de pôsteres adotado na estrutura dele por Neville e assim começam a conversar. Nessas conversas Hélio relata que não fazia mais coisas para serem penduradas em parede e comenta como estava ocupando e pensando o espaço. Os dois estavam descontentes com o cinema. "O cinema não é livre, o cinema é arte industrial cativa: isso pode, isso não. O cinema é essa coisa de preconceitos, de censuras, de regras, e a nossa insatisfação com o cinema era enorme. Tínhamos uma mesma ideia, queríamos outro cinema.” (NEVILLE via Maciel 2009, pp.296-297)

Eles queriam um outro cinema, longe do moralismo que tanto os incomodava. Durante a ditadura Neville viaja para Londres e, sem dinheiro, acaba bolando um filme de slides. Quando vai para Nova York conta essa ideia para Hélio, que a aceita imediatamente ."Nasceu assim o cinema de slides, que, em vez de ser o motion pictures, imagens em movimento, é composto de imagens fixas em movimento. Tudo começou aí: o desejo de Hélio de entrar para o cinema e o meu desejo de fazer arte misturando as linguagens." (Neville em entrevista a Maciel 2009, p.298).

Segundo Braga, "ao optarem pelo uso de slides e não pelo filme, Hélio e Neville desnudam essa 'fragmentação do cinetismo', optando por uma experiência de cinema feito de imagens que são marcos discretos e não uma sequência cuja intenção seja criar a ilusão de continuidade com sucessão rápida de imagens”. BRAGA (2007, p.22)

As obras são compostas por uma série de slides, fotografados de capas de disco, de livro, imagens de jornais etc. Desenhados com linhas de cocaína. As obras possuem também trilhas sonoras, e em cada uma das CC são apresentadas algumas proposições aos participadores que se encontram em um ambiente preparado para a vivência da obra. Para cada bloco de experiência Oiticica deixou especificações técnicas em fichas de como montar as obras, que elementos as compõem, as trilhas sonoras e especificações de ambientes tanto para a obra ser apresentada em locais públicos como em locais privados.

Segundo Carneiro (2008, p.188), a projeção dos slides nas CCs dura aproximadamente vinte minutos e tudo começa novamente. Neville fez a edição de som e trilha sonora. E juntos elaboraram o set de cada bloco e "o que seria cenografia de uma tomada de cena de cinema transformou-se no que Hélio denominava 'ambiente' e hoje seria uma 'instalação'." 
(CARNEIRO, 2008, p.190)

As Cosmococas CC1 a CC5 foram concebidas por Hélio e Neville. As outras, de 6 a 9, foram realizadas por Oiticica e outros colaboradores. Nas primeiras cinco Cosmococas, Neville desenhava as carreiras de coca e Hélio as fotografava e montava a série de slides. Segundo Ivana Bentes “os artistas invertem seus papéis habituais: Neville, cineasta, faz desenhos/arranjos/maquiagens in progress sobre imagens preexistentes e Hélio Oiticica, artista plástico, fotografa as sequências”. (BENTES, 2002, p.6-7) ${ }^{48}$

Os desenhos realizados com cocaína eram chamados de "Mancoquilagem". "Maquilagem + Manco Capac, o mítico herói civilizador dos incas que trouxe a folha de coca para seu povo.” (CARNEIRO, 2008, p.190)

O acaso é o que manda na ordem das apresentações das imagens em Cosmococas segundo Oiticica via Braga (2007, p. 81): “acaso como jogo aparece 1 - na hora de tirar as fotografias 2 - na ordem em que ela são colocadas na caixa de laboratório de revelação 3 - na ordem que são colocadas no carrossel.” [...] quero dizer o porque das escolhas e inclusões em COSMOCOCAS : primeiramente, não há nenhuma porque: as escolhas não são escolhidas, mas vieram até mim.” (Oiticica, Hélio. ntbk 2/73, p. 59 via Braga 2007, p. 81)

A cocaína foi, como destaca Neville via Bentes $(2002$, 10), um dos fatores para a demora em apresentar as Cosmococas publicamente, pois "o fato de usar cocaína como material para a maquiagem que efetivamente seria cheirada, num consumo e dissolução literal da obra, criou, segundo Neville d'Almeida, uma impossibilidade total e absoluta de mostrá-la em 1973 [...]”. (BENTES, 2002, 10)

A autora frisa que a cocaína nessa época (1960 -70) estava mais ligada "a um 'momento romântico' ou experimental, ligado a revolta e a contra-cultura e não à economia da droga como mercado/crime organizado em escala mundial e altamente profissionalizado." (BENTES, 2002 p. 10- 11)

Maciel (2009, p.28) lembra que na década de 1970 a cocaína era uma irreverência materializada pelos artistas que não queriam estar associados aos sistemas que dominavam a arte e o cinema; era como um desvio do comportamento instituído.

Hélio Oiticica não chegou a ver as Cosmococas de fato montadas. A primeira montagem pública, segundo Carneiro (2008, p.192), foi em Roterdã, Holanda, em 1992 na

\footnotetext{
${ }^{48}$ BENTES, Ivana. H.O and Cinema-Word in Hélio Oiticica Quasi-Cinemas. Edited by Carlos Basualdo. Kolnischer Kunstverein. New Museum of Contemporary Art. Wexner Center for the Arts. Hatje Cantz Publishers. Germany/New York. 2002. Disponível em: http://webcache.googleusercontent.com/search?q=cache:nd3AiLEIVU4J:www.pos.eco.ufrj.br/docentes/pu blicacoes/ibentes_novo03.doc+\&cd=15\&hl=en\&ct=clnk\&gl=br. Acessado em 10 de abril de 2014.
} 
retrospectiva itinerante de Hélio Oiticica.

\section{Análise das cinco primeiras Cosmococas que fazem parte do Bloco de Experiências in Cosmococa- program in progress}

CC1 Trashicapes (paisagens residuais). Esta obra é a primeira da série Coscomocas e foi inventada em 13 de março de 1973. Nela vemos projetada e multiplicada a imagem do cineasta Luís Buñuel na capa da revista New York Magazine "com uma navalha sobreposta à linha branca que corta o olho do cineasta , como na imagem do olho cortado em seu filme $O$ cão andaluz." (MACIEL, 2009, p. 289)

Aparecem Ainda outras fotos com desenhos de cocaína projetados sobre duas paredes opostas nesta obra. Segundo Carneiro aparecem:

série do poster preto e branco de Luis Fernando, ator e amigo de Hélio, vestindo Parangolé 30 Capa $23 M^{\prime}$ Way Ke , da série Parangolé realizada em Nova York. A série da capa do álbum de Frank Zappa: Weasel Ripped My Flesh (doninhas rasgaram minha carne): um desenho do rosto de um rapaz "certinho" arranhado por uma doninha que ele segura como se fosse uma máquina de barbear. Um foto de Neville, ao telefone com camiseta listrada. (CARNEIRO, 2008, p.194)

A autora também destaca que aparecem muitos objetos nos slides tais como: facas, navalhas, cinzeiros, espelho redondo, canudos de dólar, lata de filme e acompanhados de trilha sonora, contendo fragmentos "do baião de Luís Gonzaga, trechos de Pífaros de Caruaru, de Stockhausen, de Hendrix, de sons da rua". (CARNEIRO, 2008, p. 194)

Nessas obras os participantes são convidados a lixar suas unhas e podem ficar acomodados em colchões e travesseiros.

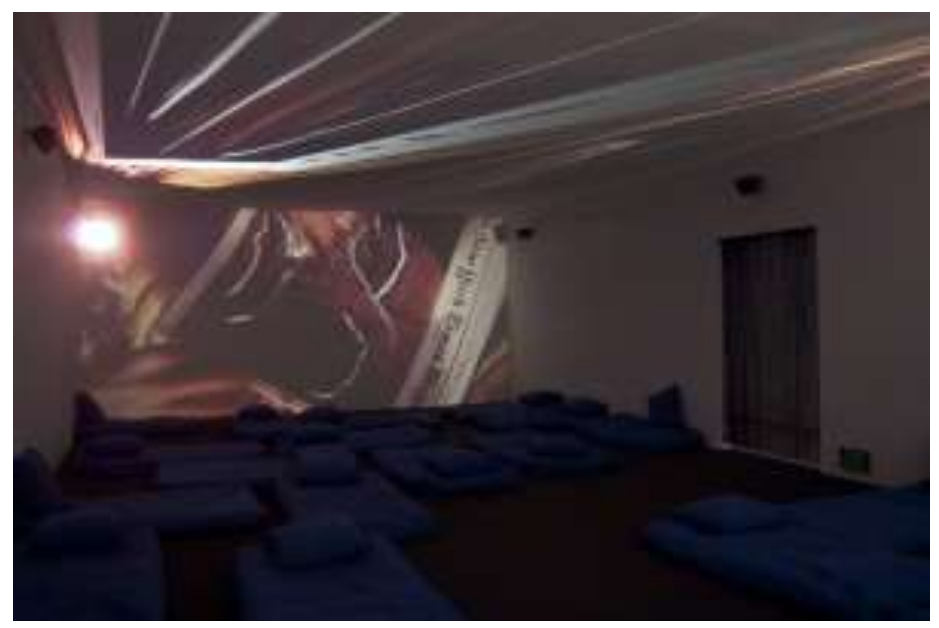

Figura 46: Helio Oiticica e Neville de Almeida. CC1 Trashicapes. 1973

Fonte: http://www.hirshhorn.si.edu/collection/resource-centre/\#detail=/bio/press-images-suprasensorialexperiments-in-light-color-and-space/\&collection=resource-centre 
CC2 Onobject, 12 de agosto de 1973

Nesta obra as imagens fotografadas com desenhos de cocaína e projetadas agora são segundo Oiticica via site do Itau cultural ${ }^{49}$ : dos livros: de Yoko Ono/ Grapefruit: a book of instructions, Heidegger, What's a Thing, Charles Manson Your Children. Carneiro (2008, p.194) lembra que Charles Manson foi o mandante dos assassinatos de Sharon Tate e hóspedes de sua casa. Esse crime ocorreu em 1969 e ficou na mídia até 1970. O livro Your Children "transcreve integralmente a declaração processual do acusado". (CARNEIRO, 2008, p. 194)

Ainda segundo a autora a trilha sonora dessa obra vem do álbum duplo Fly de Yoko Ono.

Nesta obra os participantes podem dançar e pular. O chão é forrado de espuma coberta de tecido branco e na sala ocorrem quatro projeções nas paredes. Encontram-se também nesta sala objetos de espuma como bolas, cubos, cones, cilindros.

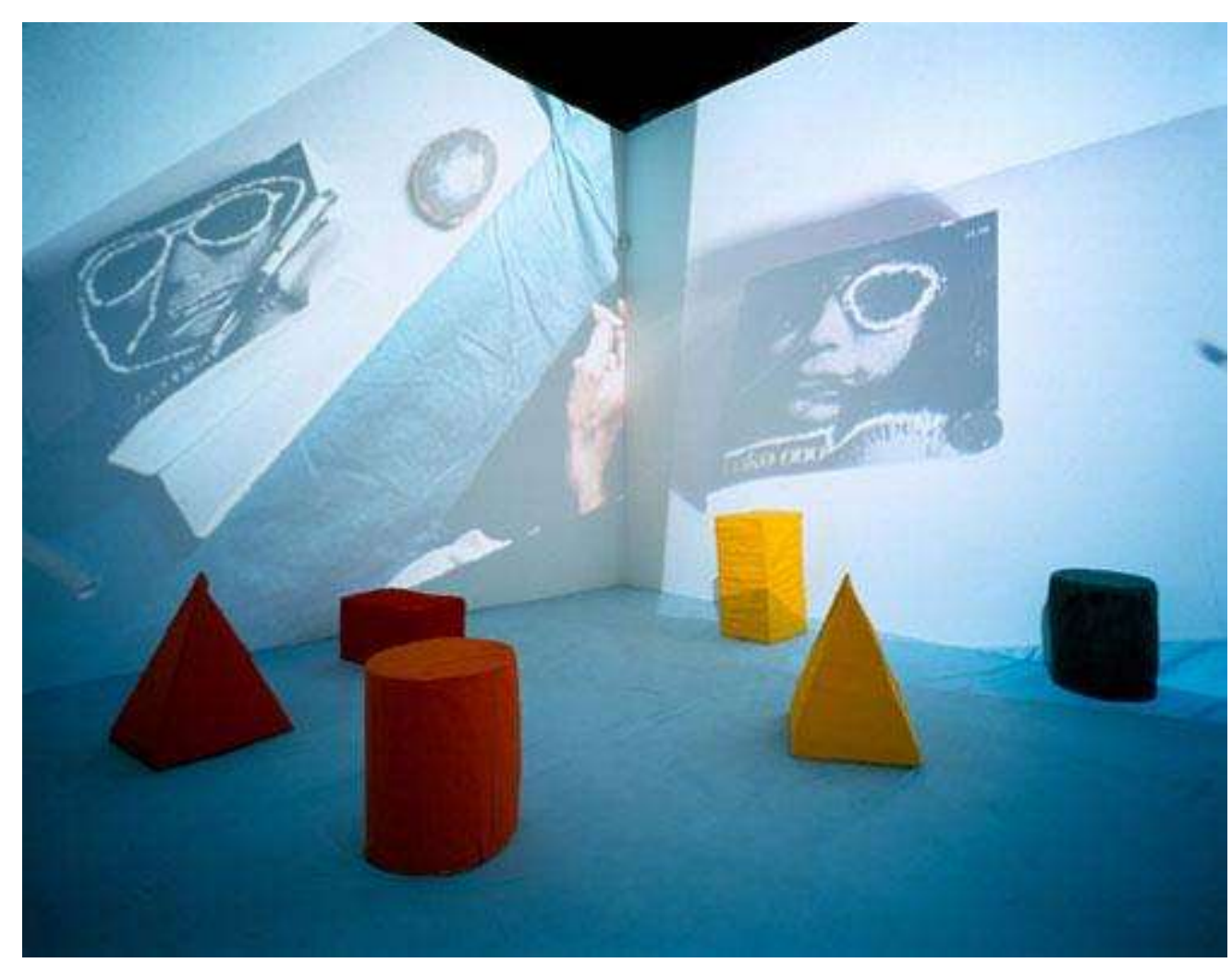

Figura 47: Helio Oiticica e Neville de Almeida. CC2 Onobject. 1973

Fonte: http://www.artadoo.com/en/display/work/title/cc2-onobject-cosmococa-programa-in-progress$19732004 / \mathrm{id} / 236796$ 
CC3 Maileryn 16 de agosto de 1973.

Nesta obra aparecem nas quatro paredes e no teto imagens projetadas que incluem:

fotografia de Marilyn (por Mailer) envolta por celofane; cocaína e acessórios; nota de US\$ 5 ; P31 Capa 24 Parangolé (NY, 1972), entre outras. As projeções acontecem simultaneamente nas quatro paredes e no teto. Os participantes estão deitados no chão coberto de vinil, sobre dunas de areia, e ficam rolando. Recebem balões para assoprar, junto com apitos. ${ }^{50}$

Neste ambiente encontram-se bolas amarelas e laranja que podem ser jogadas e as pessoas devem entrar descalças. Segundo Carneiro a trilha sonora fica a cargo da cantora popular peruana Yma Sumac, com “canções referentes aos rituais incaicos". (CARNEIRO 2008, p. 195)

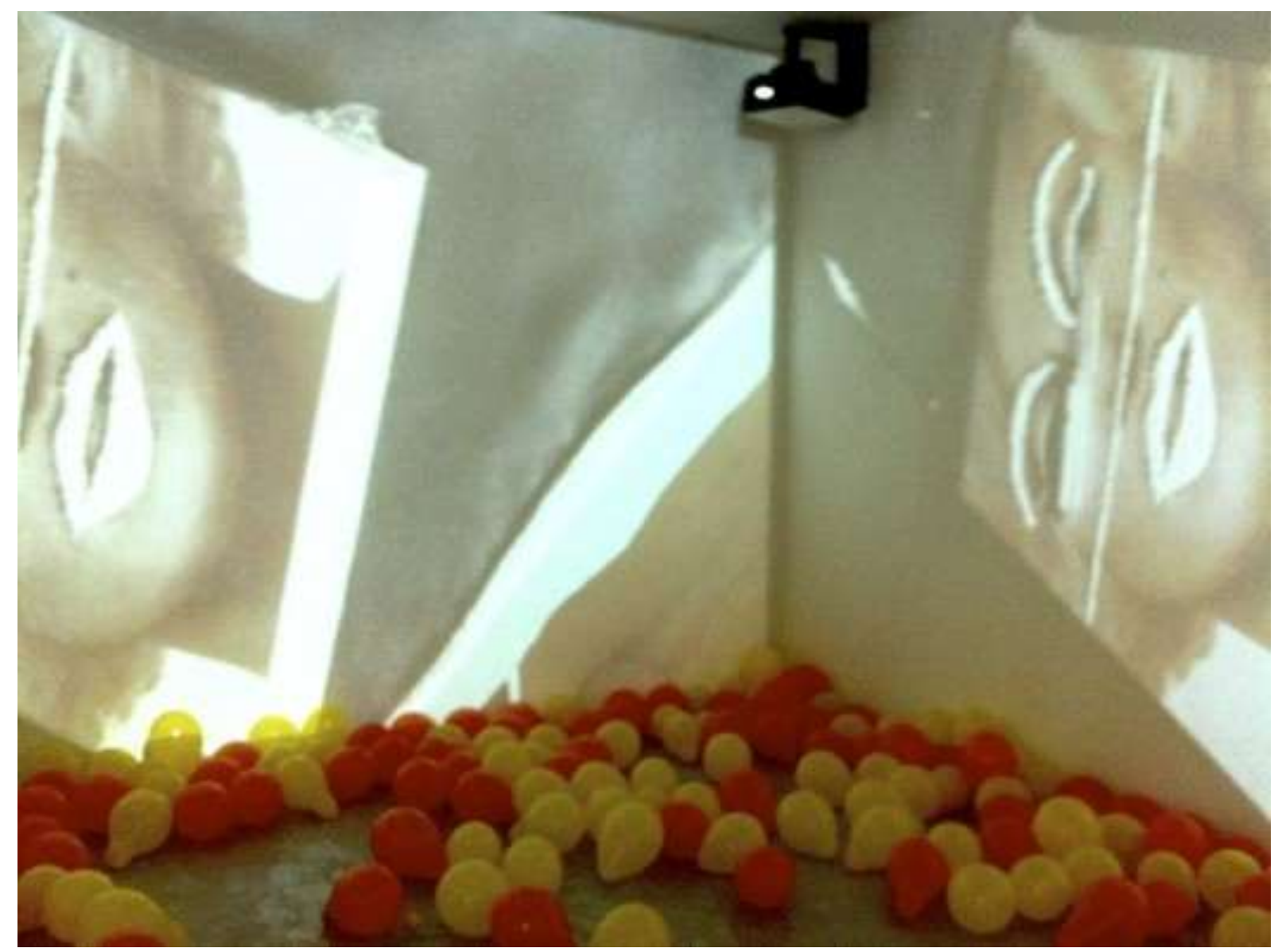

Figura 48: Helio Oiticica e Neville de Almeida. CC3 Maileryn. 1973

Fonte: http://now-here-this.timeout.com/2013/10/17/rieze-london-2013/

\footnotetext{
50 Informação reirada de: http://www.itaucultural.org.br/aplicexternas/enciclopedia/ho/index.cfm?fuseaction=documentos\&cod=54 $\underline{1 \& \text { tipo }=2}$, Acessado em 10 de maio de 2014
} 


\section{CC4 Nocagions de 24 de agosto de 1973}

As projeções em duas paredes podem ser visualizadas pelo participador fora ou dentro de uma piscina que se encontra no espaço expositivo. Nesta obra é projetado a capa do livro de John cage intitulado Nocagions. Segundo site do Itaú cultural, Oiticica dedica esta obra aos poetas concretos Augusto e Haroldo de Campos e "salienta o uso e mistura de várias linguagens sem se limitar a nenhuma em particular: "música, poesia, objeto transformável, quasi-cinema, experiência cinética, multi-mídia etc".(site do Itaú Cultural) ${ }^{51}$

Segundo Carneiro (2008, p. 195), a trilha sonora é iniciada por Beethoven e continua com excerto da peça de Cage com piano preparado.

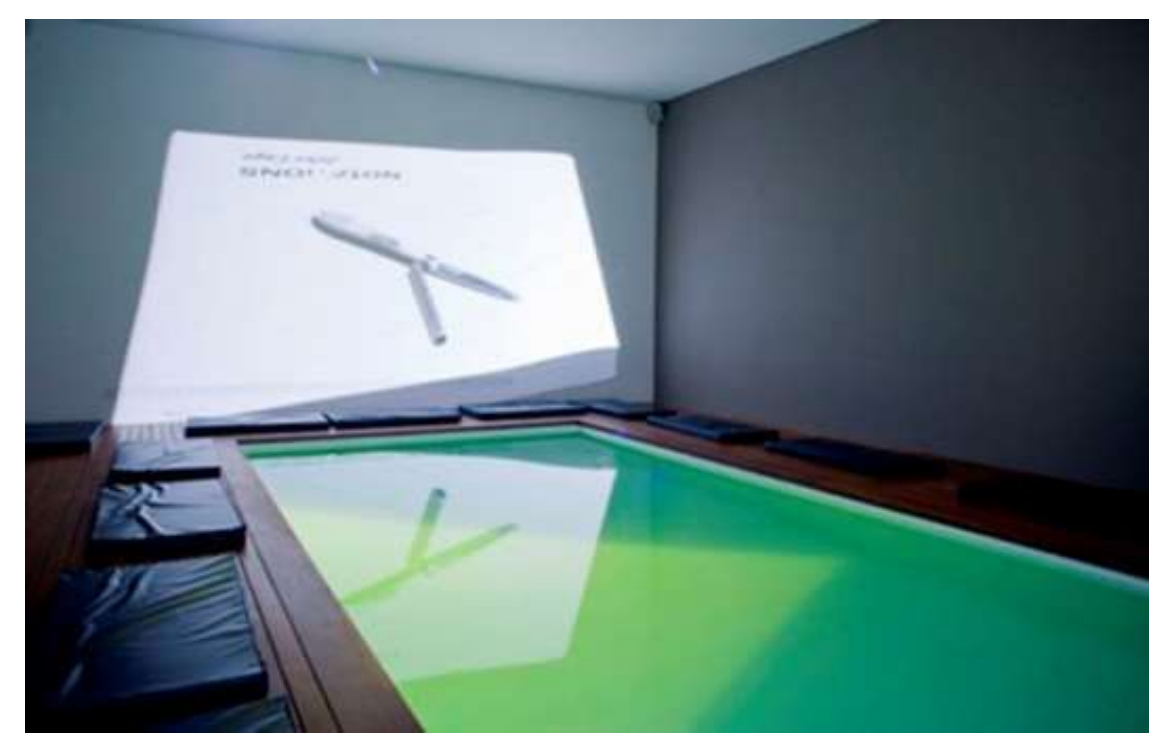

Figura 49: Helio Oiticica e Neville de Almeida. CC4 Nocagions. 1973

Fonte: http://arteref.com/instalacao/instituto-inhotim-programacao/

CC5 Hendrix- War, de 26 de agosto de 1973.

Esta obra é um tributo a Hendrix que nasceu de um encanto de Hélio por Hendrix. (BENTES, 2002, p. 13)

Os slides projetam em todas as paredes e no teto do espaço expositivo imagens da capa de disco War Heroes, de Jimi Hendrix, que foi lançado segundo Carneiro (2008, p.196) postumamente em 1972. A capa do disco em que se vê o rosto de Hendrix foi desenhada com linhas de cocaína, que "sugerem borboletas ocultando e revelando os traços do rosto em outro

51

http://www.itaucultural.org.br/aplicexternas/enciclopedia/ho/index.cfm?fuseaction=documentos\&cod=54

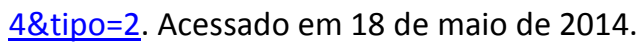


plano", ele afirma. Bentes acrescenta que "o rastro-coca sobre o rosto de Hendrix na capa do disco o transforma numa máscara monumental, um ícone "totêmico-negro-índio". (BENTES 2002, p.14)

$\mathrm{Na}$ máscara feita com coca em Hendrix nessa capa de disco observa-se também, segundo Bentes (2002, p.14), o elemento fogo que surge numa caixa de fósforo com o logo da coca-cola.

A trilha sonora é de Jimi Hendrix. Os espectadores podem ficar em redes, que Carneiro (2008, p.196) diz aludirem ao nordeste do Brasil.

No site do Itaú Cultural ${ }^{52}$ encontramos nas cópias das folhas datilografados pelo artista informações sobre as suas instruções para a obra, inclusive que os participantes podem ocupar as redes que estão espalhadas pelo espaço expositivo, e que 34 slides fazem parte dela. Ainda nessas instruções, Hélio especifica como deveria ser a instalação, em dois tipos de espaço: num deles o artista desenvolve uma forma de montagem para a performance pública e noutro, para performance privada.

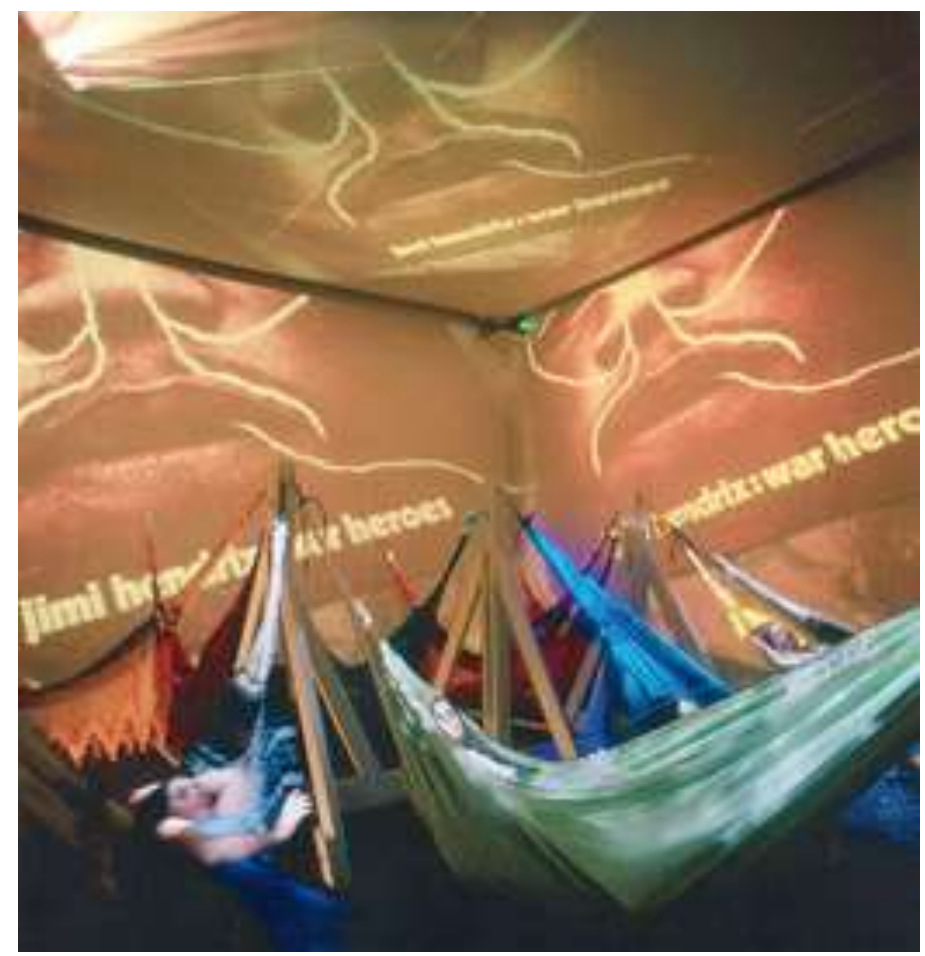

Figura 50: Helio Oiticica e Neville de Almeida.. CC5 Hendrix- War.1973

Fonte: http://www.artecapital.net/entrevista-155-neville-d-almeida 


\section{Douglas Gordon}

\subsubsection{Hour Psycho (1993)}

Douglas Gordon ${ }^{53}$ trabalha com apropriações de filmes. O artista escolhe se apropriar de filmes muito conhecidos do século XX e que já povoam o imaginário coletivo, cultural. Apresenta os filmes de maneira diferente do original, principalmente modificando o tempo de apresentação das imagens. Em 24 Hour Psycho se apropria de Psicose, de Alfred Hitchcock, de 109 minutos, e o filme passa a ter 24 horas na videoinstalação. O tempo dilatado causa modificações na percepção das imagens e modifica nossa experiência habitual do cinema. A plasticidade da imagem é priorizada, ao invés da narrativa. De fato, os espectadores não conseguem acompanhar a narrativa e o que fica em evidência é a exposição dos quadros expostos do filme. Na instalação a tela está suspensa e é possível ver o trabalho pela frente e pelo verso da mesma. Gordon retira o som do trabalho e ficam apenas as imagens em exposição.

Essa obra de Douglas Gordon utiliza-se, como foi dito, de apropriações de imagens, uma prática recorrente na arte contemporânea. Para Danto, a apropriação foi a maior contribuição da década de 70, pois "a apropriação das imagens com sentido e identidade estabelecidos, conferindo-lhes um sentido e identidade novos". DANTO (2006, p.19) Segundo ainda o autor, tudo poderia ser apropriado, de forma que não se teria uma forma particular de arte, um estilo, e nem um modelo visual melhor que outro; as obras de arte não podem ser definidas pelas suas qualidades visuais encerrando assim o paradigma da arte moderna. As obras requerem o corpo para elaboração de sensações, sentido, e não apenas a visão. Os artistas segundo Danto, (2006, p.18), “possuíam toda a herança da história da arte com a qual trabalhar, inclusive a história da avant-garde que colocou à sua disposição as fantásticas possibilidades que a avant-garde havia desenvolvido e que o modernismo tudo fez para reprimir". Para Bourriaud (2009, p.22), a apropriação acontece na história, mas na arte inicia-se com Duchamp, a partir da escolha do objeto. A escolha a partir do olhar do artista é a operação artística. O artista de nossa análise Douglas Gordon, não cria nenhuma imagem nova, ele escolhe, utiliza-se de um filme já existente, industrial e que povoa o imaginário. Nesse sentido, aproximamo-nos de uma característica da arte contemporânea, que não tem nada contra o passado e não se sente obrigada a se libertar dele e nem adota a ideia de

\footnotetext{
${ }^{53}$ Douglas Dordon (1966) artista escocês, trabalha principalmente com videoinstalações que em sua grande apropria-se de filmes clássicos do século XX.
} 
progresso como na arte moderna, em suas narrativas progressistas. A arte contemporânea trabalha com a arte disponível para usá-la. Os artistas contemporâneos não veem o museu (neste caso o artista não vê o filme) como arte morta, mas como um arsenal de imagens e pensamentos para opções artísticas. Segundo Bourriaud (2009), a arte se apropria e se inspira não somente da história da própria arte e seus modos de procedimentos, mas também da cultura em geral. Em Bourriaud (2009, p.14): "trata-se de tomar todos os códigos da cultura, todas as formas concretas da vida cotidiana, todas as obras do patrimônio mundial, e colocálas em funcionamento". Outra característica da arte contemporânea é a participação do espectador não só com seu olhar para a obra, mas com todo o seu corpo. Na obra de Gordon os espectadores são convidados a andar, observar, voltar ao trabalho, já que não é possível assisti-lo por completo.

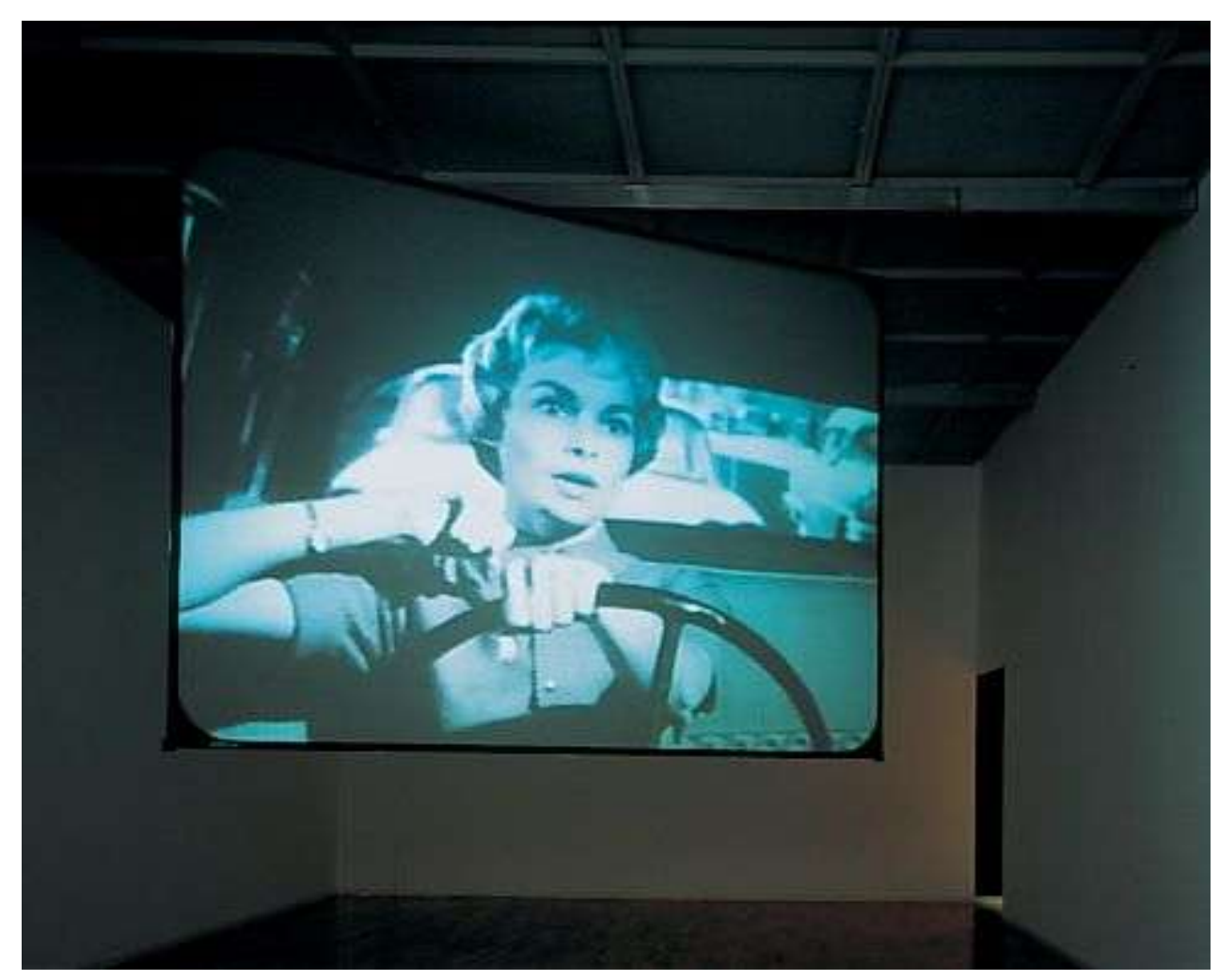

Figura 51: Douglas Gordon. 24 Hour Psycho 1993

Fonte: http://pictify.com/144743/douglas-gordon-24-hour-psycho 


\subsection{Descrição de obras}

\subsubsection{Percurso}

Como relatado logo na introdução desta dissertação, o motivo inicial de realizarmos esta pesquisa se deu pela produção de obras de nossa autoria, realizadas um pouco antes do início do mestrado e que serão descritas nesta parte da dissertação.

A partir da primeira obra que faz parte de uma série em andamento, Work in progress, e que se intitula Autorretrato com duração e sons variáveis, passamos a pensar em várias questões relacionadas às telas e aos materiais que poderiam servir para tal fim. Nela, trabalhamos principalmente a relação projeção e superfície de projeção diferente da tela branca ou parede. Para a exibição desse trabalho usamos uma tela de gelo, que potencializa, expressa as ideias que buscamos concretizar.

Pesquisamos e realizamos obras com imagens em movimento desde 2006 e sempre nos chamava a atenção a projeção de imagens sobre diversas superfícies.

Pesquisávamos a projeção em móveis, espelhos, em nossos corpos, almofadas, janelas etc. nos parecia muito interessante a maneira como a projeção era aí visualizada. Embora o interesse tenha iniciado nesta época, foi a partir de 2011(ano anterior a nossa entrada no mestrado) que passamos a desenvolver performances para a câmera e sentimos necessidade de apresentar as imagens que captávamos sobre superfícies diferenciadas de projeção. Só assim conseguimos potencializar significados, gerar relações espaciais que nos interessavam. Apenas trabalhar com imagens em movimento não dava conta do que pretendíamos. A forma de exibição e a tela eram muito importantes. Em 2011 iniciamos a série referida acima (que continua sendo produzida) de autorretratos projetados em telas de gelo. A superfície de projeção foi procurada, pesquisada, para expressar a ideia de efemeridade que já estava contida no propósito de trabalhar com série, mas a mudança e a instabilidade de tal superfície eram realmente o que potencializava essa ideia. A nosso ver, aí também se criava uma relação entre imagens em movimento e pintura, tanto pela temática, autorretratos, como pela fisicalidade da tela, por ser efetivamente uma pintura em movimento, já que, com o decorrer do tempo, ela se transforma (a tela de gelo é constituída de água e tinta congelada que vai se modificando gradativamente. Essa obra será descrita com detalhes mais adiante).

Outros trabalhos que estávamos realizando ainda nessa época eram também performances para a câmera, mas apresentadas em monitor ou projeção sobre paredes (exibição tradicional). 
O que havia em comum na maioria dos trabalhos era o uso de nosso corpo que através de movimentos, de atos e da relação criada com os objetos que aparecem nos vídeos, ia modificando, mostrando, enquadrando, controlando o que ficava visível. Por exemplo, o ato de abrir e fechar janelas e assim controlar a luz do ambiente e revelar ou não o que havia no local onde nos encontrávamos, ou andar segurando um espelho e assim enquadrar imagens e modificar a paisagem. Estas obras comentadas ,aqui, serão retomadas na parte descrição de obras nessa dissertação e são intituladas Janelas e Sem Título. Sem Título é composta de uma série de três vídeos.

Aqui nos limitaremos apenas a descrever e comentar a relação das obras com a pesquisa realizada. Concordamos com Duchamp quando ele diz que as leituras das obras são diversas e que existe uma diferença entre o que o artista pensou, o que efetivamente realizou, e o que o público irá concluir, observar e contribuir, também por suas leituras, entendimentos etc. Nesse sentido, concordamos com o "coeficiente de arte" de Duchamp. Nas palavras dele:

No ato criador, o artista passa da intenção à realização, através de uma cadeia de reações totalmente subjetivas. Sua luta pela realização é uma série de esforços, sofrimentos, satisfações, recusas, decisões que também não podem e não devem ser totalmente conscientes, pelo menos no plano estético.

O resultado deste conflito é uma diferença entre a intenção e a sua realização, uma diferença de que o artista não tem consciência.

Por conseguinte, na cadeia de reações que acompanham o ato criador falta um elo. Esta falha que representa a inabilidade do artista em expressar integralmente a sua intenção; esta diferença entre o que quis realizar e o que na verdade realizou é o "coeficiente artístico" pessoal contido na sua obra de arte. Em outras palavras, o "coeficiente artístico" pessoal é como que uma relação aritmética entre o que permanece inexpresso embora intencionado, e o que é expresso nãointencionalmente [...].O ato criador toma outro aspecto quando o espectador experimenta o fenômeno da transmutação; pela transformação da matéria inerte numa obra de arte, uma transubstanciado real processou-se, e o papel do público é o de determinar qual o peso da obra de arte na balança estética.

Resumindo, o ato criador não é executado pelo artista sozinho; o público estabelece o contato entre a obra de arte e o mundo exterior, decifrando e interpretando suas qualidades intrínsecas e, desta forma, acrescenta sua contribuição ao ato criador. (Duchamp em BATTOCK 1975. p. 73-74) ${ }^{54}$

Importante, neste momento, é deixar claro que não pretendemos esgotar o significado de cada trabalho, por considerarmos que falar da própria produção é uma tarefa bastante delicada e complexa, até porque muita coisa escapa da racionalidade. Por isso, vamos apenas descrever os trabalhos e as relações mais diretas com o assunto pesquisado.

Durante nossa produção inicial (antes da escolha definitiva do tema desta dissertação), pretendíamos em um primeiro momento pesquisar sobre o uso de espelhos no campo das artes, já que em alguns trabalhos realizados até aquele momento, o espelho era um elemento

\footnotetext{
${ }^{54}$ DUCHAMP, Marcel. “O ato criador”. In: Gregory Battcock (org.). A nova arte. São Paulo: Perspectiva,
} 1975. p. $73-74$ 
recorrente. Mas, ao mesmo tempo, autorretratos também nos interessavam. Embora a temática de autorretratos tivesse ligação com o uso de espelhos em algumas obras que estávamos realizando, focar o estudo nesse material especificamente não dava conta de toda a produção.

Persistia, ao mesmo tempo, a vontade mais antiga de pesquisar superfícies de projeção e modos de exibição das imagens em movimento. Passamos então a ler sobre cinema expandido, cinema de exposição, e a pesquisar artistas que também se interessavam em exibir imagens sobre superfícies diferenciadas. Obras que se afastavam da exibição tradicional de apresentação de imagens em movimento se encontravam frequentemente em espaços de arte, aproximando-se assim ao tema de cinema exposição. Unindo nossa vontade de continuar produzindo obras dentro dessa pesquisa, juntamente com leituras de textos sobre os assuntos comentados, elaboramos um projeto que, por sua vez, gerou esta dissertação

$\mathrm{Na}$ maioria das obras descritas aqui, como dito anteriormente, nosso corpo foi utilizado em confronto com a câmera, mas recursos de pós-produção também nelas estão presentes. Os procedimentos que iremos descrever sobre a realização dos nossos trabalhos são um pouco diferentes do que acontecia por volta de 1960-70, principalmente na produção artística de 1970 no Brasil (ver capitulo 2 tópico 2.9 desta dissertação) ${ }^{55}$. Nesse período, os artistas realizavam obras de performances para a câmera, mas dificilmente editavam essas imagens, principalmente porque nesse contexto as tecnologias não estavam facilmente disponíveis aos artistas. Nos trabalhos que realizamos a edição é fortemente usada, o que foi facilitado pelos meios digitais. Como apontado por Santaella (2008, p. 300) e em nossa dissertação no capitulo 2 parte 2.9, os corpos são ainda analógicos quando registrados por cinema, foto ou vídeo, ou seja, por câmeras, pois, neste caso, são mantidas no registro as características espaciais e temporais e, quando são transformados em pixels, tais corpos podem sofrer diversas modificações. Em nossos trabalhos, o corpo passa por câmeras de registro que mantêm, como afirmado por Santaella, as qualidades espaciais e temporais, mas logo após o registro das performances, em vídeo, trabalhamos a imagem de nosso corpo com diversas sobreposições, transparências e fusões. As imagens são apresentadas em diversas janelas, criando assim modificações nas qualidades temporais e espaciais captadas pela câmera. Nosso corpo passa a ser duplo, sobreposto, os espaços onde se insere são ambíguos pelo uso de diversas camadas de imagens e fusões. Procuramos, dessa forma, elaborar um trabalho que possibilita leituras espaciais e temporais simultâneas.

\footnotetext{
${ }^{55}$ Para um melhor entendimento do início da vídeoarte brasileira, consultar. MACHADO, Arlindo (org.). Made in Brasil. Três décadas do vídeo brasileiro. São Paulo: Itaú Cultural, 2003.
} 
Resumindo, trabalhamos em algumas obras com apresentação das imagens sobre superfícies de projeção diferentes e, em outras, usamos diversas imagens sobrepostas e com fusões em multijanelas dentro de uma única tela.

Também transformamos algumas dessas performances que realizamos para as câmeras em instalações que dialogam com os corpos dos espectadores, pois, sendo obras espaciais, requerem movimentos corporais ao redor da obra ou, se assim preferirem, alguma alteração na projeção pela inserção dos corpos na frente da projeção ou nas paredes do espaço, criando sombras. Alguns trabalhos também pressupõem que o espectador use sua percepção e complete partes das imagens faltantes, como em Pintura em Atos e Autorretrato com duração e sons variáveis. Em Pintura em Atos (que será descrita posteriormente) a superfície de projeção (folha de eucatex perfurada) possui furos, deixando a imagem projetada incompleta tanto quando vista na folha de eucatex quanto na parede atrás da superfície de eucatex. $\mathrm{Na}$ série Autorretrato com duração e sons variáveis, por ser uma série de obras efêmeras e que se modificam (formalmente) no decorrer do tempo, as leituras são diferenciadas e dependem do momento de contato com a obra. Se o espectador entra no espaço expositivo no início da apresentação da obra, vê a imagem com pouca deformação; se entra posteriormente, vê esse autorretrato fragmentado, distorcido e com partes faltantes as quais pode completar. $\mathrm{O}$ espectador completa o todo pelo que resta da imagem e da obra.

\section{Descrição das obras e suas ligações com a pesquisa}

\subsubsection{Série: Autorretrato com duração e sons variáveis}

Esta série é composta de autorretratos (de nossa autoria) em vídeos projetados sobre uma ou mais telas de gelo. A série, até o momento, compreende quatro obras. As telas são produzidas com água e tinta congelada.

Os vídeos ficam projetados em looping até o derretimento total das telas. Assim que isso acontece, a projeção é desligada, retomando-se sua exibição após a troca da (s) tela(s).

As telas de gelo são apresentadas apoiadas sobre uma caixa preparada, que possui: furos para escoamento de água e tecido escuro em seu fundo para que a visualização seja mais nítida apenas nas telas de gelo enquanto ocorre o derretimento.

A obra I da série também possui uma versão em que a tela fica apoiada sobre um suporte bíblico (como visto na figura 53). Com esse apoio a tela vai adquirindo sulcos e deforma mais, pois vai tomando a forma do suporte em que foi apoiada. 
As telas de gelo das obras da série, juntamente com o recipiente abaixo delas (aproximadamente, 1,5 m) durante a exibição, geram ao vivo os sons que marcam a passagem do tempo. Cada obra da série será descrita mais detalhadamente nos próximos tópicos.

Com base na pesquisa realizada, vamos inserir esta série no estudo do chamado cinema de exposição (ver capitulo 3) isto é, nas pesquisas contemporâneas de exibição de imagens em movimento que utilizam do dispositivo do cinema mas que modifiquem o uso padrão de exibição que ficou mais relacionado a este dispositivo: tela única retangular gigantesca que serve para apresentação de diversos filmes, uma projeção (escondida) de imagens que vêm detrás da cabeça dos espectadores, sala escura onde imagens são apresentadas para espectadores sentados etc.

A série de autorretratos projetados em telas de gelo, por ter a tela e seu material como principal modificação do dispositivo padrão de cinema de sala de exibição, vai ao encontro de uma de nossas hipóteses: a de que as alterações de tela mais frequentes na contemporaneidade retomam procedimentos de vanguarda das artes visuais, principalmente no uso ampliado de diversos materiais neste campo. Esta obra, a nosso ver retoma procedimentos de artes visuais no que se refere ao uso de suportes e materiais variados. O uso e expansão de suportes e materiais diversificados no campo das artes visuais podem ser visto no capítulo 1 desta dissertação. O estudo abarca um panorama que vai desde o uso tradicional da tela e tinta aos seus usos diversificados, estendendo-se ao uso de objetos industriais, corpo humano e seus desdobramentos, como sua relação com as imagens em movimento, aproximando-se e focando as performances para a câmera. Isso a nosso ver, retorna a apresentação em telas que posteriormente, leva a uma expansão em múltiplas projeções e de diversificados modos de exibição destas imagens (performances para a câmera).

Esta expansão de materiais e suportes que comentamos está ligada, nesta obra que estamos estudando, de duas formas: 1) ao uso de materiais (gelo como superfície de exibição) mais ligados às artes visuais, e, portanto diferentes do padrão de exibição do audiovisual (tela de cinema de sala de exibição ou monitor); 2) ao uso do corpo do artista como instrumento, como suporte nessa expansão das artes visuais e a relação deste corpo com as imagens em movimento, como as performances para a câmera, que foram um dos desdobramentos da performance nas artes visuais.

Esta expansão de materiais e suportes que comentamos está ligada, nesta obra que estamos estudando, de duas formas: 1) ao uso de materiais (gelo como superfície de exibição) 
mais ligados às artes visuais, e, portanto diferentes do padrão de exibição do audiovisual (tela de cinema de sala de exibição ou monitor); 2) ao uso do corpo do artista como instrumento, como suporte nessa expansão das artes visuais e a relação deste corpo com as imagens em movimento, como as performances para a câmera, que foram um dos desdobramentos da performance nas artes visuais.

Em relação ainda à expansão de suportes e assim como já comentado, ao uso do corpo do artista, esta obra também se insere na classificação feita por Santaellla (ver parte capítulo 2 tópico 2.9). A autora tenta mapear as produções contemporâneas que usam o corpo, dividindo-as em duas principais tendências: refrações do corpo e memórias do corpo. Nessa última categoria, afirma que os artistas pretendem armazenar, registrar o corpo. De nossa parte, houve a preocupação de registrar a fisicalidade de nosso corpo, através do vídeo, portanto, esta obra está inserida na categoria estudada. Porém, também ressaltamos que o corpo registrado pelo vídeo passa por distorções até seu total apagamento durante a exibição efêmera na tela de gelo. Nossa intenção foi mostrar um corpo distorcido, refratado, ligando este trabalho também à categoria refrações do corpo, de Santaella.

A projeção de um corpo nessa superfície efêmera (tela de gelo) faz com que ele pareça estar derretendo, deformando-se. A tela vai criando no decorrer do tempo formas orgânicas, sulcos, buracos, trincas, tinta escorrida, efeitos que modificam a visualização do que está sendo projetado (autorretrato de nossa autoria).

Esta série, em nosso entender, é uma fusão entre pintura, escultura, performance, cinema (escrita do movimento) e instalação. Como relatado, a tela vai sofrendo alterações. No início da apresentação ela é lisa e regular; é uma pintura fixa (a tela de gelo é feita de água e tinta congelada), mas, no decorrer da exibição na tela, vai adquirindo formas, sulcos, trincas concavidades, ocos (ligando-se à escultura); e suas manchas brancas, mais precisas inicialmente, começam a se movimentar, produzindo uma pintura móvel e modificando a visualização do que é projetado.

Essas obras da série estão inseridas também dentro da classificação telas efêmeras que fizemos no capítulo 3. Fizemos tal classificação numa tentativa de organizar e compreender melhor as características mais ressaltadas das telas. A opção por tela efêmera foi sugerida nessa obra por observarmos que nem sempre ela está disponível no espaço expositivo (como a tela de cinema de sala ou monitor).

Por fazer uso de superfície de exibição efêmera e por ser uma obra com a ideia de série, nela prevalece o inacabamento, o work in progress como característica. Assim, liga-se 
também às pesquisas de cinema expandido/panorâmico (vistas no capítulo 2 parte 2.8), em que os artistas e cineastas procuram criar obras abertas, sempre em processo. Diferentes das obras audiovisuais tradicionais, acabadas, fechadas numa versão permanente para posterior projeção em máquinas ou formas de exibição tradicionais.

As apresentações das obras da série de Autorretratos acontecem ao vivo. Elas nunca são repetidas igualmente. A cada apresentação, a duração da obra, a visualização dos autorretratos e também os sons são diferentes; as telas são refeitas, elas passam por um preparo, semelhante ao preparo que o pintor realiza em sua tela (como vimos no capítulo 1) para receber tinta, com a diferença de que esta obra recebe uma pintura de luz.

\section{Descrição de cada obra da série:}

\section{Autorretrato com duração e sons variáveis I/ ano 2011}

A obra número I desta série, foi realizada em 2011 e foi exposta no $39^{\circ}$ Salão de Arte Contemporânea Luiz Sacilotto, no mesmo ano. O vídeo que apresenta nossa imagem sentada em uma cama, onde realizamos poucos movimentos como os de piscar, mover levemente a cabeça, é projetado em uma tela de gelo. Esta obra da série teve dois modos de exibição da tela. Em um deles ela foi apresentada apoiada em suporte bíblico e em outro a tela foi apoiada na caixa preparada que comentamos acima. 


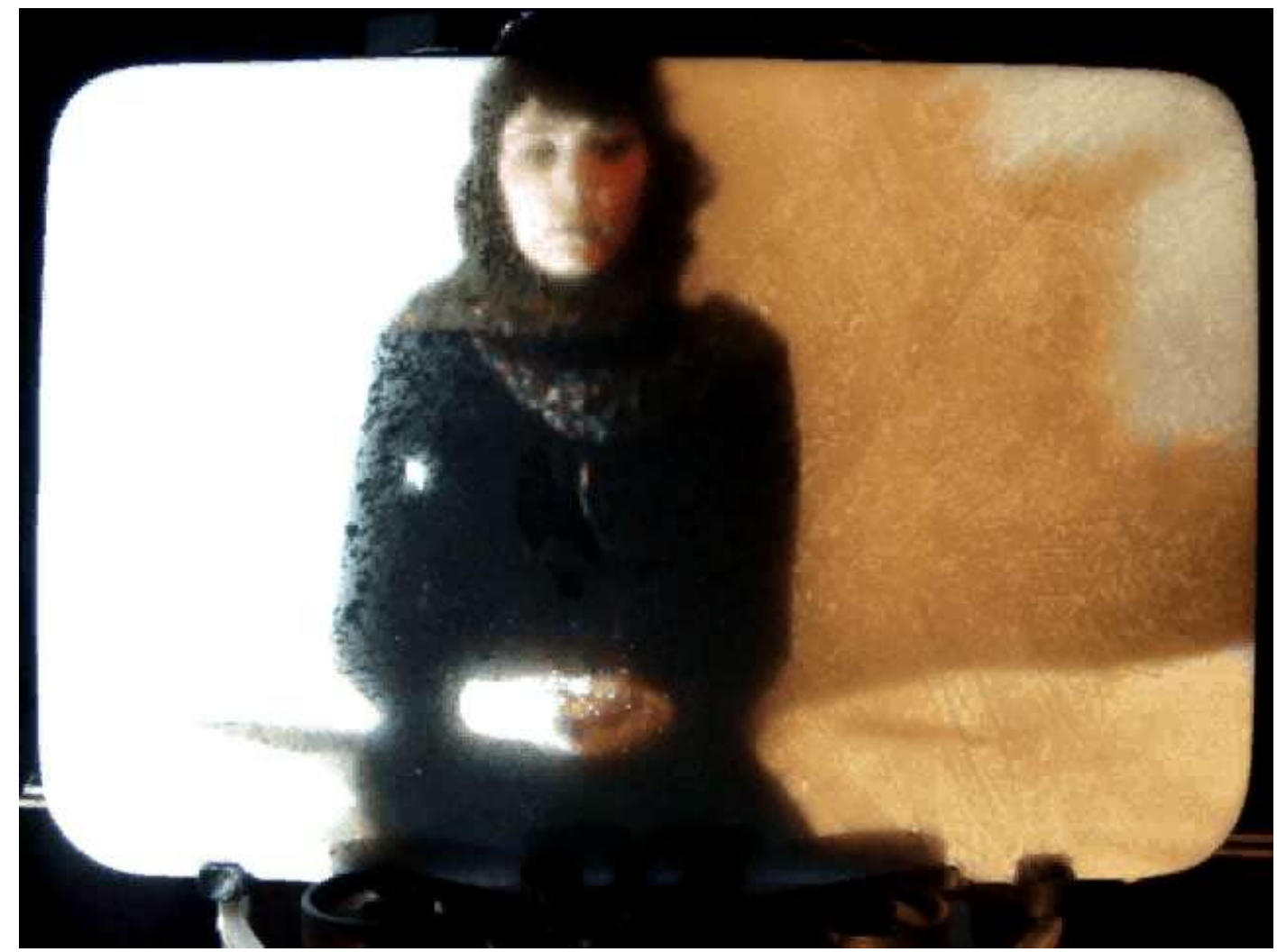

Figura 52: Viviane Vallades. Autorretrato com duração e sons variáveis I.2011

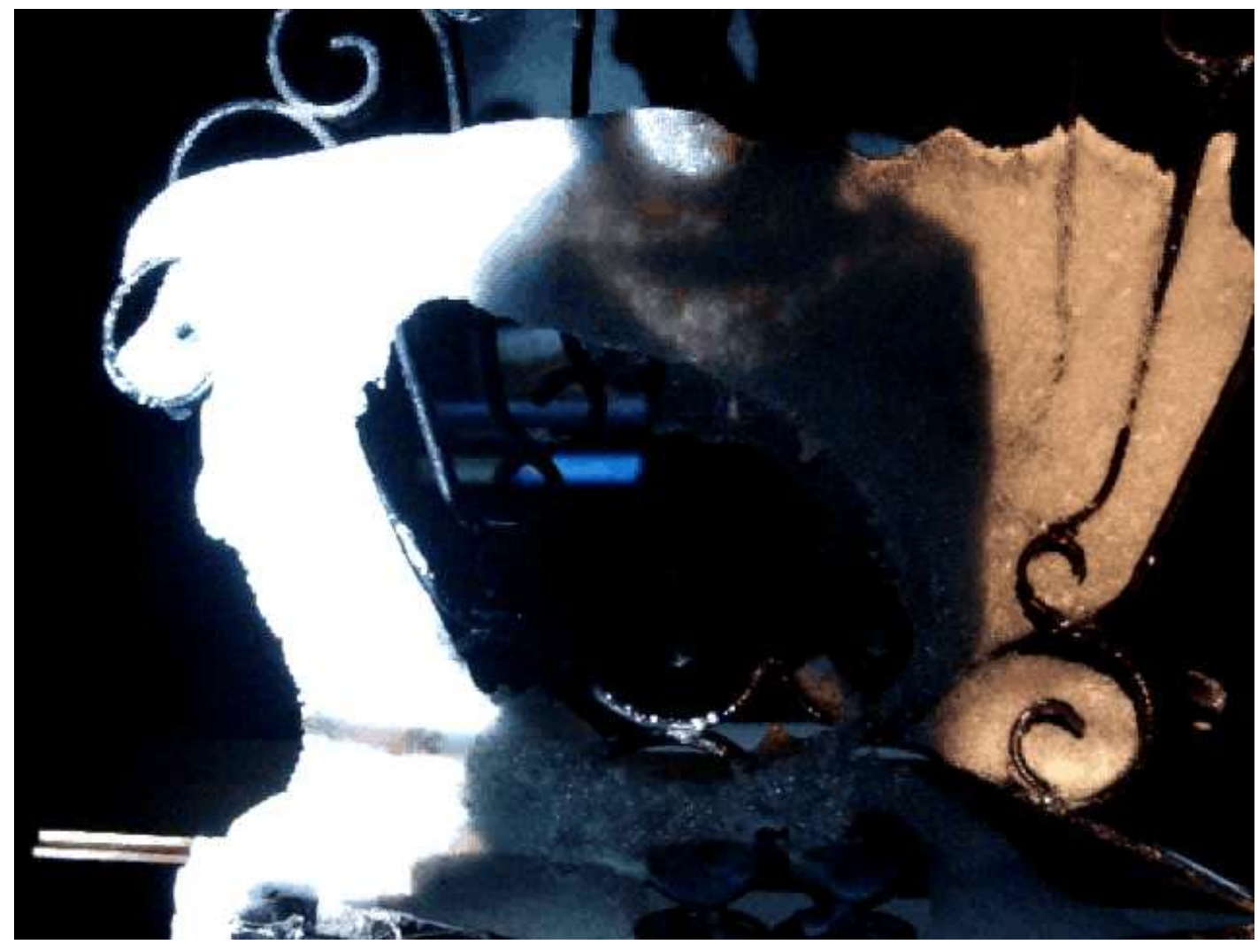

Figura 53. Viviane Vallades. Autorretrato com duração e sons variáveis I.2011

Vídeo registro do trabalho. Disponível em: 〈 https://www.youtube.com/watch?v=TqHnXP_vYrE > 


\section{Autorretrato com duração e sons variáveis II / ano 2012}

Nesta obra da série estamos de frente e mirando a câmera. Quase também não realizamos muitos movimentos exceto os de piscar e nos movermos lentamente. A imagem fica levemente flutuante devido à gravação ter sido realizada com a câmera na mão. Aliás, esta particularidade é ressaltada na visualização da imagem, não havendo aqui o objetivo de esconder ou camuflar esse procedimento.

Este trabalho foi exposto em $28^{\circ}$ Salão Nacional de Artes Plásticas de Embu das Artes em 2012.

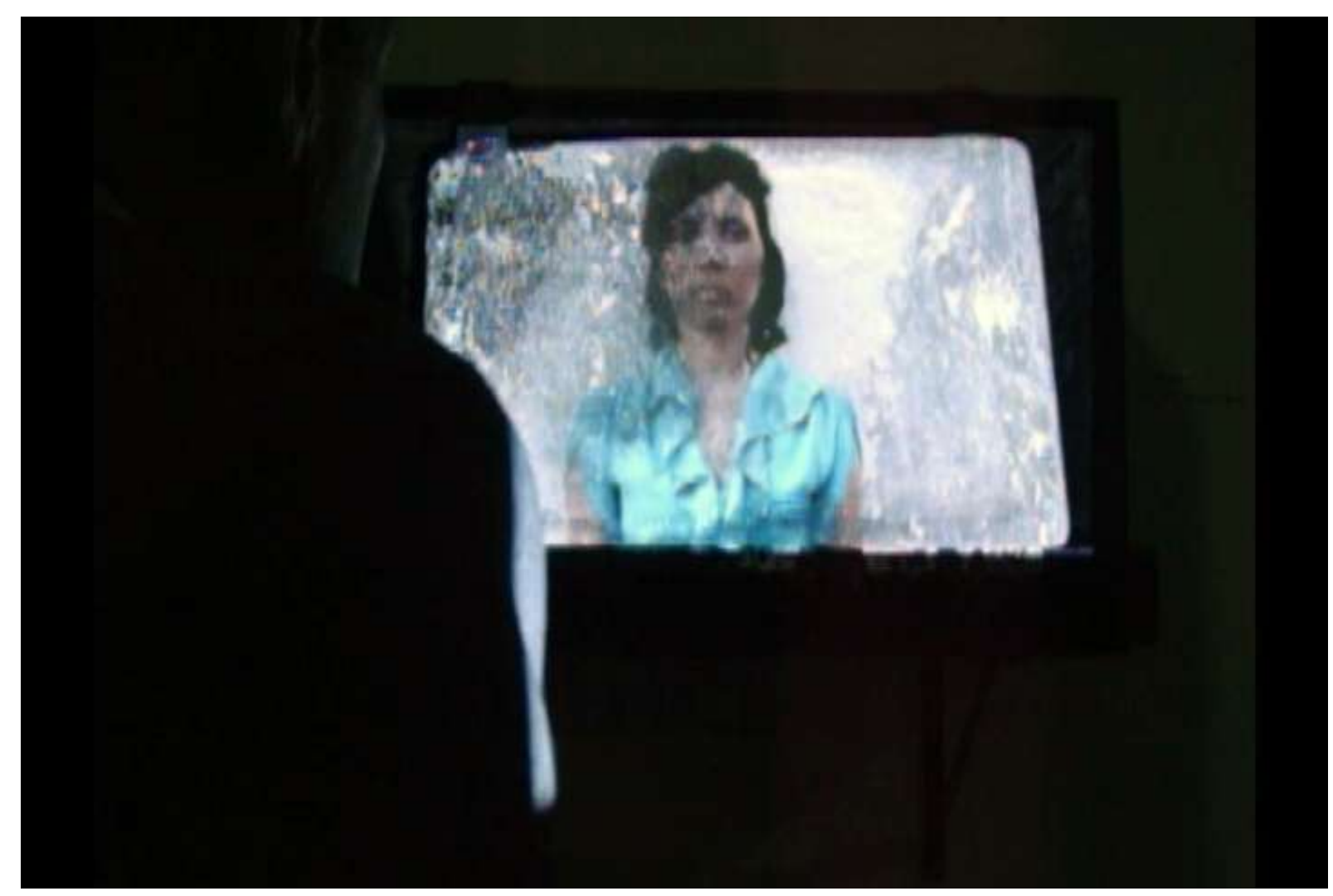

Figura 54: Viviane Vallades. Autorretrato com duração e sons variáveis II. 2012

Vídeo registro do trabalho. Disponível em < https://vimeo.com/52855339 >

\section{Autorretrato com duração e sons variáveis III / ano 2012}

Esta obra da série é constituída da projeção de nosso corpo inteiro e flutuante sobre telas de gelo. Três vídeos projetam cabeça, tronco e pernas em looping simultaneamente sobre três telas de gelo, apoiadas em três caixas separadas e alinhadas na vertical com espaço de aproximadamente $1,0 \mathrm{~cm}$ entre elas. Neste caso, trabalhamos tanto os conceitos levantados quando tratamos da série em geral, acima, como também com multiprojeção e multitelas pelo 
uso de mais de uma projeção e mais de uma tela para exibição da obra.

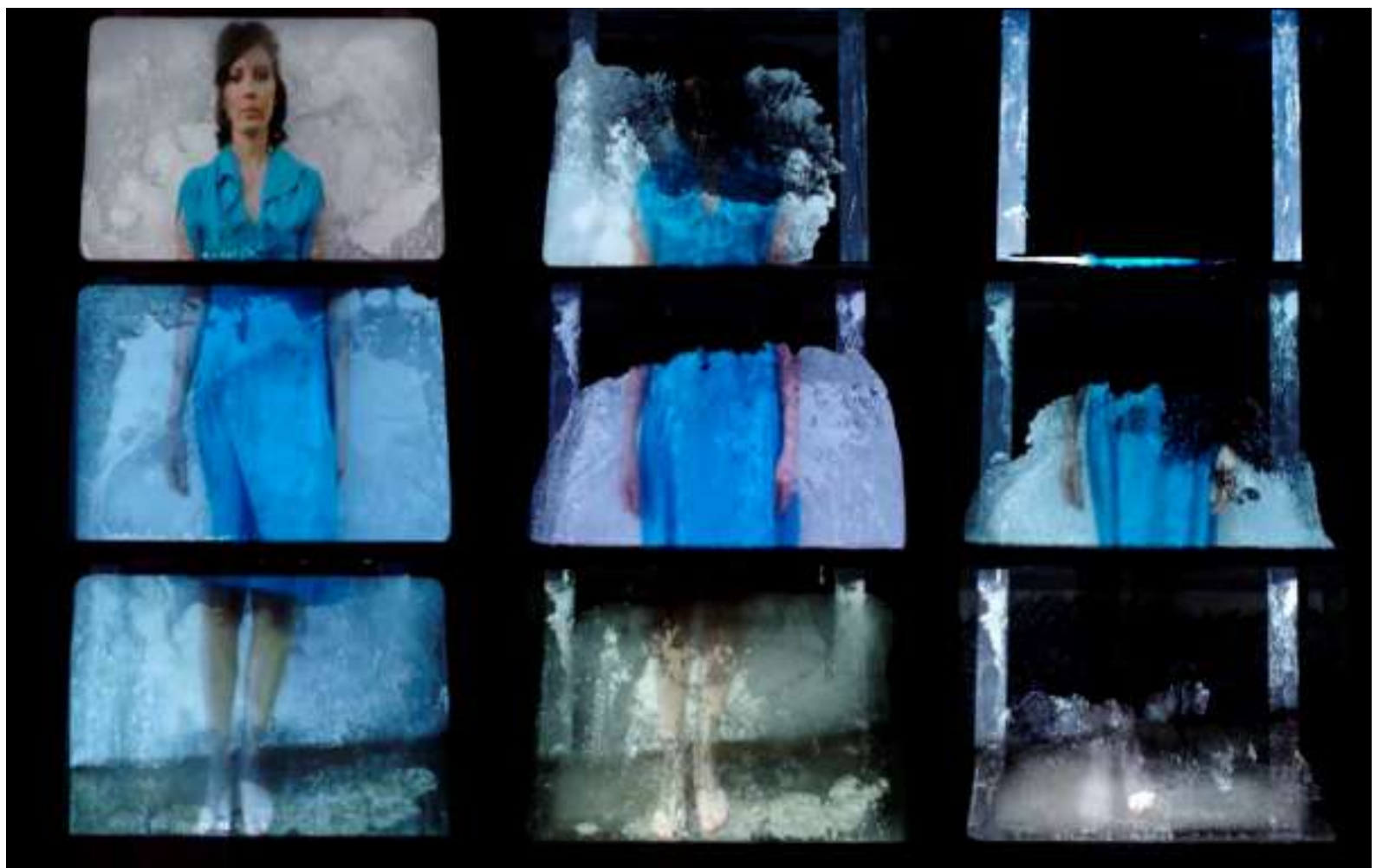

Figura 55:Viviane Vallades. Autorretrato com duração e sons variáveis III. $2012^{56}$

Vídeo registro do trabalho. Disponível em < https://www.youtube.com/watch?v=DM1q_-FaQ1s $>$

\section{Autorretrato com duração e sons variáveis IV / ano 2014}

Esta obra da série consiste em um vídeo projetado em uma tela de gelo. Nele caminhamos lentamente em direção a um espelho, nos observamos por algum tempo e nos afastamos. Essa ação fica em looping.

Esta obra foi selecionada para participar da exposição coletiva do $22^{\mathrm{a}}$ edição do Programa Nascente da USP que será realizada em agosto e setembro de 2014, no Centro Universitário Maria Antonia.

\footnotetext{
${ }^{56}$ Estas fotos foram retiradas da prova de conceito que realizamos em estúdio. Nós fizemos uma edição em vídeo e assim produzimos a junção destas três partes dos vídeos separados, como um protótipo (ou prova de conceito) para futura exibição pública.
} 


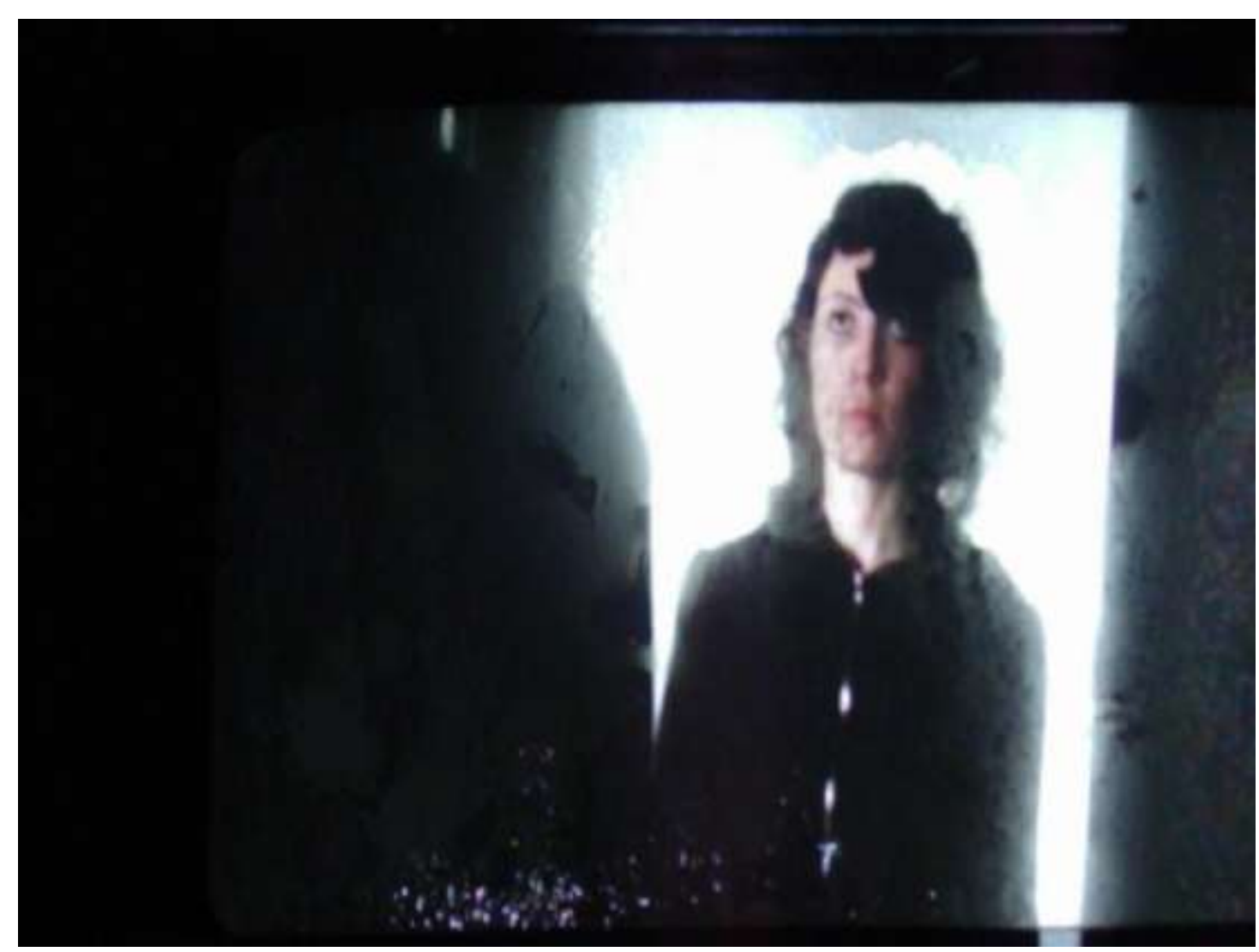

Figura 56: Viviane Vallades. Autorretrato com duração e sons variáveis IV. 2014

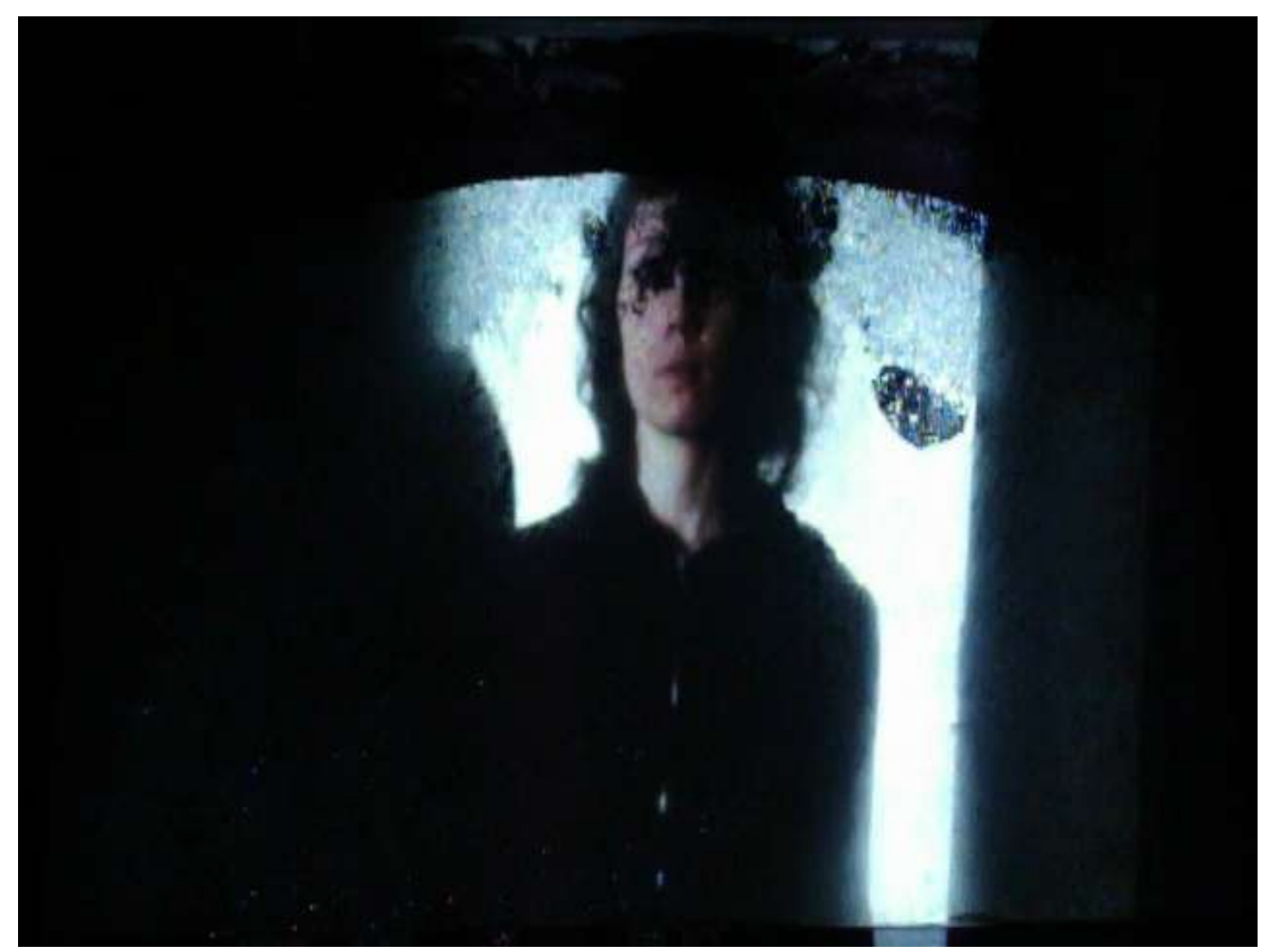

Figura 57: Viviane Vallades. Autorretrato com duração e sons variáveis IV. 2014

Vídeo registro do trabalho. Disponível em $<$ https://www.youtube.com/watch?v=hxnmicdM7wQ $>$ 


\subsubsection{Janelas}

\section{Vídeo/ 11'16"/ 2011.}

O vídeo é uma sequência contínua de nosso ato performático, que consiste em movimentar janelas que nunca se abrem completamente, apresentando o interior através de reflexos e indiretamente (por reflexos) o ambiente externo, ao mesmo tempo que mostramos o processo de criação artístico. Coreografia, som, espaço e composição são produzidos pelas próprias janelas e por meio da adição de múltiplas janelas.

Nesta obra, nosso corpo é trabalhado como um instrumento que pelos seus atos, juntamente com os elementos, objetos (como as janelas, neste caso) que manipulamos, dão visibilidade ou não a partes do ambiente que vão aparecer no vídeo. Controlamos a luz através de nosso ato de abrir e fechar as janelas.

De acordo com nossas pesquisas, esta obra se insere no uso do corpo do artista e sua relação com a câmera e edição (vista por nós no capítulo 1,e também no 2 quando tratamos do corpo e imagens em movimento). Nesta obra, como na maioria das outras, trabalhamos com efeitos de edição que modificam as qualidades espaciais e temporais registradas nas imagens. O corpo, aqui, parece estar em espaços ambíguos devido ao uso de diversas camadas, sobreposições de imagens e multijanelas dentro de uma tela. 

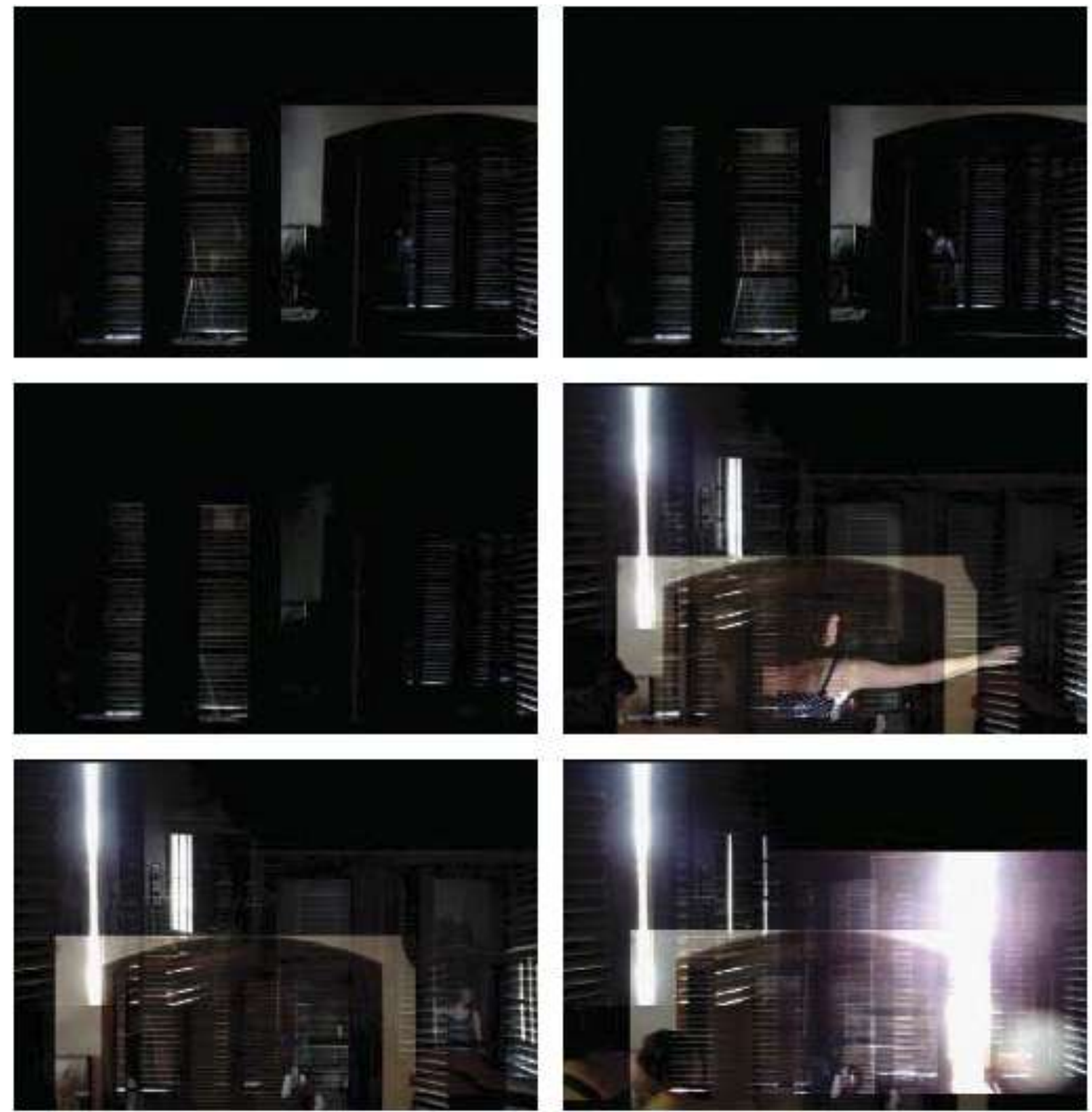

Figura 58. Viviane Vallades. Janelas. $2011^{57}$

Link do vídeo < https://vimeo.com/47126469 >

\subsubsection{Série intitulada: Sem Título}

A série que descreveremos a seguir, intitulada Sem Título, é composta por três vídeos numerados de I a III. Ela foi inicialmente pensada e realizada para ser exibida por três projeções simultâneas em três paredes de uma sala. Mas acabou sendo apresentada (até o

${ }^{57}$ Este vídeo participou dos seguintes festivais e exposições: 2012 FILE -Festival Internacional de Linguagem Eletrônica em SP, MARP- Museu de Arte de Ribeirão Preto Pedro Manuel Gismonde, e em 2011 : $10^{\circ}$ Salão Nacional de Arte de Jataí MAC (GO) no qual obteve Prêmio aquisição. 
momento) em separado e em monitores comuns.

Nos dois primeiros vídeos da série, caminhamos segurando um espelho que tem quase nosso tamanho. No terceiro vídeo, seguimos nosso reflexo em um espelho em movimento. Este movimento no espelho é realizado por Mercedes Espirito da Silva, colaboradora de vários trabalhos de nossa autoria. Ela segura um espelho e caminha com ele (sem ser vista), e nós o vamos seguindo. Estamos em dois ambientes nesses vídeos: 1) em uma casa nos vídeos I e III da série; 2) em uma laje externa. A diferença dos vídeos realizados na casa refere-se à iluminação. No vídeo I, a iluminação da casa é diurna e no III é noturna,. porém iluminada artificialmente por uma lamparina que carregamos nas mãos. A lamparina direciona a iluminação e o que fica visível no vídeo. Ficam em evidência nas imagens do vídeo: o espelho (que apresenta nosso reflexo) e o caminho que realizamos ao segui-lo. Nas três obras da série revelamos a produção do trabalho no momento em que ele está sendo feito. Mostramos que estamos segurando o espelho e que é este gesto, juntamente com o que a câmera enquadra, que produz e compõe as imagens apresentadas. Rompemos também, em vários momentos do vídeo, a função refletora dos espelhos ao mostrarmos o lado oposto deles, interrompendo por algum tempo a aparição de imagens refletidas. Embora os vídeos passem por edição de imagens que intensifica os gestos realizados durante a gravação, eles mantêm o registro de como foram realizados.

Dentro da pesquisa realizada, esta série está inserida na ação do corpo em junção com a imagem em movimento (ver capitulo 2, tópico 2.9). Tanto nesta série como na comentada anteriormente, realizamos uma performance para a câmera. Porém, aqui, no momento da performance, utilizamos nosso corpo como instrumento, em atos e em sua relação com objetos (neste caso, a manipulação de espelhos, que enquadra, modifica o que seria apresentado naquele espaço). O gesto realizado é como uma extensão da mão do pintor. Neste trabalho, ao invés de usarmos tintas para produção de imagens, é nosso corpo que funciona como instrumento, ao segurar um espelho para enquadrar e selecionar as imagens. Utilizamos também multicamadas e multijanelas na edição desses vídeos dentro da tela única Trabalhamos, assim, com procedimentos de edição/montagem dos cinemas experimentais e também de videoarte. Por meio desses procedimentos, várias imagens são apresentadas em uma única tela, diferentemente da apresentação de uma imagem que ocupa a tela toda. A edição/montagem dentro de uma única tela é uma técnica que trabalha e apresenta várias imagens que pertencem a outros espaços-tempo, mas coexistindo. Embora aqui nesta série (pelo menos como ela foi apresentada até o momento ) a tela seja tradicional, a divisão 
realizada dentro dela, devido a diversas camadas, sobreposições e fusões, possibilita várias leituras e composições, o que se explica também pelo excesso de informação que a tela comporta.

\section{Sem Título I}

\section{Vídeo/ ano 2011/ 05’00”}

Carregamos um espelho e nele, imagens. Através de diferentes enquadramentos gerados pela movimentação do espelho e câmera revelamos o espaço de uma casa e é ainda por meio desses enquadramentos de câmera e espelhos que ora o duplo no espelho parece guiar o referente ora o referente parece guiar o duplo.

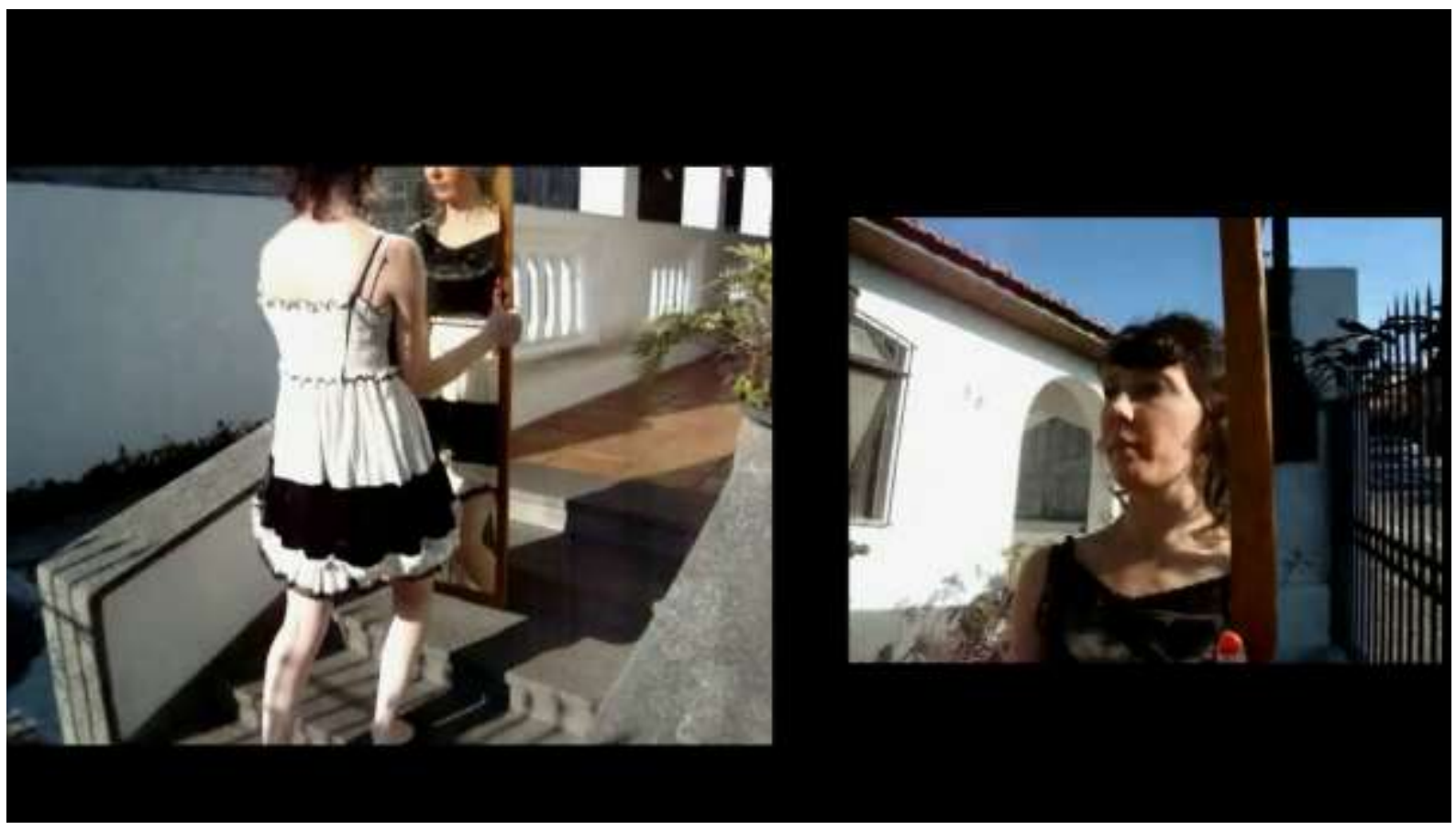

Figura 59: Viviane Vallades. Sem Título I, 2011

Link do vídeo < https://www.youtube.com/watch?v=MlNkQO3PyIA >

\section{Sem Título II}

\section{Vídeo/ 04’25’/2011}

Durante um ato performático e a intervenção provocada por um espelho, realizamos o vídeo, construindo novas paisagens ao manipular a visibilidade da paisagem "real". O trabalho enfoca a construção das imagens apresentadas aqui, assim como as relações entre máquinas, espelhos e a própria artista. A obra, enfim, é feita de manipulações para construir 
paisagens com tempo e espaços alterados.

Resumindo, usamos nosso corpo ligado a objetos, neste caso o espelho, para criar, direcionar e potencializar a aparição de imagens visando modificar a paisagem "real" em que estamos inseridos. Através desse procedimento, escondemos partes que seriam visíveis sem o espelho e trazemos também pelo uso do espelho partes que estariam fora de campo. Neste trabalho, como na maioria dos outros, a construção da obra se dá durante o processo de produção, ou seja, é na própria obra que se revela o mecanismo pelo qual ela toma forma. 

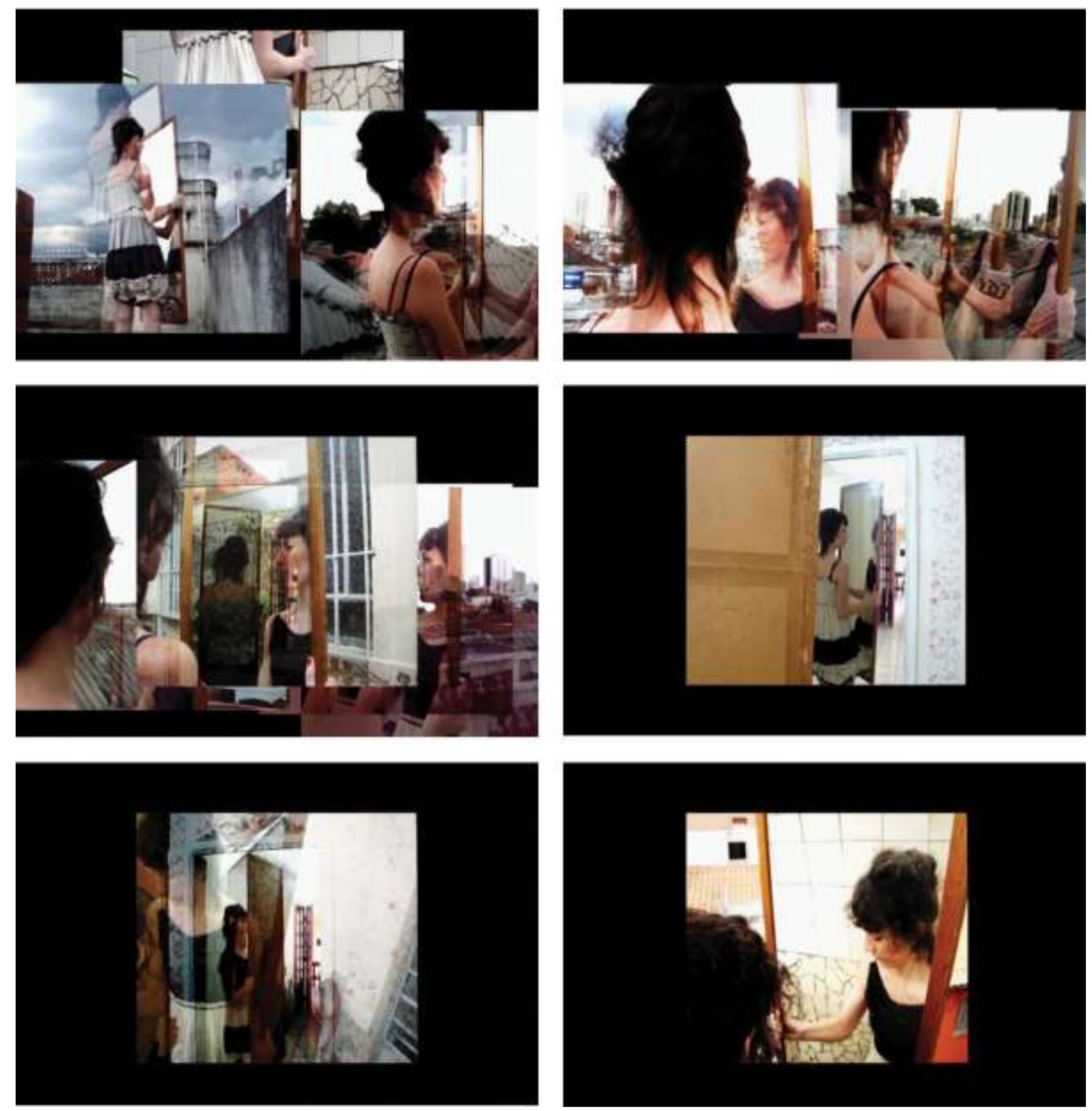

Figura 60: Viviane Vallades. Sem Título II. 2012. ${ }^{58}$

Vídeo disponível em < https://vimeo.com/58820758 $>$

\section{Sem Título III}

\section{Vídeo/03'59"/2011}

Através de um ato performático, seguimos, guiados por um lampião, nossos reflexos num espelho que está em movimento. Tentamos assim criar uma metáfora para o

\footnotetext{
${ }^{58}$ Este vídeo participou dos seguintes festivais e exposições: 2013: 12 Salão de Artes de Guarulhos, 2012: FILE Festival Internacional de Linguagem Eletrônica em SP; XI Bienal do Recôncavo (BA)
} 
autoconhecimento. O escuro representa o mundo no qual somos inseridos e é neste escuro que tentamos entender nosso lugar e atingir o autoconhecimento. A obra tem influência da pintura, principalmente da que utiliza contraste entre luz e sombra para criar maior dramaticidade, como a obra de Caravaggio. A luz guia, assim como as pinturas deste tipo, o direcionamento de nosso olhar.

Deixamos em foco (devido à iluminação) o nosso corpo refletido no espelho, e poucas partes do trajeto que realizamos na tentativa de segui-lo, permanecendo o restante da cena mais escurecido

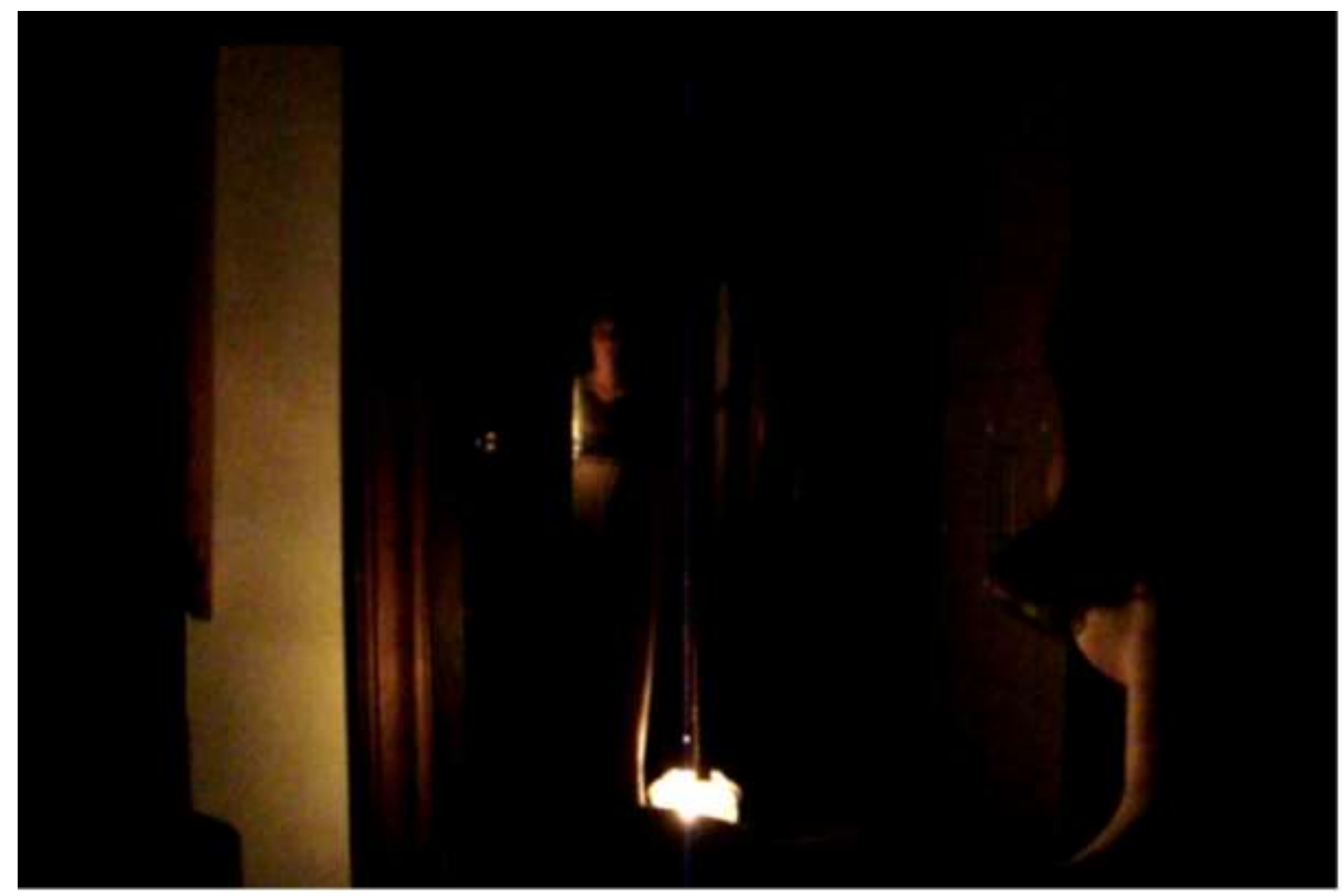

Figura 61. Viviane Vallades. Sem Título III. 2011

Vídeo disponível em < https://www.youtube.com/watch?v=51Dlts7qffE $>$

\subsubsection{Pintura em Atos}

\section{Videoinstalação/ 06’36”'em looping/ 2012}

Em Pintura em Atos, realizamos pinturas (de uma forma inusitada) em nosso corpo, vestindo trajes não tão usuais, semelhantes a pinturas antigas. Registramos o processo em vídeo e nele expomos a construção da obra. O vídeo é uma visão frontal da pintura que 
realizamos em nosso corpo (em quatro janelas simultaneamente e feitos em um mesmo vídeo). Entramos em cena, no quadro do vídeo, nos pintamos e saímos desse quadro. O vídeo tem sons ambientes e ruído de água caindo quando jogamos tinta em nosso corpo.

O corpo é aqui utilizado como suporte para a pintura. A projeção do vídeo sobre folha de Eucatex perfurada e suspensa no espaço expositivo é que nos possibilita construir uma relação com esse espaço. O vídeo dessa pintura é assim apresentado em camadas. Uma parte do vídeo é visualizada na folha de Eucatex e a outra parte, na parede situada atrás da folha. Devido ao modo de exibição da obra: folha suspensa, projeção em camadas (na folha de Eucatex e na parede), a obra requer a percepção, o deslocamento do espectador pelo espaço onde se apresenta.

Esta obra esta inserida na pesquisa realizada principalmente no que se refere a formas diferenciadas das padronizadas formas de apresentação de imagens em movimento, ligando-se assim ao cinema de exposição. Principalmente pelo uso de dispositivos associados ao cinema, mas com desvios nos modos de exibição. Neste caso, o foco é o uso de duas telas para exibição (folha de Eucatex e parede) e de materiais diferenciados da tela padrão de apresentação do audiovisual (tela de cinema de sala de exibição ou monitor) e pela sua disposição no espaço expositivo. Essa obra também se insere nas pesquisas do corpo em junção com imagem em movimento. Ela pode ser pensada como um exemplo do desdobramento de performances realizadas para a câmera que podem, também, ser apresentadas, transformadas em videoinstalações. Como visto no capítulo II, quando tratamos do corpo, a maioria das performances realizadas para a câmera até 1970 aproximadamente eram exibidas em monitores. Segundo Santaella, é por volta de 1990 que o "potencial do vídeo para as experimentações com o corpo do artista veio intensificar-se com a hibridização do vídeo nas videoinstalações [...] (SANTAELLA, 2008, p.268). Assim, cremos que esta obra contém elementos que nos levam a pensar nessa hibridização entre performance, vídeo e videoinstalação. Em um primeiro momento, durante a realização do trabalho, existe de nossa parte um ato performático em que nosso corpo é o instrumento e o suporte para a pintura enquanto registramos este ato em vídeo. Mas, durante a exibição do trabalho no espaço expositivo (videoinstalação), é o corpo do espectador que entra em ação, pelos seus movimentos pelo espaço e pelo uso de sua percepção para completar partes faltantes das imagens durante sua visualização nas superfícies: Eucatex perfurada e parede.

Esta obra também serviu para pensarmos sobre a classificação de telas feita no capítulo III. Aqui se usou a classificada como tela perfurada. As telas perfuradas possuem 
formas vazadas, sejam elas geométricas ou irregulares, e permitem que a luz atravesse partes faltantes da superfície de projeção e se visualizem imagens projetadas em mais de uma superfície.

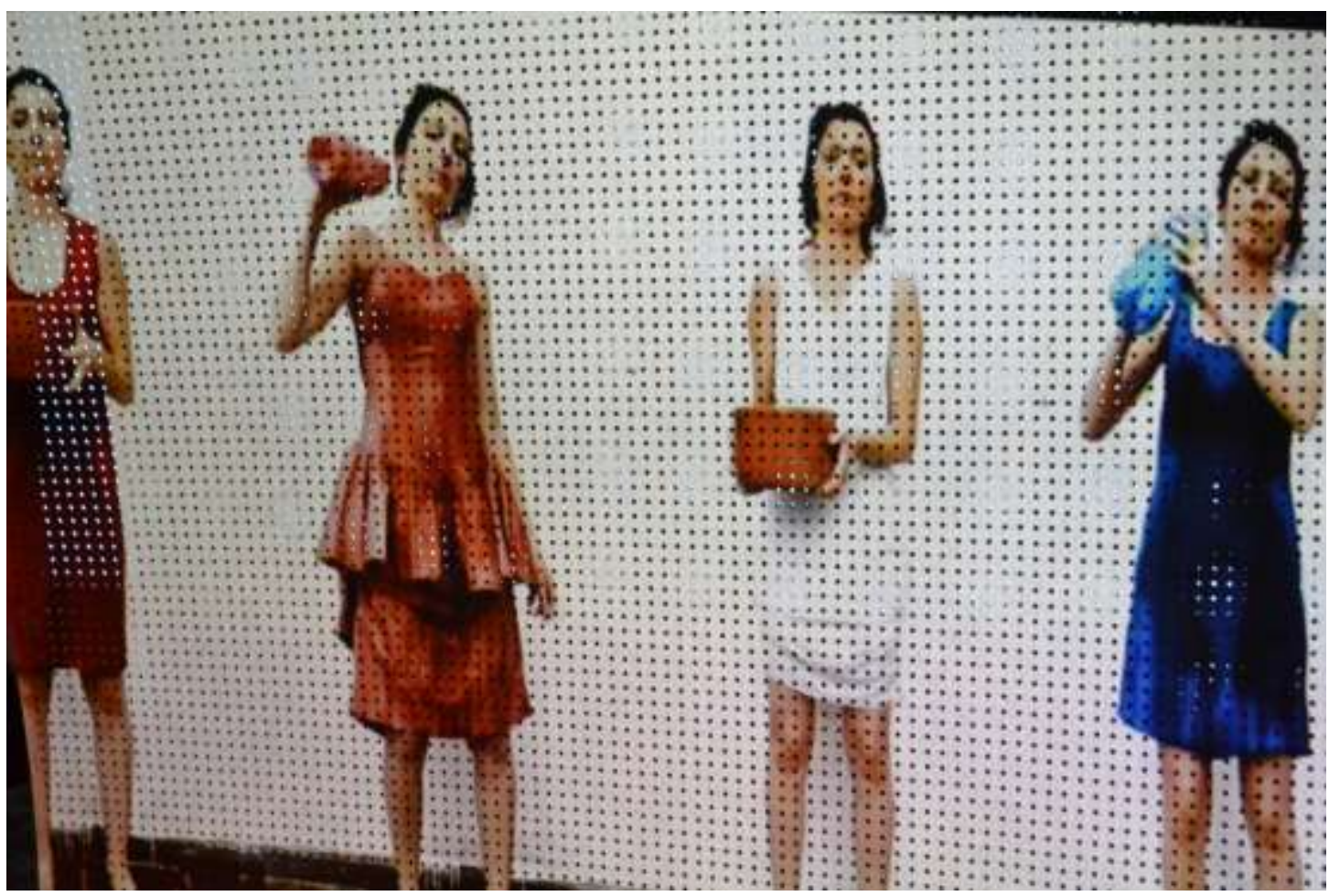

Figura 62. Viviane Vallades. Pintura em atos. 2012

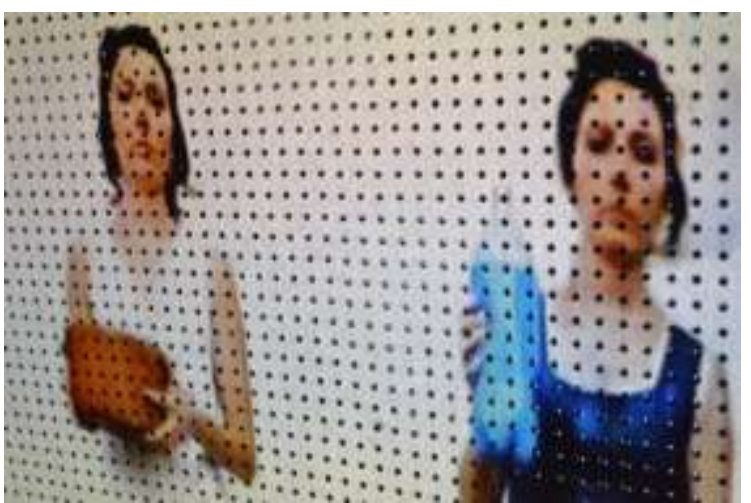

Figura 63. Viviane Vallades. Pintura em atos. 2012 


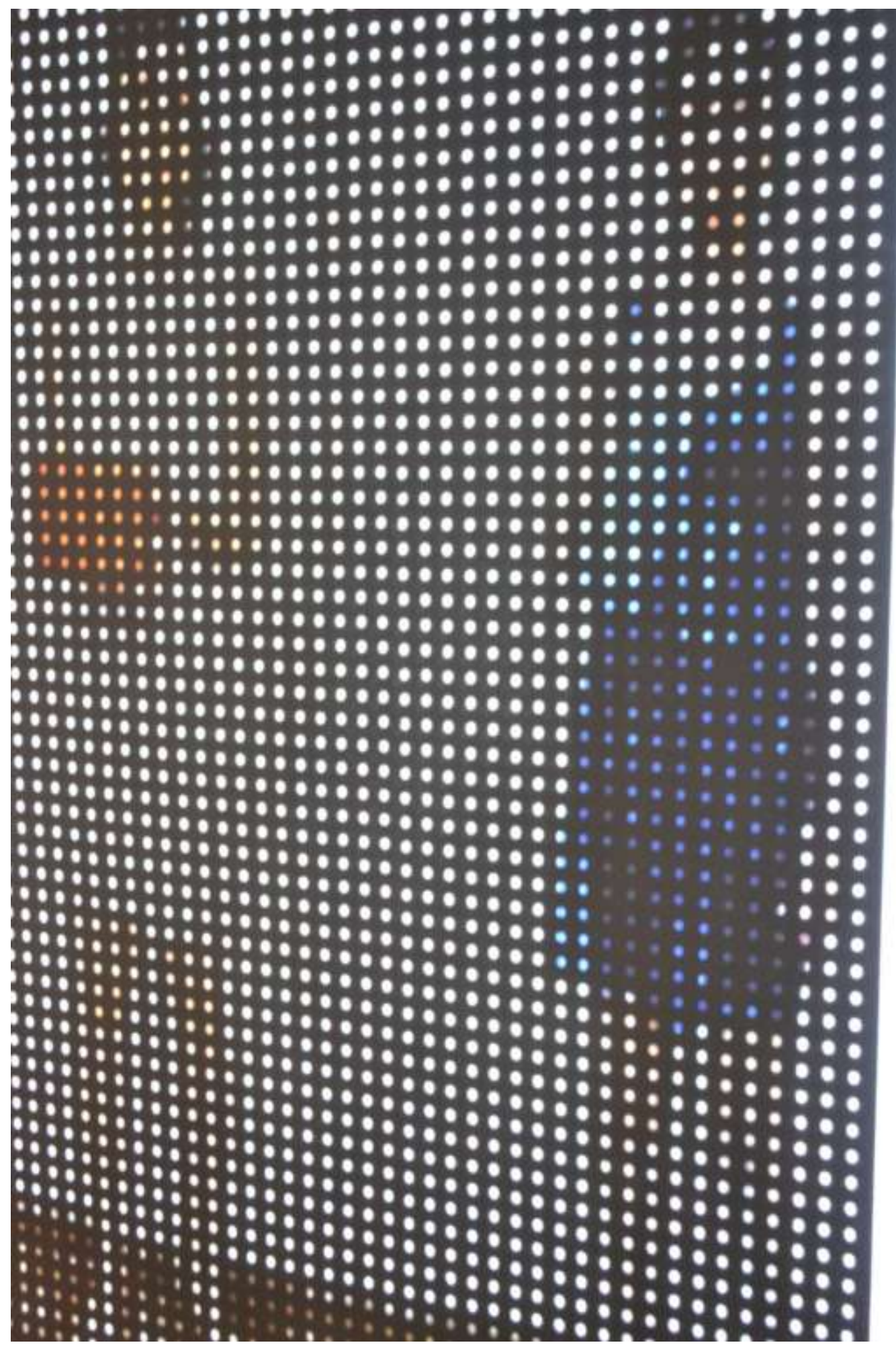

Figura 64. Viviane Vallades. Pintura em atos. $2012^{59}$

Registro do trabalho, disponível em: https://www.youtube.com/watch?v=u0138-9VyeU

$<$ https://www.youtube.com/watch?v=lXCWV2bFLtA >

${ }^{59}$ Este trabalho participou da seguintes exposições: 2013: II Salão Xumucuís de Arte Digital, Belém-Pará/ Brasil e 21 Programa Nascente - Centro Universitário Maria Antonia - no qual obteve Menção Honrosa 


\subsubsection{Sem Título}

\section{Vídeo/ 03'46"'/ 2012}

Janelas são abertas e fechadas e não mostram como de costume o espaço externo; não são aberturas. $\mathrm{O}$ espaço externo é vetado pelo preto adicionado ao fundo da janela. $\mathrm{O}$ abrir e fechar da janela é realizado por nosso ato performático e insistente de manipulá-las.

Este trabalho, como os descritos anteriormente, está inserido na pesquisa realizada principalmente na relação do corpo com a imagem em movimento e do corpo como instrumento e na apresentação de múltiplas imagens por meio de múltiplas janelas dentro de uma única tela.

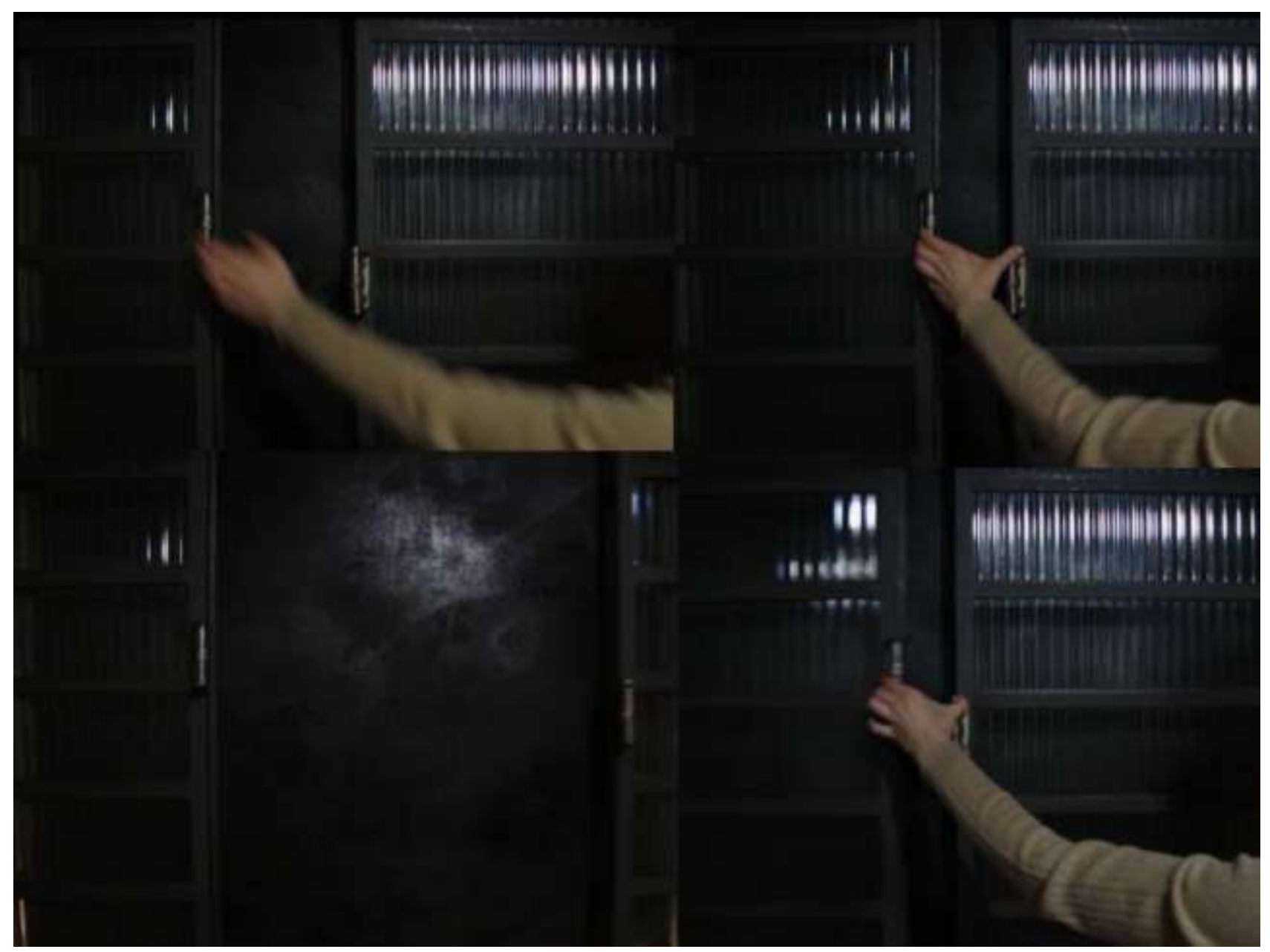

Figura 65. Viviane Vallades. Sem Título. 2012

Vídeo disponível em https://www.youtube.com/watch?v=rFmm-ToOn3g 


\subsubsection{Sem Título}

\section{videoinstalação/04'00"/ 2012}

Durante um ato performático, nós nos movemos em um espaço (nosso banheiro) e construímos relações espaciais entre nossos movimentos pelo espaço e ecos visuais, espaciais de nosso corpo através dos reflexos e do vídeo.

Este vídeo é projetado sobre um espelho que está sob um cavalete de pintura. O vídeo pode ser visualizado no espelho e na parede oposta do espaço expositivo, através da reflexão da projeção causada pelo espelho.

Esta obra abrange principalmente as questões da pesquisa que envolvem a relação corpo e imagens em movimento. Trabalha, como algumas das obras já comentadas, com edição de vídeo. O corpo apresentado aparece duplicado, triplicado por processos de edição. Modificamos o corpo, ou seja, a imagem captada pela câmera, criando algo fantasmático a se observar. Esta obra também se insere nos modos diferenciados de apresentação das imagens em movimento pelo uso de multitelas. As imagens podem ser visualizadas tanto no espelho como na parede oposta do espaço expositivo.

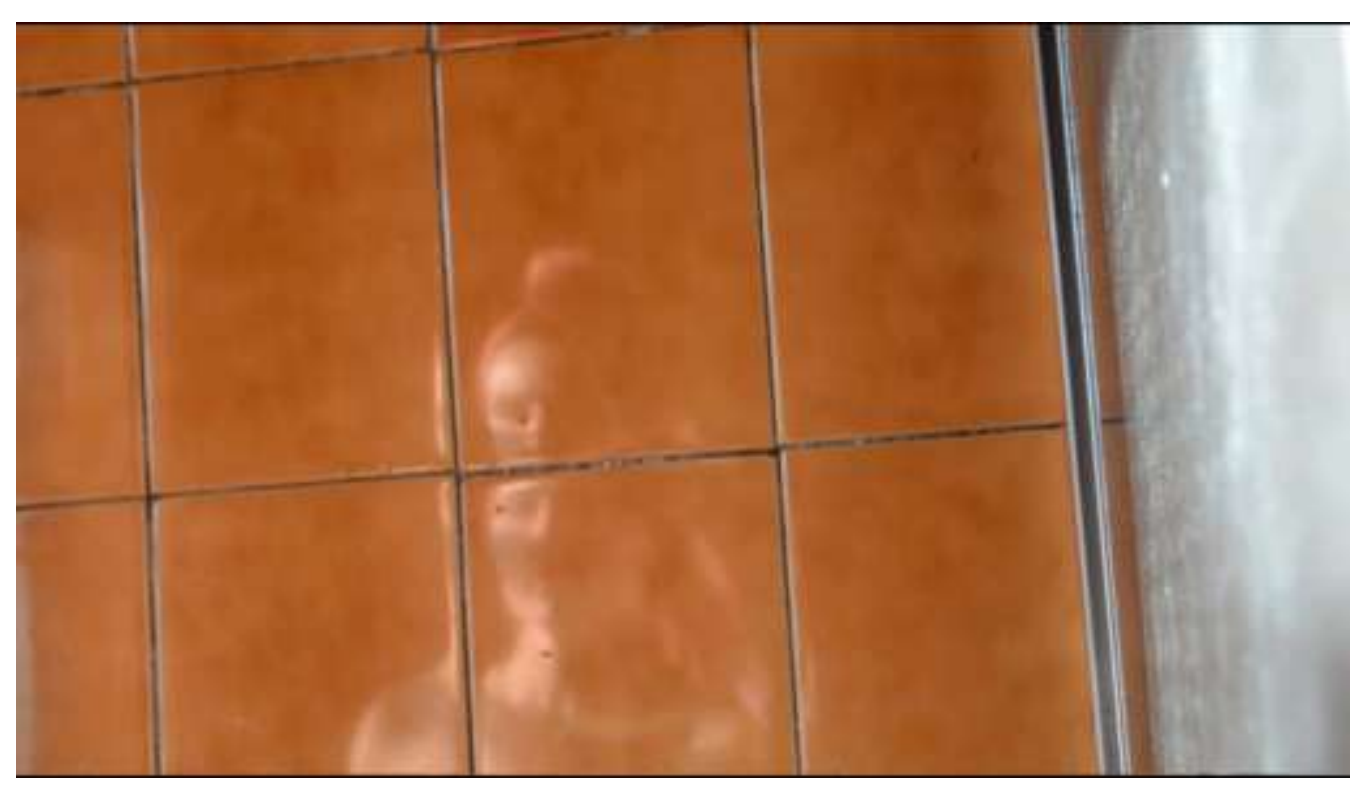

Figura 66. Viviane Vallades. Sem Título.2012

Apenas o vídeo da videoinstalação está disponível: https://www.youtube.com/watch?v=aNUTz2g-VkI 
Montagem da videoinstalaçŏo "Sem Titulo"

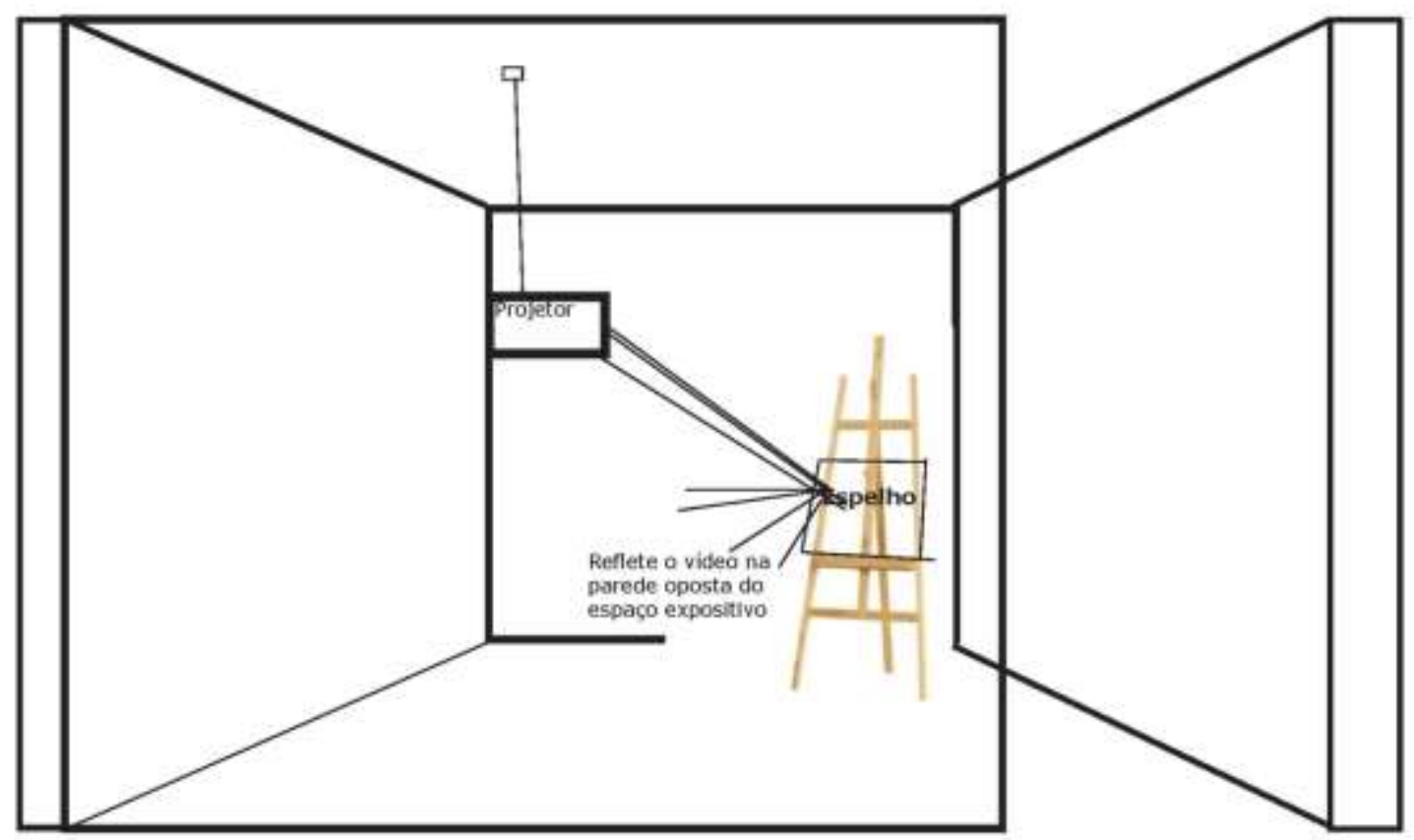




\section{Conclusão}

O homem sempre exteriorizou seus pensamentos, anseios e conceitos sobre superfícies. Essas representações foram observadas em imagens estáticas e também em movimento, obtidas por mecanismos que vão desde trabalhar com sombras, diante de telas, até a produção de pinturas em placas de vidro em junção com um projetor, brinquedos ópticos e uma infinidade de outras possibilidades. Todas essas representações usaram telas para sua visualização, seja no campo das artes visuais, nos dispositivos pré-cinematográficos, ou no cinema e mais intensamente na contemporaneidade, expandindo-se em múltiplas telas, de diversos formatos, materiais e tamanhos. Se existe uma certeza na contemporaneidade, essa certeza é a do aumento das telas. Elas estão em salas de cinema, aviões, carros, mercados, nas mãos das pessoas nos ônibus, metrôs etc. Para este estudo nos limitamos a tratar mais especificamente de obras instalativas com imagens em movimento que façam uso de exibição de telas diferenciadas das padronizadas, seja em quantidade, disposição espacial e também que façam uso de superfícies espelhadas, efêmeras, instáveis, incompletas etc.

Procuramos no decorrer de todo o texto destacar sua importância, dentro da perspectiva histórica, que revelou que esse elemento foi modificado, pensado, destacado e fundamental em vários contextos e obras. Contemporaneamente, observa-se com mais intensidade nas práticas artísticas o uso do dispositivo do cinema: projeção, tela, espaço escuro, filmes, na construção, exibição de obras que são apresentadas em espaços de arte, dentre outros. Esse fenômeno de invasão de imagens em movimento nos espaços de arte recebeu vários nomes, dentre eles cinema de exposição. Tais obras apresentam modificações no dispositivo cinema, inclusive do elemento tela, e foram as modificações nesse elemento o foco de nosso estudo.

O propósito de traçar um histórico com ênfase no elemento tela se deveu por observarmos que os procedimentos contemporâneos, no modo de trabalhar ou pensar a apresentação das imagens em movimento nos espaços de arte, dentre outros, e usar telas diferentes da tela retangular, frontal e branca (que pode ser a mesma usada para apresentação de diversos filmes) não são totalmente inéditos. Daí nossa intenção com este histórico no sentido de contribuir com um estudo que aponte exemplos de obras que façam uso desse elemento de forma diferenciada. Embora a tecnologia atual difira das anteriores, facilitando o modo de apresentação e agregando outras possibilidades (como a interação), existe uma retomada de procedimentos anteriores no que se refere aos modos diferenciados de exibição 
de imagens em movimento, principalmente no que se refere a tela. A nosso ver, esses modos diferenciados de exibição retomam procedimentos de pré-cinema e também dos cinemas que alteram o dispositivo padronizado do cinema: tela grande, retangular e frontal, pessoas sentadas, um único projetor. Entendemos, também, que as obras que trabalham a tela de modo diferenciado se hibridizam a procedimentos de artes visuais. Justificamos algumas de nossas hipóteses lançadas na introdução de nossa dissertação, como por exemplo, a existência de hibridização entre cinema e artes visuais, referindo-nos a procedimentos no tratamento e uso de telas diferenciadas em instalações para exibição de imagens em movimento. Tentamos averiguar essa analogia de procedimentos, apontada por nós, traçando no capítulo $1 \mathrm{um}$ histórico das artes visuais, com foco no tratamento dado às telas de pintura, isto é, como eram trabalhadas para receber as pinturas e como isso foi posteriormente um elemento destacado em si. Ainda nesse capítulo ressaltamos a abertura que as artes visuais trouxeram no uso de elementos e materiais, suportes diversos, como por exemplo, as obras de arte a partir de objetos prontos, industriais, do cotidiano, o uso do corpo, de imagens em movimento etc. Apontamos aí uma hibridização de procedimentos pelo uso de telas diferentes de exibição padronizada associada a imagens em movimento como tela retangular, branca, frontal ou monitor, que servem para exibir qualquer filme ou vídeo. Observamos que algumas obras que trabalham a apresentação de imagens em movimento diferente do modo padronizado usam esculturas, objetos do cotidiano como ventiladores, espelhos, materiais efêmeros como gelo etc. A nosso ver, esse uso se liga, a procedimentos de artes visuais na escolha de formatos diferenciados, modo de preparação das telas (que nesse caso irão receber projeção e não tinta) e na escolha de materiais, tanto por sua materialidade em si, como por sua carga de significado. No audiovisual, como o cinema de sala ou mesmo o vídeo, a tela é quase sempre vistas apenas como superfície neutra para apresentar as imagens e o que mais importa é a edição, as imagens, o enquadramento, etc., isto é, o que aparece projetado na tela e raramente a própria tela. Embora em salas de cinema a tela seja de tamanho monumental, logo que o filme ou vídeo se inicia, ela fica em segundo plano. Os monitores também são feitos para visualização de imagens e embora tenham diversos tamanhos e formatos e que estes tamanhos e formatos realmente mudem a forma de se relacionar com o que está sendo visualizado, acabam sendo vistos frequentemente apenas como superfícies neutras de uso comum para apresentação de diversos trabalhos.

Nas instalações que se utilizem de imagens em movimento (principalmente nos espaços de arte, mas não se limitando apenas a eles), as telas são de variados materiais e 
formatos que são pensados para aquela obra específica, já que devem contribuir para a leitura, poética da obra, e não são superfícies neutras, podem também carregar, por seu material, formato, disposição, uma carga semântica, simbólica e chamar a atenção para si, como quando as imagens são apresentadas em árvores, fumaça, gelo etc. Consideramos que o uso de diversos materiais e a sua fisicalidade dotam as telas e a imagem de plasticidade, o que é, para nós, uma hibridização procedimental entre cinema e artes visuais.

Também podemos dizer que a outra parte de nossa hipótese, se comprova e se afirma; a de que essas obras contemporâneas que fazem uso de telas diferenciadas retomam também procedimentos de pré-cinema e cinemas experimentais. Esta parte da hipótese foi fundamentada no histórico traçado no capítulo 2, que traz um panorama de pré-cinema com foco em descrições e usos de telas e de como eram pensadas, observando-se que as telas transparentes, de fumaça, muito comuns em obras contemporâneas, já eram ali muito usadas. Também foi observado por descrições que, na câmara escura, a apresentação das imagens não ocorria apenas frontalmente, mas também no chão ou teto, como nas experiências de Kircher realizadas com prismas na câmara escura (embora não seja de fato o modo ali mais frequente de exibir imagens)

O uso de obras que utilizem de diversas telas também é visto por todo o capítulo 2 , onde fizemos no tópico 2.7 referências à obra Napoléon de Abel Gance, que em 1927 faz a experiência monumental do uso de três telas em determinados momentos do filme. Destacamos que esse procedimento de três telas é muito comum na apresentação contemporânea das imagens em movimento. E ao analisar a obra de Abel Gance, trouxemos o estudo de Jean-Jacques Meusy que vê no uso das três telas uma retomada dos trípticos de pintura, ligando assim este formato às artes visuais. Continuamos comentando obras de cinema expandido que utilizam diversas telas para passarmos, enfim ao capítulo 3 e observamos que o uso de telas diferenciadas foi ampliado. O uso de imagens em movimento no contexto da arte também foi alvo de nossos comentários.

No capítulo 3, ainda fizemos análises de obras que utilizam imagens em movimento projetadas em telas diferenciadas. Destacamos nessas obras tanto o uso de materiais diferenciados, quanto, o modo de visualização diferentes do modo padrão. Nas análises trouxemos falas dos próprios artistas (tais como Rosângela Rennó e de Tony Oursler) para observar a ligação que essas obras possuem com o pré-cinema, principalmente pelo uso que elas fazem, dentre outras coisas, de telas de fumaça, por exemplo.

Nas descrições das obras de nossa autoria, ressaltamos a importância da tela por 
contribuir na modificação das imagens exibidas, pela sua função simbólica, por fazer variar a duração de apresentação das imagens e por dotar de características diferenciadas as apresentações das imagens em movimento. Estas possibilidades comentadas aqui e mais bem explicadas no capítulo 3 nas descrições de obra e na parte de classificação de telas,foram possibilitadas pelo uso de materiais, como gelo, telas perfuradas e suspensas no espaço, múltiplas projeções em múltiplas telas.

A importância das telas foi destacada principalmente em três das obras descritas: a série Autorretratro com duração e sons variáveis; Pintura em atos e em Sem título. A série intitulada Autorretrato com duração e sons variáveis, descrita e comentada no capítulo 3 na no tópico 3.4.2 foi o motivo inicial do interesse nesta pesquisa. Assim que realizamos esse trabalho, que usa como superfície de projeção uma tela de gelo, muitas questões sobre as telas, sua materialidade, seus formatos, duração, disposição espacial apareceram e foram sendo tratadas neste estudo. Este trabalho também serviu para pensarmos em uma de nossas hipóteses, a de que o uso de materiais não tradicionais no audiovisual ligam esses trabalhos com superfícies diferenciadas às artes visuais.

Foi também a partir desse trabalho e de outros que foram sendo realizados no decorrer da pesquisa, somado a diversas leituras sobre as telas e modos de apresentação de imagens em movimento, com destaque para as leituras de Philippe Dubois, que desenvolvemos um pensamento e uma breve classificação das telas no capítulo 3. Tomamos como base a observação de certas características ressaltadas das telas que, a nosso ver, contribuem para seu estudo e ressaltam sua importância no ato de exibição das imagens.

Muitos outros exemplos foram deixados de fora deste estudo; selecionamos apenas algumas obras que entendemos suficientes para mostrar e destacar o elemento tela pensado, escolhido para aquela obra específica. Este foi o propósito de nosso inicial sobre este elemento que a cada dia se torna mais intenso em todos os espaços inclusive nas obras visuais e audiovisuais contemporâneas. 


\section{Referências Bibliográficas}

ALMAZÁN, Yayo Aznar. Cuerpos de trapo, sujetos vacios. Revista, Re-Visiones \# Dos, 2012. Disponível em: http://re-visiones.imaginarrar.net/spip.php?article68. Acesso em $10 \mathrm{de}$ maio de 2014.

ALZUGARAY, Paula. "Rosângela Rennó: o artista como narrador". São Paulo: Paço das Artes, 2004. Folder de exposição [exhibition folder].

ARANTES, Priscila. @ rte e mídia: perspectivas da estética digital. São Paulo: Editora Senac, 2005

ARCHER, Michael. Arte contemporânea: uma história concisa. Tradução Alexandre Krug, Valter Lellis Siqueira.São Paulo: Martins Fontes, 2001.

ARGAN, Giulio Carlo. Arte moderna: do iluminismo aos movimentos contemporâneos. São Paulo: Companhia das Letras, 2008.

AUMONT, Jacques. A imagem. Tradução Estela dos Santos Abreu. Campinas, SP: Papirus, 1993.

AZZI, Francesca. O portapak é cor de Rosa no Mundinho Black \& White. . Catalogo Fluxus Black White, 2012. Oi Futuro.

BARBOSA Júnior, Alberto Lucena. Arte da animação. Técnica e estética através da história. $2^{a}$ ed. São Paulo: Editor Senac São Paulo, 2005.

BAUDRY, Jean-Louis. "Cinema: efeitos ideológicos produzidos pelo aparelho de base." IN: XAVIER, Ismail (org.). A experiência do cinema : antologia. Rio de Janeiro: Edições Graal: Embrafilme, 1983.

BELLOUR, Raymund. "Cinema, Alone"/Multiple "Cinemas" Alphaville: Journal of Film and Screen Media Issue 5, Summer 2013 Translation by Jill Murphy disponível em http://www.alphavillejournal.com/Issue5/HTML/ArticleBellour.html $\quad$ acessado em $16 / 05 / 2014$

BENTES, Ivana. H.O and Cinema-Word in Hélio Oiticica Quasi-Cinemas. Edited by Carlos Basualdo. Kolnischer Kunstverein. New Museum of Contemporary Art. Wexner Center for the Arts. Hatje Cantz Publishers. Germany/New York. 2002.

Disponível

em: http://webcache.googleusercontent.com/search?q=cache:nd3AiLEIVU4J:www.pos.eco.ufrj.br /docentes/publicacoes/ibentes_novo03.doc $+\& \mathrm{~cd}=15 \& \mathrm{hl}=\mathrm{en} \& \mathrm{ct}=\mathrm{clnk} \& \mathrm{gl}=\mathrm{br}$. (Acesso em 10 de abril de 2014)

BISCAINHO, João José Maças. Experiência de cinema: exposição e conservação. Em busca da performance autêntica. Dissertação de mestrado em Museologia. Faculdade de Ciências Sociais e Humanas. Universidade de Liboa. 2012. Disponível em: http://run.unl.pt/handle/10362/7375 
BORDWELL, David; THOMPSON Kristin. El arte cinematográfico. 6 ed.Tradução Édgar Rubén Cosío Martínez. México: McGraw Hill, 2003.

BOURRIAUD, Nicolas. Pós-produção: como a arte reprograma o mundo da arte contemporânea. Tradução Denise Bottmann. São Paulo: Martins Fontes,2009 (Coleção todas as artes).

BRAGA, Paula Priscila. A trama da terra que treme: Multiplicidade em Hélio Oiticica. Tese de Doutorado. Faculdade de Filosofia, Letras e Ciências Humanas da Universidade de São Paulo, 2007.

CANONGIA, Ligia. Quase Cinema: cinema de artista no Brasil, 1970/80. Rio de Janeiro: Edição Funarte, 1981

CARNEIRO, Beatriz Scigliano. "Cosmococa - Programa in Progress: Heterotopia de guerra". Em: BRAGA, Paula (org.). Fios soltos: a arte de Hélio Oiticica. São Paulo: Perspectiva, 2008.

COOKE, Lynne. Interview Lynne Cooke and Tony Ousler. Disponível para download em <www.tonyoursler.com/files/lynne cooke interview.pdf > Acesso em 28/04/2014)

COSTA, Flávia Cesarino. O primeiro cinema: espetáculo, narração, domesticação. Rio de Janeiro: Azougue Editorial, 2005.

CRUZ, Roberto Moreira dos S. Arte como filme, vídeo como arte. Catalogo Fluxus Black White, 2012. Oi Futuro.

DABROWSKI, Magdalena. Contrastes da forma: Arte geométrica abstrata 1910-1980: das coleções Solomon R. Guggenheim e Museu of Modern Art, New York. São Paulo: Sociedade Cultural Arte Brasil, 1986.

DANCYGER, Ken. Técnicas de edição para cinema e vídeo: história, teoria e prática. Trad. Angélica Coutinho. Rio de Janeiro: Elsevier Campus, 2003.

DANTO, Arthur. Após o Fim da Arte: A arte contemporânea e os limites da história/ tradução Saula Krieger. São Paulo: Odysseus Editora, 2006.

DOMINGUES, Diana. As instalações multimídia como espaços de dados em sinestesia. Relações corpo/arquitetura/ memória e tecnologias. Disponível em http://www.iar.unicamp.br/disciplinas/ap858/AXILA/pagdianadomingues.html acesso em 30/06/2013.

DREHER, Thomaz. Vallie Export / Peter Weibel. Multimedial feminist art. Disponível (para download em pdf) < http://dreher.netzliteratur.net/2_Export.pdf $>$

DUBOIS, Philippe. Movimentos improváveis: o efeito cinema na arte contemporânea. Catálogo da exposição. Rio de Janeiro: Centro Cultural banco do Brasil, 2003.

Cosac \& Naify, 2004.

Cinema, vídeo e Godard. Tradução: Mateus Araújo Silva. São Paulo: 
. 'Um 'Efeito Cinema' na Arte Contemporânea."Dispositivos de registro na arte contemporânea/ organização Luiz Cláudio da Costa. Rio de Janeiro: Editora Contra Capa, 2009.

Cinéma et art contemporain: vers un cinéma d'exposition?

De la migration d'un dispositif (ouvrage en préparation, version de travail) versão de trabalho gentilmente fornecida pelo autor durante palestra na ECA USP em 2013.

DUCHAMP, Marcel. "O ato criador". In: Gregory Battcock (org.). A nova arte. São Paulo: Perspectiva, 1975. p. 73-74

GONÇALVES, Osmar (Org.). Narrativa Sensoriais Ensaios sobre cinema e arte contemporânea. Rio de Janeiro: Editora circuito, 2014.

GOODING, Mel. Movto Arte Moderna - Arte Abstrata. Trad. Otacílio Nunes, Valter Ponte.

São Paulo: Cosac Naify, 2002

GORDON, Kelly. "Projections Dreams." IN: BROUHER, Kerry et al.(ORG.). The cinema Effect: Ilusion, reality, and the moving image. Smithsonian Hirshhorn Museum and Sculpture Garden, 2008. Disponível em: , < http://tonyoursler.com/files/HH-cinema-p1-176ad2\%208.28.07.pdf > Acesso: 21 de maio de 2014.

GROYS, Boris. Camaradas do tempo. Caderno SESC_Videobrasil, São Paulo, n,6,p. 119$127,2010$.

GULLAR, Ferreira. Etapas da arte contemporânea: do cubismo à arte neoconcreta. Rio de Janeiro: Revan, 1998.

HERKENHOFF, Paulo. "Rennó ou a beleza e o dulçor". In Rosângela Rennó. Edusp: São Paulo, 1996.

HUHTAMO, Erkki. Elements of Screenology: Toward an Archaeology of the Screen. Published in ICONICS: International Studies of the Modern Image, Vol.7 (2004), pp.3182.Tokyo: The Japan Society of Image Arts and Sciences.Disponível em: < http://gebseng.com/media_archeology/reading_materials/Erkki_Huhtamo

Elements_of_Screenology.pdf >

JANUSZCZAK, Waldemar. Técnicas de los Grandes Pintores. Madrid: H. Blume Ediciones, 1981.

JEVENOIS. Ana Villarquide: La pintura sobre tela I: Historiografía, técnicas y materiales, Vol. 1. Editorial Nerea, San Sebastián, 2004.

KAPROW, Alan. “O legado de Jackson Pollock.” Em: FERREIRA, Glória; COTRIM, Cecilia (orgs.) Escritos de artistas: anos 60/70. Rio de Janeiro: Jorge Zahar, 2006, pp 37- 45.

LEÃO, Lúcia (org). O chip e o caleidoscópio: reflexões sobre as novas mídias. São Paulo: Editora Senac, 2005 
Le Grice, Malcolm. Abstract film and beyond. Cambridge, MA: MIT Press, 1977.

MACHADO, Arlindo. A Arte do Vídeo. São Paulo: Editora brasiliense, 1988. Pré-cinemas\& pós-cinemas. São Paulo: Papirus, 1997

MACHADO, Arlindo (org.). Made in Brasil. Três décadas do vídeo brasileiro. São Paulo: Itaú Cultural, 2003.

Arte e mídia. Rio de Janeiro: Jorge Zahar, 2007

"O cinema e a condição pós-midiática." Em: MACIEL, Kátia (org.) Cinema sim: ensaios e reflexões. São Paulo: Itaú Cultural,2008, pp.64- 73.

(2012). "Cinema e arte contemporânea". Em: Revista Z CulturalPublicações-Ano VII- 01. Disponível em: < http://revistazcultural.pacc.ufrj.br/cinema-e-artecontemporanea-de-arlindo-machado/ > (Acesso em dez. de 2013).

- (2010). Pioneiros do vídeo e do cinema experimental na América Latina. Significação - Revista de Cultura Audiovisual, [S.1.], v. 37, n. 33, p. 21-40. ISSN 2316-7114.

Disponível em: < http://www.revistas.usp.br/significacao/article/view/68102/70660 > . Acesso em: 20 abril. 2014.

MACIEL, Kátia (org). Transcinemas. Rio de Janeiro: Contra Capa Livraria, 2009.

. "O cinema tem que virar instrumento". As experiências de quase-

cinema de Hélio Oitiica e Neville de almeida. Em MACIEL, Katia (org.). Transcinemas. Rio de Janeiro: Contra Capa Livraria, 2009.

"Entrevista de Neville de Almeida a Katia Maciel." Em MACIEL, Katia (org.). Transcinemas. Rio de Janeiro: Contra Capa Livraria, 2009.

MANNONI. Laurent. A grande arte da luz e da sombra: arqueologia do cinema. Tradução Assef Kfouri. São Paulo: Editora SENAC São Paulo: UNESP, 2003.

MANOVICH, Lev. The Language of New Media. Cambridge: MIT Press, 2001.

MARCHESSAULT, Janine. “ Multi- Screens and Future Cinema: The Labyrinth Project at Expo 67, In: MARCHESSAULT, Janine; LORD, Susan (edits). Fluid Screens, Expanded Cinema. Toronto, ON: University of Toronto Press, 2007, pp. 29-51. Disponível em:

$<$ http://books.google.com.br/books?id=W5vpaSh5PwIC\&printsec $=$ frontcover\&dq=Fluid+Scr eens,+Expanded+Cinema\&hl=en\&sa=X\&ei=VJGgU6CSH8_JsQTe0oL4Cg\&redir_esc=y\#v= onepage \&q\&f=false $>$ (Acesso em abril de 2014). 
MATTOS, A.C. Gomes de. Do cinetoscópio ao cinema digital: breve história do cinema americano. Rio de Janeiro: Rocco, 2006.

MELIM, Regina. Performance nas artes visuas. Rio de Janeiro: Jorge Zahar, 2008.

MELLO, Christine. Extremidades do Vídeo. São Paulo: Editora Senac, 2008.

MERCURIO, Gianni; PAPARONI, Demetrio. Tony Oursler Open Obscura. Catalogo della mostra (Milano, 18 marzo-12 giugno 2011) Disponível em: . < http://www.tonyoursler.com/files/OURSLER_IMP.pdf >(Acesso em 27 de abril de 2014).

MEUSY, Jean-Jacques . «La Polyvision, espoir oublié d'un cinéma nouveau », 1895. Mille huit cent quatre-vingt-quinze [En ligne], 31 | 2000, mis en ligne le 06 mars 2006, consulté le 30 abril de 2014.URL : http://1895.revues.org/68

MONDLOCH, Kate. Screens: viewing media installation art .London: University of Minnesota Press, 2010

MONTESINOS, Fernando. História Breve da Pintura Ocidental: Séculos XIV-XIX. Coimbra: Imprensa da Universidade, 2010.

MORATTI, Letizia. Apresentação do catálogo. Tony Oursler Open Obscura. Catalogo della mostra (Milano, 18 marzo-12 giugno 2011) Disppnível em: http://www.tonyoursler.com/files/OURSLER_IMP.pdf. Acesso em 27 de abril de 2014.

MUSSER, Charles. The emergence of cinema: The american screen to 1907. Nova York: Charles Scribner's Sons, 1994.

NERI, Louise. Smoke and Mirrors: tony Ousler"s Influence Machine. A conversation between tony Oursler and Louise Neri., 2001. Disponível em:

http://www.artangel.org.uk//projects/2000/the_influence_machine/smoke_and_mirrors_a_con versation/smoke_and_mirrors_a_conversation (acesso em 26/04/2014)

OUSLER, Tony. Proposal for Judy and installation at Salzberg Kunstverein. 1994.

Disponível em: http://tonyoursler.com/files/proposalforjudy.pdf (acesso em 28 de abril de 2014)

PAÏNI, Dominique. "Reflexões sobre o cinema exposto.” In: MACIEL, Kátia (Org). Cinema sim: narrativas e projeções. Catálogo de exposição. São Paulo, Itaú Cultural, 2008, p.26-36.

PARENTE. André. "A forma cinema: variações e rupturas". In: MACIEL, Katia (org.). Transcimemas, Rio de Janeiro: Contra Capa Livraria, 2009, pp. 23-47.

PARFAIT, Françoise. Vidéo: un art contemporain. Paris: Regard, 2001

PERLOFF, Marjorie. O momento Futurista: Avant-garde, avant-guerre, e a linguagem da Ruptura. Tradução de Sebastião Uchoa Leite. São Paulo: Editora da Universidade de São Paulo, 1993. 
RENAN, Sheldon. Uma Introdução ao Cinema Underground. Rio de Janeiro: Lidador, 1970.

RUBIN, Billy. Influence Machine.2014 Disponível em

http://tonyoursler.com/individual_text.php?navItem=text\&textId=82\&dateStr=Feb.\%2025,\% 202014\&subSection=Articles\&title=Influence\%20Machine, $\% 202000$ (Acesso em 10 de maio de 2014

RUSH, Michael. Novas mídias na arte contemporânea. Tradução Cássia Maria Nasser; revisão da tradução Marylene Pinto Michael. São Paulo: Martins Fontes, 2006.

SANTAELLA, Lucia. Cultura e artes do pós-humano: Da cultura das mídias à cibercultura. 3 ed. São Paulo: Paulus, 2008.

$2008 b$

Por que as comunicações e as artes estão convergindo? 3.ed. São Paulo: Paulus,

SANTAELLA, Lucia; NÖTH, Winfried. Imagem: Cognição, semiótica, mídia. São Paulo:

Iluminuras, 2008c.

SANTOS. José Juan. TONY OURSLER. El clavo en la cabeza / TONY OURSLER. Um prego na cabeça.Revista Dardo Magazine,n. 21, 2012. Disponível em: ) http://www.revistasculturalesiberoamericanas.com/revistas/132/dardo-magazine/num/21/)

SERRA, M.M; RAMEY, Katryn. "Eye / Body. The cinematic paintings of Carolee Schneemann. In SchBLAETZ, Robin (ed.). Women's Experimental Cinema: Critical Frameworks. Duke University Press, 2007

SHAW, Jeffrey. "O cinema digitalmente Expandido: o cinema DEPOIS fazer filme".In: LEÃO, Lúcia (org.) O chip e o caleidoscópio . Reflexões sobre as novas mídias. São Paulo: Editora Senac, 2005.

SPERLING, David. "Corpo + arte = Arquitetura. Proposições de Hélio Oiticica e Lygia Clark." Em: BRAGA, Paula (org.). Fios soltos: a arte de Hélio Oiticica. São Paulo: Perspectiva, 2008.

STANGOS, Nikos. Conceitos da arte moderna. Tradução Álvaro Cabral. Rio de Janeiro: Jorge Zahar, 1991.

SOGABE, Milton. Imagem Y Material. São Paulo, 1990. Dissertação (Mestrado em Comunicação e Semiótica) - Pontifícia Universidade Católica de São Paulo.

."Uma viagem da imagem pelo espaço.” In LEÃO, Lucia (Org.). Interlab: Labirintos do pensamento contemporâneo. São Paulo Fapesp: Iluminuras, 2002, pp. 125 -128.

STANTON, Jeffrey. Cinema Experimental Multi- Screen. Disponível em: http://www.westland.net/expo67/map-docs/cinema.htm, (Acesso em 09 de junho de 2014)

SUTTON, Gloria, "Stan VanDerBeek's Movie-Drome: Networking the subject," in: SHAW, Jeffrey; WEIBEL, Peter. Future Cinema: The Cinematic imaginary after film. London: MIT 
Press, 2003.

VENANCIO, Paulo Filho. Projetor: Tony Oursler. Coedição Automática Edições, 2011. (Catálogo da exposição realizada no Oi Futuro, no Rio de Janeiro, de 23 de novembro a 23 de janeiro de 2011).

VIEIRA, João Luiz. As vanguardas históricas: Eisenstein, Vertov e o construtivismo cinematográfico. In: BENTES, Ivana (Org), Ecos do cinema : de Lumière ao digital. Rio de Janeiro:Editora UFRJ, 2007,p.69-82.

WATCHEL, Edward. The first picture show: Cinematic aspects of cave art. Leonardo $\mathrm{n}^{\circ} 2$. San Francisco,1993.v.26

WEIBEL, Peter. "Teoria narrada: projeção múltipla e narração múltipla.” In: LEÃO, Lúcia (org.) O chip e o caleidoscópio . Reflexões sobre as novas mídias. São Paulo: Editora Senac, 2005.

'Expanded.Cinema, vídeo and virtual envirornments." IN: SHAW, Jeffrey and Peter Weibel. Future Cinema - The cinematic imaginary after the film, Mit Press, Mcambridge, 2003.

WODICZKO,Krzysztof,: Entrevistado por ART21. Krzysztof Wodiczko: "Hiroshima Projection" Disponível em: http://www.art21.org/texts/krzysztof-wodiczko/interview-krzysztofwodiczko-hiroshima-projection (Acesso em 30 de junho de 2013)

Press, 1999.

. Critical Vehicles: Writings, Projects, Interviews. Cambridge Mit

YOUNGBLOOD, Gene. Expanded Cinema. New York: P. Dutton \& Co.Inc. 1970. 


\section{APÊNDICE}

Em anexo a essa dissertação segue um DVD contendo os trabalhos de nossa autoria descritos no capítulo 3 no tópico 3.4 até o 3.4 .7

OBRAS:

1. Autorretrato com duração e sons variáveis I/ ano 2011 / Instalação Audiovisual

2. Autorretrato com duração e sons variáveis II / ano 2012/ Instalação Audiovisual

3. Autorretrato com duração e sons variáveis III / ano 2012/ Instalação Audiovisual

4. Autorretrato com duração e sons variáveis IV/ ano 2014/ Instalação Audiovisual

5. Janelas / vídeo/ 2011/ 11'16”

6. Sem Título I/ Vídeo/ ano 2011/ 05’00”

7. Sem Título II/ Vídeo/ano 2011/ 04’25"

8. Sem Título III/ Vídeo/ 2011/ 03'59”

9. Pintura em Atos/videoinstalação/ 2012/ 06'36" em looping. Registro da obra: 05'42”

10. Sem Título/ vídeo/ 03’46

11. Sem Título /ano 2012/videoinstalação /04'00” em looping 
